UNIVERSIDADE DE SÃO PAULO

INSTITUTO DE FÍSICA DE SÃO CARLOS

JOSÉ LUIZ DE SOUZA LOPES

Plantaricina 149 e análogos: atividade antimicrobiana, estudos estruturais e mecanismos de ação

São Carlos 

JOSÉ LUIZ DE SOUZA LOPES

Plantaricina 149 e análogos: atividade antimicrobiana, estudos estruturais

e mecanismos de ação

Tese apresentada ao Programa de Pós-Graduação em Física do Instituto de Física de São Carlos, da Universidade de São Paulo, para obtenção do título de Doutor em Ciências.

Área Física Aplicada - Opção Física Biomolecular. Orientadora: Profa. Dra. Leila Maria Beltramini

São Carlos 


\section{AUTORIZO A REPRODUÇÃO E DIVULGAÇÃO TOTAL OU PARCIAL DESTE TRABALHO, POR QUALQUER MEIO CONVENCIONAL OU ELETRÔNICO, PARA FINS DE ESTUDO E PESQUISA, DESDE QUE CITADA A FONTE.}

Ficha catalográfica elaborada pelo Serviço de Biblioteca e Informação IFSC/USP

Lopes, José Luiz de Souza

Plantaricina149 e análogos: atividade antimicrobiana, estudos estruturais e mecanismos de ação. / José Luiz de Souza Lopes; orientadora Leila Maria Beltramini. -- São Carlos, 2010.

225 p.

Tese (Doutorado - Programa de Pós-Graduação em Física - Área de concentração: Física Aplicada - Opção Biomolecular) - Instituto de Física de São Carlos da Universidade de São Paulo.

1 Peptídeo antimicrobiano. 2. Bacteriocinas. 3. Sistemas biomiméticos. 4. Interação peptídeo-lipídio. 5. Estudos espectroscópicos. I. Título. 


\section{FOLHA DE APROVAÇÃO}

José Luiz de Souza Lopes

Tese apresentada ao Instituto de Fisica de Sāo Carlos da Universidade de São Paulo para obtenção do título de Doutor em Ciências.

Área de Concentração: Física Aplicada Opçäo:Fisica Biomolecular.

Aprovado em: 19/03/2010

\section{Comissão Julgadora}

Prof. Dr. Clovis Ryuichi Nakaie

Instituiçāo: UFESP

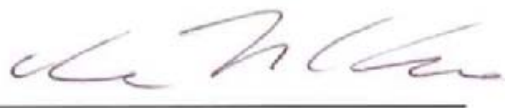

Profa. Dra. Rosangela Itri

Instituição: IF/USP

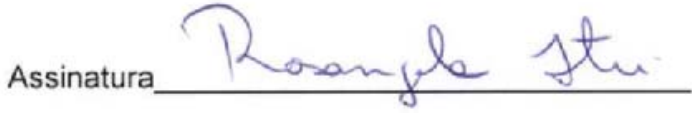

Profa. Dra. Ilana Lopes Baratella da Cunha Camargo

Instituiçāo: IFSC/USP

Assinatura_Im 6 BOCOMBGO

Prof. Dr. Eduardo Horjales Reboredo

Instituição: IFSC/USP

Assinatura

Profa. Dra.Leila Maria Beltramini

Instituição: IFSC/USP

Assinatura
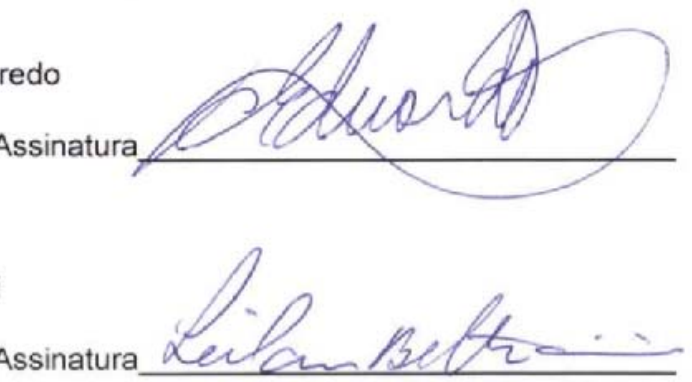

Aos meus pais, José Lopes e Maria das Dores Lopes, pela família e educação que me deram, e por estarem ao meu lado em todos os momentos. 



\section{AGRADECIMENTOS}

A Deus, por me fazer conhecer o seu amor, pelas grandes oportunidades a mim oferecidas e, principalmente, por estar comigo em todas elas;

À Prof. Dra. Leila Maria Beltramini, minha orientadora, grande amiga e incentivadora durante toda minha vida acadêmica e por ser a primeira a apostar que sempre seria capaz de aprender algo novo;

À Prof. Dra. Georgina Tonarelli da Universidade Nacional Del Litoral (Santa Fé-Argentina), por sua total disposição em me receber em seu laboratório, e em sua casa e por me tratar como um filho no período em que estive em seu país;

A Profa. Dra. Isabel Haro e a Prof. Dra. Maria José Gómara do CSIC-IQAC (BarcelonaEspanha), pela calorosa recepção em seu grupo de pesquisa, pelas idéias sugeridas neste trabalho e trocas de experiências em Barcelona;

A Profa. Dra. Vânia M. M. Melo da Universidade Federal do Ceará por sua simpatia, amizade e por aceitar colaborar neste trabalho;

Ao Prof. Josep Carrilla e a simpática técnica Amélia Lopez do Grupo de Calorimetria do CSIC-IIQAB, pela ajuda nos experimentos de DSC lá realizados;

A Profa. Dra. Rosangela Itri, pela parceria nos estudos de peptídeos antimicrobianos, e por nos permitir utilizar do seu laboratório em ensaios com vesículas gigantes;

A Profa. Dra. M. Elizabeth Zaniqueli, por abrir as portas do se laboratório e colaborar nos experimentos de tensão superficial;

À Prof. Dra. Nelma R.S. Bossolan, pelas conversas e discussões de experimentos de microscopia eletrônica;

Ao Prof Dr. José Cesar Rosa e sua orientanda Helen Julie Laure, pela prontidão em colaborar com os experimentos de espectrometria de massas;

Á Profa Dra. Heloisa S.S. Araujo, pelo seqüenciamento N-terminal dos peptídeos;

Á Profa Dra. Márcia Cominetti, pela colaboração com os ensaios de citotoxicidade; 
Aos amigos Álvaro Siano, Verónica Húmpola e Nathalia da Universidade Nacional Del Litoral (Santa Fé, Argentina), que me ajudaram nos meus primeiros passos de síntese dos peptídeos;

Aos amigos do Grupo de Química de Proteínas e Peptídos: Davi, Mari, Marisa, Jéssica, Emili, Josep Lluis, Elena, e em especial a Letícia pelas conversas e apoio durante o período em que estive em Barcelona;

Aos amigos do Programa Santander: Fabíola, Cibele, Alex, Adriano e Maria Angélica, pela convivência familiar e por todo apoio compartilhado;

A Pós-Doutoranda Thatyane M. Nobre pelas discussões, sugestões de experimentos, e total disposição para colaborar neste trabalho;

A M.Sc. Denise Hissa (UFC-Fortaleza), pelos ensinamentos da rotina em laboratório de Microbiologia e disposição em colaborar neste projeto;

Aos técnicos da Biofisica: minha mãezona Bel, por se fazer disponível em tudo e também por “puxar minha orelha” de vez em quando; Andressa, pela grande ajuda e iniciativa em operar novos equipamentos; e João, pela ajuda com os problemas de informática e equipamentos;

A todos os amigos do grupo de Biofisica Molecular Sérgio Mascarenhas do IFSC, pelas conversas formais e, principalmente, pelas informais;

Às sempre simpáticas funcionárias da biblioteca do IFSC-USP, que conseguem nos recebem com um sorriso enorme no rosto e nos orientam da melhor maneira;

À minha família, aos quais sempre recorro para todo e qualquer tipo de apoio;

A Pró-Reitoria de Pós-Graduação e ao Banco Santander, pela oportunidade de participar do Programa de Mobilidade Internacional de Pós-Graduandos, pelo apoio financeiro durante estágio em Barcelona;

Á Fundação de Amparo à Pesquisa do Estado de São Paulo (FAPESP) pela concessão da bolsa de doutorado e financiamento deste trabalho 



\section{RESUMO}

LOPES, J. L. S. Plantaricina149 e análogos: atividade antimicrobiana, estudos estruturais e mecanismos de ação. 2010. 225 p. Tese (Doutorado) - Instituto de Física de São Carlos, Universidade de São Paulo, São Carlos, 2010.

Peptídeos antimicrobianos são vistos como alternativas promissoras a serem empregadas pela indústria farmacêutica no controle de infecções causadas por microrganismos, como também na indústria alimentícia, onde podem desempenhar papéis como conservantes naturais de alimentos. Plantaricina149 é um membro deste grupo, composto por 22 resíduos de aminoácidos, com natureza catiônica e atividade inibitória sobre algumas bactérias patogênicas. Neste trabalho, foram sintetizados diferentes peptídeos análogos à Plantaricina149 para investigar suas ações sobre microrganismos (bactérias e fungos), a fim de correlacionar estes estudos com a ação lítica do peptídeo em modelos de membrana diversos (monocamadas e vesículas fosfolipídicas). A interação de Plantaricina149 com estes sistemas foi monitorada pelas espectroscopias de dicroísmo circular e fluorescência, ensaios de tensão superficial, calorimetria e ressonância plasmônica de superfície, e mostrou ser altamente específica para superfícies fosfolipídicas que apresentam densidade de cargas negativas, tais como a membrana celular de bactérias. A interação eletrostática inicial que se estabelece entre o peptídeo e os fosfolipídios é de extrema importância, sendo capaz de induzir uma estruturação helicoidal na região C-terminal do peptídeo, enquanto a região Nterminal contribui com as interações hidrofóbicas necessárias para a penetração do peptídeo nas camadas fosfolipídicas levando a ruptura das mesmas. De forma semelhante, a atividade antimicrobiana de Plantaricina149a (e alguns de seus análogos) também mostrou ser resultado das interações das duas regiões da molécula, e foi afetada com a retirada ou modificação da região N-terminal do peptídeo. Com a deleção desta região, o peptídeo passou a ter somente ação bacteriostática sobre Staphylococcus aureus e Pseudomonas aeruginosa, perdendo a capacidade bactericida.

Palavras-chave: Peptídeo antimicrobiano. Bacteriocinas. Sistemas biomiméticos. Interação peptídeo-lipídio. Estudos espectroscópicos. 



\begin{abstract}
LOPES, J. L. S. Plantaricin149 and analogs: antimicrobial activity, structural studies and mechanisms of action. 2010. 225 p. Thesis (Doctoral) - Institute of Physics of São Carlos, University of São Paulo, São Carlos, 2010.

Antimicrobial peptides are seen as promising alternatives to be employed in pharmaceutical industry for controlling infections caused by microorganisms, and also in food industry, where they can play roles as natural food preservatives. Plantaricina149 is a member of this group, constituted of 22 amino acid residues, cationic in nature and presenting inhibitory activity against some pathogenic bacteria. In this work, different Plantaricina149 analog peptides were synthesized to investigate their action against microorganisms (bacteria and fungi), with the aim of correlating these studies with the lytic action of the peptide on several membrane models (phospholipid monolayers and vesicles). The Plantaricina149 interaction with these systems was monitored by circular dichroism and fluorescence spectroscopies, surface tension assays, calorimetry and surface plasmon resonance, and showed to be highly specific to phospholipid surfaces that present negative charge density, such as the bacteria cell membrane. The initial peptide-phospholipids electrostatic interaction is extremely important, and it is capable of inducing a helical structure in the peptide C-terminal region, while the $\mathrm{N}$ terminal region contributes with the hydrophobic interactions needed to the peptide penetration in the phospholipid layers and to the disruption of them. Similarly, the Plantaricina149 antimicrobial activity has also proved to be a result of the interactions from the two regions of the molecule, and it was strongly affected by the removal or modification of the peptide N-terminal region. Promoting the deletion of this region has left the peptide only with a bacteriostatic action against Staphylococcus aureus and Pseudomonas aeruginosa, removing its bactericide ability.
\end{abstract}

Keyword: Antimicrobial peptide. Bacteriocins. Biomimetic systems. Peptide-lipid interaction. Spectroscopic studies. 



\section{LISTA DE ILUSTRAÇÕES}

Figura 1 - Protetores temporários da química de Fmoc e Boc $\quad 50$

Figura 2 - Esquema dos ciclos de reação de síntese de peptídeos $\quad 51$

Figura 3 - $\quad$ Esquema de SPPS com a estratégia de Fmoc 52

Figura 4 - $\quad$ Espectro de CD de vários tipos de estrutura secundária $\quad 68$

$\begin{array}{lll}\text { Figura } 5 \text { - } \quad \text { Imagem em tempo real da gota pendente } & 78\end{array}$

Figura 6 - Reflexão total interna e SPR em sistema BIACORE $\quad 80$

Figura 7 - $\quad$ Imobilização de fosfolipídios nos chips HPA e L1 82

Figura 8 - $\quad$ Ensaio colorimétrico de Kaiser $\quad 89$

Figura 9 - $\quad$ Espectro de massas de Pln149a 95

Figura 10 - $\quad$ Espectros de massas de Pln149S, Pln149W e Pln149WS 96

Figura 11 - Espectros de massas dos peptídeos com modificações no N-

$\begin{array}{ll}\text { terminal } & 97\end{array}$

Figura 12 - Perfil cromatográfico da eluição dos peptídeos em coluna $C_{18}$. 99

Figura 13 - Estrutura química dos aminoácidos Serina e Tirosina $\quad 101$

Figura 14 - Atividade hemolítica de Pln149a e peptídeos análogos $\quad 103$

Figura 15 - Ensaio antibiograma realizado com Pln149a e Pln149S sobre diferentes microorganismos

Figura 16 - Curvas de crescimento de S.aureus $\quad 106$

$\begin{array}{lll}\text { Figura } 17 \text { - } \quad \text { Curvas de crescimento de P.aeruginosa } & 106\end{array}$

Figura 18 - Subcultivo dos poços do ensaio de MIC $\quad 107$ 
Figura 19 - Curvas de crescimento de C.albicans

Figura 20 - Curvas de crescimento de Lactobacillus L18. 109

$\begin{array}{llr}\text { Figura } 21 \text { - } \quad \text { Curvas de crescimento de Saureus } & 110\end{array}$

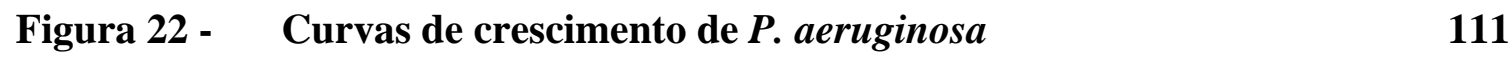

Figura 23 - Subcultivo dos poços do ensaio de MIC 112

Figura 24 - Ensaio de inibição do crescimento de Saccharomyces cerevisiae 113

Figura 25 - Imagens de microscopia eletrônica de varredura sobre células de S.cerevisiae crescidas na ausência e na presença de Pln149a 115

Figura 26 - Ensaio de citotoxicidade em células de câncer de próstata da linhagem DU-145

Figura 27 - Espectro de CD no UV distante de Pln149a e dos peptídeos modificados

Figura 28 - Espectros de CD de Pln149a com diferentes composições de metanol

Figura 29 - Pln149a na presença de diferentes carboidratos

Figura 30 - Espectro de CD da interação de Pln149a com diferentes LUVs

Figura 31 - Espectro de CD da interação dos peptídeos análogos de Pln149 com LUVs de DPPC

Figura 32 - Espectro de CD da interação dos peptídeos análogos de Pln149 com LUVs de DPPG.

Figura 33 - Tratamento de pH em Pln149a antes e durante sua interação com LUVs de DPPG

Figura 34 - Espectros de CD de Pln149a frente a variações de força iônica antes e durante sua interação com LUVs de DPPG. 
Figura 35 - Pln149a na presença de vesículas mistas de DPPC/DPPG em diferentes razões molares

Figura 36 - Pln149S na presença de vesículas mistas de DPPC/DPPG em diferentes razões molares

Figura 37 - Espectro de CD de Pln149a na presença de vesículas de Leishmania

Figura 38 - Espectro de CD de Pln149a em diferentes concentrações

Figura 39 - Espectros de emissão de fluorescência de Pln149a e formas modificadas

Figura 40 - Espectros de emissão de fluorescência de Pln149a em concentrações crescentes de $\mathrm{KH}_{2} \mathrm{PO}_{4}$

Figura 41 - Espectro de emissão de fluorescencia da interação de Pln149a com LUVs

Figura 42 - Espectrs de fluorescencia da interação dos peptídeos análogos a Pln149a com LUVs de DPPC e DPPG

Figura 43 - Liberação dos conteúdos vesiculares em lipossomos de DPPG

Figura 44 - Comparação da fração de ANS liberado pelos lipossomos de DPPG pela ação de Pln149a e Pln149S

Figura 45 - L Liberação dos conteúdos vesiculares em lipossomos de POPG

Figura 46 - Fração de ANS liberado pelos lipossomos de POPG pela ação dos peptídeos

Figura 47 - Liberação dos conteúdos vesiculares em vesículas mistas de DPPC/DPPG (1:1) pela ação de Pln149a

Figura 48 - Leakage em lipossomos de DPPG/DPPC (1:1) pela ação de Pln149a 
Figura 49 - Espectros de fluorescência de Pln149W e Pln149WS na ausência e na presença de LUVs de DPPG

Figura 50 - $\quad$ Ajuste experimental das emissões em 350 nm de Pln149W(A) e Pln149WS(B) na titulação com DPPG

Figura 51 - Diagrama de Hidrofilicidade de Pln149a

Figura 52 - Projeções helicoidais dos peptídeos sintetizados

Figura 53 - Medida da tensão superficial de Pln149a solução aquosa

Figura 54 - Medidas da tensão superficial de Pln149a em monocamadas de DPPG

Figura 55 - Comportamento dos valores da elasticidade superficial de Pln149a em monocamadas de DPPG

Figura 56 - Cinética de adsorção de Pln149a em monocamadas mistas de DPPC/DPPG (A), valores da elasticidade superficial (B) e variação dos valores de elasticidade superficial (C)

Figura 57 - Sensorgrama da imobilização de uma monocamada de DPPG sobre o sensorchip HPA

Figura 58 - $\quad$ Sensorgramas da interação de Pln149a com monocamada de DPPG

Figura 59 - Sensorgrama da imobilização de uma bicamada de DPPG sobre o sensorchip L1

Figura 60 - Sensorgramas da interação de Pln149a com a bicamada de DPPG

Figura 61 - Curvas termodinâmicas da interação de Pln149a e Pln149S com vesículas de DPPG nas diferentes razões molares 
Figura 62 - Dependência dos parâmetros termodinâmicos de $-\Delta T, \Delta H$ e 166 Tm das vesículas fosfolipídicas de DPPG

Figura 63 - Medida da entalpia de ligação de Pln149a nas vesículas de DPPG

Figura 64 - Medida da entalpia de ligação de Pln149S nas vesículas de DPPG

Figura 65 - Modelo criado para a estrutura tridimensional de Pln149a

Figura 66 - Modelo criado para o mecanismo de ação de Pln149a durante sua interação com fosfolipídios negativos 



\section{LISTA DE TABELAS}

Tabela 1 - Origem e sequencia primaria de alguns dos AMPs mais conhecidos

Tabela 2 - Tabela 2: Uso de AMP em produtos alimentícios

Tabela 3 - Tabela 3 - Bacteriocinas produzidas por L. plantarum

Tabela 4 - Nome e seqüência dos peptídeos sintetizados

Tabela 5 - $\quad$ Roteiro de síntese dos peptídeos do Grupos I, II e III

Tabela 6 - Rendimento e propriedades dos peptídeos sintetizados

Tabela 7 - Tempo de eluição e hidrofobicidade dos peptídeos sintetizados

Tabela 8 - Conteúdos de estrutura secundária dos peptídeos em solução aquosa

Tabela 9 - Fração helicoidal de Pln149a e Pln149S incubados com LUVs mistas de DPPG/DPPG

Tabela 10 - Fração de peptídeo ligada a superfície dos lipossomos

Tabela 11 - Parâmetros termodinâmicos da interação dos peptídeos com DPPG 



\section{LISTA DE ABREVIATURAS}

aa

$\lambda$

ACN

ANTS

BLAST

Boc

CD

D.O.

DCM

DIEA

DLPC

DMF

DMPE

DPPC

DPPE

DPPG

DPPS

DPX

DSC

EDT

ESI-MS

Fmoc

HATU

HBTU

HEPES

HOBt

HPLC

ITC

aminoácido

Comprimento de onda

Acetonitrila

Ácido 8-aminonaftaleno-1,3,6,-trisulfonico

Basic Local Alignment Search Tool

terc-Butiloxicarbonila

Circular Dichroism, dicroísmo circular

Densidade Ótica

Diclorometano

N- Diisopropiletilamina

Dilaurilfosfatidilcolina

N,N-Dimetilformamida

Dimiristoilfosfatidiletanolamina

Dipalmitoilfosfatidilcolina

Dipalmitoilfosfatidiletanolamina

Dipalmitoilfosfatidilglicerol

Dipalmitoilfosfatidilserina

N,N'-p-xilenobis (brometo de piridineo)

Differential Scanning Calorimetry, Calorimetria de Varredura diferencial

1,2-Etanoditiol

Electros Spray Ionization - Mass Spectrometry, Espectrometria de massa por ionização etéctron-spray

9-Fluorenilmetiloxicarbonila

Hexafluoroborato de O-(1H-Benzotriazol-1-il)-

$\mathrm{N}, \mathrm{N}, \mathrm{N}^{\prime}, \mathrm{N}^{\prime}$-tetrametiluronio

Hexafluoroborato de O-(1H-Benzotriazol-1-il)-

$\mathrm{N}, \mathrm{N}, \mathrm{N}^{\prime}, \mathrm{N}^{\prime}$-tetrametiluronio

Ácido N-(2-hidroxietil)piperacina-N'-(2-etanosulfônico)

N-Hidroxibenzotriazol

High performance liquid chromatography, cromatografia líquida de alto desempenho

Isothermal Titration Calorimetry, Calorimetria de titulação isotérmica 


\begin{tabular}{|c|c|}
\hline LUV & $\begin{array}{l}\text { Large Unilamellar Vesicles, Vesículas unilamelares } \\
\text { grandes }\end{array}$ \\
\hline $\mathbf{m} / \mathbf{z}$ & Massa por carga \\
\hline MIC & Concentração inibitória mínima \\
\hline NCBI & National Center for Biotechnology Information \\
\hline PBS & Phosphate Buffer Saline, tampão fosfato salino \\
\hline pI & Ponto isoelétrico \\
\hline POPG & Palmitoil-Oleoilfosfatidilglicerol \\
\hline RU & Unidades de Ressonância \\
\hline SDS-PAGE & $\begin{array}{l}\text { Sodium DodecylSulphate - Polyacrilamide Gel } \\
\text { Electrophpresis, eletroforese em gel de poliacrilamida- } \\
\text { SDS }\end{array}$ \\
\hline $\begin{array}{l}\text { SELCON, Continll e } \\
\text { CDSSTR }\end{array}$ & $\begin{array}{l}\text { Programas de análise de espectros de CD que estimam o } \\
\text { conteúdo de estrutura secundária de uma proteína }\end{array}$ \\
\hline SPR & $\begin{array}{l}\text { Surface Plasmon Ressonance, Ressonância Plasmônica } \\
\text { de Superfície }\end{array}$ \\
\hline SUV & $\begin{array}{l}\text { Small Unilamellar Vesicles, Vesiculas unilamelares } \\
\text { pequena }\end{array}$ \\
\hline TBTU & $\begin{array}{l}\text { 2-(1H-Benzotriazol-1-il)-1,1,3,3-tetrametilurônio } \\
\text { tetrafluoroborato }\end{array}$ \\
\hline TFA & Ácido trifluoroacético \\
\hline TIS & Triisopropilsilano \\
\hline u.a. & Unidade arbitrária \\
\hline UV & Ultravioleta \\
\hline
\end{tabular}




\section{LISTA DE SIGLAS}

\section{Símbolo dos aminoácidos}

Código de 3 letras Código de 1 letra

Ala

Arg

Asn

Asp

Cys

Gln

Glu

Gly

His

Iso

Leu

Lys

Met

Phe

Pro

Ser

Thr

Trp

Tyr

Val
A

$\mathbf{R}$

$\mathbf{N}$

D

C

Q

E

G

H

I

L

K

M

F

P

S

T

W

Y

V
Nome

Alanina

Arginina

Asparagina

Aspartato

Cisteína

Glutamina

Glutamato

Glicina

Histidina

Isoleucina

Leucina

Lisina

Metionina

Fenilalanina

Prolina

Serina

Treonina

Triptofano

Tirosina

Valina 



\section{SUMÁRIO}

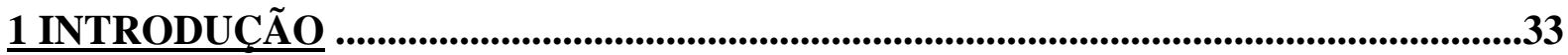

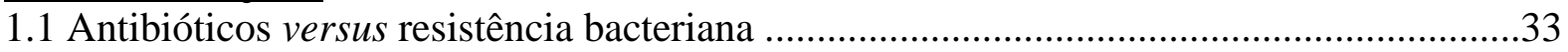

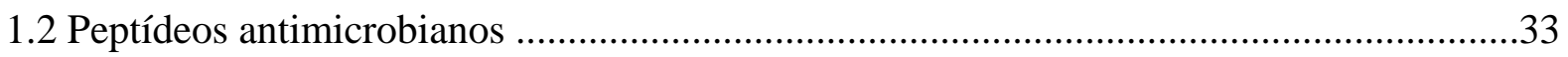

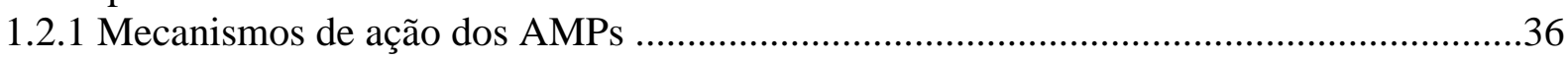

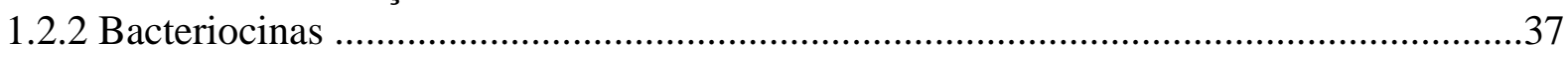

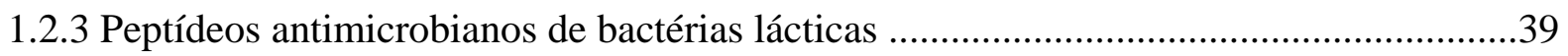

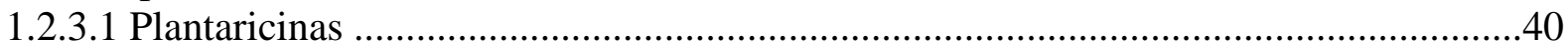

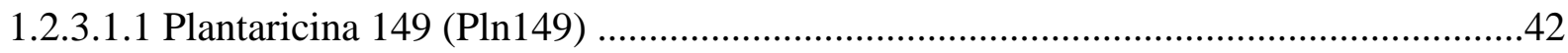

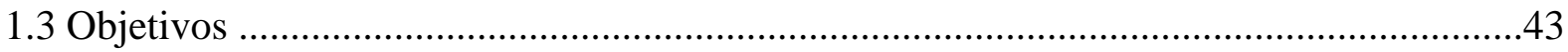

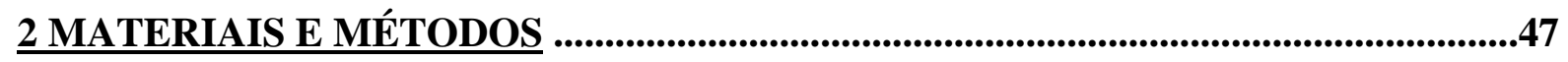

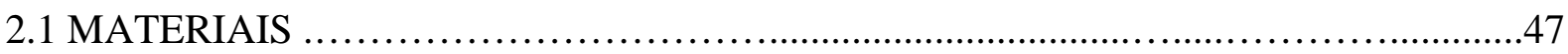

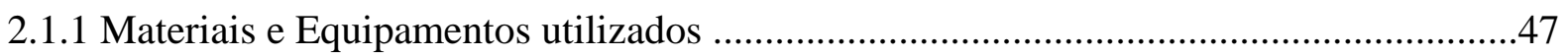

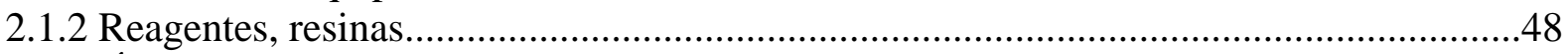

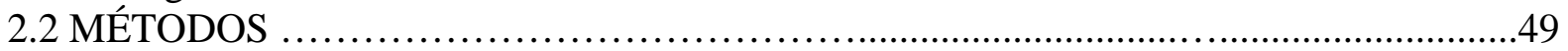

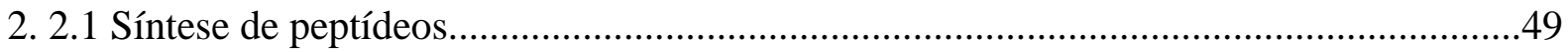

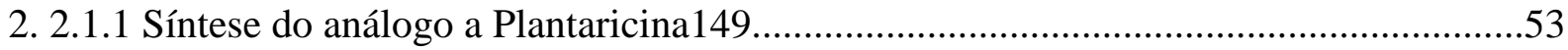

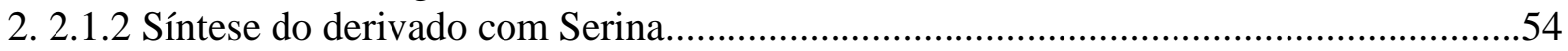

2. 2.1.3 Síntese dos derivados com modificações no N-terminal.........................................55

2. 2.1.4 Síntese dos derivados com Triptofano...................................................................56

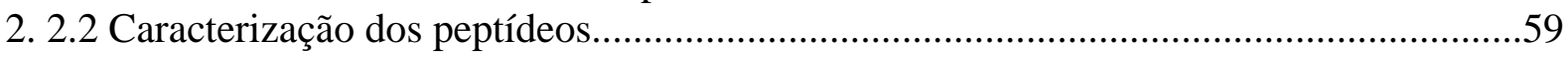

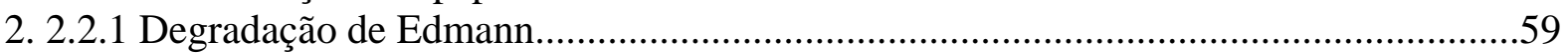

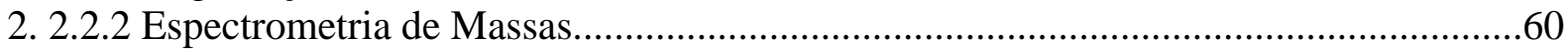

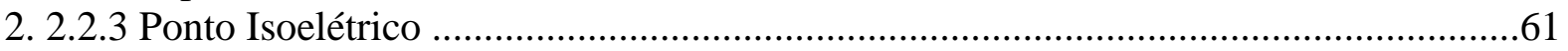

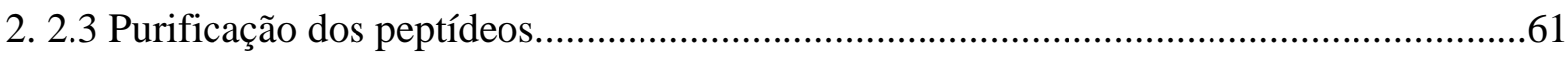

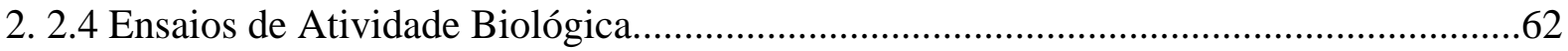

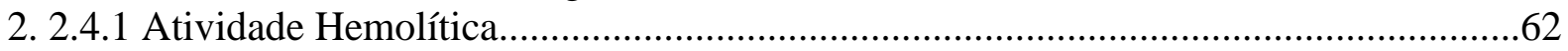

2. 2.4.2 Inibição do crescimento de microorganismos..............................................................63

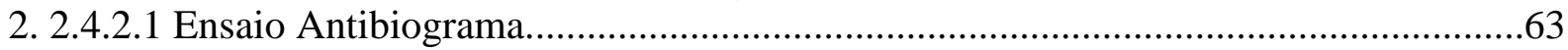

2. 2.4.2.2 Determinação da Concentração Inibitória Mínima (MIC) ........................................64

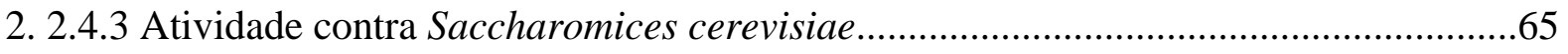

2. 2.4.3.1 Microscopia Eletrônica de Varredura.....................................................................65

2. 2.4.4 Inibição do crescimento de células tumorais .........................................................66

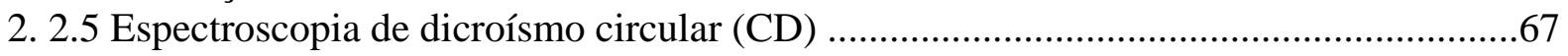

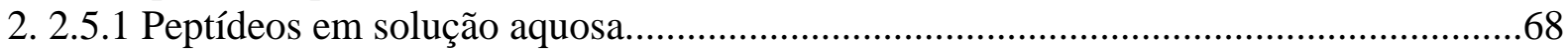

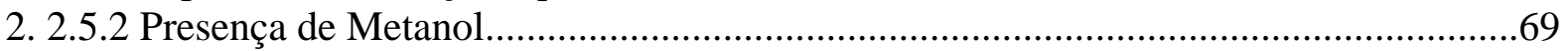

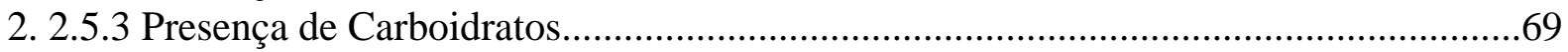

2. 2.5.4 Presença de vesículas fosfolipídicas.............................................................................70

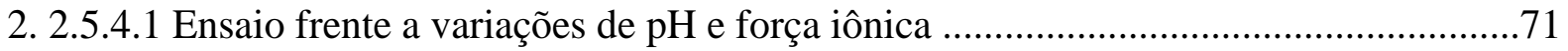

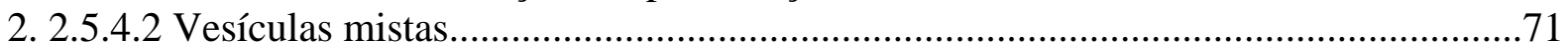

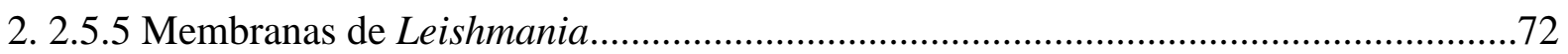

2. 2.5.6 Dependência com a concentração de peptídeo.........................................................72

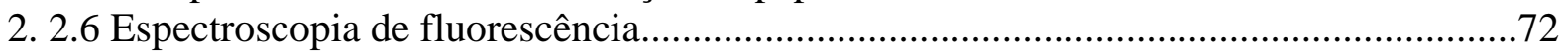

2. 2.6.1 Peptídeos em solução aquosa......................................................................................73 


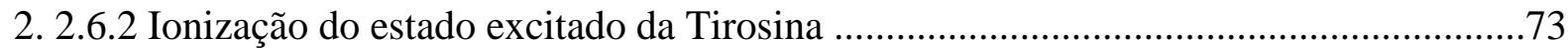

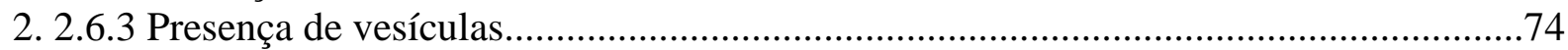

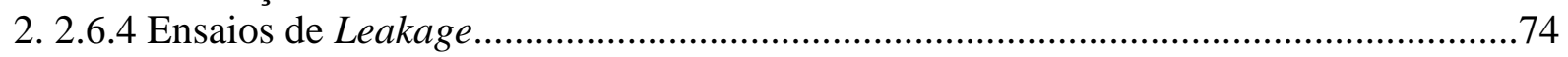

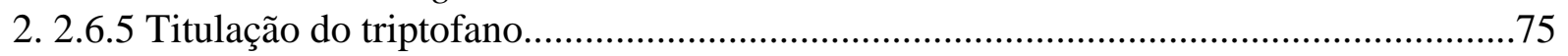

2. 2.7 Estudos de projeção em estrutura helicoidal..............................................................77

2. 2.8 Estudos de Tensão Superficial e Elasticidade..............................................................77

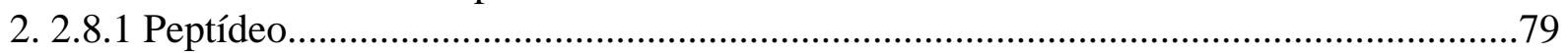

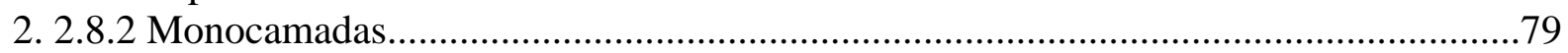

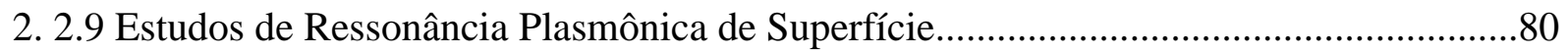

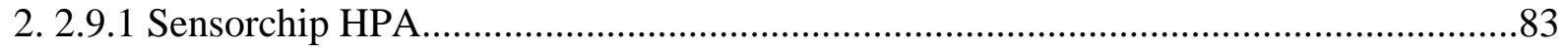

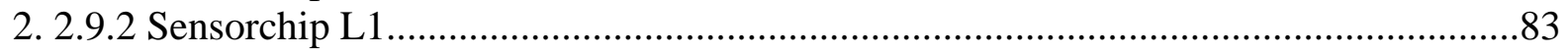

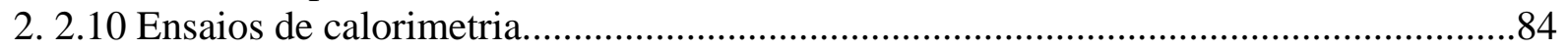

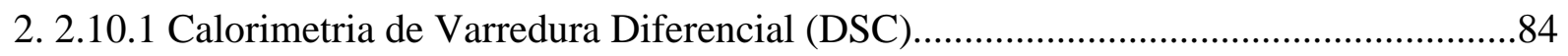

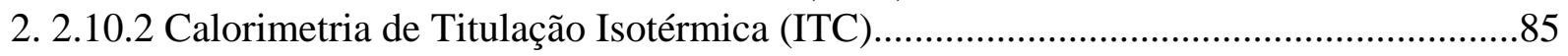

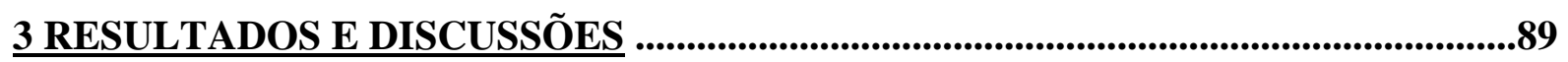

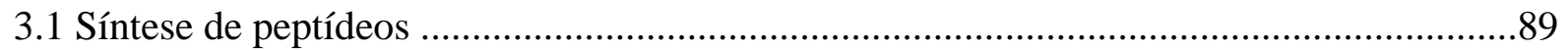

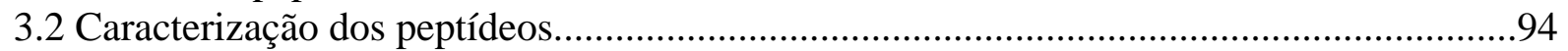

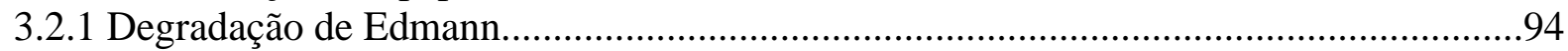

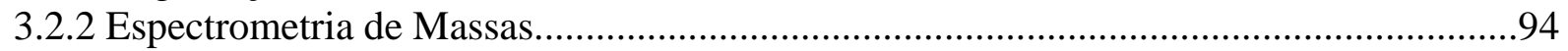

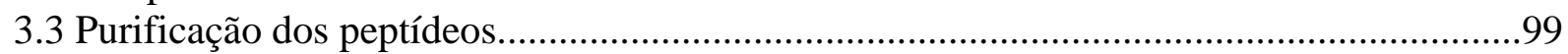

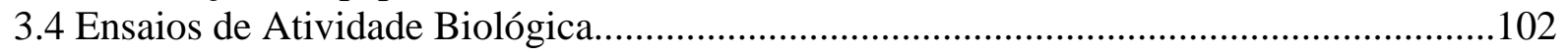

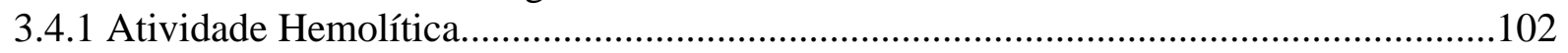

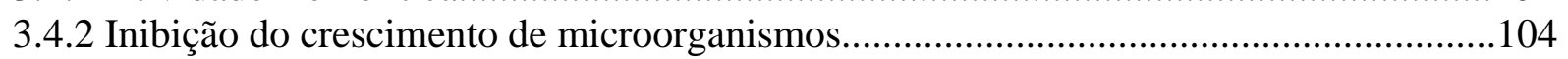

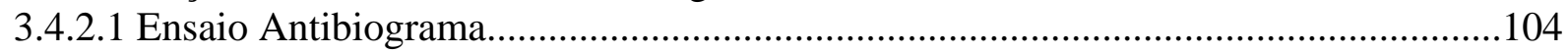

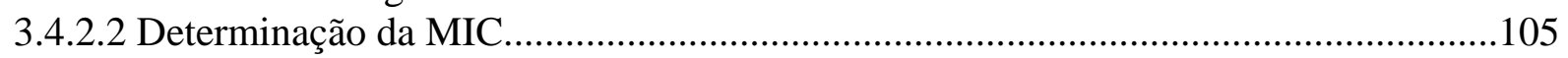

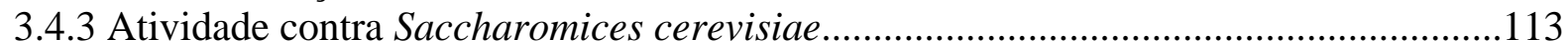

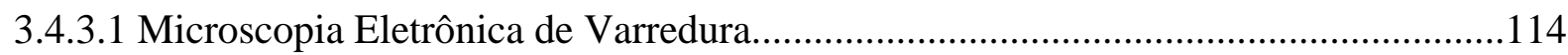

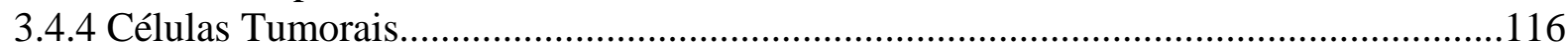

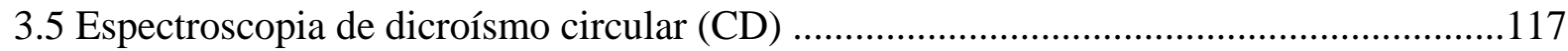

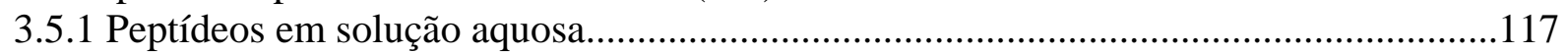

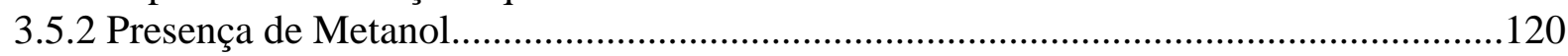

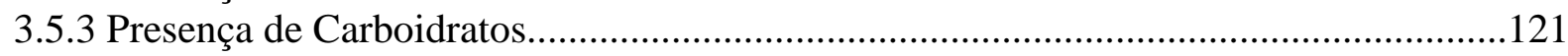

3.5.4 Presença de vesículas fosfolipídicas.......................................................................122

3.5.4.1 Ensaio frente a variações de pH e força iônica........................................................128

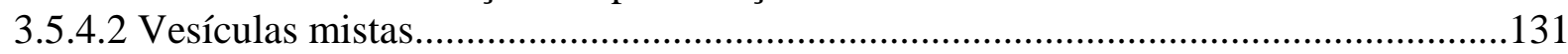

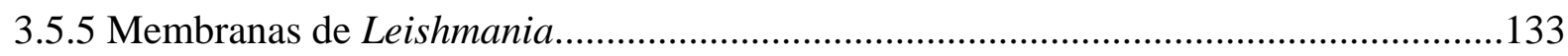

3.5.6 Dependencia com a concentração de peptídeo..........................................................134

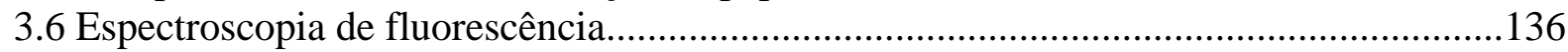

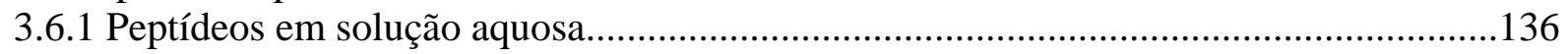

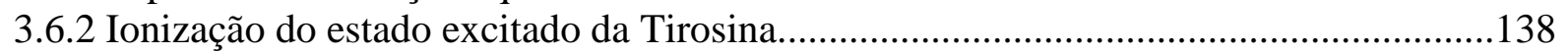

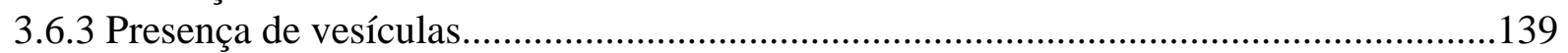

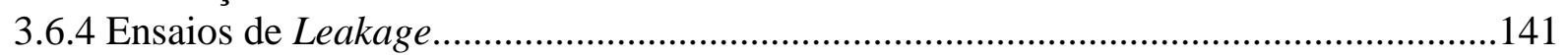

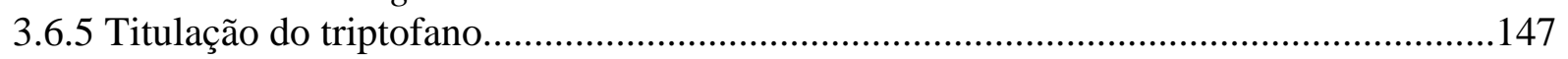

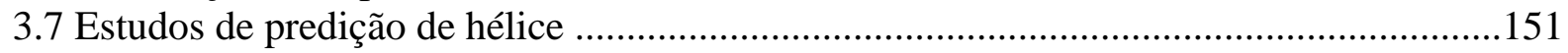

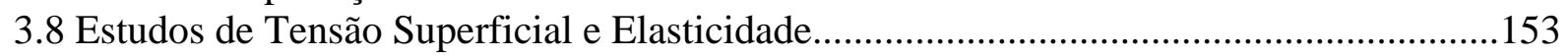

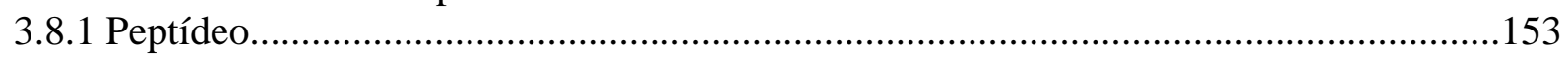

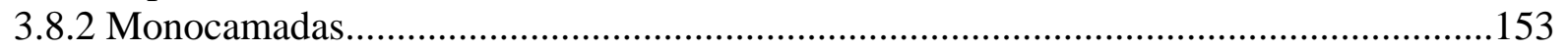




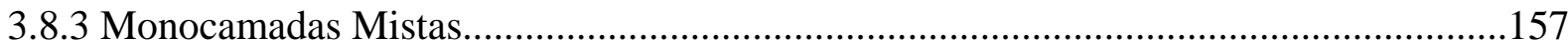

3.9 Estudos de Ressonância Plasmônica de Superfície........................................................158

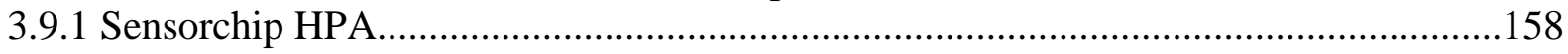

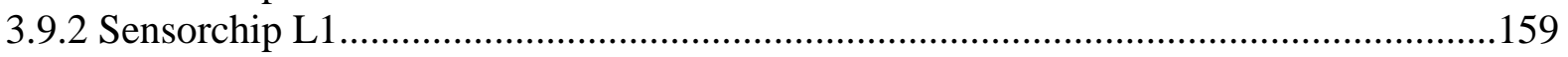

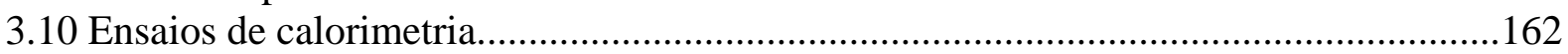

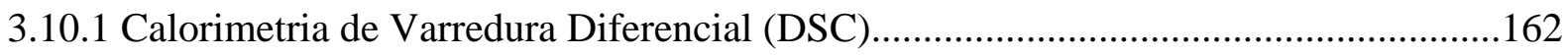

3.10.2 Calorimetria de Titulação Isotérmica (ITC) ….......................................................167

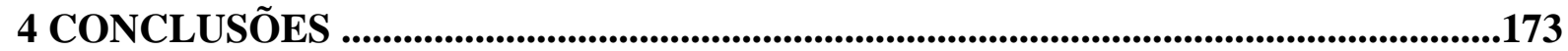

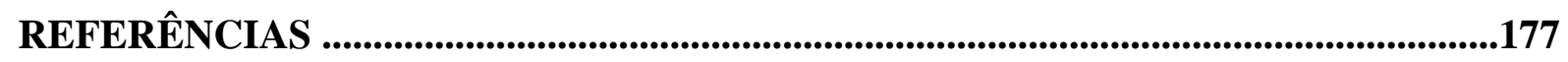

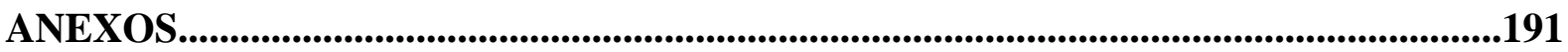






\section{INTRODUCÃ̃O}

\subsection{Antibióticos versus resistência bacteriana}

Até a primeira metade do século XX, muitos dos casos de infecções bacterianas estavam acometidos a altas taxas de mortalidade, pois escassas eram as alternativas de terapia médica. A descoberta dos antibióticos (1) e o desenvolvimento destas moléculas revolucionaram completamente a história da medicina, de modo que, atualmente, existe um grande arsenal disponível desses fármacos antimicrobianos.

Em contrapartida, devido à grande expansão desta terapia, o uso contínuo de antibióticos no mundo todo, associado às condições de higiene e saneamento, selecionaram microrganismos resistentes a alguns destes fármacos, desenvolvendo os casos de multiresistência bacteriana, no qual um grande número dessas novas cepas patogênicas teve sua procriação dentro dos próprios hospitais (2).

Isto aumentou consideravelmente o custo do tratamento das infecções e fez com que a taxa de mortalidade devido a doenças infecciosas voltasse a crescer nas últimas décadas. Surgiu, então a urgente necessidade do desenvolvimento de novas estratégias para o controle dessas enfermidades, seja pela descoberta constante de moléculas mais eficazes, ou pela intensificação na busca por antibióticos sintéticos alternativos e/ou fármacos de fontes naturais, a fim de substituir os antibióticos convencionais ou serem usados de modo complementar $(3,4)$. Essa busca motivou o interesse e os estudos num grupo de peptídeos que apresentam propriedades inibitórias frente ao crescimento de alguns microrganismos, tais moléculas são chamadas de peptídeos antimicrobianos (AMPs).

\subsection{Peptídeos antimicrobianos}

Os peptídeos, de um modo geral, tornaram-se uma classe de moléculas de crescente importância em bioquímica, química medicinal e fisiologia. Muitos peptídeos naturais 
possuem diversas funções fisiológicas importantes, como hormonal, neurotransmissores, citocinas e fatores de crescimento (5).

A descoberta de um grupo de polipeptídeos catiônicos, relativamente pequenos, contendo da por volta de 12 a 100 resíduos de aminoácidos (6), capazes de inibir o crescimento de microorganismos, firmou-se como uma das alternativas atualmente empregadas na luta contra as infecções (7).

Peptídeos antimicrobianos nativos estão largamente distribuídos entre os organismos, sendo encontrados em toda a escala evolutiva, desde procariontes até animais superiores como mamíferos (8). Estes peptídeos são produzidos como parte do sistema de defesa, onde desempenham um papel fundamental na sobrevivência do próprio organismo (9), atuando como uma das primeiras formas de defesa química das células eucarióticas contra invasão por outro organismo vivo no combate das infecções (10).

A expressão de um AMP pode ser constitutiva ou também induzida por um estímulo infeccioso e/ou inflamatório. Nesse ultimo caso, a transcrição é iniciada a partir da invasão do patógeno. Após a tradução da molécula, o peptídeo passa por diferentes processos que envolvem modificações pós-traducionais, tais como a clivagem de uma proteína precursora, amidação do C-terminal, e/ou formação de ponte dissulfeto (4).

Alguns dos AMPs conhecidos apresentam espectro de ação contra microorganismos patogênicos, tais como: Staphylococcus aureus, Listeria monocytogenes, Escherichia coli, Salmonella sp, Shigella sp, Vibrio cholerae, Pseudomonas sp, Bacillus cereus, Bacillus megaterium, Bacillus subtilis, Clostridium tyrobutyricum, Clostridium sporogenes, e outros.

Mais de 957 peptídeos diferentes com atividade antimicrobiana já foram identificados em diversos organismos $(3,11)$ e muitos deles isolados e caracterizados, incluindo a classe das cecropinas, identificadas em suínos (12), cujo importante representante é a melitina (13), a classe das magaininas, grupo de peptídeos que foram descobertas na glândula granular do epitélio da rã africana Xenopus laevis (9,14-16); as catelicidinas, isoladas de vertebrados, e que apresentam um segmento N-terminal bem conservado que é clivado proteoliticamente para gerar o peptídeo ativo; e as defensinas, grupo de peptídeos cíclicos em mamíferos $(17,18)$ e também em invertebrados $(6)$.

A Tabela 1 apresenta alguns dos AMPs mais conhecidos, bem como sua origem e estrutura primaria.

Alguns AMPs apresentam baixa seletividade para bactérias, sendo também tóxicos para células eucarióticas. Já outros, não apresentam atividade hemolítica em concentrações que atuam como potentes agentes antimicrobianos. Deste modo, o entendimento dos fatores que 
governam a seletividade dos AMPs aos seus alvos é crucial para o desenvolvimento de fármacos baseados nessas moléculas (3). A seletividade dos AMPs parece estar relacionada às diferentes composições lipídicas e às cargas presentes nas membranas externas das células procarióticas e eucarióticas (19).

Tabela 1 - Origem e sequencia primária de alguns dos AMPs mais conhecidos. Fonte: $(3,16,20)$.

\begin{tabular}{lll}
\hline Peptídeo & Origem & Sequencia \\
\hline Bombolitina I & Inseto & IKITTMLAKLGKVLAHV \\
Buforina II & Anfíbio & TRSSRAGLQFPVGRVHRLLRK \\
Cecropina A & Inseto & KWKLFKKIEKVGQNIRDGIIKAGPAVAVVGQATQIAK \\
Cecropina B2 & Inseto & RWKIFKKIEKMGRNIRDGIVKAGPAIEVLGSAKAI \\
Cecropina P1 & Suina & SWLSKTAKKLENSAKKRISEGIAIAIQGGPR \\
Ceratotoxina A & Inseto & SIGSALKKALPVAKKIGKIALPIAKAALPVAAGLVG \\
Crabrolina & Inseto & FLPLILRKIVTAL \\
Dermaseptin b & Anfíbio & DVLKKIGTVALHAGKAALGAVADTISQ \\
Dermaseptina B & Anfíbio & AMWKDVLKKIGTVALHAGKAALGAVADTISQ \\
Dermaseptina S & Anfíbio & ALWKTMLKKLGTMALHAGKAALGAAADTISQGTQ \\
Magainina 1 & Anfíbio & GIGKFLHSAGKFGKAFVGEIMKS \\
Magainina 2 & Anfíbio & GIGKFLHSAKKFGKAFVGEIMNS \\
Mastoparana & Inseto & INLKALAALAKKIL \\
Melittina & Inseto & GIGAVLKVLTTGLPALISWIKRKRQQ \\
Pardaxina & Peixe & GFFALIPKIISSPLFKTLLSAVGSALSSSGGQE \\
PGLa & Anfíbio & GMASKAGAIAGKIAKVALKAL \\
Temporina L & Anfíbio & FVQWFSKFLGRIL \\
Histatina 5s & Homem & DSHAKRHHGYKRKFHEKHHSHRGY \\
\hline
\end{tabular}

Algumas das estratégias para a otimização de AMPs, no sentido de torná-los mais estáveis e/ou ativos que a sua versão nativa, são o desenho e a síntese química de análogos e de peptídeos quiméricos. A síntese de análogos (de diferentes tamanhos e/ou substituições) 
contribui com valiosas informações sobre o mecanismo de ação, tanto sobre as regiões que teriam maior relevância na atividade antibacteriana, como aquelas que se ligariam nas membranas lipídicas; enquanto a síntese de peptídeos quiméricos, contendo partes de dois ou mais peptídeos com propriedades antibióticas diferentes, representam uma maneira de otimizar a ação destes num espectro mais amplo de microorganismos.

Além do seu apelo farmacológico, é de se ressaltar que os AMPs também são vistos como alvos promissores na industria alimentícia, uma vez que a segurança nos produtos alimentícios se tornou uma crescente preocupação internacional, e estas moléculas podem ser utilizadas como conservantes de alimentos (21).

Geralmente, conservantes químicos artificiais são utilizados para evitar o crescimento de alguns microrganismos em alimentos, mas a crescente preocupação dos consumidores, a respeito dos potenciais riscos para a saúde que algumas destas substâncias podem ocasionar, incentivou a investigação da aplicação dos AMPs como biopreservantes. Pois muitos AMPs são isentos de cheiro e cor, não causam efeitos tóxicos ou outro adverso ao serem ingeridas (22), apresentam alta estabilidade térmica, alta resistência a variações de $\mathrm{pH}$ e à ação de algumas enzimas, e podem, ainda, ser facilmente hidrolisados no trato digestivo (23). Deste modo, AMPs foram considerados como substâncias inócuas pela OMS, podendo ser incorporadas em alimentos para humanos (24).

\subsubsection{Mecanismo de ação dos AMPs}

Alguns mecanismos de ação já foram descritos com o intuito de explicar a ruptura das membranas celulares que os peptídeos antimicrobianos catiônicos causam (25). Estes mecanismos são diferentes entre si, mas todos parecem depender do balanço entre as propriedades do peptídeo em questão e da composição da membrana plasmática do patógeno a ser atacado.

Os mecanismos mais conhecidos descrevem que o peptídeo adota uma estrutura tridimensionall ( $\alpha$-hélice, folha- $\beta$, loops $\beta$-estruturados, ou estruturas mistas) após interagir com a membrana bacteriana e se integrar à superfície externa dela. A partir desta etapa, podem ocorrer a formação de discretos poros ou canais na membrana celular do microrganismo que conduzirão à depolarização da bactéria, ou então à desintegração da membrana promovida pela solubilização dos componentes da membrana em agregados 
micelares, ou ainda à translocação do peptídeo através da membrana para alcançar um alvo intracelular, no qual o AMP se liga a algum receptor de membrana para ser internalizado em seguida.

Deste modo, o mecanismo de ação de um AMP pode variar de acordo com a célula que interage, e seu alvo pode ser tanto a membrana celular quanto alguma das organelas intracelulares. Além disso, estes mecanismos também não precisam ser mutuamente exclusivos. Um processo pode representar o passo inicial, ou o intermediário de outro.

Apesar das concentrações relativamente elevadas que são necessárias para a atividade dos AMPs (geralmente por volta de $\mu \mathrm{M}$ ), seu mecanismo de ação os torna interessantes pontos de partida para o desenvolvimento de novos agentes antimicrobianos. Como o modo de ação desses peptídeos depende da sua interação com a bicamada fosfolipídica da membrana celular via interações carga-carga e interações hidrofóbicas, a aquisição de resistência é restringida, visto que seria demasiadamente custoso, ou então, exigiria muitos eventos mutacionais para um microorganismo alterar a composição ou a organização dos seus lípidios a fim de enfraquecer essas interações.

\subsubsection{Bacteriocinas}

Os AMPs produzidos e secretados por bactérias, capazes de matar ou inibir o crescimento de cepas taxonomicamente próximas a que os produziu são definidos como bacteriocinas (26). No entanto, alguns estudos demonstram que essa definição necessita ser mais abrangente, pois bacteriocinas também impedem o desenvolvimento de bactérias que não tem relação taxonômica com a cepa produtora (27).

A classificação das bacteriocinas é frequentemente revisada para refletir as similaridades e diferenças observadas nos novos representantes descobertos. Baseado nas características estruturais, nas propriedades físico-químicas e moleculares, elas são divididas em três classes (24). A Classe I, chamada de lantibióticos, contém moléculas pequenas (menores que $5 \mathrm{kDa}$ ), catiônicas, hidrofóbicas, termicamente estáveis e produtos de modificações pós-traducionais. Além disso, são caracterizados pela presença de uma alta proporção de aminoácidos nãousuais (28).

Bacteriocinas da Classe II são moléculas variáveis em tamanho (geralmente entre 5 e 10 $\mathrm{kDa}$, também catiônicas, hidrofóbicas, termicamente estáveis, mas não sofrem 
processamentos pós-traducionais, assemelhando-se aos AMPs produzidos por células eucariontes, além de possuírem um amplo espectro de ação. Algumas possuem pelo menos duas cisteínas que formam ponte dissulfeto (29). Dentro desta classe, três subgrupos podem ser distinguidos: a subclasse IIa ou das pediocinas, que apresentam uma forte ação antilisterial, um segmento muito conservado na região N-terminal (YGNGVXaaC), e duas Cys formando uma ponte dissulfeto na região N-terminal do peptídeo; subclasse IIb, bacteriocinas que requerem duas cadeias polipeptídicas para a completa atividade, sendo a seqüência de aminoácidos diferente nas duas cadeias; e a subclasse IIc, moléculas que não pertencem aos primeiros dois grupos. A classe III das bacteriocinas é representado por proteínas grandes (maiores que $30 \mathrm{kDa}$ ), hidrofílicas e termicamente instáveis.

As classes I e II das bacteriocinas são as mais bem estudadas, consequentemente, são as mais prováveis candidatas a serem usados na aplicação em alimentos. Quanto ao mecanismo de ação dessas duas classes de bacteriocinas, sabe-se que tais moléculas perturbam a integridade da membrana celular, o que conduz a um rápido efluxo de íons e soluto citoplasmáticos, como conseqüência ocorre uma parada instantânea de todos os processos biosintéticos (28). Muitos destes peptídeos, carregados positivamente, formam hélices-alfa anfipáticas na presença de vesículas lipídicas, sugerindo que a interação direta lipídio/peptídeo é mais importante para sua atividade que a associação específica com um receptor. Esta classe de peptídeos exerce sua atividade antibiótica através da permeabilização de membranas das células sensíveis. No entanto, os mecanismos de permeabilização não são totalmente conhecidos e vários modelos têm sido propostos para explicar as interações entre polipeptídeos e bicamadas lipídicas (30-32).

Os estudos da atividade biológica, mecanismos de ação e aplicação das bacteriocinas como biopreservantes é limitado pelo elevado custo dos procedimentos para a obtenção e purificação dessas moléculas em suas fontes naturais, além do baixo rendimento no final do processo. Desse modo, a obtenção destes peptídeos através da síntese química é uma das maneiras de vencer esta limitação, além de permitir o avanço nos estudos sobre suas relações de estrutura/função. 


\subsubsection{Peptídeos antimicrobianos de bactérias acido-lácticas}

Bactérias ácido-lácticas (LAB, lacti acid bacteria) são atualmente exploradas como um reservatório de AMPs com potenciais aplicações tecnológicas, sendo os organismos de escolha de vários processos de fermentação de alimentos, porque são seguras de serem consumidas $(26,28)$. O mercado consumidor demonstra marcada preferência pelos alimentos livres de aditivos químicos, que são largamente usados como preservantes pela indústria, assim os estudos sobre o emprego tecnológico das LAB tem sido intensificado.

Além dos produtos finais derivados da fermentação de ácidos orgânicos (lático, acético), dióxido de carbono, peróxido de hidrogênio, diacetil, e outros $(33,34)$ produzidos por estas bactérias, que per si já agem como preservantes, foram descritos peptídeos com ações antimicrobianas, sobre os quais a indústria alimentícia demonstra um grande interesse devido suas potenciais aplicações $(33,35)$.

Nesse sentido, foram descritas centenas de bacteriocinas, produzidas por cepas selecionadas de diferentes origens (alimentos fermentados, frutas, intestino de animais, etc. (36,37). Além de serem isolados de diferentes fontes, estes peptídeos apresentam grande variedade de tamanho, estruturas primária e secundária, $(15,16)$. Entretanto eles apresentam características comuns: a maioria é catiônica, freqüentemente anfifílica e atuam alterando a permeabilidade da membrana celular $(38,39)$.

Os AMPS produzidos pelas LABs são empregados para fermentação e preservação de uma grande variedade de produtos lácteos, como também na preservação de produtos derivados de carnes e de vegetais, prevenindo assim o desenvolvimento de microorganismos contaminantes não desejados, alguns exemplo estão descritos na Tabela 2 (24).

Muitas bacteriocinas produzidas pelas LAB têm sido purificadas e caracterizadas (40), a maioria delas pertence à classe II. Um dos grupos da LABs estudadas são as bacteriocinas produzidas por Lactobacillus plantarum. 
Tabela 2 - Uso de AMP em produtos alimentícios

\begin{tabular}{lll}
\hline Alimento & Origem (cepa) & Atividade contra \\
\hline Broto de feijão & Lac. lactis subsp lactis (NisZ) & L. monocytogenes Scott A \\
Leite de cabra & Leu. mesenteroides Y105 & L. monocytogenes \\
Linguica fermentada & Lac. plantarum SA6 & Lactobacillus sp \\
Linguica fermentada seca & Lac. Lactis (NisA) & L. monocytogenes \\
Linguiça seca & Lac. plantarum UG1 & L. monocytogenes, Bacillus \\
& & cereus, C. perfringens, C. \\
Presunto & C. piscicola JG126 & sporogenes \\
Queijo francês macio & Carnobacterium piscicola CP5 & Carnobacterium, Listeria e \\
& & Enterococcus sp \\
Queijo francês tradicional & Ent. faecalis EFS2 & L. inocua \\
Rabanete & Lac. lactis supsp. cremoris R & Clostridium, Listeria \\
Trigo & & Staphylococcus e \\
Vegetais & & Leuconostoc sp \\
Salada Waldorf & Eac. plantarum BFE905 & L. monocytogenes \\
& Enterococcus mundtii & L.monocytogenes e C. \\
& & botulinum \\
\hline
\end{tabular}

\subsubsection{Plantaricinas}

Lactobacillus plantarum é uma das cepas mais distribuídas na natureza com elevada importância em muitos processos de fermentação de alimentos e como um componente natural da microflora intestinal, além de ser frequentemente usada na cultura de embutidos (41), carnes, vegetais, silagem e certos produtos derivados do leite. Desta cepa, pelo menos 15 bacteriocinas já foram descritas, de acordo com a Tabela 3 (42). No entanto, a maioria delas foram somente identificadas, apenas poucas foram purificadas, seqüenciadas e parcialmente caracterizadas. 
Dentre as bacteriocinas da Tabela 3 , entre as mais conhecidas e estudadas está a Plantaricina A (PlnA) que é um peptídeo catiônico com atividade antimicrobiana permeabilizante de membranas que é exportado para fora da célula por uma maquinaria de secreção de bacteriocinas que reconhece especificamente uma seqüência líder do peptídeo precussor de PlnA (43). Com exceção deste peptídeo as informações estruturais sobre as outras bacteriocinas de L. plantarum ainda continua limitada.

Em geral, as Plantaricinas são ativas contra espécies bacterianas relacionadas estreitamente à cepa produtora, do ponto de vista taxonômico, e apresentam uma ampla variedade estrutural, o que não permite agrupá-las em uma única classe de bacteriocinas.

Tabela 3 - Bactericinas produzidas por $L$. plantarum

\begin{tabular}{ll}
\hline Plantaricina & Cepa \\
\hline Plantaricina 149 & L. plantarum NRIC 149 \\
Plantaricina 35d & L. plantarum 35d \\
Plantaricina 406 & L. plantarum MI406 \\
Plantaricina 423 & L. plantarum 423 \\
Plantaricina A & L. plantarum C-11 \\
Plantaricina B & L. plantarum NDCO 1193 \\
Plantaricina BN & L. plantarum BN \\
Plantaricina C & L. plantarum LL441 \\
Plantaricina C19 & L. plantarum C19 \\
Plantaricina F & L. plantarum BF001 \\
Plantaricina LC74 & L. plantarum LC74 \\
Plantaricina S & L. plantarum LPCO-10 \\
Plantaricina SA6 & L. plantarum SA6 \\
Plantaricina SIK 83 & L. plantarum SIK 83 \\
Plantaricina T & L. plantarum LPCO-10 \\
\hline
\end{tabular}

Há alguns anos, o grupo de Biofísica Molecular Sérgio Mascarenhas do Instituto de Física de São Carlos da USP, em colaboração com o Departamento de Química Orgânica da Universidad Nacinal del Litoral, Santa Fé - Argentina, iniciaram os estudos para a construção de um peptídeo antimicrobiano análogo a Plantaricina 149 e sua caracterização 
estrutural/funcional (44). Tal peptídeo mostrou atividades interessantes contra bactéricas patogenicas ao homem, tais como Staphylococcus aureus e Listeria monocytogenes.

\subsection{Plantaricina 149 (Pln149)}

Pln149 um peptídeo antimicrobiano produzido pela cepa da bactéria láctica Lactobacillus plantarum NRIC 149, inicialmente isolado em abacaxi. O AMP é composto por uma cadeia polipeptídica linear de 22 resíduos de aminoácidos (YSLQMGATAIKQVKKLFKKKGG), termoestável, de natureza catiônica, sensível à papaína, tripsina e pepsina e sua atividade é dependente do $\mathrm{pH}$ (máxima a $\mathrm{pH}$ 5,0). Seu espectro de ação inclui: Lactobacillus plantarum, L. delbrueckii, L. delbrueckii subsp. bulgaricus, L.helveticus, L.casei, Leuconostoc mesenteroides, Pediococcus acidilactici, P. cerevisiae, Enterococcus hirae e Lactococcus (41).

As propriedades demonstradas para esta Plantaricina sintética a tornam atrativa para ser utilizada na indústria alimentícia como preservante alimentar. Além disso, a atividade detectada tanto a pH 5.0 como em pH 7.4 também desperta o interesse em investigar a sua possível utilização a nível terapêutico. Recentes trabalhos, demonstraram que Pln149a sintética, inibe uma cepa de Staphylococcus aureus e quatro de Listeria monocytogenes com efeito bactericida. Provavelmente, o mecanismo de ação de Pln149 se assemelhe ao da Plantaricina A quanto à capacidade de formar uma hélice anfipática ao interagir com componentes da membrana, induzindo alterações conformacionais nas mesmas. Por outro lado, apesar da notória identidade seqüencial entre essas duas bacteriocinas, o espectro antimicrobiano de Pln149 sintética mostrou-se diferente da Plantaricina A e também da própria bacteriocina nativa, as quais não mostram atividade sobre as bactérias acima citadas, ambas patógenas encontradas em alimentos (44).

O espectro de dicroísmo circular deste peptídeo sintético, em solução aquosa, tem estrutura não ordenada (86\%), porém sua interação com micelas reversas de AOT (AerosolOT [bis (2-etil-hexil) sulfosuccinato de sódio]), que mimetizaria um ambiente de membrana, leva a mudanças conformacionais, mostrando um espectro típico de proteínas contendo $\alpha$ hélices. A desconvolução mostrou valores de hélice ao redor de $74 \%$ e $26 \%$ de estruturas não ordenadas. 
Cabe ainda a realização de estudos complementares e mais detalhados sobre o mecanismo de ação de Pln149 sintética frente a sistemas modelos de membrana mais próximos às membranas celulares de bactérias, e também a investigação de sua ação antimicrobiana frente a diferentes tipos de microorganismos.

\subsection{Objetivos}

Com o objetivo geral de contribuir para a elucidação do mecanismo de ação de Plantaricina 149 e adquirir conhecimento sobre o binômio estrutura/função do peptídeo, o seguinte trabalho pretende caracterizar a interação deste peptídeo com diferentes sistemas modelos de membrana por meio de estudos conformacionais e ensaios de atividade antimicrobiana do peptídeo e peptídeos derivados sobre diferentes cepas de bactérias e leveduras.

De acordo com o objetivo geral do trabalho, as seguintes etapas foram desenvolvidas:

- Síntese de Pln149 sintética e outros peptídeos análogos em fase sólida.

- Purificação dos peptídeos por técnicas cromatográficas, utilizando colunas de cromatografias de fase reversa;

- Determinação das massas moleculares, por Espectrometria de Massas, como critério de homogeneidade e checagem da seqüência de síntese, pela degradação automatizada de Edmann;

- Estudo das propriedades de Pln149a em solução aquosa, em função do pH, adição de metanol e concentração iônica;

- Estudo da interação dos peptídeos análogos da Plantaricina 149, monitorando a estrutura secundária dos peptídeos por dicroísmo circular na presença e na ausência de vesículas unilamelares;

- Seleção dos fosfolipídios (DPPC, DPPG, DPPS, DPPE, e outros) cuja interação com os peptídeos seja mais significativa; analisando a interação em LUVs (Large Unilamellar Vesicles);

- Investigação do micro ambiente dos fluoróforos presentes nos peptídeos por espectroscopia de emissão de fluorescência; 
- Investigar a alteração da pressão do empacotamento de monocamadas dos fosfolipídios pela ação de $P \ln 149$, e determinar possíveis concentrações criticas de desestruturação dessas monocamadas;

- Utilização da técnica de ressonância plasmônica de superfície para monitorar a interação destes peptídeos com os fosfolipídios;

- Ensaios de ITC para determinar os parâmetros termodinâmicos da interação dos peptídeos com LUVs;

- Investigar a atividade hemolítica dos peptídeos sintetizados

- Investigar o espectro de ação de Pln149a frente a diferentes bactérias patogênicas, e determinar concentrações inibitórias mínimas frente a essas cepas;

- Avaliar a ação de Pln149a frente a leveduras, tais como Saccharomyces cerevisiae;

- Investigar a ação de Pln149 frente a células tumorais de mamíferos. 
MATERIAIS

Nenon 



\section{MATERIAIS E MÉTODOS}

\section{1 MATERIAIS}

\section{1.1 Materiais e Equipamentos utilizados}

- $\quad$ pHmetro;

- $\quad$ Termômetros;

- $\quad$ Placas de Petri;

- $\quad$ Microplacas de 96 poços;

- $\quad$ Tubos de polietileno e de vidro de fundo cônico (5 e $15 \mathrm{~mL}$, âmbar e transparentes);

- $\quad$ Sangue humano (obtido de doadores do grupo de Biofísica do IFSC);

- $\quad$ Bomba de vácuo (Fisher Scientific);

- $\quad$ Geladeira $\left(4^{\circ} \mathrm{C}\right)$ e freezer $\left(-20^{\circ} \mathrm{C}\right)$ convencionais;

- $\quad$ Banho-maria (FANEM, Brasil);

- Vórtex;

- Balanças analíticas e convencionais;

- $\quad$ Mini extrusor (Avanti Polar Lipids);

- Thermobarrel Extruder, extrusor automatizado com fluxo sob pressão de nitrogênio, (Lipex Biomembranes Inc.);

- $\quad$ Sonicador de ponta Sonic Dismembrator model 500 ((Fisher Scientific)

- Membranas de policarbonato/poliéster com poros de $100 \mathrm{~nm}$ (Whatman);

- $\quad$ Osmômetro digital (Fiske One-Ten);

- $\quad$ Sistema centrífugo/liofilizador Savant (Speedvac);

- $\quad$ Sistema para cromatografia de alta pressão HPLC (Bio-rad, Califórnia - EUA);

- Sistema para cromatografia de alta e baixa pressão ÄKTA purifier system (GE Healthcare);

- $\quad$ Cubetas retangulares de quartzo, caminho óptico $1 \mathrm{~mm}$ para $\mathrm{CD}$;

- Cubetas retangulares de quartzo, caminho óptico $1 \mathrm{~cm}$ e $3 \mathrm{~cm}$ para fluorímetro;

- $\quad$ Centrífuga de bancada Excelsa Baby II modelo 206-R (FANEM, Brasil); 
- $\quad$ Centrífuga refrigerada comum (modelo 5B e RC5C plus, Sorval);

- $\quad$ Leitor de microplacas Model 2100 (Awareness Technology Inc.);

- $\quad$ Leitor de microplacas TP-reader (Thermoplate)

- $\quad$ Espectrofotômetro mod U-2001 (Hitachi);

- $\quad$ Espectrofotômetro mod U-2801 (Hitachi);

- $\quad$ VP-ITC MicroCalorimeter (Microcal, MA-USA);

- $\quad$ Calorímetro Seratam Micro DSCII Set Soft 2000;

- $\quad$ Espectrofluorimetero Perkin-Elmer (Beaconsfield Bucks, UK) LS 50;

- $\quad$ Espectrofluorímetro ISS K2 (ISS Fluorescence, Analytical and Biomedical Instruments);

- Espectropolarímetro Jasco modelo J-815 CD Spectrometer (Tokio, Japão) acoplado com banho TC-100 (Peltier) para experimentos de desnaturação térmica;

- $\quad$ BIAcore X (BIACORE AB, Upsala, Suécia) e sensorchips HPA e L1;

- $\quad$ Seqüenciador automatizado de proteínas modelo PPSQ-23A Shimadzu (Kyoto, Japão);

- Espectrômetro de massa modelo Quattro 2 Eletrospray Triple Quadrupole MS (Micromass, Manchester, UK);

- Tensiômetro automático modelo OCA-20 (Dataphysics Instruments GmvH, Alemanha) contendo acessório de oscilação ODG-20;

- $\quad$ Microscópio Electrônico de Varredura Zeiss-DSM 960 (Oberkochen, Alemanha)

\section{1.2 Reagentes e resinas}

Os solventes e reagentes químicos utilizados foram de grau para HPLC ou P.A. São eles: Água MilliQ, Acetonitrila (Fisher Scientific ou Aldrich), ácido acético, acetato de sódio, borato de sódio, fosfato de sódio, $\mathrm{NaCl}, \mathrm{NaOH}$, metanol, clorofórmio, glutaraldeído, ácido perclórico, ácido sulfúrico, heptamolibdato de amônio, ácido ascórbico, citrato de sódio, etanol, éter etílico, $\mathrm{HCl}$, TFA (ácido trifluoroacético, J.T. Baker), Tris-HCl, $\mathrm{KH}_{2} \mathrm{PO}_{4}, \mathrm{HEPES}$ (ácido hidroxietil-piperazinaetanosulfônico), NATA (N-acetil-triptofanamida), DMF (dimetilformamida, Dorwil) após passagem por processo de destilação fracionada, DMF (grau de síntese de peptídeos, Applied Biosystems), piperidina, ninhidrina, PyBOP (hexafluorofosfato de benzotriazoil-oxitripirrolidinofosfonio), DCM (diclorometano), TIS (triisopropil-silano), HMDS (hexametildisilazano), Triton X-100, OGP (N-octil-glicopiranosídeo), ANTS (ácido 
aminonaftaleno trisulfonico), DPX (p-xileno-bis-brometo de piridinio), EDT (etanoditiol), DIEA (diisopropil-etilamina), os ativadores HOBt (hidroxibenzotriazol), TBTU (tetrametil-obenzotriazoil tetrafluoroborato-uronio) e HATU (hexafluorofosfato de azabenzotriazoil tetrametil-uronio metanaminio), os carboidratos D-Manose, D-Galactose, D-Glicose, DMaltose, D-Sacarose, $\alpha$-metil-D-Manosídeo, N-acetil-D-Galactosamina, Galactomanana e Carragena.

Durante a síntese de peptídeos utilizou-se a resina Rink Amide (resina 4-(2',4'dimetoxifenil-Fmoc-aminometil fenoxi) (NovaBiochem), e a Tentagel R Ram (Rink Amide),

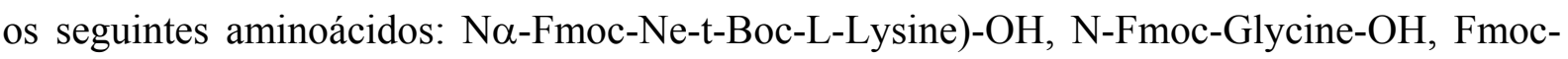
L-Phenylalanine-OH, N-Fmoc-L-Leucine-OH, N-Fmoc-L-Valine-OH, No-Fmoc-N $\gamma$-trityl-LGlutamine-OH， N-Fmoc-O-t-butyl-L-Serine-OH， N-Fmoc-O-t-butyl-L-Tyrosine-OH， NFmoc-L-Isoleucine-OH, Fmoc-L-Alanine-OH, N-Fmoc-O-t-butyl-L-Threonine-OH, N-FmocL-Methionine(O)-OH, Na-Fmoc-Tryptophan(Boc)-OH (Calbiochem Novabiochem Corp, California,USA).

As resinas cromatográficas utilizadas foram: Sephadex G-75 (Pharmacia LKB Biotechnology, Uppsala, Suécia), coluna de fase reversa $C_{18}(250 \times 4.6 \mathrm{~mm}$, partícula $6 \mu \mathrm{m}$ YMC Inc, Waters, Alemanha) e coluna Vydac $\mathrm{C}_{18}(250$ x $10 \mathrm{~mm}, 10 \mu)$.

Os demais reagentes estão descritos ao longo da seção métodos.

\section{2 MÉTODOS}

\section{2.1 Síntese de peptídeos}

A síntese química direta de peptídeos é uma técnica que permitiu o avanço nos estudos de caracterização estrutural/funcional, metabolismo e degradação, bem como nas diferentes atividades biológicas e papéis que os peptídeos podem desempenhar. Tal abordagem foi mais facilmente difundida e explorada com o advento da síntese de peptídeos em fase sólida (SPPS, Solid-phase peptide synthesis), que foi introduzida na comunidade científica pela primeira vez por Bruce Merrifield em 1963 (45) e se tornou o método mais corriqueiro, mais conhecido e mais simples para a construção de peptídeos sintéticos. Pois, além de ser uma técnica cujo 
procedimento fornece bons rendimento do produto final, ela permite a síntese de peptídeos naturais cuja expressão em bactérias é difícil, e ainda, a incorporação de aminoácidos não naturais nas cadeias polipeptídicas, ou mesmo a inserção de modificações nas cadeias polipeptídicas sintetizadas, nas suas cadeias laterais e/ou nos seus grupos amino-terminais (46).

As duas estratégias de SPPS mais utilizadas são conhecidas como química de Boc (tertbutil-oxi-carbonil) e química de Fmoc (9-fluorenil-metil-oxi-carbonil). Elas se distinguem, principalmente, pelo tipo do grupo protetor que é adicionado a porção amino-terminal do aminoácido a ser utilizado na construção do peptídeo, que pode ser do tipo Boc ou então do tipo Fmoc. Este grupo é denominado proteção temporária e suas estruturas estão mostradas na Figura 1.

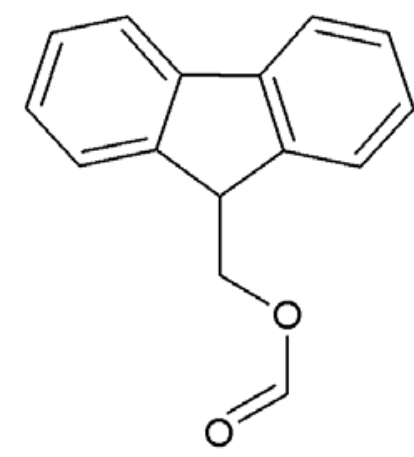

Fmoc

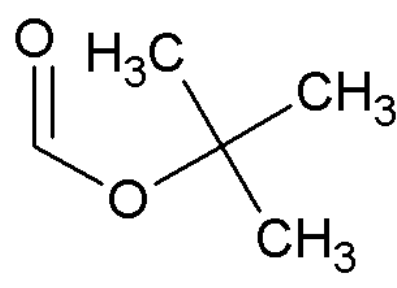

Boc

Figura 1 - Protetores temporários da química de Fmoc e Boc. Em cada uma das duas estratégias, estes grupos estão ligados ao N-terminal de cada um dos aminoácidos a serem usados na construção do peptídeo desejado, e serão retirados antes do acoplamento do resíduo de aminoácido seguinte.

Além dos grupos protetores Fmoc e Boc, alguns aminoácidos com cadeias laterais mais extensas apresentam um segundo grupo protetor, chamado de proteção permanente, a fim de minimizar as possíveis polimerizações ou reações não desejadas destes grupos durante as etapas de síntese. Estes grupos protetores dependem do grupo funcional do aminoácido e da estratégia de síntese a ser utilizada. Eles só serão retirados após a incorporação do último resíduo de aminoácido ao peptídeo construído, geralmente no momento da clivagem do peptídeo da resina polimérica.

As resinas mais utilizadas na SPPS são as de poliestireno ou de poliamida. Elas são pequenas partículas sólidas insolúveis e porosas que receberam tratamento com unidades funcionais denominados conectores, sobre os quais a cadeia polipeptídica pode ser construída. 
O peptídeo é covalentemente acoplado a resina até a sua clivagem feita por reagentes tais como o TFA.

De modo geral, o método da SPPS se baseia na união do aminoácido da extremidade carboxi-terminal (C-terminal) do peptídeo a ser construído ao conector que está acoplado ao suporte polimérico insolúvel (resina) contido dentro de uma coluna. Este conector pode variar de acordo com o tipo de polipeptídio que se deseja obter (peptídeos-amida, carboxi-peptídeos, tipo aldeído).

O princípio da técnica de SPPS para a elongação da cadeia polipeptídica se dá mediante a adição de aminoácido por aminoácido, através da repetição de ciclos de acoplamento de aminoácidos que apresentem grupos protetores temporários e permanentes convenientes (47). A eliminação da proteção temporária ocorre antes da união do aminoácido seguinte, conforme esquematizado na Figura 2. A eliminação do grupo protetor Boc, por exemplo, se dá em meio ácido, enquanto a do grupo Fmoc ocorre em meio básico.

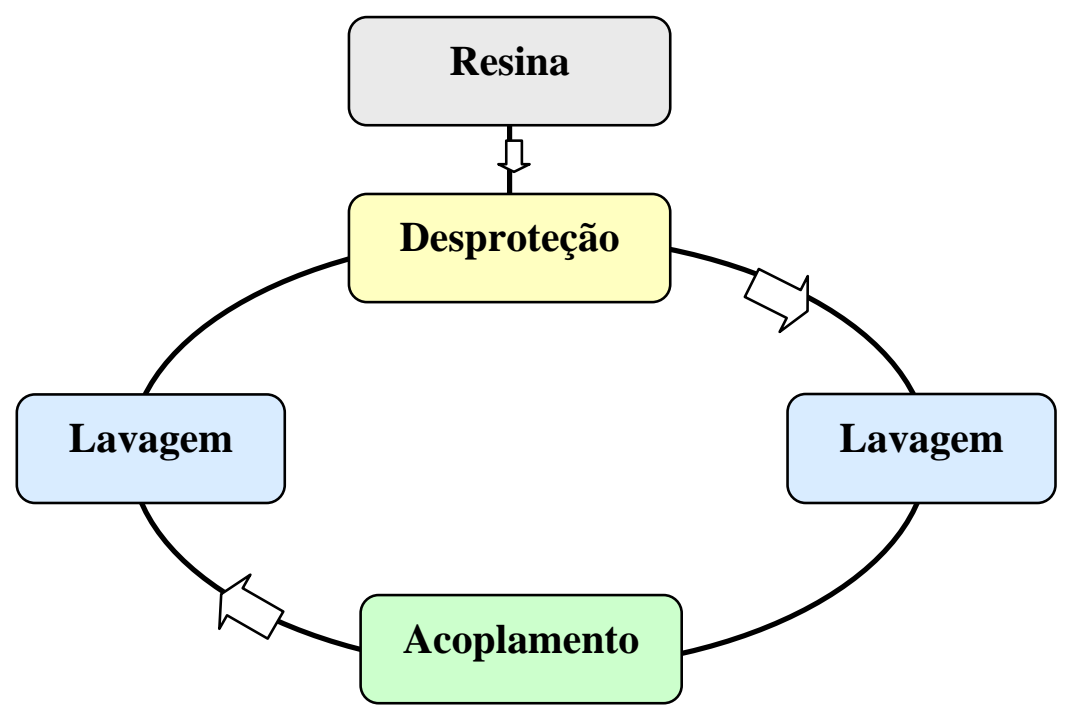

Figura 2 - Esquema dos ciclos de reação de síntese de peptídeos. Após solvatação da resina, retirada dos protetores temporários e lavagens, a síntese de peptídeos consiste numa série de etapas de acoplamento e desproteção dos resíduos de aminoácidos que são repetidas até atingir o fim da seqüência do peptídeo de interesse.

Uma vez que o grupo amina da extremidade N-terminal do peptídeo a ser construído se encontre livre, pode-se, então, promover a sua ligação ao aminoácido seguinte, a fim de formar uma ligação peptídica entre os dois resíduos. Este processo de acoplamento requer a ativação do grupo carboxílico do aminoácido a ser adicionado, de modo que este seja capaz de reagir com a extremidade amino-terminal da cadeia polipeptídica crescente, conforme 
mostrado na Figura 3. Os processos de acoplamento e desproteção são repetidos quantas vezes forem necessárias, a fim de que se complete a seqüência de aminoácidos desejada.

Durante a síntese de peptídeos em fase sólida, para que se obtenha um bom rendimento do peptídeo final, uma etapa fundamentalmente importante é assegurar que cada etapa de acoplamento/desproteção seja realizada com uma alta eficiência.

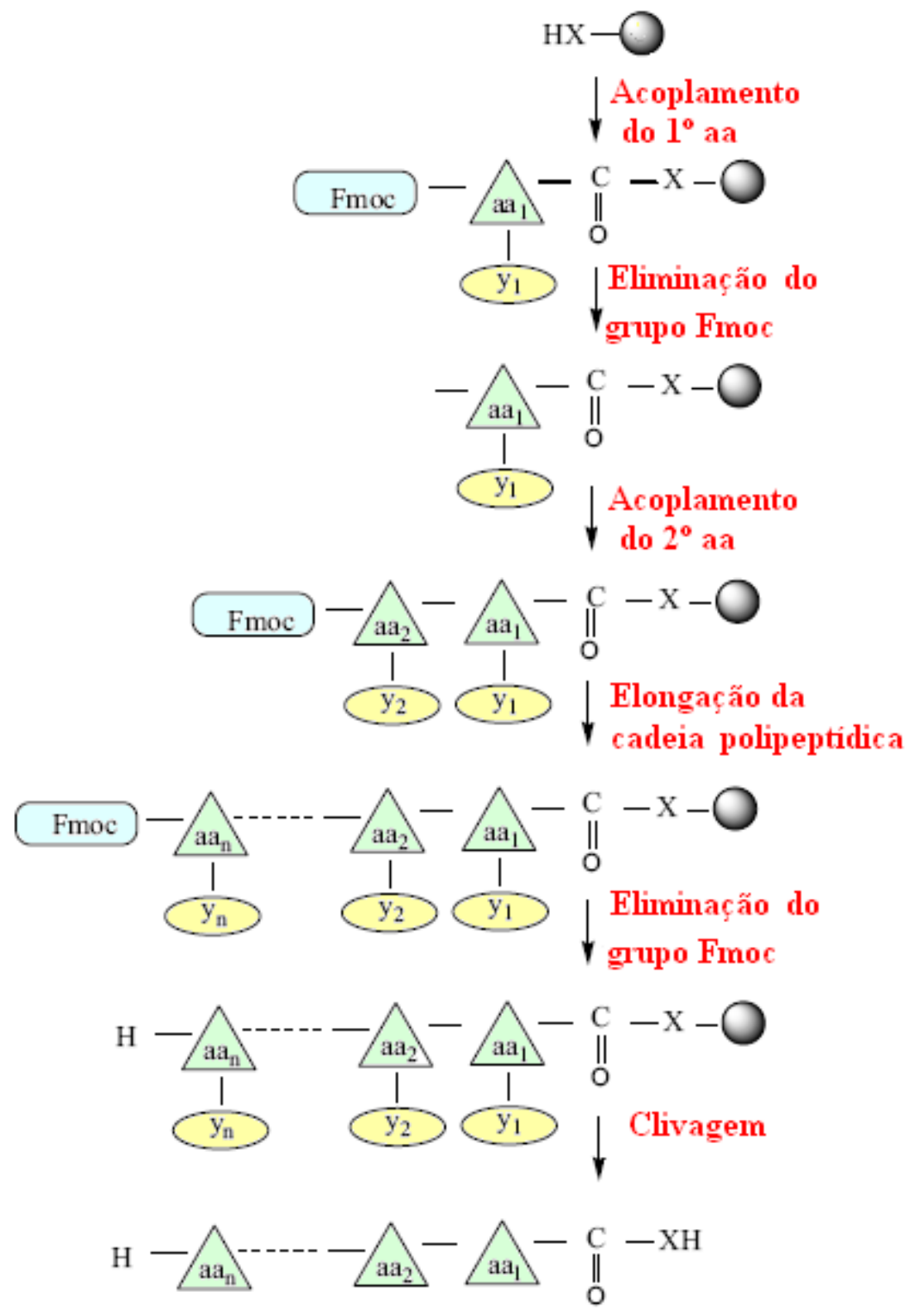

Figura 3 - Esquema de SPPS com a estratégia de Fmoc. Após solvatação e desproteção da resina (esfera cinza), a síntese de peptídeos consiste numa série de etapas de desproteção do grupo Fmoc (azul) e acoplamento dos resíduos de aminoácidos (triângulos em verde). A última etapa da síntese é a clivagem da cadeia polipeptídica da resina polimérica, que acontece simultaneamente à eliminação dos protetores permanentes adicionados às cadeias laterais dos resíduos de aminoácidos (amarelo). 
Deste modo, de maneira oposta à síntese de proteína nos ribossomos, a técnica de SPPS se dá na direção do C para o N-terminal do peptídeo, ou seja, o resíduo que se deseja obter na extremidade C-terminal do peptídeo se acopla a matriz da resina, e o último aminoácido a ser acoplado será o resíduo do N-Terminal. Uma vez sintetizada a cadeia polipeptídica, promovese a sua separação do suporte polimérico e a eliminação dos grupos protetores das cadeias laterais dos aminoácidos, geralmente em uma única etapa.

Como a síntese de peptídeos envolve várias etapas repetitivas, o uso de um suporte sólido para o crescimento da cadeia polipeptídica apresenta grandes vantagens em respeito a síntese de peptídeos em solução. Com este sistema pode-se utilizar um excesso de reagentes que fazem com que as reações de acoplamento atinjam a máxima eficiência, atingindo bons rendimentos. $\mathrm{O}$ fato de se trabalhar com o peptídeo no suporte sólido, facilita a eliminação do excesso de reagentes e dos demais produtos de síntese por um simples processo de filtração, seguido por lavagens, fáceis de serem automatizadas. O peptídeo, uma vez imobilizado sobre a fase sólida, é retido durante o processo de filtração, no qual os reagentes da fase líquida e os outros produtos da síntese são descartados. Além disso, todas as etapas de síntese podem ocorrer num mesmo recipiente, sem nenhuma necessidade de transferência de material.

\section{2.1.1 Síntese do análogo a Plantaricina149}

A construção do peptídeo Plantaricina 149 sintético (Pln149a) foi realizada no laboratório de Síntese de Péptidos Bioactivos da Universidad Nacional del Litoral, Santa Fé, Argentina em colaboração com a Profa. Dra. Georgina Tonarelli e seu grupo de pesquisa, durante a realização de um treinamento em síntese de peptídeos de dois meses em seu laboratório.

A síntese foi realizada de modo a fornecer peptídeos tipo amida, ou seja com um conector que fornecesse o peptídeo final com um grupo carboxamida no C-terminal. As etapas realizadas durante a síntese de Pln149a (YSLQMGATAIKQVKKLFKKKGG - amida) estão descritas abaixo:

a) Acoplamento - Partiu-se de uma quantidade de $151.2 \mathrm{mg}$ de resina Rink Amide, com uma capacidade de síntese de $0.54 \mathrm{mmol} / \mathrm{g}$. Inicialmente, a resina foi solvatada em DMF por 20 
min (3 ciclos), e em seguida desprotegida com piperidina 20\% em DMF (2 ciclos de 20 min). O monitoramento da eficiência das reações de desproteção e acoplamento foi realizado por uma reação colorimétrica de ninhidrina, conforme descrito no método de Kaiser (48). Uma vez confirmada a eficiência da desproteção da resina, o acoplamento do primeiro aminoácido foi promovido solubilizando o dobro da quantidade de aminoácido que a resina consegue acoplar (proporção: 2 moles de aa: 1 mol resina) em DMF. Além dos aminoácidos utilizaramse os ativadores de acoplamento TBTU, HOBT, e DIEA, todos seguindo a mesma proporção 2:1. A mistura foi colocada em agitação com a resina numa seringa por cerca de 50 minutos.

b) Desproteção - Uma vez verificado que o acoplamento foi realizado com sucesso, a resina foi lavada 6 vezes com DMF (6 X de $3 \mathrm{~mL}$ ). A etapa posterior foi a eliminação dos grupos Fmoc do aminoácido acoplado com piperidina a 20\% em DMF, seguida de novas lavagens para a preparação para o próximo acoplamento. Esta etapa foi repetida de 2-3 vezes, até a obtenção de um ensaio de ninhidrina positivo para a desproteção.

c) Clivagem - Após o acoplamento do ultimo resíduo de aminoácido e/ou das modificações adicionadas no N-terminal dos peptídeos, a resina foi lavada com DMF, e posteriormente os peptídeos foram clivados dela pela incubação com uma solução composta de $94 \%$ de TFA, $2.5 \%$ de TIS, $1 \%$ EDT e $2.5 \%$ de água milliQ.

Após 3 horas de clivagem da resina, os peptídeos foram filtrados da seringa, precipitados em éter etílico gelado, e, posteriormente centrifugados a $3000 \mathrm{rpm}$ por $10 \mathrm{~min}$. O sobrenadante foi descartado e o precipitado foi lavado algumas vezes com éter etílico, promovendo a solubilização num vórtex, seguida de nova centrifugação. Este processo foi repetido por 10 vezes, e por fim, o peptídeo precipitado foi dissolvido em água e levado a um dessecador overnight para liofilização.

\section{2.1.2 Síntese do derivado com Serina}

Outros $151 \mathrm{mg}$ da resina Rink amide foram utilizados para a síntese de outro peptídeo análogo da Plantaricina149, denominado Pln149S. Este peptídeo contém a substituição do resíduo de Tyr na posição 1 de Pln149 para um resíduo de Ser. 
Pln149S SSLQMGATAIKQVKKLFKKKGG-amida

Deste modo, as mesmas etapas de a), b) e c) da seção 2.2.1.1 foram repetidas para que todos os aminoácidos fossem adicionados à cadeia polipeptídica, e se adquirisse o peptídeo livre do suporte polimérico.

\section{2.1.3 Síntese dos derivados com modificações no N-terminal}

Outro grupo de peptídeos derivados de Pln149 foi sintetizado com o mesmo protocolo e a mesma seqüência de aminoácidos como Pln149a, mas promovendo a redução do tamanho do peptídeo, iniciando com o resíduo de Gly da posição 6 e terminando com o Gly na posição 22. Para esta síntese, partiu-se de uma quantidade de $500.6 \mathrm{mg}$ da resina Rink Amide, e prosseguiram-se com as etapas a) e b) da seção 2.2.1.1 até o adquirir a sequencia polipeptídica de GATAIKQVKKLFKKKGG junto ao suporte polimérico.

Nesta etapa, a resina contendo a cadeia polipeptídica acoplada foi pesada e divida em quatro partes iguais, de modo a seguir com quatro sistemas independentes de síntese. Após o acoplamento do último aminoácido destes grupos e a divisão da peptidil-resina nestas 4 partes, algumas modificações foram inseridas no N-terminal de cada uma das frações, conforme descrito a seguir:

- Acetilação: nesta fração da peptidil-resina, após a realização de um ciclo de desproteção a adição de um grupo acetil ao N-terminal dos peptídeos foi promovida pela adição de $6 \mathrm{~mL}$ de anidrido acético $20 \%$ em DMF por 5 min de incubação, seguido pela adição de $100 \mu \mathrm{L}$ de DIEA e incubação por mais 30 min (ou até obter um ensaio de ninhidrina negativo);

- Acilação: a incorporação de um grupo acil (N-octil) ao N-terminal desta parte da resina (0.125 g) foi promovida pela solubilização do ácido octanóico (caprílico) em DMF, na proporção 1:1 com a capacidade de acoplamento da resina, seguida pela adição de DIPEA, HBOt e PyBOP, na mesma proporção, e incubação com a resina por 2 horas. Um ensaio colorimétrico com ninhidrina confirmou a incorporação do ácido ao N-terminal do peptídeo. 
- Conservação do grupo Fmoc: nesta parte da resina não houve a etapa de desproteção, gerando peptídeos contendo o grupo Fmoc na extremidade N-terminal;

- Remoção do grupo Fmoc: esta etapa não representou a inserção de um grupo funcional, mas na realidade, consistiu de uma desproteção com piperidina 20\% em DMF, gerando peptídeos com o N-terminal livre;

A etapa c) da seção 2.2.1.1 foi realizada com cada um destes sistemas de síntese, porém a mistura de clivagem foi como descrita a seguir: 95\% de TFA, $2.5 \%$ de TIS e $2.5 \%$ de água. A composição desta mistura foi selecionada em função dos grupos protetores das cadeias laterais dos aminoácidos utilizados em cada síntese.

Desta forma, promoveu-se a síntese dos seguintes peptídeos:

$$
\begin{array}{lr}
\text { Pln149(6-22) } & \text { GATAIKQVKKLFKKKGG - amida } \\
\text { Fmoc-Pln149(6-22) } & \text { Fmoc-GATAIKQVKKLFKKKGG - amida } \\
\text { Ac-Pln149(6-22) } & \text { Ac-GATAIKQVKKLFKKKGG - amida } \\
\text { Noctil-Pln149(6-22) N-octil-GATAIKQVKKLFKKKGG-amida }
\end{array}
$$

\section{2.1.4 Síntese dos derivados com Triptofano}

A intenção dessa nova síntese foi incorporar um resíduo de triptofano (W) ao peptídeo estudado para que se pudesse monitorar a sua vizinhança por ensaios de emissão de fluorescência intrínseca, e determinar as constantes de ligação aos modelos de membrana negativamente carregadas através de ensaios de titulação. Para isso, do peptídeo nativo Pln149 substituiu-se o resíduo 17, que se trata de uma fenilalanina (F) para um resíduo de W.

A síntese de peptídeos derivados de Pln149 contendo o resíduo de triptofano foi realizada em duas etapas. Na primeira delas, $501.2 \mathrm{mg}$ da resina Rink amide foram utilizados para sintetizar 4 novos peptídeos análogos a Pln149, utilizando a mesma estratégia descrita na 
seção 2.2.1.3, porém substituindo-se o resíduo de Phe por um resíduo de Trp. Desta forma foram sintetizados os peptídeos:

$$
\begin{array}{lr}
\text { Pln149W(6-22) } & \text { GATAIKQVKKLWKKKGG-amida } \\
\text { Fmoc-Pln149W(6-22) } & \text { Fmoc-GATAIKQVKKLWKKKGG-amida } \\
\text { Ac-Pln149W(6-22) } & \text { Ac-GATAIKQVKKLWKKKGG-amida } \\
\text { Noctil-Pln149W(6-22) } & \text { N-octil-GATAIKQVKKLWKKKGG-amida }
\end{array}
$$

\author{
GATAIKQVKKLWKKKGG - amida \\ Fmoc - GATAIKQVKKLWKKKGG - amida \\ Ac - GATAIKQVKKLWKKKGG - amida
}

Já na outra etapa, outros dois peptídeos análogos a Pln149 foram sintetizados, também em fase sólida de forma manual pela química de Fmoc, mas agora utilizando a resina Tentagel R Ram (Rink Amide). A síntese destes dois últimos peptídeos foi realizada no Departamento de Química de Péptidos y Proteínas, do Consejo Superior de Investigaciones Científicas (CSIC) do Instituto de Investigaciones Químicas y Ambientales em Barcelona, Espanha, em colaboração com a Dra. Isabel Haro, durante o período de realização de estágio no exterior, onde permaneci neste grupo por 6 meses. Os novos peptídeos análogos foram denominados:

\section{Pln149W YSLQMGATAIKQVKKLWKKKGG-amida \\ Pln149WS SSLQMGATAIKQVKKLWKKKGG-amida}

A estratégia de síntese está descrita a seguir: Promoveu-se a solvatação de $1.0 \mathrm{~g}$ da resina com uma capacidade de $0.2 \mathrm{mmol} / \mathrm{g}$ em DMF. As reações de desproteção do grupo Fmoc foram realizadas com $20 \%$ de Piperidina (2 ciclos de $10 \mathrm{~min}$ ), e as reações de acoplamento, com o ativador HATU e a amina terciária DIEA por $15 \mathrm{~min}$. O monitoramento da eficiência das reações de desproteção e acoplamento foram realizados pelo teste qualitativo de ninhidrina. Antes do acoplamento do último resíduo de aminoácido, a peptidil-resina foi divida em duas partes iguais. Em uma delas se realizou o acoplamento de um resíduo de Tirosina (Y), enquanto na outra parte, acoplou-se um resíduo de Serina (S). Uma vez completada a síntese da seqüência peptídica, e antes de proceder com a clivagem, se eliminou o grupo Fmoc do aminoácido N-terminal com piperidina, e em seguida a resina foi lavada com acido acético, éter etílico e diclorometano ( 5 ciclos cada) a fim de eliminar a DMF. A 
clivagem da resina e a desproteção das cadeias laterais do peptídeo foram promovidas pela incubação da peptidil-resina numa mistura de TFA (94\%), TIS (1\%), EDT (2.5\%) e água (2.5\%) por 4 horas, seguida por filtração sob vácuo moderado.

Após clivagem, o solvente foi evaporado na presença de $\mathrm{N}_{2}$ e a fração bruta do peptídeo foi precipitada em éter etílico gelado. Esta fração foi posteriormente centrifugada a $3000 \mathrm{rpm}$ por $5 \mathrm{~min}$, na qual se descartou o sobrenadante e promoveu-se a solubilização do precipitado em éter etílico por agitação em vórtex, seguindo uma nova centrifugação. Por fim, após 10 repetições destes passos (ou ate desaparecerem os odores de tiol da amostra) o peptídeo precipitado foi dissolvido em uma mistura (1:1) de água/acetonitrila, e em seguida, liofilizado overnight.

Tabela 4 - Nome e seqüência dos peptídeos sintetizados. Três grupos de peptídeos foram definidos de acordo com a similaridade na estrutura primaria. Entre os membros de cada grupo, as modificações estão localizadas apenas no N-terminal das moléculas. Deste modo, como a direção da síntese se dá do C para o N-terminal, a síntese de cada um desses grupos foi realizada simultaneamente (num mesmo sistema, exceto grupo I), e assim prosseguindo até o acoplamento do último resíduo de aminoácido comum a todos os membros do grupo (Ser2 para o Grupo I e Gly6 para os grupos II e III). A partir deste ponto a resina foi dividida em partes iguais e a síntese de cada peptídeo prosseguiu individualmente, adicionando o ultimo resíduo de aminoácido ou um grupo Acetil, Fmoc ou N-octil.

\begin{tabular}{llr}
\hline & Nome & Seqüência \\
\hline Grupo I & Pln149a & YSLQMGATAIKQVKKLFKKKGG - amida \\
& Pln149S & SSLQMGATAIKQVKKLFKKKGG - amida \\
& Pln149W & YSLQMGATAIKQVKKLWKKKGG - amida \\
& Pln149WS & SSLQMGATAIKQVKKLWKKKGG - amida \\
\hline Grupo II & Pln149(6-22) & GATAIKQVKKLFKKKGG - amida \\
& Fmoc-Pln149(6-22) & N-Fmoc-GATAIKQVKKLFKKKGG - amida \\
& Ac-Pln149(6-22) & Ac-GATAIKQVKKLFKKKGG - amida \\
& Noctil-Pln149(6-22) & N-octil-GATAIKQVKKLFKKKGG - amida \\
\hline Grupo III & Pln149W(6-22) & GATAIKQVKKLWKKKGG - amida \\
& Fmoc-Pln149W(6-22) & N-Fmoc-GATAIKQVKKLWKKKGG - amida \\
& Ac-Pln149W(6-22) & Ac-GATAIKQVKKLWKKKGG - amida \\
& Noctil-Pln149W(6-22) & N-octil-GATAIKQVKKLWKKKGG - amida \\
\hline
\end{tabular}




\section{2.2 Caracterização dos peptídeos}

Após a síntese de cada um dos peptídeos derivados de Pln149, foram checadas a incorporação de todos os resíduos de aminoácido, a seqüência correta da cadeia polipeptídica, e a incorporação dos grupos funcionais nos peptídeos modificados.

Esta avaliação da estrutura primária de Pln149a e peptídeos derivados foi realizada através da técnica de degradação de Edman e por experimentos de espectrometria de massas. Nesta etapa, estimou-se também o ponto isoelétrico dos peptídeos sintetizados.

\section{2.2.1 Degradação de Edman}

Um dos protocolos atualmente mais utilizados para se determinar a seqüência de resíduos de aminoácidos de uma cadeia polipeptídica inteiro é o método da Degradação de Edman (49), que consiste em marcar e remover sequencialmente um resíduo de aminoácido por vez a partir da extremidade N-terminal do polipeptídio, deixando todas as outras ligações peptídicas intactas. Tais análises de estruturais tiveram sua performance melhorada devido à automatização deste processo, em instrumentos denominados seqüenciadores, que mistura reagentes nas proporções apropriadas, separa os produtos, identifica-os e registra os resultados. Estes sequenciadores são utilizados acoplados com cromatógrafos líquidos de alta pressão (HPLC) que fazem a identificação dos resíduos liberados em cada ciclo de reação.

A análise da seqüência $\mathrm{N}$-terminal das cadeias polipeptídicas dos peptídeos foi realizada num seqüenciador automatizado de proteínas, junto ao laboratório da Profa. Dra. Heloisa S. S. de Araújo, do Departamento de Ciências Fisiológicas, da Universidade Federal de São Carlos.

Alíquotas (400 pmol) purificadas por RPC de Pln149a, Pln149S, Pln149(6-22), Pln149W(6-22), Pln149W e Pln149WS foram liofilizadas e ressuspendidas em água e solução de Sequa Brene (Sigma-Aldrich, MA, USA) (v/v), e posteriormente aplicadas sobre um disco de fibra especial (Wako, Osaka, Japão), previamente tratado com Sequa-Brene. O seqüenciamento foi realizado sob as condições recomendadas pelo fabricante. 


\section{2.2.2 Espectrometria de Massas}

A espectrometria de massas (MS, mass spectrometry) é uma técnica analítica muito usada para identificar compostos, quantificar materiais, elucidar algumas propriedades estruturais e químicas de moléculas, em química de proteínas, para determinar as razões isotópicas dos átomos na amostra (50), entre outras. As moléculas a serem analisadas por esta técnica, necessitam primeiramente ser ionizadas, ou seja, convertidas em íons por uma utilização de uma técnica de ionização. Uma das mais empregadas na determinação de massas moleculares é a ionização por eletropulverização ou electrospray (ESI MS), na qual a solução de interesse é bombeada num capilar metálico mantido a um potencial (positivo ou negativo). O campo elétrico leva a um acúmulo de carga na ponta do capilar, seguida pela emissão de gotículas com excesso de carga que passam por um processo de evaporação do solvente e fissão eletrostática que culmina com a expulsão dos íons para a fase gasosa. Esta técnica permite a determinação de moléculas com altas massas moleculares, uma vez que é capaz de produzir abundantemente íons multiplamente carregados. A outra técnica de ionização bem utilizada é a ionização em matriz assistida por laser (MALDI MS), na qual a cadeia polipeptídica é colocada numa matriz que absorve a luz. Com um pulso curto de laser, o polipeptídeo é ionizado e depois dessorvido da matriz para dentro de um sistema de vácuo.

Uma vez adquiridos os íons, a segunda etapa da técnica de MS é analisar as razões $\mathrm{m} / \mathrm{z}$ destes íons. Dentre os analisadores, o quadrupolo tem sido o mais comumente empregado em equipamentos comerciais de uso geral. Neste tipo de filtro, os íons são injetados paralelamente a quatro barras metálicas, às quais são aplicadas combinações de potenciais elétricos de corrente contínua (DC) e alternada (AC). A variação dos potenciais DC aplicados às barras metálicas faz com que somente íons com uma determinada relação $\mathrm{m} / \mathrm{z}$ tenham trajetórias estáveis e cheguem até o final do percurso (51).

Outro tipo de analisador é o TOF (Time of Flight), que se baseia no fato de que a diferença de massas entre os íons gerados, é a responsável pela diferença no tempo de vôo dos mesmos através do espaço entre a amostra e o detector, uma vez que a diferença de potencial ao qual estarão submetidos os íons é constante. Desta forma, quanto mais leve o íon, mais rápido este voará e atingira o detector em menor tempo.

A MS também é um método utilizado para seqüenciar cadeias polipeptídicas, o que confere a possibilidade de identificar proteínas desconhecidas. Tal informação provém da técnica conhecida como MS sequencial, ou MS/MS. Nesta técnica um polipeptídeo com 
determinada razão $\mathrm{m} / \mathrm{z}$ é selecionado num primeiro espectrômetro e, em seguida, fragmentado numa câmara de colisão, a maioria das quebras ocorre nas ligações peptídicas. Ao sair desta câmara, o íon passará por um segundo espectrômetro que medirá as razões $\mathrm{m} / \mathrm{z}$ dos fragmentos liberados, tornando possível a identificação de cada resíduo na sequencia polipeptídica.

Os peptídeos derivados de Pln149 foram analisados por MS para se determinar suas massas intactas e também checar a sequencia de aminoácidos em MS/MS. As amostras foram analisadas no espectrômetro ESI/TOF-MS junto ao laboratório do Prof. José César Rosa do grupo de Química de Proteínas do Hemocentro de Ribeirão Preto, e também no UPLC acoplado a um ESI/TOF-MS (Waters) do laboratório de Análise de Massas do Instituto de Química Avanzada de Catalunya em Barcelona.

Alíquotas dos peptídeos foram solubilizadas em uma mistura (1:1) de ACN e água milliQ e analisadas em cada espectrômetro.

\section{2.2.3 Ponto isoelétrico}

O cálculo teórico do ponto isoelétrico $(\mathrm{pI})$ de cada um dos peptídeos sintetizados foi realizado através do software Compute pI/MW for Swiss-Prot do site ExPASy Proteomics Server (52) que usa os valores de $\mathrm{pK}$ dos aminoácidos descritos em Bjellqvist et al. (53).

\section{2.3 Purificação dos peptídeos}

Após síntese e clivagem de cada um dos peptídeos análogos de $\operatorname{Pln} 149$, a purificação destas moléculas foi realizada por cromatografia de fase reversa em sistema High Performance Liquid Chromatography (HPLC) num aparelho analítico-semipreparativo marca Gilson (USA), com a coluna Vydac $\mathrm{C}_{18}$, ou então num cromatógrafo de alta e baixa pressão ÄKTA purifier system (GE Healthcare), com a coluna YMC-Pack Polymer $\mathrm{C}_{18}$.

As colunas foram previamente equilibradas com o solvente A (TFA 0,1\% em $\mathrm{H}_{2} \mathrm{O}$ ), e cada um dos peptídeos ( $1 \mathrm{mg}$ ) foi solubilizado neste solvente A, aplicados no cromatógrafo, e 
posteriormente eluídos num gradiente de 0 a $70 \%$ do solvente B (TFA 0,1\%, acetonitrila 90\% em $\mathrm{H}_{2} \mathrm{O}$ ) durante 40 minutos, sob um fluxo de $1 \mathrm{~mL} / \mathrm{min}$. A eluição foi monitorada em 220 $\mathrm{nm}$ e as frações correspondentes de cada amostra foram coletadas, diluídas em água e secas em sistema SpeedVac ou liofilizadas para os estudos posteriores.

\section{2.4 Ensaios de Atividade Biológica}

Devido ao grande número de funções que podem desempenhar dentro e fora de organismos vivos, os peptídeos tornaram-se uma classe de moléculas de crescente importância em bioquímica, química medicinal e fisiologia. Muitos peptídeos naturais apresentam diversas atividades biológicas diferentes, tais como regulação de ação hormonal $(54,55)$, interações do tipo enzima/substrato (56), citotoxicidade, indução de apoptose celular (57), interação do tipo antígeno/anticorpo (58), inibição de microorganismos (59). A fim de detectar as possíveis atividades biológicas de Pln149a, diferentes ensaios foram realizados com esta molécula.

\section{2.4.1 Atividade Hemolítica}

A atividade hemolítica de Pln149a e dos demais análogos foi investigada segundo o método descrito por Castro et al. (60) com algumas modificações. Resumidamente coletou-se, sangue humano e, em seguida, promoveu-se 3 lavagens com uma solução de PBS (pH 7.4) contendo $0.15 \mathrm{M} \mathrm{NaCl}$, na qual descartava-se o sobrenadante (incluindo série branca). Preparou-se, então, uma suspensão eritrócitos $1 \%$ em PBS. Cada um dos peptídeos foi diluído serialmente em tubos de vidro (partindo-se da concentração de $500 \mu \mathrm{M}$ até $1 \mu \mathrm{M}$ ), e estes foram incubados com a suspensão de hemácias a $37^{\circ} \mathrm{C}$ por 1 hora e centrifugados a 3000 g. O sobrenadante foi coletado e distribuído numa microplaca de 96 poços, onde o grau de hemólise foi avaliado espectrofotometricamente pela leitura da absorbância em $405 \mathrm{~nm}$ numa leitora de microplacas, fornecendo uma medida da liberação de hemoglobina das células vermelhas. 
A lise completa das hemácias (100\%) foi obtida com o uso de Triton X-100 e um controle com PBS foi definido com $0 \%$ de hemólise A porcentagem de hemólise foi calculada pela equação 8

$$
\%_{\text {hemolise }}=\frac{\left[A_{\text {Peptideo }}-A_{P B S}\right]}{\left[A_{\text {Triton }}-A_{P B S}\right]}
$$

\section{2.4.2 Inibição do crescimento de microorganismos}

A fim de melhor caracterizar o espectro de ação antimicrobiana de Pln149a, ação do peptídeo foi testada contra várias cepas bacterianas e fungos patogênicos. Além disso, foram investigados também, os peptídeos análogos: Pln149S, Pln149(6-22), Ac- Pln149(6-22), Noctil-Pln149(6-22) e Fmoc-Pln149(6-22) para que se pudesse comparar o efeito causado na atividade antimicrobiano devido às modificações presentes nos peptídeos.

Os ensaios de inibição do crescimento de bactérias e fungos patogênicos aqui descritos foram realizados na Universidade Federal do Ceará, no Laboratório de Ecologia Microbiana e Biotecnologia, sob a responsabilidade da Profa. Dra. Vânia Maria Maciel de Macedo, com a ajuda da doutoranda Denise Hissa.

\section{2.4.2.1 Ensaio Antibiograma}

O ensaio antibiograma foi realizado a fim de medir a susceptibilidade/resistência de alguns microorganismos à ação de $\mathrm{P} \ln 149 \mathrm{a}$ e formas modificadas. $\mathrm{O}$ ensaio procedeu-se conforme descrito pelo método de difusão em discos por Bauer e colaboradores (61). Suspensões de cada microorganismo em solução salina $(\mathrm{NaCl} 0.85 \%)$ foram ajustadas para uma concentração de $10^{7} \mathrm{UFC} / \mathrm{mL}$ (o que corresponde a uma absorbância de 0.100 em 600 $\mathrm{nm})$ e, posteriormente, foram semeados homogeneamente em placas de Petri contendo meio sólido. Em seguida, $15 \mu \mathrm{L}$ de cada peptídeo (a uma concentração de $1 \mathrm{mg} / \mathrm{mL}$ ) foram 
depositados sobre discos de papel de filtro (diâmetro5 $\mathrm{mm}$ ) que, em seguida, foram uniformemente espalhados sobre a placa. Dois discos em cada placa foram utilizados como controles. Um deles (positivo) continha antibiótico Tetraciclina (TET 30); e o outro, apenas água estéril. As placas foram incubadas a $38^{\circ} \mathrm{C}$ durante 24 horas, e a inibição do crescimento microbiano foi avaliada pela formação de halos de inibição ao redor dos discos.

Neste ensaio, foram testadas cepas de bactérias Gram (+), Gram (-) e leveduras. São elas: Bacillus subtilis ATCC 6633, Enterobacter aerogenes ATCC 13048, Klebisiella pneumonia ATCC 10031, Pseudomonas aeruginosa ATCC 9027, Staphylococcus aureus ATCC 25923, Salmonella choleraesius ATCC 10708, Staphylococcus aureus ATCC 6538, Pichia membranaefaciens, Candida tropicalis (efluente da LUBNOR), Candida albicans 14053, Candida crusei 6258, Lactobacillus sp L1, Lactobacillus sp L9, Lactobacillus sp L15, Lactobacillus sp L18. Todas estas cepas estão localizadas na micoteca/bacterioteca do laboratório de Ecologia Microbiana da Universidade Federal do Ceará.

Os meios de cultura sólidos utilizados foram o Lactobacilli para as bactérias lácticas; meio Mueller Hinton para as demais bactérias; e meio Sabouraud para as leveduras.

\section{2.4.2.2 Determinação da Concentração Inibitória Mínima (MIC)}

Os ensaios para determinar a MIC de Plantaricina 149 sintetico e demais análogos sobre diferentes microorganismos foram realizados com base no ensaio em meio líquido (62) com algumas modificações. Inicialmente, uma solução do peptídeo foi diluída seriadamente (1:1, 1:2, 1:4, etc.) em água estéril numa microplaca de 96 poços. Em seguida, uma suspensão de cada um dos microorganismos em meio de cultura teve sua turbidez ajustada para uma absorbância de $0.010 \mathrm{em} 600 \mathrm{~nm}\left(10^{6} \mathrm{UFC} / \mathrm{mL}\right)$. Esta suspensão foi adicionada a cada um dos poços numa proporção 1:1 (v/v) com o peptídeo.

Dois controles foram utilizados neste ensaio: um positivo, que continha a suspensão de bactérias e água no lugar do peptídeo; e um negativo, contendo a suspensão de bactérias e Formaldeído $0,4 \%$.

A microplaca foi incubada a $37^{\circ} \mathrm{C}$ por $24 \mathrm{~h}$, sendo realizadas leituras periódicas da absorbância em $630 \mathrm{~nm}$ a cada 6 h. Após o período de incubação, o crescimento/inibição do microorganismo foi estimado através da comparação da turbidez com a dos poços controle. A 
MIC foi tomada como a menor concentração do peptídeo capaz de reduzir o crescimento do microorganismo por $50 \%$ ou mais $\left(\mathrm{MIC}_{50}\right)$, após as $24 \mathrm{~h}$ de incubação.

No ensaio, foram utilizados $50 \mu \mathrm{L}$ dos peptídeos Pln149, Pln149S e demais análogos do grupo II a uma concentração inicial de $3 \mathrm{mg} / \mathrm{mL}$ e $50 \mu \mathrm{L}$ da suspensão do microorganismo. $\mathrm{O}$ ensaio foi realizado em duplicata com as cepas de Pseudomonas aeruginosa ATCC 9027, Staphylococcus aureus ATCC 25923. O meio de cultura utilizados foi o Caldo Mueller Hinton. Também foram avaliadas a atividade inibitória de Pln149a e Pln149S sobre Cândida albicans e Lactobacillus L18, partindo de uma concentração inicial do peptídeo de $1 \mathrm{mg} / \mathrm{mL}$ e utilizando os meio de cultura BHI (Brain Heart Infusion) e Lactobacilli MRS, respectivamente.

Após este ensaio, para verificar o mecanismo de ação de cada peptídeo, se bactericida ou bacteriostático, alíquotas $(5 \mu \mathrm{L})$ de cada um dos poços foram subcultivadas em placas de Petri contendo meio de cultura sólido, preparado na ausência do peptídeo. As placas foram incubadas a $37^{\circ} \mathrm{C}$, por 24 horas, e o crescimento observado através da presença ou ausência de colônias no local de depósito de cada alíquota.

\section{2.4.3 Atividade contra Saccharomices cerevisiae}

Uma colônia de $S$. cerevisiae foi utilizada para pré-inocular $1 \mathrm{~mL}$ do meio de cultura líquido Yeast Extract Peptone Dextrose (YEPD) que foi deixado crescer overnight, sob agitação de $200 \mathrm{rpm}$, a $30^{\circ} \mathrm{C}$. Após crescimento, uma pequena alíquota desta cultura $(10 \mu \mathrm{L})$ foi depositada em um frasco contendo Pln149a $(80 \mu \mathrm{M})$ e $5 \mathrm{~mL}$ do meio YEPD. Esta cultura teve sua turbidez monitorada após em $600 \mathrm{~nm} 16$ e 24 h de incubação. Um controle (meio de cultura na ausência do peptídeo) foi mantido sob as mesmas condições e monitorado neste intervalo de tempo.

\section{2.4.3.1 Microscopia Eletrônica de Varredura (MEV)}

Um ensaio de inibição do crescimento de leveduras foi observado por MEV a fim de observar possíveis alterações morfológicas na cultura de células remanescentes após a ação do 
peptídeo. As medidas de MEV foram realizadas no microscópio eletrônico de varredura Zeiss-DSM 960 da Fundação de Apoio a Física e Química do Instituto de Física de São Carlos.

O protocolo de preparação das amostras a serem visualizadas está descrito a seguir: Culturas frescas de Saccharomyces cerevisiae foram inoculadas em $500 \mu \mathrm{L}$ de meio de cultura YEPD na presença e na ausência do peptídeo Pln149a $(1 \mathrm{mg} / \mathrm{mL})$. Desta cultura, diferentes alíquotas foram tomadas ao longo do tempo de crescimento da levedura, em intervalos de 6, 12 e 24 h de incubação. Cada uma dessas alíquotas foi diluída em tampão PBS 0.1 M (pH 7,4) para um volume final de $1 \mathrm{~mL}$, e em seguida filtrada em membranas de acetato de celulose (poros de $0.45 \mu \mathrm{m}$ ). A membrana foi, então, lavada em $\mathrm{NaCl} 0,9 \%$ para remoção do excesso de amostra, e em seguida passou pelo processo de fixação do material retido pela sua incubação em tampão fosfato contendo glutaraldeído $2,5 \%$ por $12 \mathrm{~h}$, a $4{ }^{\circ} \mathrm{C}$. Ao final do processo, três outras lavagens da membrana em tampão fosfato foram realizadas.

A membrana passou ainda pelo processo de desidratação através da sua incubação em soluções de 50, 70, 80, 90, 95 e 100\% de etanol, seguida por secagem em dessecador overnight e deposição de $1 \mathrm{~mL}$ de HMDS sobre ela. Uma vez desidratada, a membrana foi montada sobre suporte apropriado para MEV (denominados stubs) para passar pelo processo de metalização, onde ocorre a impregnação com ouro, a fim de ser posteriormente observada no microscópio de varredura eletrônica sob um feixe de $25 \mathrm{kV}$.

\section{2.4.4 Inibição do crescimento de células tumorais}

Ensaios para avaliar a citotoxicidade de Pln149a, Pln149(6-22), Ac-Pln149(6-22), Fmoc-Pln149(6-22) e Noctil-Pln149(6-22) em células de cancêr de próstata da linhagem Du145 foram realizados no Departamento de Ciências Fisiológicas da Universidade Federal de São Carlos, sob a responsabilidade da Profa. Dra. Márcia Regina Cominetti.

Diferentes concentrações de cada um dos peptídeos (10, 50100 e $200 \mathrm{nM}$, e também $1,5,10$, e $20 \mu \mathrm{M}$ ) foram incubadas com células Du-145, na concentração fical de $5 \times 10^{4}$ células $/ 100 \mu \mathrm{L}$ em uma placa de 96 poços. A mistura foi incubada durante $1 \mathrm{~h}$ a $37^{\circ} \mathrm{C}$ em estufa contendo $5 \% \mathrm{CO}_{2}$ e em seguida adicionou-se o reagente MTT. A placa foi incubada 
por mais $4 \mathrm{~h}$ nas mesmas condições acima e em seguida lida em leitor de placa de ELISA com comprimento de onda de $595 \mathrm{~nm}$.

\section{2.5 Espectroscopia de dicroísmo circular (CD)}

O fenômeno de dicorísmo circular (CD, do inglês Circular Dichroism) é observado como propriedade de moléculas que possuem centros assimétricos (centros quirais). Estes centros são os responsáveis pela absorção diferenciada das componentes polarizadas da luz circular $(63,64)$.

A espectroscopia de CD em peptídeos e proteínas é uma ferramenta muito utilizada no estudo de mudanças conformacionais (sofridas devido a variações de solventes, temperatura e de $\mathrm{pH}$ ), na interação com ligantes e em ensaios de desnaturação e renaturação de proteínas $(65,66)$. Os principais centros quirais das cadeias polipeptídicas, os $\mathrm{C}_{\alpha}$, estão ao longo da cadeia principal, portanto, seus espectros de CD na região entre 180 e 260 nm (região do UVdistante) fornecem informações capazes de caracterizar e discriminar estruturas secundárias ( $\alpha$-hélice, fitas- $\beta$, voltas e estruturas não-ordenadas) presentes nestas moléculas $(67,68)$. A Figura 4 mostra os espectros de CD de proteínas compostas por diferentes tipos de estrutura secundária. 


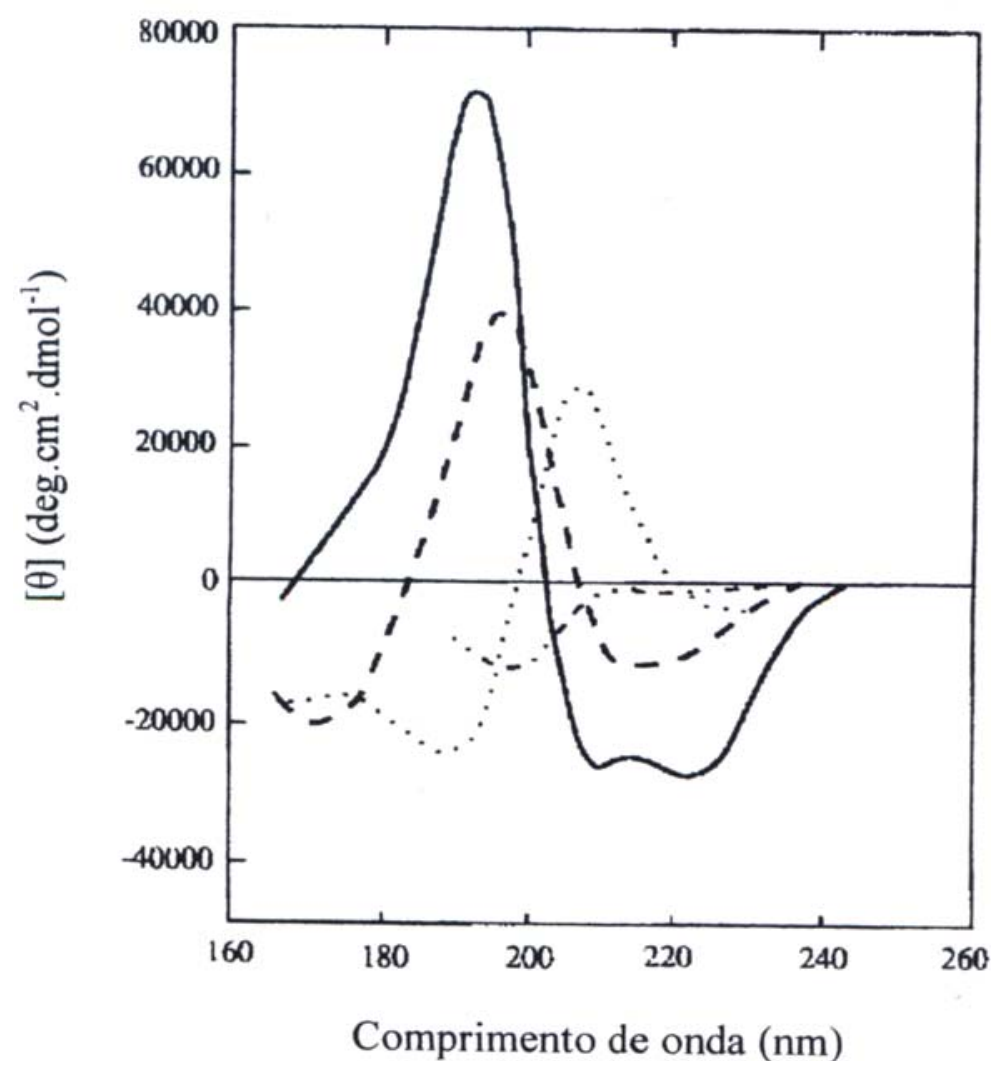

Figura 4 - Espectro de CD de vários tipos de estrutura secundária. Os espectros representam $\alpha$-hélice (一), folha- $\beta$ ( - - - ), voltas- $\beta(\cdots)$ e estrutura irregular ( ${ }^{\circ}$ - -). Modificada a partir de Kelly \& Price, 1997.

A estimativa do conteúdo das frações de estrutura secundária de uma proteína é feita com base num grupo de proteínas de referência que possuem estrutura secundária e espectros de CD conhecidos. Tal estimativa está apoiada na idéia que o espectro de CD de uma proteína qualquer pode ser descrito por uma combinação linear de todas as frações de estrutura secundária que a constitui. Com o auxílio de programas computacionais, que utilizam diferentes métodos de desconvolução, são extraídas as componentes comuns dos espectros de CD da proteína analisada e a porcentagem que as mesmas representam no espectro $(68,69)$. No entanto, dada a complexidade do espectro, a determinação quantitativa da estrutura secundária de uma proteína apenas por análise do espectro de CD é muitas vezes inviável.

\section{2.5.1 Peptídeos em solução aquosa}

Após processo de purificação, alíquotas de cada um dos peptídeos derivados de Pln149 foram diluídas em água e também em tampão Hepes $10 \mathrm{mM}, \mathrm{pH} 7.4,(0.2 \mathrm{mg} / \mathrm{mL})$ e seus 
espectros de dicroísmo circular foram registrados na faixa de 190 a $250 \mathrm{~nm}$ como uma média de 16 varreduras. Estas medidas foram realizadas em cubetas retangulares de quartzo com caminho óptico de $1 \mathrm{~mm}$, a $25^{\circ} \mathrm{C}$. Os espectros originais passaram pelo processo de subtração das contribuições do solvente, e pelo Filtro de Fourier, de modo a preservar as bandas típicas de cada espectro, por fim, os resultados foram expressos em elipticidade molar $(\theta)$.

As contribuições de estrutura secundária pelo espectro de CD das moléculas estudadas foram realizadas utilizando o pacote de desconvolução CDPro (68), com os programas Selcon3, Continll e CDSSTR, utilizando um grupo de proteínas de referência contendo 56 espectros de CD (70-72). Alternativamente, o conteúdo helicoidal ( $\left.f_{\text {helice }}\right)$ de cada espectro nas diferentes condições descritas nesta seção foi também estimado utilizando-se o tratamento de Chen (73), que se baseia no valor da elipticidade em $222 \mathrm{~nm}\left(\theta_{222 \mathrm{~nm}}\right)$ e no número de resíduos de aminoácidos (n) do peptídeo, segundo a equação:

$$
f_{\text {helice }}=\frac{\left[\theta_{222 n m}\right]}{-39500 \times(1-2.75 / n)}
$$

\section{2.5.2 Presença de Metanol}

O efeito da presença de metanol na estrutura secundária dos peptídeos foi investigado pela técnica de $\mathrm{CD}$, pela incubação de Pln149a $(0.2 \mathrm{mg} / \mathrm{mL})$ na presença de diferentes composições de Metanol (0, 5, 10, 20, 40, 50, 60, 80 e $90 \%)$ seguida pelo registro de cada espectro de CD e avaliação do seu conteúdo helicoidal.

\section{2.5.3 Presença de Carboidratos}

A fim de monitorar possíveis mudanças conformacionais na estrutura secundária de Pln149a quando na presença de carboidratos, o espectro de CD deste peptídeo $(0.2 \mathrm{mg} / \mathrm{mL})$ foi tomado quando incubado com: D-Glicose D-Galactose, D-Manose,, D-Maltose, D-Sacarose, a-metil-D-Manosídeo, N-acetil-D-Galactosamina, Carragena e Galactomanana. Todos os 
carboidratos foram utilizados numa concentração de $0.1 \mathrm{M}$ e os seus respectivos espectros de CD foram subtraídos do peptídeo.

\section{2.5.4 Presença de vesículas fosfolipídicas}

O estudo da interação de Pln149a com vesículas fosfolipídicas se deu com a construção de sistemas modelos de membrana, no qual diferentes fosfolipídios foram utilizados para uma melhor mimetização das membranas biológicas reais.

Devido a sua estrutura ser semelhante à de uma membrana celular, as vesículas fosfolipídicas representam os modelos de membrana mais utilizados. Neste sistema, as cadeias acil-graxas dos fosfolipídios interagem entre si para evitar o contato com a água, e se unem formando uma bicamada lipídica circular que apresenta em seu interior um conteúdo aquoso. Elas são classificadas de acordo com o tamanho (gigantes, grandes e pequenas) e com o número de bicamadas contém (uni ou multilamelares).

Para os ensaios de CD, vesículas unilamelares grandes (Large Unilamellar Vesicles, LUV) foram preparadas com cada um dos fosfolipídios: 1,2-Dipalmitoyl-sn-Glycero-3[Phospho-rac-(1-glycerol)] (DPPG), 1,2-Dipalmitoyl-sn-Glycero-3-Phosphocholine (DPPC), 1,2-Dipalmitoyl-sn-Glycero-3-[Phospho-L-Serine] (DPPS), 1-palmitoyl-2-oleoyl-glycero-3phospho-rac-glycerol (POPG), 1,2-Dipalmitoyl-sn-Glycero-3-Phosphoethanolamine (DPPE), 1,2-Dilauroyl-sn-Glycero-3-Phosphocholine ～(DLPC), 1,2-Distearoyl-sn-Glycero-3Phosphoethanolamine (DSPE) 1,2-Dimyristoyl-sn-Glycero-3-Phosphocoline (DMPC); todos adquiridos de Avanti Polar Lipds, Inc.

O protocolo utilizado para a preparação das LUVs está descrito a seguir. Cada um dos fosfolipídios foi solubilizado em clorofórmio, ou uma mistura de clorofórmio/metanol 4:1 $(\mathrm{v} / \mathrm{v})$, em tubos de vidros previamente limpos e secos. Este solvente foi vagarosamente evaporado sob um fluxo de $\mathrm{N}_{2}$, seguido por secagem em sistema SpeedVac ou liofilizadora por 2 horas, a fim de formar um filme fino na parte inferior do tubo. Posteriormente, o filme foi hidratado e ressuspendido até homogeneização em água ou solução tampão apropriado a fim de obter as vesículas multilamelares (MLVs) formadas pela incubação do tubo por $1 \mathrm{~h}$ numa temperatura acima da temperatura de transição de cada um dos fosfolipídios $\left(41^{\circ} \mathrm{C}\right.$, $41^{\circ} \mathrm{C}, 63^{\circ} \mathrm{C}, 54^{\circ} \mathrm{C}, 23^{\circ} \mathrm{C},-1^{\circ} \mathrm{C}$ e $74^{\circ} \mathrm{C}$ para DPPG, DPPC, DPPS, DPPE, DLPC, DMPC e 
DSPE, respectivamente). Após este tempo, as vesículas multilamelares foram levadas ao extrusor mantido sob temperatura controlada, utilizando membrana de corte de $100 \mathrm{~nm}$ (Avanti Polar Lipids) para a formação das vesículas unilamelares.

O monitoramento das interações entre estes sistemas biomiméticos com Pln149a e cada um dos demais peptídeos análogos sintetizados foi realizado numa razão peptídeo/lipídio 1:20 e o espectro de CD dos lipossomos foi subtraído dos espectros originais dos peptídeos com os lipossomos.

\section{2.5.4.1 Ensaio frente a variações de pH e força iônica}

Com o intuito de analisar as possíveis mudanças conformacionais que seriam induzidas em Pln149a por influência do $\mathrm{pH}$ e da força iônica do meio, bem como a influência destas variáveis na interação do peptídeo com vesículas fosfolipídicas, amostras de Pln149a $(0.15 \mathrm{mg} / \mathrm{mL})$ foram incubadas em soluções tamponadas de Acetato-Borato-Fosfato de Sódio $20 \mathrm{mM}$ de $\mathrm{pH}$ 3.0, 5.0, 7.0, 9.0 e 11.0 e também em soluções aquosas com diferentes quantidade de $\mathrm{NaCl}(0,50 \mathrm{mM}, 100 \mathrm{mM}, 250 \mathrm{mM}, 0.5 \mathrm{M}, 1 \mathrm{M}$ e $2 \mathrm{M})$ na ausência e na presença de vesículas de DPPG. Os espectros de CD foram tomados após $15 \mathrm{~min}$ de incubação do peptídeo nestas condições, à $25^{\circ} \mathrm{C}$.

\section{2.5.4.2 Vesículas mistas}

LUVs mistas de DPPG/DPPC nas razões molares de 1:3, 1:1 e 3:1 (mol/mol) foram preparadas do mesmo modo descrito anteriormente, de forma a promover a mistura dos fosfolipídios quando já solubilizados em clorofórmio, e seguindo com o mesmo protocolo de preparação dos lipossomos. Em seguida, os espectros de CD de Pln149a e Pln149S foram registrados após incubação com estas vesículas numa razão peptídeo/lipídio 1:20 (mol/mol). 


\section{2.5.5 Membranas de Leishmania}

O conteúdo total de lipídeos da membrana celular de células de Leishmania foi obtido por extração com o do detergente TritonX-100, no Departamento de Química da FFCLRPUSP sob responsabilidade do Prof. Dr. Pietro Ciancaglini, que gentilmente nos cedeu tal fração.

Em nosso, laboratório, este extrato lipídico foi solubilizado em clorofórmio e, em seguida, esta fração foi utilizada para a reconstrução de vesículas multilamelares em PBS (pH 7.4), que foram posteriormente sonicadas até a obtenção de uma solução transparentes.

Os espectros de CD de Pln149a $(0.2 \mathrm{mg} / \mathrm{mL})$ na presença destas vesículas de Leishmania foram registrados após incubação por 15 min.

\section{2.5.6 Dependência com a concentração de peptídeo}

A dependência da estrutura secundária do peptídeo Pln149a em função da concentração do peptídeo em solução aquosa foi verificada pela realização de medidas de dicroísmo circular com o peptídeo num intervalo de concentração de 50 a $400 \mu \mathrm{M}$ em água. As medidas foram realizadas como uma média de 8 varreduras, a $25^{\circ} \mathrm{C}$, em cubeta retangular de quartzo de caminho ótico de $1 \mathrm{~mm}$.

\section{2.6 Espectroscopia de fluorescência}

A espectroscopia de emissão de fluorescência estática é largamente utilizada no estudo de proteínas e peptídeos para fornecer informações relacionadas às vizinhanças dos grupos fluorescentes (fluorórofos naturais), que em proteínas são os aminoácidos aromáticos: Phe, Tyr e Trp (74). A fluorescência do resíduo de Trp é altamente sensível ao ambiente em que se encontra, portanto, monitorar suas alterações pelos parâmetros da espectroscopia de fluorescência, tais como posição do máximo de emissão $\left(\lambda_{\max }\right)$ e mudanças no rendimento 
quântico $\left(\phi_{\mathrm{F}}\right)$ devido à ação de solventes, ligantes e $\mathrm{pH}$, sugerem discretas mudanças conformacionais sofridas nas vizinhanças dos fluoróforos (75).

\section{2.6.1 - Peptídeos em solução aquosa}

As medidas de emissão de fluorescência intrínseca dos peptídeos foram realizadas no modo estático a $25{ }^{\circ} \mathrm{C}$. Cubetas retangulares de quartzo de $1 \mathrm{~cm}$ de caminho ótico foram utilizadas nas medidas. $\mathrm{O}$ espectro de emissão de fluorescência da solução de referencia foi subtraído dos espectros das amostras correspondentes.

Alíquotas de Pln149a $(0.1 \mathrm{mg} / \mathrm{mL})$ foram diluídas em água ou tampão Hepes $10 \mathrm{mM}$ ( $\mathrm{pH}$ 7.4), excitadas em $275 \mathrm{~nm}$ e tiveram o espectro de emissão de fluorescência monitorado no intervalo de 290-450 nm. Já para as amostras contendo o resíduo de W na seqüência primária (Plm149W, Pln149WS, Pln149W(6-22), Ac-Pln149W(6-22), Noctil-Pln149(6-22) e Fmoc-Pln149W(6-22)), a excitação se deu em $280 \mathrm{~nm}$ e a emissão de fluorescência foi monitorada no intervalo de $295-450 \mathrm{~nm}$.

\section{2.6.2 Ionização do estado excitado da Tirosina}

Embora o espectro de emissão de fluorescência da Tyr seja um espectro simples e anisotrópico (ou seja, não sensível a polaridade do meio em que se encontra), é importante reconhecer a possibilidade de ocorrer a ionização da Tyr no estado excitado, conhecida como a formação do íon Tirosinato.

A fim de monitorar este efeito, o espectro de emissão da Tyr de Pln149a foi monitorado quando o peptídeo foi incubado em concentrações crescentes $(0,0.1,0.5,1.0$ e $2.0 \mathrm{M})$ do tampão fosfato de potássio ( $\mathrm{pH}$ 7.0). A excitação foi realizada em $275 \mathrm{~nm}$ e a emissão foi monitorada de 290 a $450 \mathrm{~nm}$. 


\section{2.6.3 - Presença de Vesículas}

Pln149a foi previamente incubado com as LUVs constituídas de DPPC, DPPG, DPPS, DPPE, DSPE, DMPE, DLPC e seus espectros de emissão foram registrados no intervalo de 290-450 nm, com excitação da Tyr em $274 \mathrm{~nm}$, com o uso de um filtro de $295 \mathrm{~nm}$. Os análogos do grupo III foram investigados com lipossomos de DPPC e DPPG, nas mesmas condições descritas acima.

\section{2.6.4 Ensaios de Leakage}

Medidas de emissão de fluorescência foram também realizadas com lipossomos contendo uma sonda fluorescente encapsuladas em seu interior, a fim de se estudar como a interação com o análogo sintético de Plantaricina149 afeta a permeabilidade desses lipossomos, permitindo ou não que as sondas encapsulados fossem diluídas no meio externo.

A preparação destes lipossomos é descrita a seguir. Uma concentração inicial de $5 \mathrm{mM}$ de fosfolipídio foi solubilizada numa mistura de clorofórmio/metanol (2:1) num frasco de vidro âmbar. Os solventes foram evaporados sob fluxo moderado de $\mathrm{N}_{2}$, e o tubo foi submetido à liofilização por 1 hora a fim de eliminar qualquer fração dos solventes orgânicos. Em seguida, o filme foi ressuspendido em tampão Hepes $5 \mathrm{mM}(\mathrm{pH}$ 7.4) contendo $\mathrm{NaCl} 20$ $\mathrm{mM}$ e as sonda ANTS $12.5 \mathrm{mM}$ e o supressor de fluorescência DPX $45 \mathrm{mM}$. Esta mistura foi agitada em vortex, até o desaparecimento da película do lipídio da parede do tubo, e posteriormente levada a um ultrasonicador de banho por $5 \mathrm{~min}$.

A desestabilização das lamelas concêntricas foi realizada submetendo as MLVs a uma serie de 10 ciclos de congelamento e descongelamento, onde o tubo de vidro foi incubado em temperaturas baixa, como a de um banho de gelo seco e acetona, e rapidamente trocado a temperatura por volta de $55{ }^{\circ} \mathrm{C}$. Os lipossomos unilamelares foram obtidos pelo processo de extrusão através de membranas de policarbonato com poros de $100 \mathrm{~nm}$ (Nucleopore).

O excesso das sondas não encapsuladas foi eliminado por uma cromatografia de exclusão molecular em uma coluna Sephadex G-75 empacotada com dimensões aproximadamente 20x1cm, e previamente equilibrada com tampão Hepes 5 mM (pH 7.4) 
contendo $100 \mathrm{mM}$ de $\mathrm{NaCl}$, que teve sua osmolaridade aferida em um osmômetro. Os lipossomos foram coletados, e a determinação da concentração de lipídios foi realizada de acordo com o protocolo de McClare (76).

O ensaio foi realizado a fim de avaliar os efeitos de permeabilização dos peptídeos Pln149a e Pln149S, adicionando diferentes concentrações dos peptídeos a uma população de lipossomos de DPPG, POPG e DPPC:DPPC (1:1) de concentração final de $0.1 \mathrm{mM}$ em cubetas de $1.5 \mathrm{~mL}$, de caminho ótico de $1 \mathrm{~cm}$, a $25^{\circ} \mathrm{C}$, sob agitação constante. As amostras foram excitadas em $355 \mathrm{~nm}$ e a emissão de fluorescência foi monitorada em $452 \mathrm{~nm}$ ao longo do tempo, no fluorímetro modelo AMINCO-Bowmann Serie 2 Luminescence Spectrometer.

A porcentagem de liberação dos conteúdos vesiculares (\% \%ib) foi calculada usando a equação (3):

$$
\%_{L i b}=\frac{\left(F-F_{0}\right)}{\left(F_{100}-F_{0}\right)} \times 100
$$

onde $F_{0}$ é a intensidade de fluorescência das LUVs sozinhas,

F é a intensidade de fluorescência após a incubação com o peptídeo,

e $F_{100}$, a intensidade de fluorescência após a adição de $10 \mu \mathrm{L}$ de TritonX-100 10\%.

\section{2.6.5 Titulação do triptofano}

A vizinhança do resíduo de Trp incorporado aos peptídeos Pln149W e Pln149WS foi monitorada a fim de se obter as isotermas de união que permitem determinar as constantes de partição destes peptídeos às LUVs. O ensaio consistiu em medir o espectro de emissão de fluorescência intrínseca destes peptídeos, e em seguida detectar as mudanças sofridas no espectro (deslocamento $\lambda_{\text {máx }}$ e variação da intensidade) ao adicionar os lipossomos e aumentar gradativamente a relação lipídio/peptídeo.

Alíquotas de cada um dos peptídeos em tampão Hepes 5 mM (pH 7.4) com concentração de $1 \mu \mathrm{M}$ foram excitadas em $295 \mathrm{~nm}$ e os espectros de emissão foram registrados no intervalo de 310 a $450 \mathrm{~nm}$. Vesículas unilamelares grandes (100 nm) de DPPG foram preparadas no mesmo tampão Hepes, e adicionadas a cada uma das amostras a fim de 
atingirem relações molares (lipídio:peptídeo) de 25:1, 50:1, 100:1, 200:1, 300:1, 400:1 e 500:1. A dosagem dos lipídios foi realizada através da quantificação dos fosfatos (76). Os espectros de fluorescência foram tomados após 5 minutos de incubação, a $25^{\circ} \mathrm{C}$, sob agitação constante.

Neste mesmo ensaio, foram registrados os espectros de fluorescência, nas mesmas condições descritas, substituindo-se o peptídeo por um derivado solúvel do triptofano Nacetil-triptofanamida (NATA), que tem máximo de emissão centrado em 350-355 nm, e este não se desloca ao se incorporar as LUVs (75). Outras medidas foram também realizadas em uma amostra contendo apenas os lipossomos. Estes dois controles permitiram minimizar os efeitos de dispersão da luz e diluição da amostra.

As constantes de partição dos peptídeos foram obtidas através do monitoramento do comprimento de onda em $350 \mathrm{~nm}$ dos espectros de emissão obtidos. Estes dados experimentais foram ajustados na equação hiperbólica a seguir (77):

$$
\mathrm{F} / \mathrm{F}_{0}=\frac{1+[\mathrm{L}]\left[\left(\mathrm{F}_{\max } / \mathrm{F}_{0}\right)-1\right]}{\mathrm{k}+[\mathrm{L}]}
$$

onde F é a intensidade de fluorescência em cada concentração de lipídio,

$\mathrm{F}_{0}$ é a intensidade de fluorescência na ausência dos lipossomos,

[L] é a concentração total do lipídio,

$F_{\max }$ é a intensidade de fluorescência máxima,

k é a constante de união aparente.

A constante de ligaçao aparente $\mathrm{k}$ foi aplicada na equação (4), para se obter a constante de ligação real $\mathrm{K}$,

$$
\mathrm{K}=\mathrm{W} / \mathrm{k}
$$

onde W é a concentração molar da água (55.3 M).

Para cada peptídeo se obteve um valor determinado de $\mathrm{K}$, o qual se utilizou para determinar a fração unida de cada peptídeo aos lipossomos $\left(\mathrm{F}_{\mathrm{x}}\right)$ :

$$
\mathrm{F}_{\mathrm{x}}=\mathrm{K}[\mathrm{L}] / \mathrm{W}+(\mathrm{K}[\mathrm{L}])
$$

onde [L] é a concentração total do lipídio, e

W é a concentração molar da água. 


\section{2.7 Estudo de projecão em estrutura helicoidal}

O conhecimento da tendência de formação de hélices na cadeia polipeptidica pode fornecer informações importantes sobre sua estrutura/função, pois resíduos em estrutura helicoidais constituem um dos elementos responsáveis pela manutenção da estabilidade da estrutura protéica. Um dos arranjos simples que a cadeia polipeptídica pode assumir, considerando a rigidez da ligação peptídica, é uma estrutura helicoidal, tal como a de uma $\alpha$ hélice, fazendo o uso máximo do numero de ligações de hidrogênio internas.

A projeção da cadeia polipeptídica num arranjo conhecido como Helical Wheel é uma ferramenta útil para o estudo de $\alpha$-hélices. A projeção num formato de círculo representa uma vista ao longo do eixo central da hélice, com as posições dos aminoácidos numeradas de 1 ao resíduo $\mathrm{n}$. As cores dos resíduos indicam sua natureza química de cada resíduo (hidrofóbico, não carregado, ácido; ou básico). As projeções helicoidais de Pln149a e dos demais peptídeos análogos em Helical Wheel foram realizadas a fim de monitorar a ocorrência de regiões com diferentes propriedades no peptídeo.

\section{2.8 Estudos de Tensão Superficial e Elasticidade}

A cinética de adsorção de Pln149 sobre monocamadas lipídicas foi realizada através de medidas de tensão superficial utilizando o método de análise da gota pendente, no qual utiliza-se a solução de interesse para promover a formação de uma gota, cujo formato é determinado por uma combinação de efeitos da tensão superficial e ação gravitacional. As forças superficiais tendem a formar gotas esféricas, enquanto o efeito da gravidade tende a alongar a gota, conforme mostrado na Figura 5. Para as análises, empregou-se o método de análise do perfil eixo-simétrico da gota (ADSA) num tensiômetro automático OCA-20 contendo acessório de oscilação ODG-20. Estas medidas foram realizadas no laboratório de Físico-Química de Superfícies da FFCLRP da Universidade de São Paulo sob a responsabilidade da Profa. Dra. Maria Elizabeth D. Zaniquelli, com a Pos-doutoranda Thatyane Nobre.. 


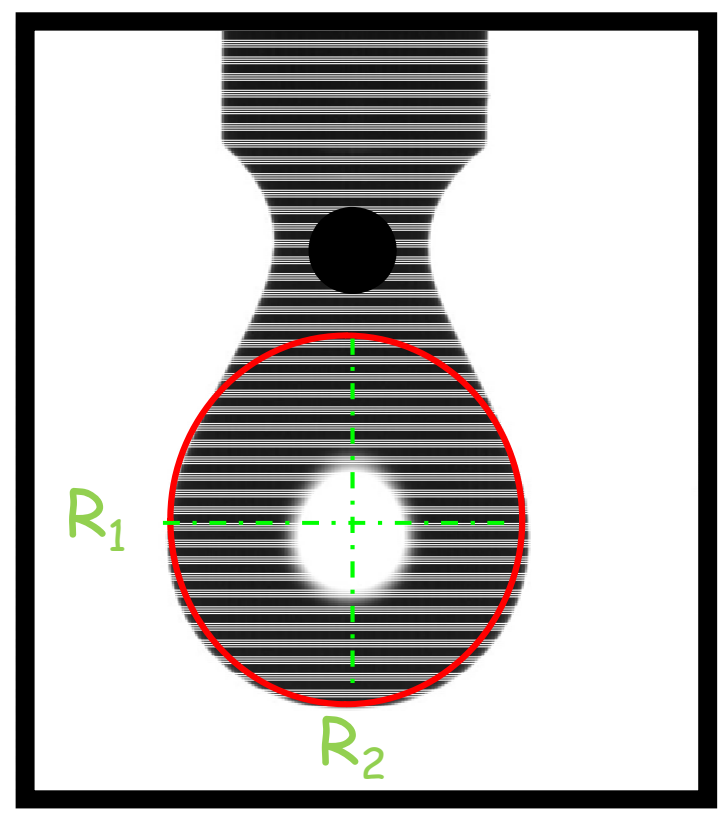

Figura 5 - Imagem em tempo real da gota pendente. Imagem adquirida pela câmera CCD da gota formada na extremidade da seringa, mostrando os raios $\left(\mathrm{R}_{1}\right.$ e $\left.\mathrm{R}_{2}\right)$ que determinam seu formato

A determinação da tensão superficial se dá através da digitalização da imagem e da análise do perfil da gota, quadro a quadro. De modo a ajustá-la à equação (7) de YoungLaplace (78), nas condições de equilíbrio para fluidos homogêneos separados por uma interface:

$$
\Delta \mathbf{P}=\left(\rho_{1}-\rho_{a}\right) \mathbf{g} \mathbf{h}=\left(\gamma / \mathbf{R}_{1}\right)+\left(\gamma / \mathbf{R}_{2}\right)
$$

onde $\mathrm{R}_{1}$ e $\mathrm{R}_{2}$ são os dois raios principais de curvatura da gota,

$\Delta \mathrm{P}$ corresponde à diferença de pressão entre o interior e a parte externa da gota;

g é aceleração da gravidade,

h é a altura da coluna líquida na gota, e;

$\rho_{1}$ e $\rho_{\mathrm{a}}$ são as densidades da fase líquida e do ar, respectivamente. 


\section{2.8.1 Peptídeo}

A tensão superficial de $\operatorname{Pln} 149 \mathrm{a}(10 \mu \mathrm{M})$ sozinho em água foi medida por $15 \mathrm{~min}$, numa gota pendente formada na superfície da agulha de uma seringa acoplada a uma bomba de injeção. Análises do formato dessa gota foram realizadas por filmagem com uma câmara CCD acoplada ao sistema, no qual um software com processo de disparo programado de filmagem captou a formação e as possíveis deformações do formato da gota.

\section{2.8.2 Monocamadas}

Para estes experimentos, foram utilizadas diferentes concentrações de Pln149 em água (de 0.1 a $10 \mu \mathrm{M}$ ) para formar a gota pendente. Sobre a superfície desta gota, uma pequena fração da solução do fosfolipídio de interesse foi suavemente depositada, com o auxílio de uma seringa de vidro, a fim de gerar uma monocamada fosfolipídica homogênea, de modo que as cabeças polares dos lipídios ficassem voltadas para o interior da gota e as caudas hidrofóbicas, voltadas para a interface com o ar. Desta maneira, o peptídeo em solução na gota poderia facilmente interagir com as cabeças polares negativamente carregadas do fosfolipídio. Monocamadas lipídicas de DPPG, DPPC e também da mistura de DPPG/DPPC nas razões de 1:3, 1:1, 3:1 (mol/mol) foram formadas sobre a superfície da gota. Os fosfolipídios foram inicialmente solubilizados em uma mistura de clorofórmio/metanol (4:1) para uma concentração final de $0.1 \mathrm{mM}$.

Inicialmente, promoveu-se a expansão da gota até atingir uma pressão superficial de aproximadamente $30 \mathrm{mN} / \mathrm{m}$, a fim de corresponder ao empacotamento das biomembranas (79). As subseqüentes mudanças na tensão superficial, devido à adsorção do peptídeo foram medidas com o tempo.

Após a tensão superficial ter alcançado o equilíbrio, foram realizados experimentos para monitorar a elasticidade superficial dilatacional, utilizando-se de um sistema de oscilação de freqüência que aplicava uma oscilação periódica na gota de $0.1 \mathrm{~mm}$ de amplitude, com variação relativa de área $(\Delta \mathrm{A} / \mathrm{A})$ de $5.5 \%$. As imagens da gota foram também gravadas com a 
câmera, e, ao final do experimento, o software recuperou as imagens e calculou os valores de área e o valor de elasticidade superficial correspondentes.

\section{2.9 Estudos de Ressonância Plasmônica de Superfície}

Quando um feixe de luz passa de um material com maior índice de refração para um material com menor índice de refração, haverá uma parcela da luz que será refletida na interface dos dois meios. Quando o ângulo de incidência do feixe de luz na interface dos meios $(\theta)$ for maior que um ângulo crítico, então a luz será totalmente refletida, ocorrerá reflexão interna total, conforme ilustrado na Figura 6A. Se a superfície do vidro for coberta com um filme fino de um metal nobre (por exemplo, o ouro), esta reflexão não será total. Parte da luz será "perdida" para o filme metálico. Deve haver então, um segundo ângulo maior que o ângulo crítico em que essa perda é maior, e em que a intensidade da luz refletida alcança um mínimo ou um “dip”. Este ângulo é chamado de ângulo de ressonância plasmônica de superfície $\left(\theta_{\mathrm{SPR}}\right)$. Ele é uma conseqüência da oscilação de elétrons que se propagam (ou plasmas) na superfície do filme de metal (Figura 6B).

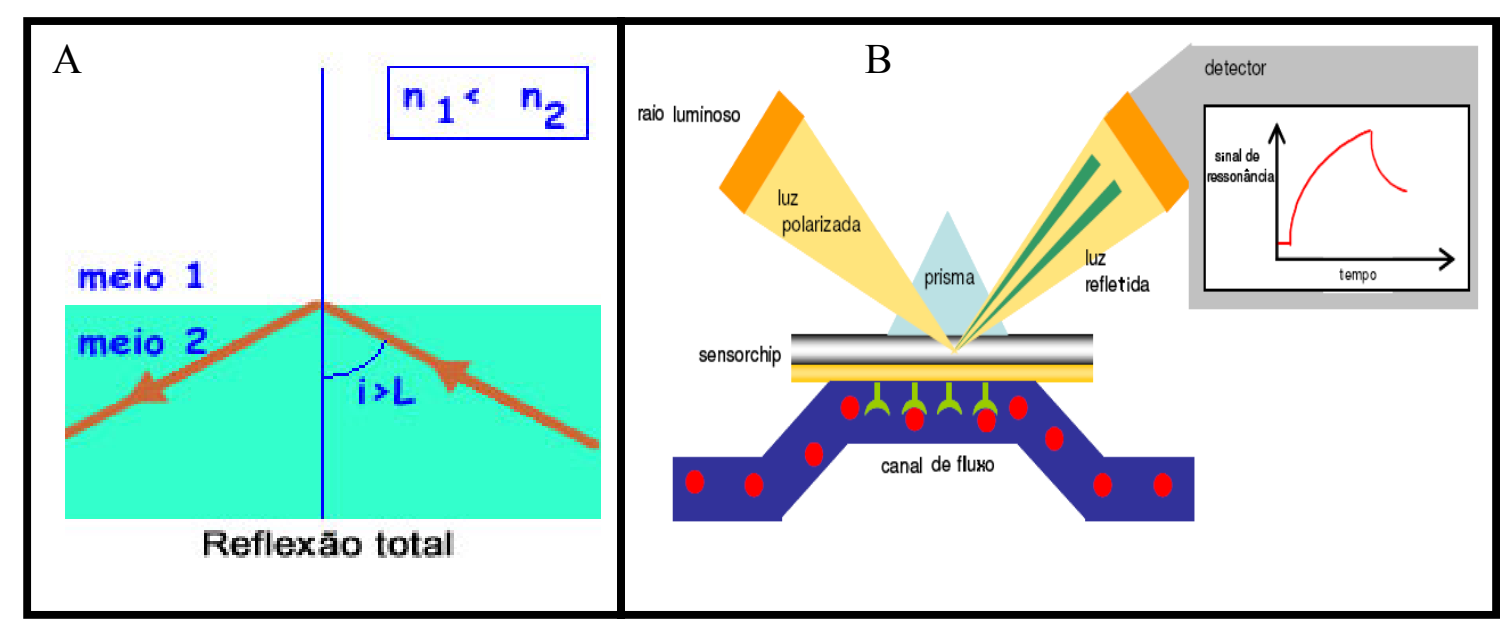

Figura 6 - Reflexão total interna (A), e SPR em sistema BIACORE (B). O feixe de luz parte do meio 2, que possui maior índice de refração, num determinado ângulo crítico ocorrerá a reflexão total do feixe. No sistema Biacore, o fenômeno de SPR é monitorado numa interface óptica constituída por um sensorchip e o sistema microfluidico.

Desde a introdução da tecnologia de biosensores baseada nesse fenômeno de Ressonância Plasmônica de Superfície, que se deu logo no início dos anos 90, tal ferramenta é 
utilizada para estudar uma grande variedade de interações, como por exemplo do tipo, antígeno-anticorpo, proteína-proteína, DNA-proteina, lipídeo-proteína, etc, pois uma de suas grandes vantagens é permitir a visualização em tempo real da interação que ocorre entre duas biomoléculas sem a aplicação de um marcador específico.

No estudo da interação de Pln149a com as vesículas fosfolipídicas pela tecnologia de biosensores, utilizou-se o instrumento BIAcore $X^{\circledR}$ (BIACORE AB, Upsala, Suécia), que monitora de forma precisa a interação entre uma espécie ligada a superfície de um sensor e outra que circula em solução, através de medidas de mudanças da massa adsorvida na superfície do sensorchip por medidas no índice de refração da interface da camada sensorfluido (80).

Um sensorchip é criado pela aplicação de uma fina camada de ouro (por volta de 50 $\mathrm{nm}$ ) numa superfície de vidro (substrato). Sobre essa camada de ouro, nos tipos mais comuns de sensorchip, está uma matriz hidrofóbica com 2-3\% de grupos de carboximetil-dextrana, resultando numa camada de interação de aproximadamente $100 \mathrm{~nm}$ de espessura. Esta matriz representa um meio compatível com as interações biomoleculares e permite a imobilização de um grande numero de ligantes com baixos níveis de ligação inespecífica.

Uma das moléculas a ser investigada, é imobilizada sobre o sensorchip a fim de criar uma superfície de reconhecimento específico, esta molécula é denominada ligante. A imobilização do ligante se dá através da ativação dos grupos carboxil-dextrana por reagentes apropriados, seguida pela ligação covalente do ligante com a camada de interação do sensorchip. Uma solução da outra biomolécula a ser investigada, chamada de analito, passará sobre este sensorchip e vai interagir com o ligante. A resposta desta interação, devido a formação do complexo ligante-analito resulta no acúmulo gradativo de massa na superfície do sensorchip, promovendo a mudança do índice de refração do meio, e em conseqüência a mudança no ângulo $\theta_{\mathrm{SPR}}$. Este ângulo é medido em unidades de ressonância (RU), onde 1000 RU correspondem a uma variação angular de aproximadamente $0.1^{\circ}(81)$.

Se um dado analito não interage com o ligante, a mudança no ângulo SPR na cela onde o ligante está imobilizado e na cela de referência (constituída apenas de grupos carboximetil-dextrana) serão iguais, o que resulta numa resposta em RU nula quando da subtração dos dois valores, indicando que não ocorreu ligação. Para muitas proteínas, a ligação de cerca de $1 \mathrm{ng} / \mathrm{mm}^{2}$ de proteína na superfície de dextrana é necessária para gerar um sinal de 1000 RU. No entanto, a relação exata entre RU e nanogramas de material ligado varia com o índice de refração da molécula. 
Medidas de SPR foram realizadas utilizando o fosfolipídio DPPG imobilizado em dois sensorchips comercialmente disponíveis pela BIACORE: HPA e L1. O sensorchip HPA consiste em moléculas de auto-organizadas alcanotiol que foram covalentemente acopladas a superfície de ouro do sensorchip. Esse chip é usado para preparar bicamadas lipídicas híbridas, pela fusão dos lipossomos sobre a superfície hidrofóbica formada pelos alcanotióis. Uma conseqüência da ligação covalente da camada de alcanotiol na superfície do chip HPA é a restrição da inserção de peptídeos e proteínas integrais dentro da bicamada. Desse modo, a fim de fornecer um modelo experimental mais apropriado para a caracterização das interações peptídeo-membrana, o sensorchip L1 foi introduzido para mimetizar mais eficazmente a estrutura fluida da bicamada da membrana celular, e também poder aprimorar a facilidade de reparação do modelo de membrana pelas análises de SPR. O sensorchip L1 é composto de uma fina camada de dextrana modificada com compostos lipofílicos sobre uma superfície de ouro, onde a bicamada lipídica pode ser preparada pela captura dos lipossomos (82). A Figura 7 ilustra o esquema me imobilização dos fosfolipídios na superfície dos chips HPA e L1.

(a) Sensor Chip HPA

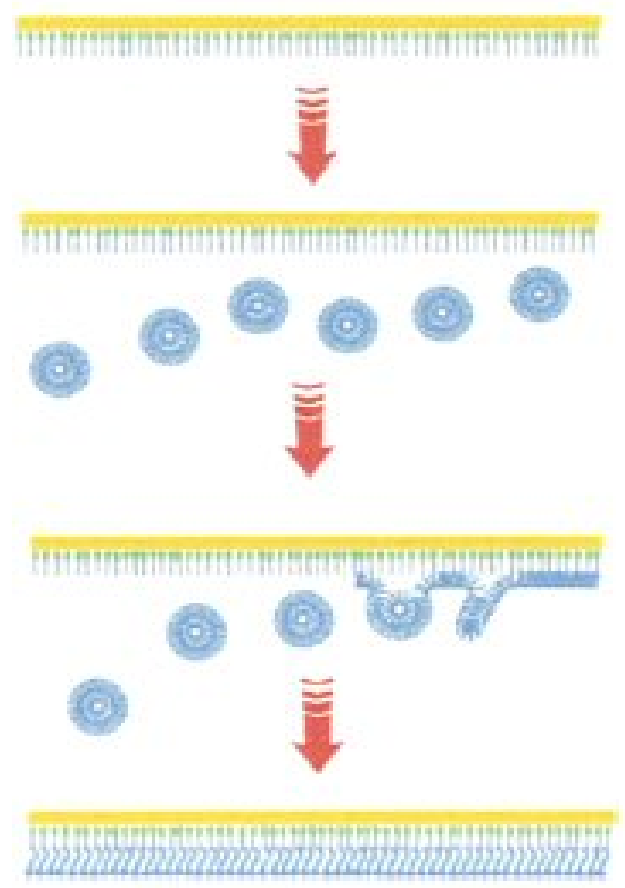

(b) Sensor Chip L1

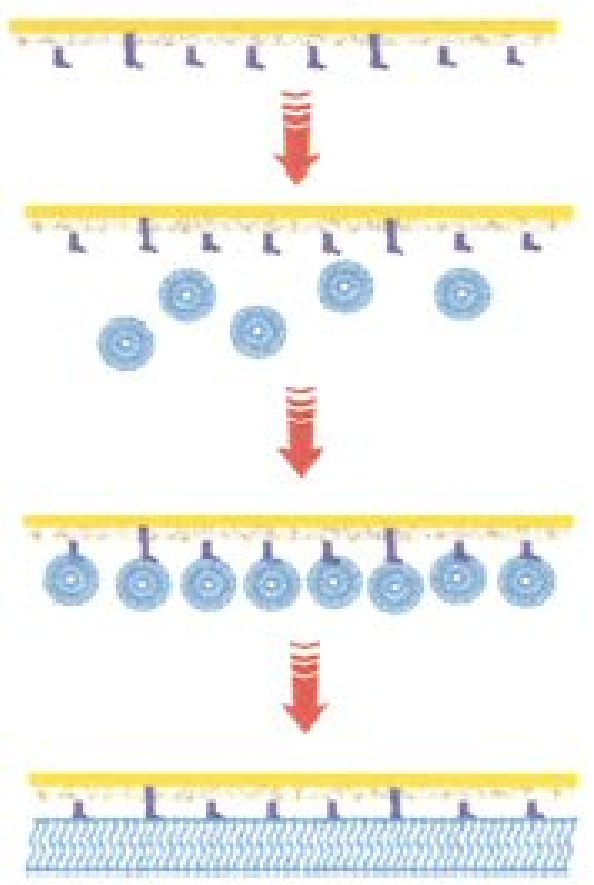

Figura 7 - Imobilização de fosfolipídios nos chips HPA e L1. Os lipossomos injetados sobre a superfície do sensorchip HPA são reconstruídos em monocamadas, resultando numa bicamada híbrida do fosfolipídio com o alcanotiol covalentemente ligado ao chip (a). Enquanto na superfície do sensorchip L1, os lipossomos são capturados por resíduos hidrofóbicos e constituem uma bicamada lipídica sobre a superfície do chip (b). 


\section{2.9.1 Sensorchip HPA}

A reconstrução da monocamada de DPPG na superfície do chip HPA foi realizada a $25^{\circ} \mathrm{C}$, utilizando o tampão Hepes $10 \mathrm{mM}(\mathrm{pH}$ 7.4) com $\mathrm{NaCl} 150 \mathrm{mM}$ e $1 \mathrm{mM}$ de EDTA como tampão de corrida. Inicialmente, as duas celas da superfície do sensorchip HPA foram lavadas com uma injeção de OGP $40 \mathrm{mM}$, um detergente não-iônico, sob um fluxo de 5 $\mu \mathrm{L} / \mathrm{min}$ durante 5 min. Em seguida, LUVs (de diâmetro de $100 \mathrm{~nm}$ ) de DPPG (1 mM), preparadas no mesmo tampão Hepes, foram injetadas sobre uma das celas do chip por 60 min, sob um fluxo de $1 \mu \mathrm{L} / \mathrm{min}$. O fluxo foi então aumentado para $100 \mu \mathrm{L} / \mathrm{min}$, durante $10 \mathrm{~min}$, para remover qualquer estrutura multilamelar, e ainda em seguida, uma injeção de $\mathrm{NaOH} 4$ $\mathrm{mM}$ de 1 min foi realizada nas duas celas, sob um fluxo de $5 \mu \mathrm{L} / \mathrm{min}$. Por fim, uma injeção de albumina sérica bovina (BSA, $1.5 \mu \mathrm{M}$ ) em tampão Hepes foi realizada nas duas celas, a fim de cobrir a extensão do chip. O sinal de SPR da cela que não recebeu a injeção de lipossomos foi subtraído do sinal de SPR da cela que continha a monocamada de DPPG imobilizado.

Soluções do peptídeo Plantaricina 149a foram preparadas em tampão Hepes (pH 7.4) em concentrações variando de 1.0 a $8.0 \mu \mathrm{M}$. Cada uma dessas soluções foram injetadas no sistema para monitorar sua interação com a monocamada de DPPG reconstruída na superfície do chip sob um fluxo de $20 \mu \mathrm{L} / \mathrm{min}$, durante $10 \mathrm{~min}$, e então a superfície do chip foi lavada por mais 10 min com o tampão Hepes sob o mesmo fluxo, a fim de promover a dissociação do peptídeo da monocamada do chip. Uma solução de regeneração, $\mathrm{NaOH} 4 \mathrm{mM}$, foi injetada por 1 min na superfície do chip para fazer com que o sinal de SPR voltasse a linha de base, quando necessário. A eliminação da monocamada da superfície do chip foi promovida por uma nova injeção de OGP $40 \mathrm{mM}$ durante $5 \mathrm{~min}$, fazendo com que o sinal de SPR voltasse para próximo de 0 unidades de ressonância (RU).

\section{2.9.2 Sensorchip L1}

A imobilização das vesículas de DPPG na superfície do sensorchip L1 se deu a $25^{\circ} \mathrm{C}$, com o tampão Hepes 10 mM (pH 7.4) com NaCl 150 mM e 1 mM de EDTA como tampão de corrida. Uma injeção de OGP $40 \mathrm{mM}$, sob um fluxo de $5 \mu \mathrm{L} / \mathrm{min}$, durante $5 \mathrm{~min}$, lavou as 
duas celas do chip. Logo, LUVs (de diâmetro de $100 \mathrm{~nm}$ ) de DPPG (1 mM) foram injetadas sobre uma das celas do chip por $50 \mathrm{~min}$, sob um fluxo de $1 \mu \mathrm{L} / \mathrm{min}$ a fim de serem capturadas pelos compostos hidrofóbicos covalentemente ligados a superfície do chip L1, e formarem uma bicamada lipídica sobre a superfície do chip. Posteriormente, o fluxo foi aumentado para $100 \mu \mathrm{L} / \mathrm{min}$, durante $10 \mathrm{~min}$, seguido de uma injeção de $\mathrm{NaOH} 4 \mathrm{mM}$ nas duas celas por 1 min, sob um fluxo de $5 \mu \mathrm{L} / \mathrm{min}$. Por fim, uma injeção de BSA (1.5 $\mu \mathrm{M})$ em tampão Hepes foi realizada nas duas celas, a fim de cobrir a extensão do chip na cela que não recebeu a injeção das LUVs.

Pln149a em tampão Hepes (variando de 0.5 a $16 \mu \mathrm{M}$ ) foi injetada no sistema, e sua interação com a bicamada de DPPG reconstruída na superfície do chip foi monitorada sob um fluxo de $20 \mu \mathrm{L} / \mathrm{min}$, durante injeções de $10 \mathrm{~min}$. Logo depois superfície do chip foi lavada com o tampão de corrida e a dissociação do peptídeo da bicamada do chip foi monitorada por mais $10 \mathrm{~min}$.

\section{2.10 Ensaios de calorimetria}

A termodinâmica da interação entre peptídeo e membranas é um campo amplo que depende da natureza química dos lipídeos, dos peptídeos, dos carboidratos envolvidos e também da natureza do processo a ser investigado. A fim de simplificar esta interação, os sistemas modelos de membrana foram mais uma vez utilizados para estudar a interação de Pln149a com vesículas fosfolipídicas.

\section{2.10.1 Calorimetria de Varredura Diferencial (DSC)}

O estudo das transições de fase de gel para líquido-cristalino de uma vesícula fosfolipídica proporciona um método valioso para caracterizar as propriedades do estado de fluidez das membranas biológicas. Na técnica de DSC, os parâmetros termodinâmicos relacionados a esta transição são monitorados. Um deles é a temperatura em que essa transição ocorre, denominada Tm (temperature melting), e representa o ponto da curva onde o 
calor absorvido é máximo. Outro parâmetro, é a variação entálpica do processo $(\Delta \mathrm{H})$, que se calcula a partir da área sob a curva, tomando a linha de base como limitante. Ainda outro parâmetro termodinâmico que se utiliza é a largura de meia altura do pico de absorção de calor, representado por $\Delta \mathrm{T}_{1 / 2}$, este é a medida da largura do pico em unidades de temperatura.

Ensaios de DSC foram realizados com Pln149 e Pln149S em tampão Hepes 5 mM (pH 7.4) nas concentrações de $5,50,125,250,375$ e $500 \mu \mathrm{M}$ na presença de $6 \mathrm{mM}$ de vesículas de DPPG, num intervalo de temperatura de 15 a $70{ }^{\circ} \mathrm{C}$, com uma taxa de aquecimento de $1,5^{\circ} \mathrm{C} / \mathrm{min}$, no calorímetro Seratam do IQAB-CSIC, a fim de se estimar o coeficiente de partição $(K)$ do peptídeo entre a solução e a membrana lipídica, usando a equação abaixo (83):

$$
-\Delta \mathrm{T}=\frac{\mathrm{RT}_{\mathrm{m}, 0}^{2}}{\Delta \mathrm{H}} \frac{\mathrm{K}}{55.5+\mathrm{C}_{\mathrm{L}} \mathrm{K}} \mathrm{C}_{\mathrm{A}}^{0}
$$

onde R é a constante universal dos gases;

$\mathrm{T}_{\mathrm{m}, 0}$ é a temperatura de transição das vesículas puras;

$\Delta \mathrm{H}$ corresponde ao valor de entalpia do lipídio puro;

$C_{L}$ é a concentração total do lipídio

$C_{A}^{0}$ é a concentração total do peptídeo em mol\%

Dessa forma, os valores de $-\Delta T=T_{m}-T_{m, 0}$ são plotados contra a concentração molar do peptídeo. Pela inclinação das retas obtidas, podem-se calcular os valores de ( K ).

Vesículas multilamelares (MLVs) de DPPG foram preparadas pela solubilização do lipídio numa mistura de clorofórmio/metanol $(2: 1, \mathrm{v} / \mathrm{v})$ e, posteriormente, secagem do solvente orgânico sob fluxo moderado de nitrogênio. Resíduos dos solventes foram removidos por liofilização por 1 hora. As MLVs foram obtidas pela hidratação do filme em tampão Hepes 5 mM (pH 7.4) e agitação em vórtex para homogeneização.

\section{2.9.2 Calorimetria de Titulação Isotérmica (ITC)}

A técnica de ITC também foi aplicada no estudo de interações de Pln149a e Pln149S com sistemas modelos de membrana. Nestes ensaios, a cela do calorímetro continha as 
vesículas fosfolipídicas e o peptídeo foi injetado via titulação com uma seringa. A cela do calorímetro foi preenchida com uma suspensão de LUVs de DPPG (10 mM), e Pln149a e Pln149S (solução de $100 \mu \mathrm{M}$ ) foram tituladas numa série de 5 injeções de $10 \mu \mathrm{L}$ cada.

As medidas do calor liberado/absorvido na interação de Pln149 com as vesículas fosfolipídicas foram realizadas num VP-ITC MicroCalorimeter com duas celas de 1,417 mL, sendo uma de amostra e outra de referência, a $25{ }^{\circ} \mathrm{C}$, sob agitação a $300 \mathrm{rpm}$. A cela de referencia foi preenchida com tampão Hepes, o mesmo utilizado para a preparação das LUVs e solubilização de Pln149a.

Antes do uso, as soluções foram devidamente degaseificadas por $10 \mathrm{~min}$ sob vácuo moderado (ThermoVac) para a eliminação de bolhas de ar, a $20^{\circ} \mathrm{C}$. Os calores de diluição tanto do peptídeo como dos lipossomos foram determinados em experimentos controles, em que foram injetados cada uma destas amostras no tampão. Estas curvas foram subtraídas da variação de calor determinada nos experimentos de ligação do peptídeo/vesícula correspondentes. Os dados experimentais são analisados utilizando o software ORIGIN para ITC fornecido pela MicroCal. 
RESULTADOS

E DISCUSSÕES 



\section{RESULTADOS E DISCUSSÕES}

\subsection{Síntese de peptídeos}

A fim de avançar no conhecimento estrutural e funcional das bacteriocinas conhecidas como Plantaricinas, selecionou-se o peptídeo Plantaricina 149 produzido pela cepa de Lactobacillus plantarum NRIC 149 para promover sua síntese e desenhar análogos com potencial atividade bacteriana para prosseguir com a investigação do mecanismo de ação deste AMP e correlacionar sua atividade lítica frente a sistemas modelos de membrana com a sua ação antimicrobiana observada in vitro. Pln149 é descrito na literatura como um peptídeo com espectro de ação inibidora contra alguns microrganismos, incluindo os do gênero, espécie e subespécie das LABS, tais como L. plantarum, Lactobacillus delbrueckii subsp. delbrueckii, L. delbrueckii subsp. bulgaricus, Lactobacillus helveticus, Lactobacillus casei, Leuconostoc mesenteroides, Pediococcus acidilactici, P. cerevisiae, Enterococcus hirae e Lactococcus.

Levando em conta que uma modificação pós-traducional encontrada num grande número de peptídeos antimicrobianos isolados de diferentes fontes é a amidação da extremidade C-terminal, o que está associado com a prevenção da hidrólise pelas carboxipeptidades, planejou-se a síntese de peptídeos do tipo carboxamida.

A síntese de peptídeos em fase sólida se mostrou uma técnica muito eficaz na obtenção de todos os peptídeos análogos à Plantaricina 149. Todas as etapas de acoplamento e desproteção de cada resíduo de aminoácido inserido no peptídeo foram monitoradas pelo ensaio de Kaiser, de acordo com o ensaio colorimétrico mostrado na Figura 8.

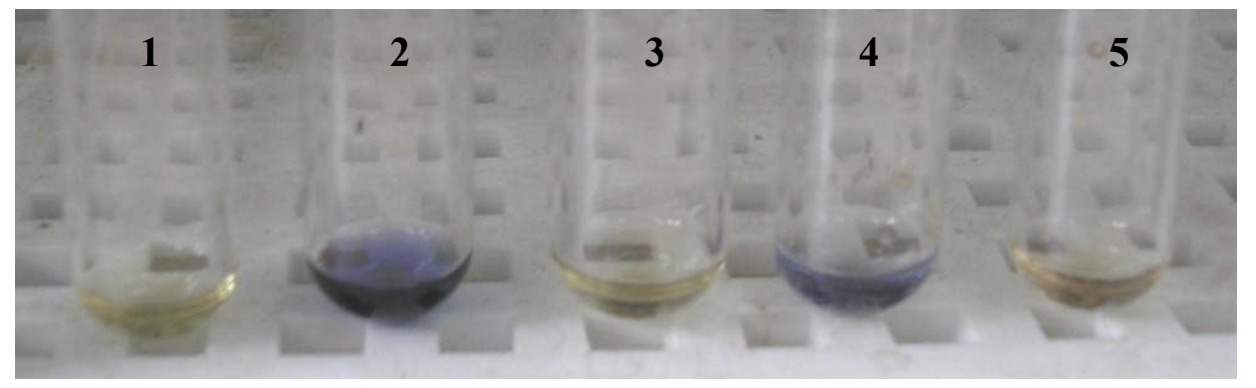

Figura 8 - Ensaio colorimétrico de Kaiser. Um acoplamento realizado com eficiência maior de $95 \%$ fornece uma solução de cor amarela e as resinas com certa transparência (tubos 1, 3 e 5). Já durante a etapa de desproteção, uma eficiência maior que $95 \%$ é evidenciada por uma solução de coloração azul e as resinas bem tingidas de azul-marinho (tubos 2 e 4 ). 
Conforme descrito, os peptídeos sintetizados foram divididos em 3 grupos com base em sua identidade seqüencial, mostrados na Tabela 4 , e as reações de síntese foram promovidas da seguinte maneira:

Síntese do Grupo I: A elongação de Pln149a e Pln149S prosseguiu com as etapas de acoplamento e desproteção de cada um dos resíduos de aminoácidos, conforme o esquema mostrado na Figura 2, até atingir a etapa de acoplamento da Ser2. Neste ponto, a resina foi divida em duas partes, cada uma delas foi colocada em uma nova seringa. Em uma delas realizou-se a desproteção ( 2 ciclos de $20 \mathrm{~min}$ ) e o acoplamento de uma Tyr em 50 min, este peptídeo corresponde à sequência da $P \ln 149$ a. Já na outra parte da resina, após a reação de desproteção do grupo Fmoc, um resíduo de Ser foi acoplado durante 50 min, e esta sequência corresponde ao peptídeo denominado Pln149S. A seqüência de acoplamento, o tempo decorrido nos ciclos de acoplamento e desproteção de cada aminoácido estão descritos na Tabela 5 (a).

A síntese dos dois outros peptídeos (Pln149W e Pln149WS), realizada posteriormente, deu-se num total de 10 dias, incluindo todas as etapas do processo: acoplamentos, desproteções, ensaios de clivagem, precipitação em éter, remoção dos capturadores, liofilização. A Tabela 5 apresenta os ciclos realizados para a incorporação de cada aminoácido aos peptídeos. O resultado satisfatório alcançado em todas as primeiras reações de acoplamento e a redução dos tempos de reação foram os grandes diferenciais desta síntese perante aquelas realizadas anteriormente. Tal resultado se deve tanto ao uso do ativador HATU, que é muito mais eficaz para promover as reações de acoplamento, quanto ao uso do excesso molar de 3 vezes de reagentes em cada ciclo, quando nas sínteses anteriores eram usados os ativadores HOBt e TBTU e um excesso molar de reagente de 2 vezes.

Síntese do Grupo II: Seguindo o esquema da Figura 2, a síntese foi realizada até atingir a etapa de acoplamento da Gly6. A partir deste ponto, a resina foi dividida em quatro partes: a primeira delas passou pela etapa de desproteção ( 2 ciclos de $20 \mathrm{~min}$ ), a segunda parte passou por uma etapa de acetilação, a terceira por uma acilação e a última parte foi submetida diretamente ao processo de clivagem. A incorporação dos grupos Acetil e N-octil foram monitoradas pelo ensaio colorimétrico de ninhidrina. A seqüência de acoplamento, o tempo decorrido nos ciclos de acoplamento e desproteção de cada aminoácido estão descritos na Tabela 5 (b). 
Síntese do Grupo III: A elongação deste peptídeo seguiu o esquema da 2 até atingir a etapa de acoplamento da Gly6. A partir deste ponto, a resina foi dividida em quatro partes: a primeira delas passou pela etapa de desproteção ( 2 ciclos de $20 \mathrm{~min}$ ), a segunda parte passou por uma etapa de acetilação, a terceira por uma acilação e a última parte foi submetida diretamente ao processo de clivagem. A incorporação dos grupos acetil e N-octil foram monitoradas pelo ensaio colorimétrico de ninhidrina. A seqüência de acoplamento, o tempo decorrido nos ciclos de acoplamento e desproteção de cada aminoácido estão descritos na Tabela 5 (c). Todos os peptídeos foram sintetizados como peptídeos do tipo carboxamida. O rendimento de síntese, as massas moleculares, a carga líquida e o ponto isoelétrico teórico de cada um destes peptídeos estão descritos na Tabela 6 . 
Tabela 5 - Roteiro de síntese dos peptídeos do Grupos I (a), II (b) e III (c)

(a)

\begin{tabular}{|c|c|c|c|c|c|}
\hline \multicolumn{6}{|c|}{ Grupo I } \\
\hline $\mathbf{a a}$ & $\begin{array}{l}\text { Acopl } \\
(\min )\end{array}$ & $\begin{array}{l}\text { Despr } \\
\text { (min) }\end{array}$ & aa & $\begin{array}{l}\text { Acopl } \\
\text { (min) }\end{array}$ & $\begin{array}{l}\text { Despr } \\
\text { (min) }\end{array}$ \\
\hline Gly & 60 & $2 \times 20$ & Gly & 15 & $2 \times 10$ \\
\hline Gly & 30 & $2 \times 20$ & Gly & 15 & $2 \times 10$ \\
\hline Lys & 65 & $2 \times 20$ & Lys & 15 & $2 \times 10$ \\
\hline Lys & 130 & $2 \times 20$ & Lys & 15 & $3 \times 10$ \\
\hline Lys & 50 & $2 \times 20$ & Lys & 15 & $3 \times 10$ \\
\hline Phe & 100 & $2 \times 20$ & $\operatorname{Trp}$ & 15 & $2 \times 10$ \\
\hline Leu & 90 & $2 \times 20$ & Leu & 15 & $2 \times 10$ \\
\hline Lys & 50 & $2 \times 20$ & Lys & 15 & $2 \times 10$ \\
\hline Lys & 50 & $2 \times 20$ & Lys & 15 & $2 \times 10$ \\
\hline Val & 50 & $2 \times 20$ & Val & 15 & $2 \times 10$ \\
\hline Gln & 50 & $2 \times 20$ & Gln & 15 & $3 \times 10$ \\
\hline Lys & 50 & $2 \times 20$ & Lys & 15 & $2 \times 10$ \\
\hline Ile & 50 & $2 \times 20$ & Ile & 15 & $2 \times 10$ \\
\hline Ala & 50 & $2 \times 20$ & Ala & 15 & $2 \times 10$ \\
\hline Thr & 50 & $2 \times 20$ & Thr & 15 & $2 \times 10$ \\
\hline Ala & 50 & $3 \times 20$ & Ala & 15 & $3 \times 10$ \\
\hline Gly & 50 & $3 \times 20$ & Gly & 15 & $2 \times 10$ \\
\hline Met & 50 & $2 \times 20$ & Met & 15 & $2 \times 10$ \\
\hline Gln & 50 & $2 \times 20$ & Gln & 15 & $2 \times 10$ \\
\hline Leu & 50 & $3 \times 20$ & Leu & 15 & $2 \times 10$ \\
\hline Ser & 50 & & Ser & 15 & $2 \times 10$ \\
\hline
\end{tabular}

(b)

\begin{tabular}{|c|c|c|c|c|c|}
\hline \multicolumn{3}{|c|}{ Grupo II } & \multicolumn{3}{|c|}{ Grupo III } \\
\hline aa & $\begin{array}{l}\text { Acopl } \\
\text { (min) }\end{array}$ & $\begin{array}{l}\text { Despr } \\
(\min )\end{array}$ & aa & $\begin{array}{l}\text { Acopl } \\
\text { (min) }\end{array}$ & $\begin{array}{r}\text { Despr } \\
(\mathrm{min})\end{array}$ \\
\hline Gly & 50 & $3 \times 20$ & Gly & 50 & $2 \times 20$ \\
\hline Gly & 30 & $2 \times 20$ & Gly & 100 & $2 \times 20$ \\
\hline Lys & 50 & $2 \times 20$ & Lys & 50 & $2 \times 20$ \\
\hline Lys & 50 & $2 \times 20$ & Lys & 50 & $2 \times 20$ \\
\hline & & & Lys & 130 & $2 \times 20$ \\
\hline Lys & 50 & $2 \times 20$ & Phe & 60 & $2 \times 20$ \\
\hline Trp & 50 & $3 \times 20$ & Leu & 60 & $2 \times 20$ \\
\hline Leu & 50 & $2 \times 20$ & Lys & 60 & $3 \times 20$ \\
\hline & & & Lys & 60 & $2 \times 20$ \\
\hline Lys & 90 & $2 \times 20$ & Val & 60 & $2 \times 20$ \\
\hline Lys & 60 & $2 \times 20$ & Gln & 60 & $2 \times 20$ \\
\hline Val & 90 & $2 \times 20$ & Lys & 100 & $3 \times 20$ \\
\hline Gln & 50 & $3 \times 20$ & Ile & 60 & $2 \times 20$ \\
\hline & & & Ala & 60 & $2 \times 20$ \\
\hline Lys & 50 & $2 \times 20$ & Thr & 60 & $2 \times 20$ \\
\hline Ile & 90 & $2 \times 20$ & Ala & 60 & $2 \times 20$ \\
\hline Ala & 50 & $2 \times 20$ & Gly & 60 & \\
\hline
\end{tabular}

(c) 
Tabela 6 - Rendimento e propriedades dos peptídeos sintetizados. O pI teórico foi calculado utilizando softwares disponíveis no ExPASy Proteomics Server. A massa molecular dos peptídeos-amida foi calculada pela soma das massas moleculares dos resíduos de aminoácidos com os grupos acoplados ao N-terminal (Fmoc, Acetil e N-octil), através do software Peptide Mass Calculator, disponível em www.peptidecalculator.net.

\begin{tabular}{llcccc}
\hline \multicolumn{1}{c}{ Peptídeo } & Rendimento(mg) & Massa(Da) & $\begin{array}{c}\text { Carga } \\
\text { (pH 7) }\end{array}$ & pI \\
\hline \multirow{2}{*}{ grupoI } & Pln149a & 170.8 & 2424.0 & +7 & 10.4 \\
& Pln149S & 96.5 & 2347.9 & +7 & 10.7 \\
& Pln149W & 180.2 & 2479.5 & +7 & 10.4 \\
& Pln149WS & 131.0 & 2403.6 & +7 & 10.7 \\
\hline \multirow{2}{*}{ grupoII } & Noctil-Pln149(6-22) & 133.8 & 1928.5 & +6 & 10.7 \\
& Ac-Pln149(6-22) & 66.1 & 1801.3 & +7 & 10.7 \\
& Fmoc-Pln149(6-22) & 167.6 & 2023.5 & +6 & 10.7 \\
\hline & Pln149W(6-22) & 76.7 & 1840.3 & +7 & 10.7 \\
& Ac-Pln149W(6-22) & 104.3 & 1882.3 & +6 & 10.7 \\
grupoIII & Noctil-Pln149W(6-22) & 83.1 & 1966.5 & +6 & 10.7 \\
& Fmoc-Pln149W(6-22) & 170.2 & 2062.5 & +6 & 10.7 \\
\hline
\end{tabular}

Muito dos AMPs caracterizados até o momento apresentam uma rede de carga positiva, variando de +2 a +9 , podendo conter domínios catiônicos altamente definidos. A cationicidade é, sem duvida, importante para a atração eletrostática dos AMPs com as membranas fosfolipídicas negativamente carregadas de bactérias e outros microrganismos. Essa eletroafinidade mútua provavelmente confere a especificidade antimicrobiana em relação ao tecido hospedeiro (84). Com base nestas considerações, é de se esperar que exista uma forte correlação entre a cationicidade do peptídeo e a atividade antimicrobiana, o que é demonstrado em muitos estudos (16,85-87). 


\subsection{Caracterização dos peptídeos}

\subsubsection{Degradação de Edman}

O seqüenciamento dos peptídeos por degradação de Edman em sistema automatizado confirmou a seqüência correta de síntese dos peptídeos após purificação em HPLC.

$\begin{array}{lr}\text { Pln149a } & \text { YSLQMGATAIKQVKKLFKKKGG } \\ \text { Pln149S } & \text { SSLQMGATAIKQVKKLFKKKGG } \\ \text { Pln149W } & \text { YSLQMGATAIKQVKKLWKKKGG } \\ \text { Pln149WS } & \text { SSLQMGATAIKQVKKLWKKKGG } \\ \text { Pln149(6-22) } & \text { GATAIKQVKKLFKKKGG } \\ \text { Pln149W(6-22) } & \text { GATAIKQVKKLWKKKGG }\end{array}$

Os demais peptídeos análogos do grupo II e grupo III são provenientes do mesmo sistema de síntese dos peptídeos Pln149(6-22) e Pln149W(6-22), respectivamente. Deste modo, apresentam a mesma estrutura primária que aquela confirmada para essas duas moléculas.

\subsubsection{Espectrometria de Massas}

As análises realizadas por espectrometria de massas confirmaram a presença dos peptídeos desejados na fração bruta de síntese, de acordo com a Figura 9. 


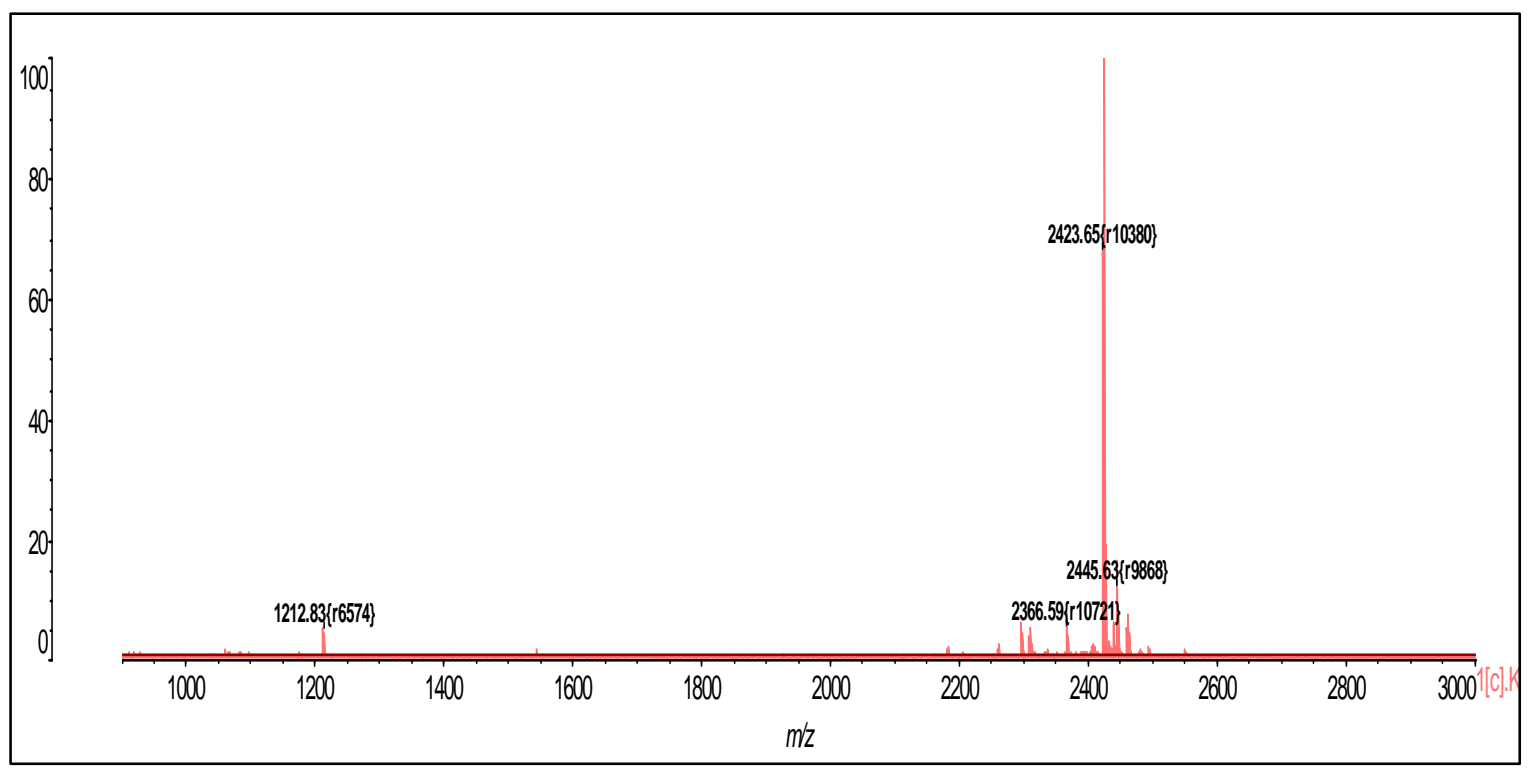

Figura 9 - Espectros de massas de PIn149a. O peptídeo Pln149a analisado por MS apresenta massa molecular por volta de 2424 Da.

Pela técnica de ionização de elétron-spray foram também determinadas as massas dos peptídeos Pln149S, Pln149W e Pln149WS, mostrados na Figura 10. Para o espectro de Pln149S, pode-se observar que o peptídeo apresenta a massa molecular de 2347 Da. Já nos outros dois espectros podem ser observados uma série de íons com razões massa/carga diferentes, estes picos correspondem a cada um dos peptídeos com diferentes protonações, apresentando cargas $+1,+2,+3$ e +4 , gerando picos em 2479.5, 1240.3, 827.3 e 620.6 Da para Pln149W e picos em 2403.6, 1202.3, 802.1 e 601.6 Da para Pln149WS. Notam-se ainda nestes espectros os picos de $\mathrm{m} / \mathrm{z}$ correspondente aos peptídeos com íons de $\mathrm{Na}^{+}$, os quais aparecem por volta de $23 \mathrm{Da}$ acima dos picos descritos acima. Após os procedimentos de desconvolução, obtiveram-se os valores de 2479 e 2403 Da para as massas moleculares de Pln149W e Pln149WS, respectivamente. 

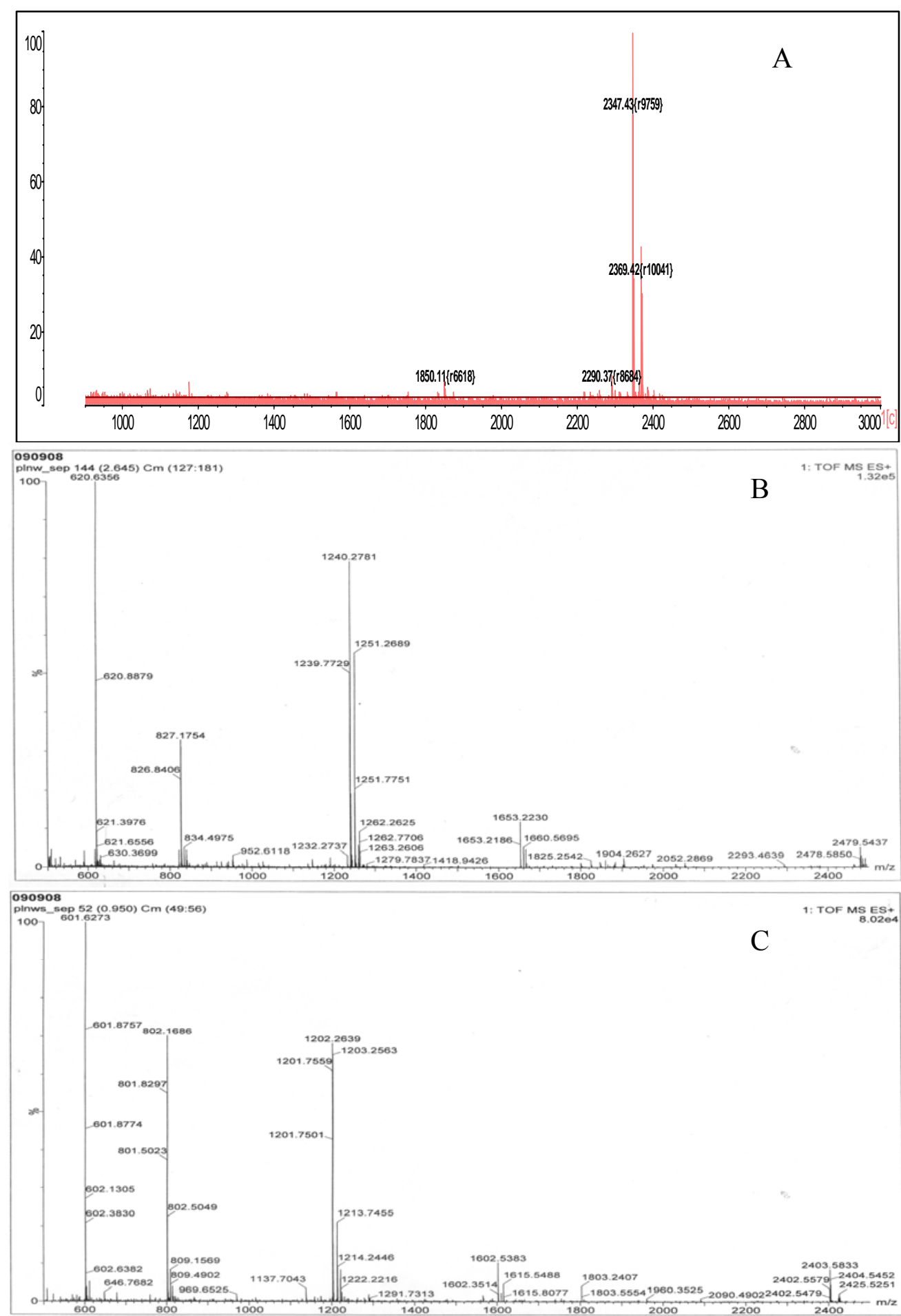

Figura 10 - Espectros de massas de Pln149S, PIn149W e PIn149WS. Os peptídeos do grupo I Pln149S (A), Pln149W (B) e Pln149WS (C) analisados por MS apresentam massas moleculares por volta de 2479 e 2403 Da.

As massas moleculares dos outros peptídeos análogos a Pln149a e sua presença na fração bruta de síntese também foram checadas por MS, de acordo com a Figura 11, que mostra os valores de 1801, 1843, 1928 e 2023 Da para Pln149(6-22), Ac-Pln149(6-22), 
Noctil-Pln149(6-22), Fmoc-Pln149(6-22), e as massas de 1840, 1883, 1967 e 2062 Da para

Pln149W(6-22), Ac-Pln149W(6-22), Noctil-Pln149W(6-22) e Fmoc-Pln149W(6-22), respectivamente.

Pln1 Plantaricina 149, dil 2ul+100ul 60\%Me0H,5\%Formic.ac. nflw 2009-ZELUIZ-SC-001 1 (1.033) M3 [Ev-129385,t110,En1] (0.250,4, Cmp)

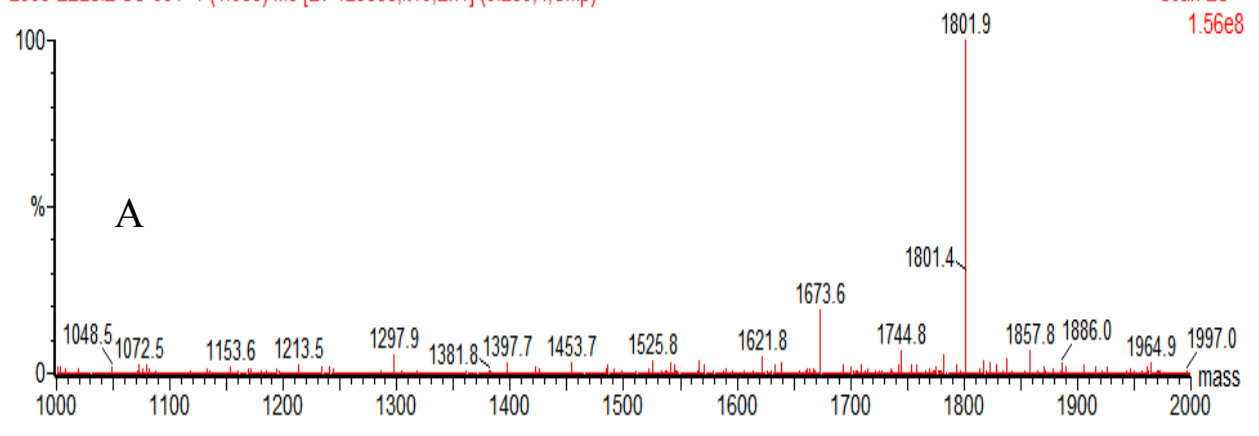

PIn2 Ac-Plantaricina, dil 2ul+100ul 60\%MeOH,5\%Formic.ac. nflw

2009-ZELUIZ-SC-007 1 (2.038) M3 [EV-138742,It10,En1] (0.250,4,Cmp)

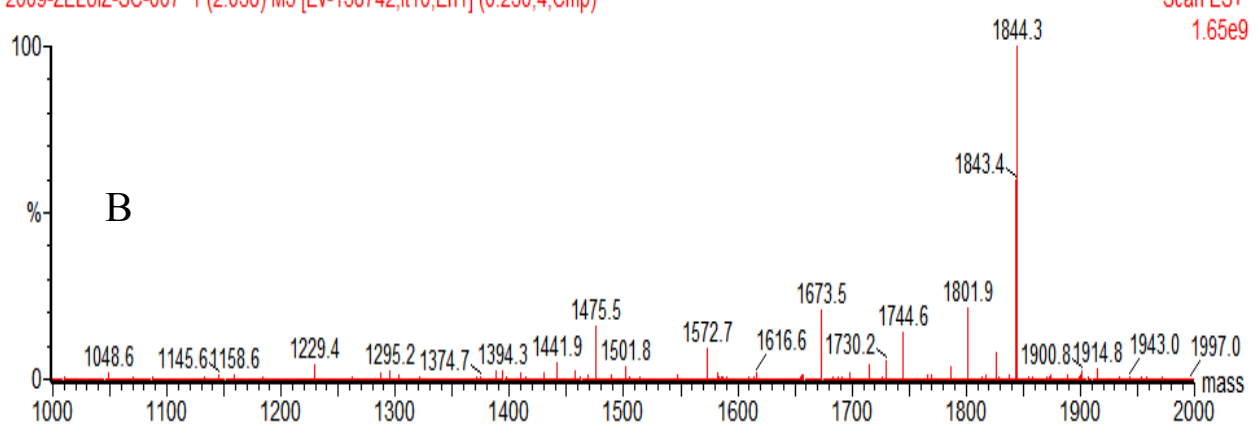

PIn3 Noctil-Plantaricina, dil 2 ul+100ul 60\% $\%$ MeOH,5\%Formic.ac. nflw-mw1912.3

2009-ZELUUZ-SC-013 1 (2.053) M3 [EV-177307,|t10,En1] (0.250,4, Cmp)

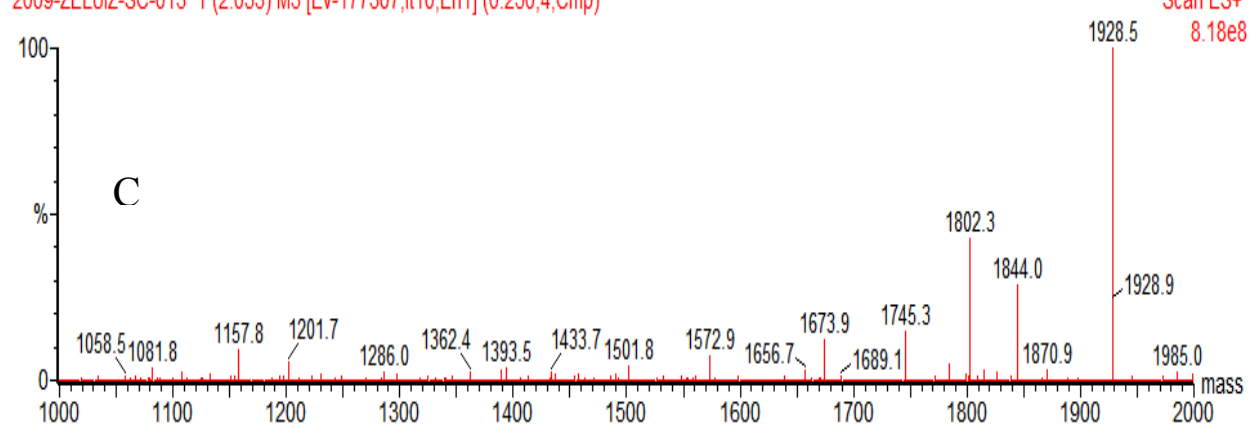

Pln4 Fmoc-plantaricina

2009-ZELUIZ-SC-023 1 (2.050) M3 [EV-175583,It10,En1] $(0.250,4$, Cmp)

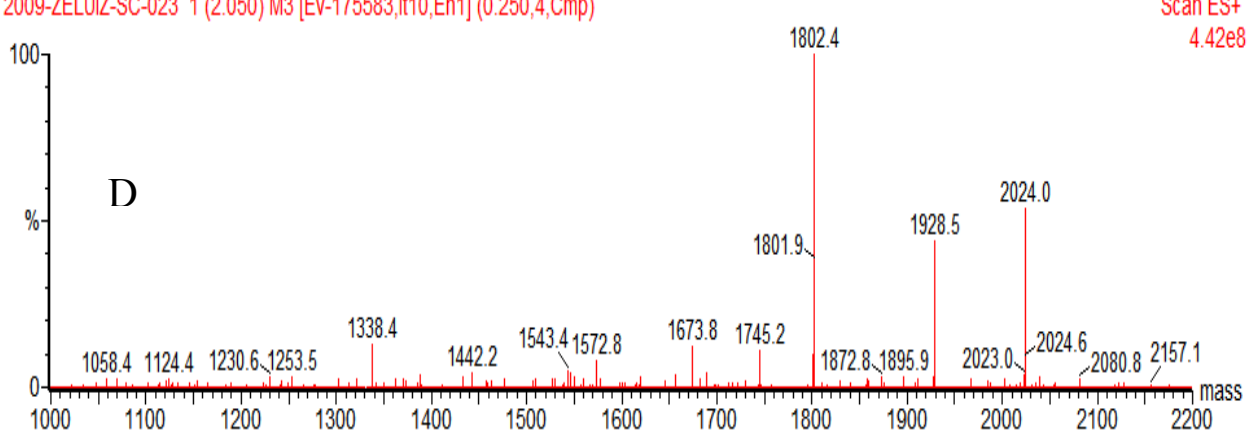

Figura 11 - Continua 

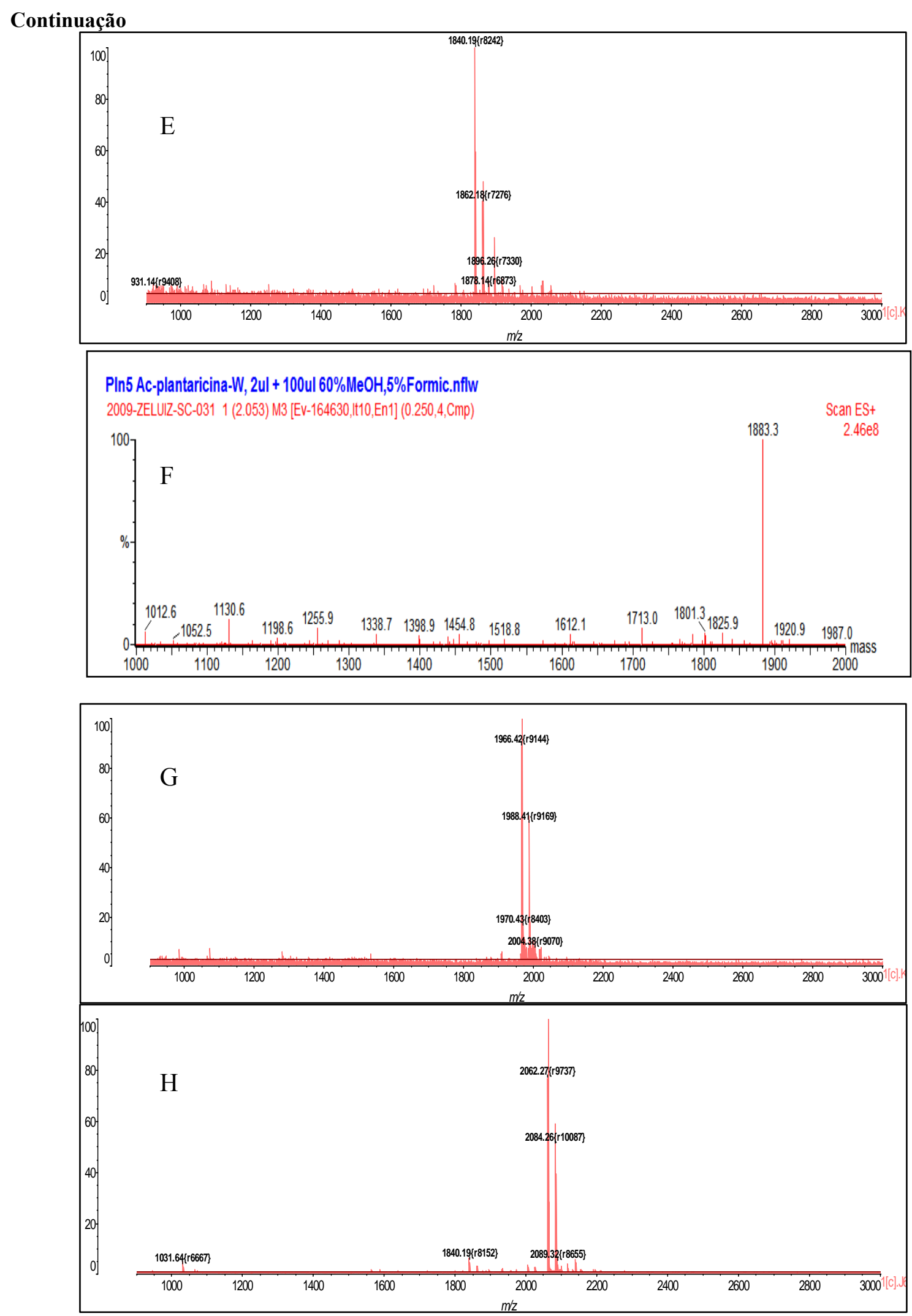

Figura 11 - Espectros de massas dos peptídeos com modificações no N-terminal. (A) Pln149(6-22), (B) Ac-Pln149(6-22), (C) Noctil-Pln149(6-22), (D) FmocPln149(6-22), (E) Pln149W(6-22), (F) Ac-Pln149W(6-22), (G) NoctilPln149W(6-22) e (H) Fmoc-Pln149W(6-22) Os peptídeos foram analisados por ES-TOF-MS . 


\subsection{Purificação dos peptídeos}

Uma vez confirmada a presença dos peptídeos de interesse na fração bruta de síntese, partiu-se para a purificação das frações de interesse. O perfil cromatográfico da eluição dos peptídeos em coluna $\mathrm{C}_{18}$ revelou um grau de pureza satisfatório e também a eficiência da síntese, devido à presença majoritária de um pico de absorção correspondente às frações de interesse no peptídeo bruto e um bom grau de pureza destas frações. A Figura 12 mostra os cromatogramas da purificação destes peptídeos. As frações contendo os picos de interesse foram coletadas, diluídas em água e deixadas secar overnight em sistema SpeedVac ou em liofilizadora, para utilização nos estudos posteriores.
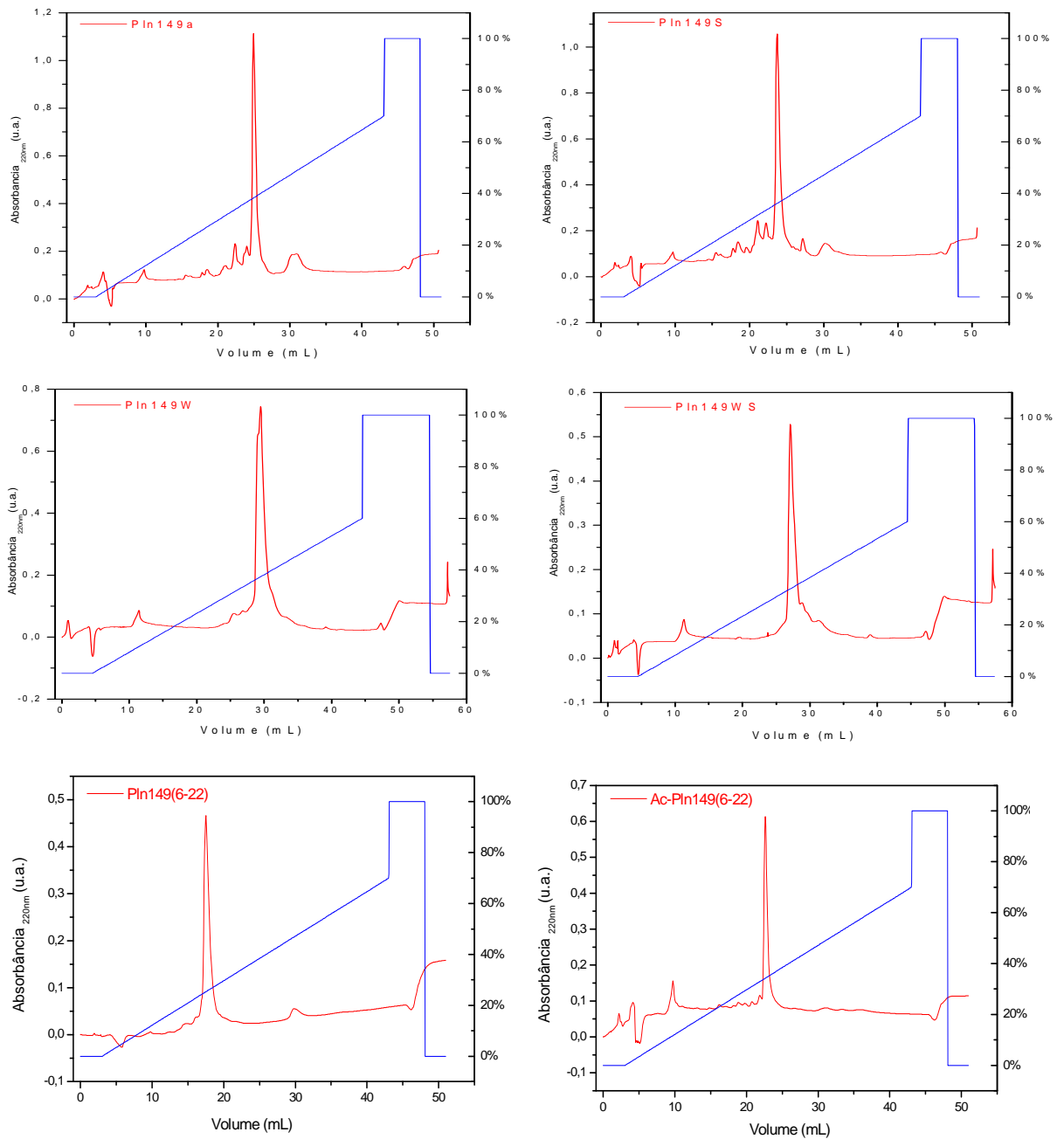

Figura 12 - Continua 


\section{Continuação}
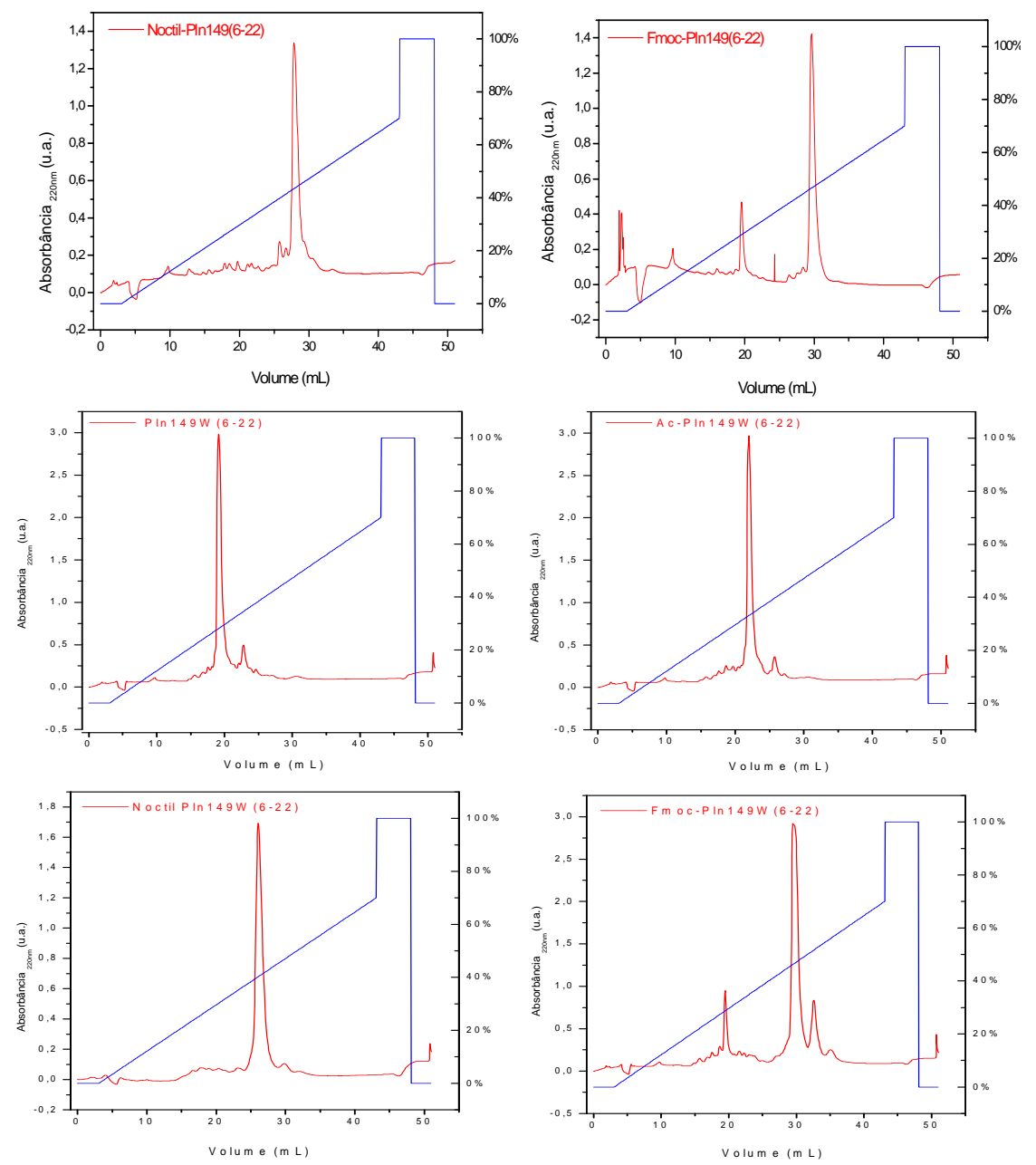

Figura 12 - Perfil cromatográfico da eluição dos peptídeos em coluna $\mathbf{C}_{\mathbf{1 8}}$. Os peptídeos do grupo I (Pln149a, Pln149S, Pln149W e Pln149WS), do grupo II (Pln149(6-22), Ac-Pln149(6-22), Noctil-Pln149(6-22) e Fmoc-Pln149(6-22)) e do grupo III (Pln146W(6-22), Ac-Pln149W(6-22), Noctil-Pln149W(6-22) e Fmoc-Pln149W(6-22) foram eluídos num gradiente linear de 0 a 70\% de solvente B (TFA 0,1\%, acetonitrila $90 \%$ em $\mathrm{H}_{2} \mathrm{O}$ ) durante 40 minutos, sob um fluxo de $1 \mathrm{~mL} / \mathrm{min}$.

A pequena diferença de hidrofobicidade, por exemplo, entre os peptídeos Pln149a e Pln149S, (de 38 e 36\%, respectivamente), e entre Pln149W e Pln149WS, (de 46 e 42\%, respectivamente) se deve a substituição do resíduo de Tyr do N-teminal de Pln149a e Pln149W para um resíduo de Ser em Pln149S e Pln149WS uma vez que todos os outros resíduos são iguais. Logo, observando a cadeia lateral destes dois aminoácidos, podemos notar que Pln149a e Pln149W são os mais hidrofóbicos por apresentar um grupo aromático (fenil) em sua cadeia lateral que não está presente em Ser, conforme visto na Figura 13. Esta diferença foi comprovada pelo maior tempo de retenção dos análogos contendo a Y (Pln149a e $\mathrm{Pln} 149 \mathrm{~W})$. 
Ser<smiles>NC(C=O)Cc1ccc(O)cc1</smiles>

Figura 13 - Estrutura química dos aminoácidos Serina e Tirosina. A cadeia lateral do resíduo de Tyr apresenta um grupo fenil aromático que confere maior hidrofobicidade a este resíduo.

O aumento da hidrofobicidade dos peptídeos modificados com a adição dos grupos acetil, N-octil e Fmoc em seus N-terminais foi notado devido ao atraso ocasionado no tempo de retenção destas moléculas quando comparadas com os peptídeos com o N-terminal livre. Por exemplo, o peptídeo Pln149(6-22)W foi eluído por volta de 19 minutos, já o peptídeo AcPln149W(6-22), foi eluído em 22 minutos, o Noctil-Pln149W(6-22), em 26 min e o FmocPln149W(6-22), em 30 minutos. O tempo de retenção dos peptídeos Pln149W(6-22), AcPln149W(6-22), Noctil-Pln149W(6-22) e Fmoc-Pln149W(6-22) correspondem a uma hidrofobicidade de 28, 33, 40 e 47\% deste gradiente de Acetonitrila, respectivamente. A Tabela 7 mostra o tempo de retenção e a hidrofobicidade correspondente de cada peptídeo sintetizado.

Tabela 7 - Tempo de eluição e hidrofobicidade dos peptídeos sintetizados. A hidrofobicidade está com base no gradiente de acetonitrila utilizado para a eluição dos peptídeos.

\begin{tabular}{|c|c|c|c|}
\hline & Peptídeo & Tempo eluição (min) & Hidrofobicidade(\%) \\
\hline \multirow{4}{*}{ grupoI } & $\mathrm{Pln} 149 \mathrm{a}$ & 25 & 38 \\
\hline & $\mathrm{Pln} 149 \mathrm{~S}$ & 24 & 36 \\
\hline & Pln149W & 29 & 46 \\
\hline & Pln149WS & 27 & 42 \\
\hline \multirow{4}{*}{ grupoII } & $P \ln 149(6-22)$ & 17 & 25 \\
\hline & $A c-P \ln 149(6-22)$ & 22 & 34 \\
\hline & Noctil-Pln149(6-22) & 27 & 43 \\
\hline & Fmoc-Pln149(6-22) & 29 & 46 \\
\hline \multirow{4}{*}{ grupoIII } & Pln149W(6-22) & 19 & 28 \\
\hline & Ac-Pln149W(6-22) & 22 & 33 \\
\hline & Noctil-Pln149W(6-22) & 26 & 40 \\
\hline & Fmoc-Pln149W(6-22) & 30 & 47 \\
\hline
\end{tabular}




\subsection{Ensaios de Atividade Biológica}

\subsubsection{Atividade Hemolítica}

Neste ensaio, a hemólise foi detectada visualmente no controle positivo logo após a adição da solução de TritonX-100 a 1 \% (v/v), devido a formação de uma solução vermelha, enquanto no controle negativo (PBS), observou-se apenas a sedimentação das células. Deste modo, avaliando a atividade hemolítica de cada um dos peptídeos sintetizados, a sedimentação das hemácias também foi observada na grande maioria dos poços correspondentes ao intervalo de 1 a $500 \mu \mathrm{M}$ de cada peptídeo.

A medida da absorbância para monitorar a lise das células mostrou que os peptídeos do grupo I (Pln149a, Pln149S Pln149W e Pln149WS) não apresentaram efeito hemolítico significativo (valores de hemólise menores que 5\%), conforme mostrado na Figura 14A. Um efeito semelhante também foi observado para os análogos do grupo II, onde não foi observada atividade hemolítica significativa, com exceção apenas do análogo-Fmoc, o qual apresentou atividade hemolítica fraca em concentrações inferiores a $125 \mu \mathrm{M}$ (de até 7\%), mas nos poços referente às concentrações de 250 e $500 \mu \mathrm{M}$, uma solução avermelhada foi observada, representando um efeito hemolítico de 12 e $24.4 \%$, respectivamente.

Os análogos do grupo III que apresentaram baixa lise celular foram Pln149W(6-22) e Ac-Pln149W(6-22). Mas uma atividade hemolítica mais relevante foi observada para os outros 2 análogos. O análogo-Noctilado não promoveu a lise das hemácias até a concentração de $62 \mu \mathrm{M}$ (valores inferiores a 4\%), mas valores de 12, 24 e $32 \%$ foram notados para as concentrações de 125, 250 e $500 \mu \mathrm{M}$, respectivamente. Já o análogo-Fmoc lisou 29\% das hemácias já em $62 \mu \mathrm{M}$, e foi aumentando a fração de lise à medida que concentração do peptídeo aumentava, atingindo $67 \%$ de hemólise para o poço de $500 \mu \mathrm{M}$ do peptídeo.

A baixa capacidade de Pln149a e análogos do grupo I em provocar a lise nas membranas dos eritrócitos humanos está associada à falta de especificidade/ligação destes peptídeos em vesículas constituídas majoritariamente de fosfolipídios zwitteriônicos. Tal fato evidencia a seletividade destes peptídeos para as células de microrganismos, uma característica de elevada importância nos AMPs. O mesmo pode ser dito dos demais análogos com modificações no Nterminal, onde apesar do aumento do caráter apolar dos peptídeos análogos sintetizados, visto 
durante a eluição no gradiente de $\mathrm{ACN}$, três destes peptídeos com permaneceram com baixo nível de atividade de hemolítica.
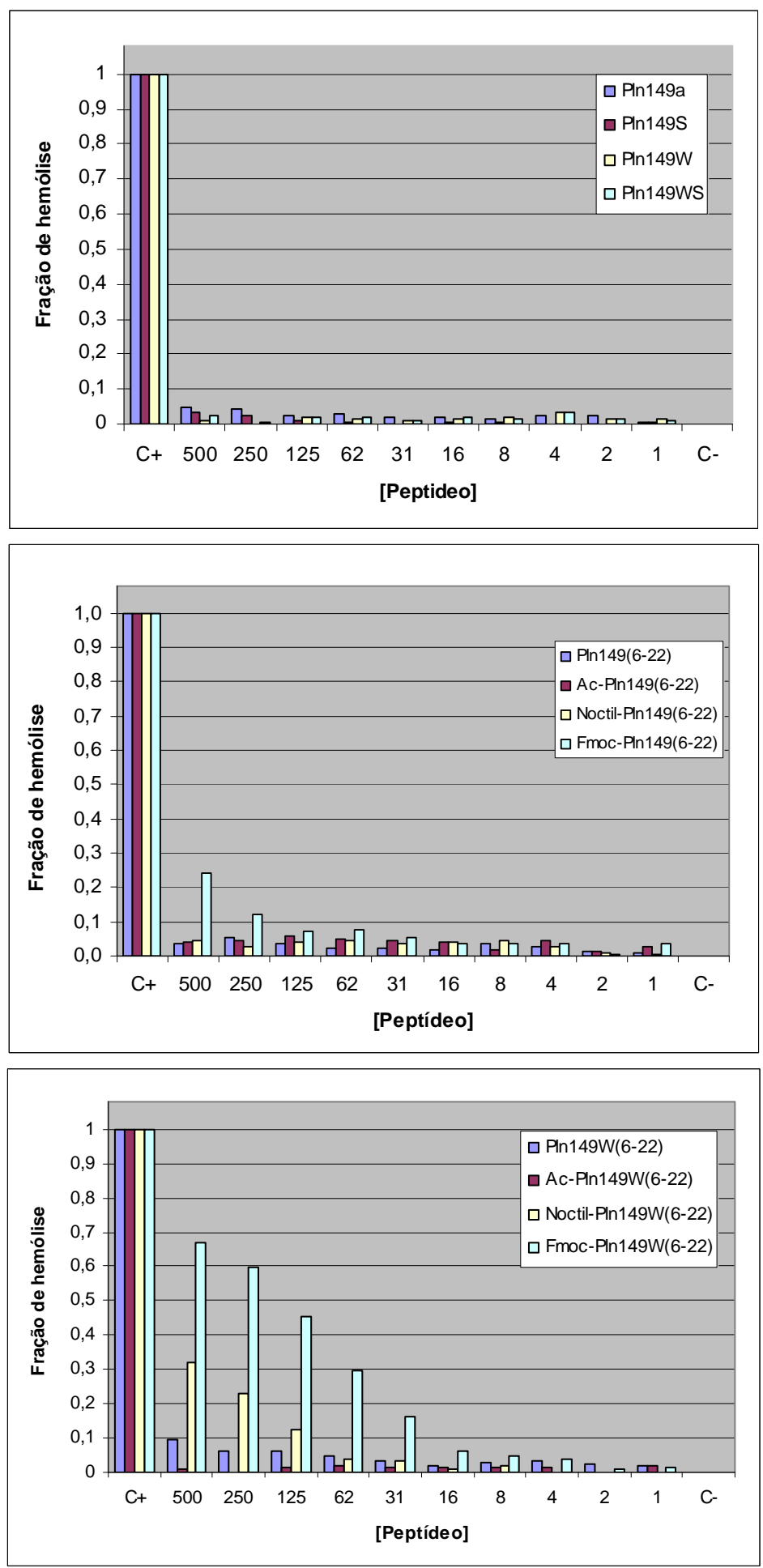

Figura 14 - Atividade hemolítica de PIn149a e peptídeos análogos. Ensaio de lise celular de células vermelhas humanas. 100\% hemólise corresponde ao valor obtido com Triton X-100. 


\subsubsection{Inibição do crescimento de microrganismos}

\subsubsection{Ensaio Antibiograma}

Os ensaios de inibição do crescimento de microrganismos realizado em placas de Petri com meio de cultura sólido realizados tanto para Pln149a e Pln149S (identificados por Y e S nas placas, respectivamente) não apresentaram formação de halo de inibição para nenhuma das cepas testadas, mostrado na Figura 15.

Um dos primeiros fatores que pode impedir a inibição de microrganismos neste ensaio é a molécula ficar retida no disco colocado sobre o meio de cultura, que pode ocorrer tanto por de interações com grupos polissacarídicos ou pela alta absorção do disco, impedindo a entrega da solução protéica molécula ao ágar. Já sabemos que Pln149 não mostrou interação com grupos polissacarídicos, então para sanar a dúvida da segunda hipótese, utilizamos outro composto protéico, denominado Aplisia (em estudo na UFC), que já é sabido apresentar atividade antimicrobiana sobre algumas cepas (Staphylococcus aureus, por exemplo) como um controle para observar se havia a liberação da solução depositada no disco para o meio de cultura. Desta forma, outro disco foi colocado nas placas de S. aureus, e sobre ele foi depositada uma solução do composto antimicrobiano $(5 \mu \mathrm{L})$, que foi incubado juntamente com o ensaio com os peptídeos. Após o tempo de incubação, pôde-se constatar a liberação da molécula protéica do disco para o meio (Figura 15F), eliminando, assim, este fator do motivo que impediu a inibição dos peptídeos às cepas.

Outro motivo a ser levado em conta, é que alguns peptídeos antimicrobianos apresentam problemas de difusão em meio sólido (ágar) ou interagem fortemente com componentes do meio de cultura, o que faz com que sua atividade seja reduzida nestes ensaios, a concentração inibitória determinada está em quantidades muito maiores do que seriam em outros meio. Uma atividade antimicrobiana dependente do meio de cultura para peptídeos já está descrita na literatura $(88,89)$. 


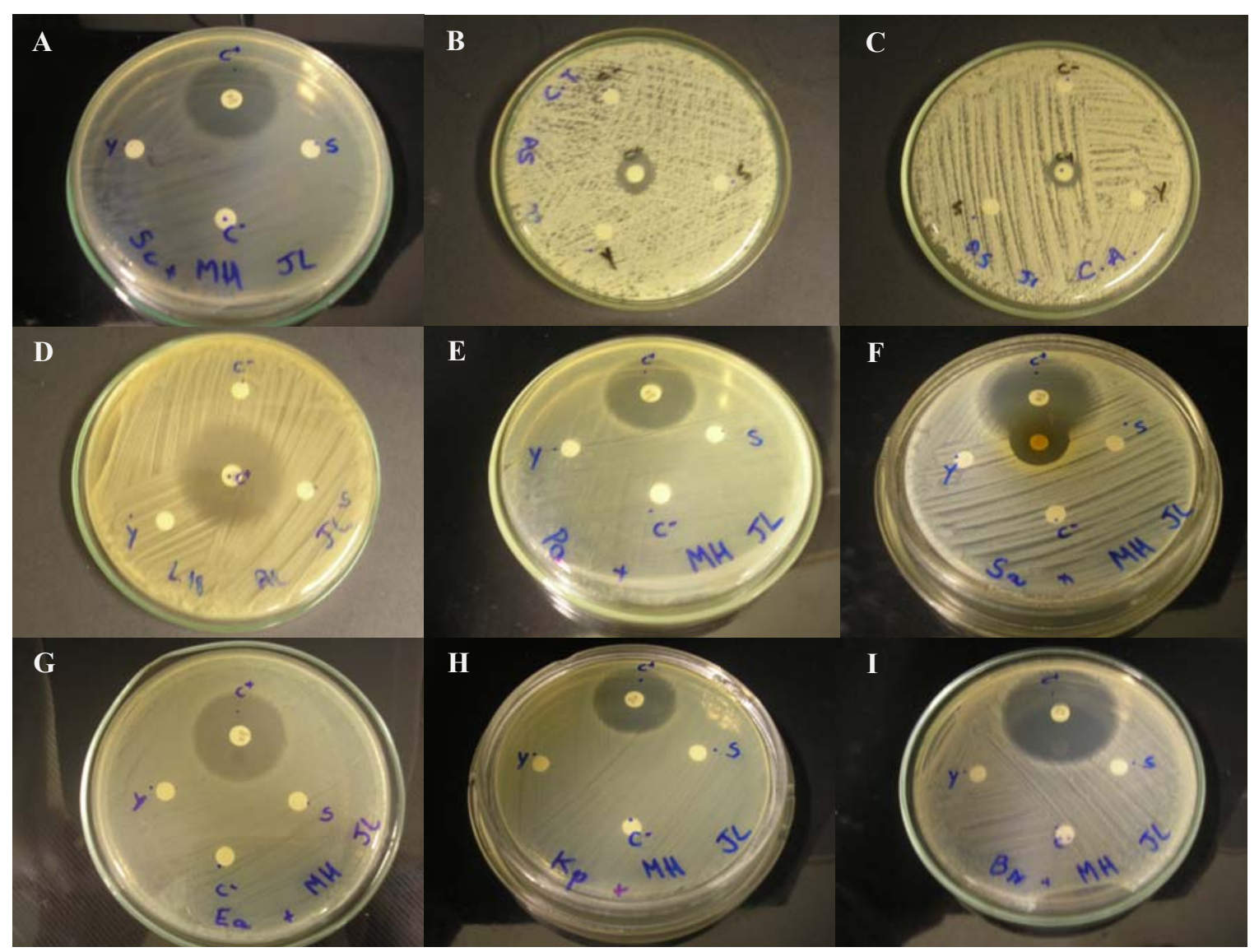

Figura 15 - Ensaio antibiograma realizado com Pln149a (identificado nas placas por Y) e PIn149S (identificado como S) sobre diferentes microrganismos. (A) Salmonella choleraesius, (B) Candida tropicalis, (C) Candida albicans, (D) Lactobacillus sp L18, (E) Pseudomonas aeruginosa, (F) Staphylococcus aureus, (G) Enterobacter aerogenes, (H) Klebisiella pneumonia e (I) Bacillus subtilis.

\subsubsection{Determinação da MIC}

Ensaios de inibição do crescimento de microrganismos em meio de cultura líquido foram realizados a fim de melhor caracterizar a ação de Pln149a e Pln149S. Na Figura 16 estão as curvas de crescimento de S.aureus monitoradas pela leitura da absorbância em espectrofotômetro, que mostra que não houve crescimento deste microrganismo quando incubado com Pln149a numa concentração de $78 \mu \mathrm{M}$ ou mais elevadas. As curvas de concentrações de 38 e $19 \mu \mathrm{M}$ mostram um aumento gradativo da quantidade de células/poço, porém possuem uma inibição do crescimento por volta de 78 e $61 \%$, respectivamente. A $\mathrm{MIC}_{50}$ foi calculada como $19 \mu \mathrm{M}(46 \mu \mathrm{g} / \mathrm{mL})$. 
Para Pln149S, a inibição do crescimento deu-se para concentrações a partir de $19 \mu \mathrm{M}$, com uma inibição do crescimento da ordem de $98 \%$. No entanto, a diluição seguinte (por volta de $10 \mu \mathrm{M})$ já apresenta um crescimento semelhante ao controle, com inibição de apenas 9\% do crescimento de S.aureus. Portanto, a $\mathrm{MIC}_{50 \%}$ de Pln149S para estes microrganismos também foi determinada como $19 \mu \mathrm{M}(44 \mu \mathrm{g} / \mathrm{mL})$.
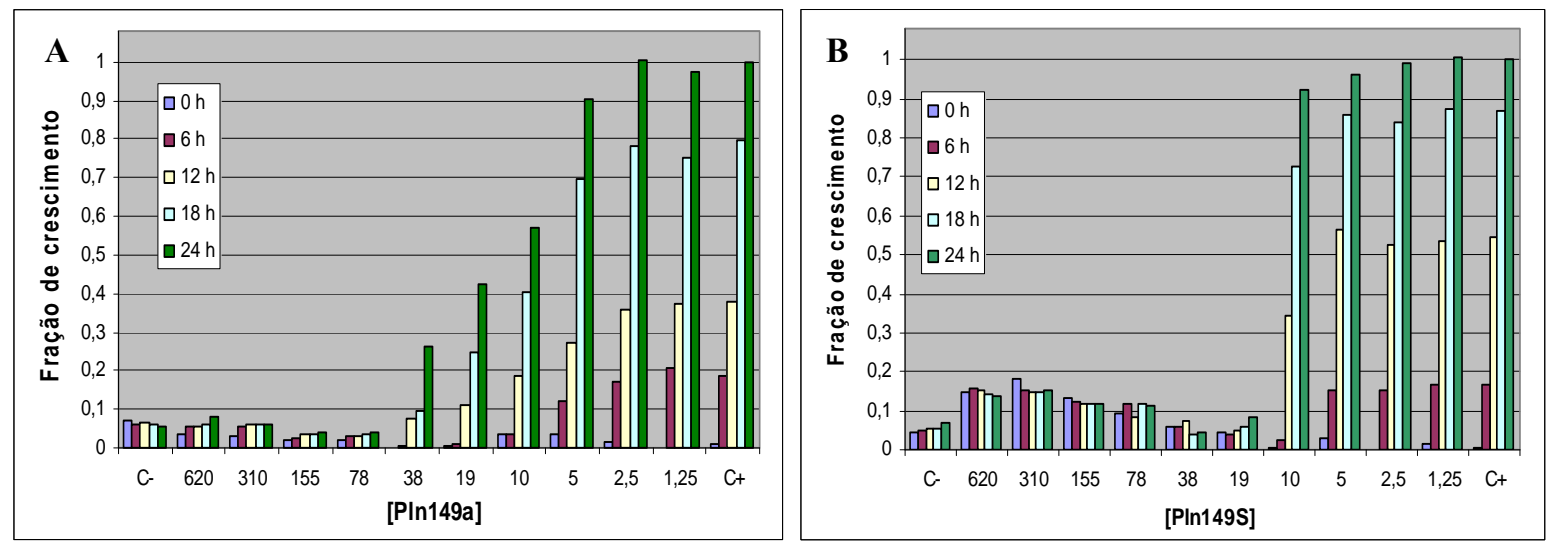

Figura 16 - Curvas de crescimento de S. aureus. A bactéria foi crescida na presença de diferentes concentrações dos peptídeos (A) Pln149a e (B) Pln149S.

O ensaio de inibição realizado com P.aeruginosa está mostrado na Figura 17. Observando as curvas de crescimento da bactéria, vemos que apenas as concentrações mais altas de ambos os peptídeos $(620$ e $310 \mu \mathrm{M})$ foram capazes de impedir o crescimento da bactéria. Já a partir de $78 \mu \mathrm{M}$, observou-se uma inibição do crescimento inferior a $15 \%$ para Pln149a, e de 8\% para Pln149S. Assim, o valor da $\mathrm{MIC}_{50}$ para Pln149a e Pln149S é de 155 $\mu \mathrm{M}(369$ e $363 \mu \mathrm{g} / \mathrm{mL})$, com inibições de 50 e $62 \%$, respectivamente.
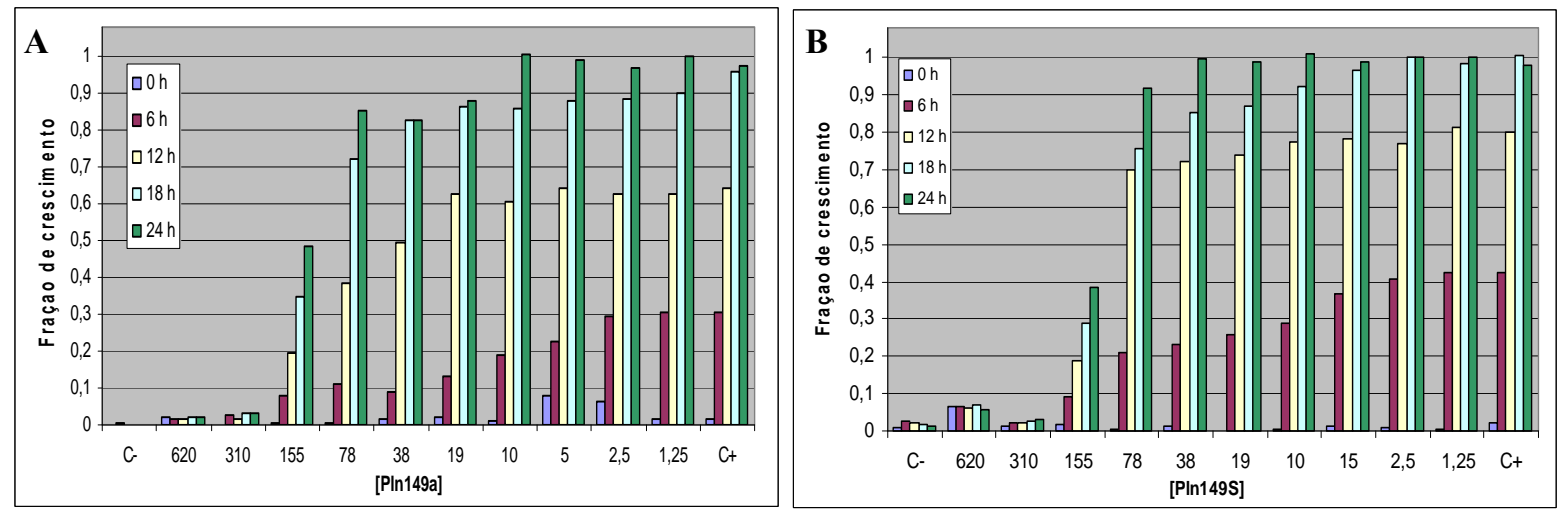

Figura 17 - Curvas de crescimento de $P$. aeruginosa. Ensaio realizado na presença de diferentes concentrações dos peptídeos Pln149a (A) e Pln149S (B). 
Pln149a mostrou atividade antimicrobiana mais forte contra Staphylococcus aureus, o que se explica pelo fato desta bactéria patogênica apresentar cerca de $60 \%$ de fosfolipídios do tipo PG em sua membrana celular (90), para o qual foi mostrado que o peptídeo apresenta alta afinidade. Nenhum crescimento bacteriano foi observado na presença do Pln149a no intervalo de 78 para 620 M. A ação mais eficaz contra bactérias Gram-positivas é uma característica compartilhado de muitos AMPs isolados de anfíbios $(91,92)$ que inibem o crescimento de Staphylococcus, Listeria. Além disso, os valores da MIC determinado para Pln149a concordam com o observado para a atividade antimicrobiana de magaininas contra bactérias, fungos e protozoários, que apresenta MICs por volta de 10-100 $\mu \mathrm{g} / \mathrm{mL}$ (16).

Após o término do ensaio, alíquotas de cada um dos poços foram subcultivadas em placas de Petri contendo o meio de cultura $\mathrm{MH}$ a fim de notar se os poços cuja inibição do crescimento foi observado continha células viáveis a se multiplicarem quando colocadas em meio de cultura na ausência do peptídeo, ou seja, a fim de notar se o peptídeo apresentava ação bactericida ou bacteriostática (Figura 18).

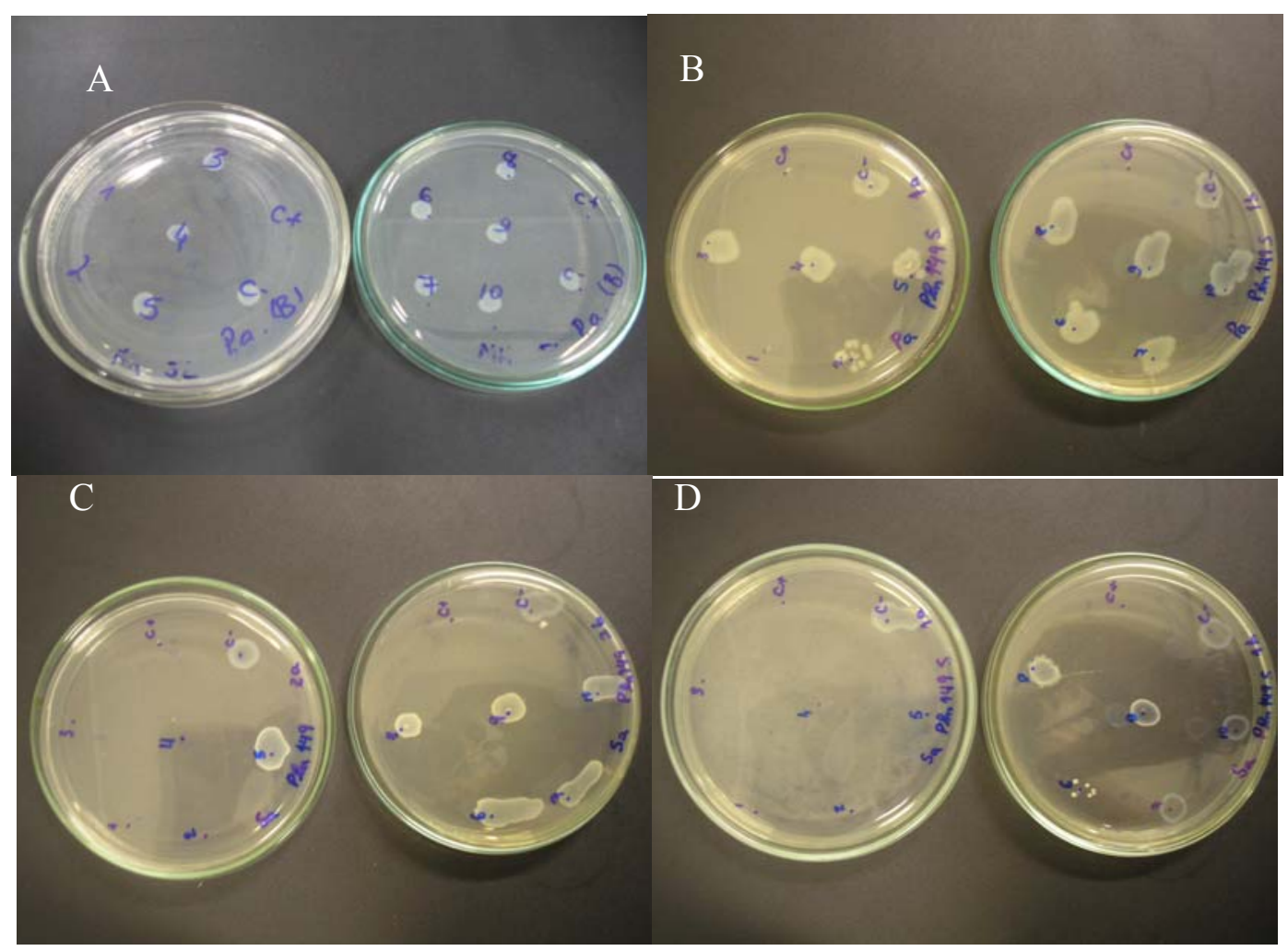

Figura 18 - Subcultivo dos poços do ensaio de MIC. Ensaio realizado para Pln149a contra P.aeruginosa (A) e S.aureus (C), e também de Pln149S para essas duas bactérias (B e D), respectivamente. 
Pln149a e Pln149S foram provados ter atividade letal para estes dois microrganismos. No entanto, Pln149a atuando de modo bactericida nas duas primeiras diluições do ensaio com P.aeruginosa, no qual o crescimento da bactéria no poço de diluição (1:4), correspondente à concentração de $155 \mu \mathrm{M}$ está de acordo com as curvas de crescimento da Figura 17. Já para Pln149S, vê-se pela Figura 18B a inibição do crescimento deste microrganismo ocorreu de modo bactericida somente na diluição (1:1), com o crescimento das células já em concentrações a partir de $310 \mu \mathrm{M}$. Para os poços com diluições maiores, tanto para Pln149a, como para Pln149S, notou-se o crescimento do microrganismo sobre a placa de Petri.

No ensaio com S.aureus, a ação bactericida dos dois peptídeos atingiu valores mais baixos da concentração dos peptídeos. Na Figura 18C, notamos o efeito bactericida de Pln149a até uma concentração de $78 \mu \mathrm{M}$ (diluição 1:8), e o de Pln149S, até a concentração de $38 \mu \mathrm{M}$ (diluição 1:16).

Esta diferença nos valores de concentração em que a ação bactericida dos peptídeos foi observada para P.aeruginosa e S.aureus está associada com a diferença na composição lipídica das membranas biológicas destas bactérias, uma vez que uma delas é do tipo Gram (-) e outra do tipo Gram (+), e como já descrito, o efeito lítico causado pelos peptídeos é dependente da composição lipídica da célula-alvo.

O ensaio de inibição do crescimento com Candida albicans para Pln149a e Pln149S, mostrado na Figura 19, revela que não houve alteração do crescimento desta levedura devido a ação destes AMPs. Tal resultado é justificado do mesmo modo da ocorrência da baixa lise celular nas membranas de eritrócitos, pois a membrana celular deste organismo também apresenta presença majoritária de fosfolipídios zwiteriônicos (por volta de 89\%, sendo 70\% da série PE) (90), e Pln149a e análogos não devem se ligam a estes fosfolipídios. 

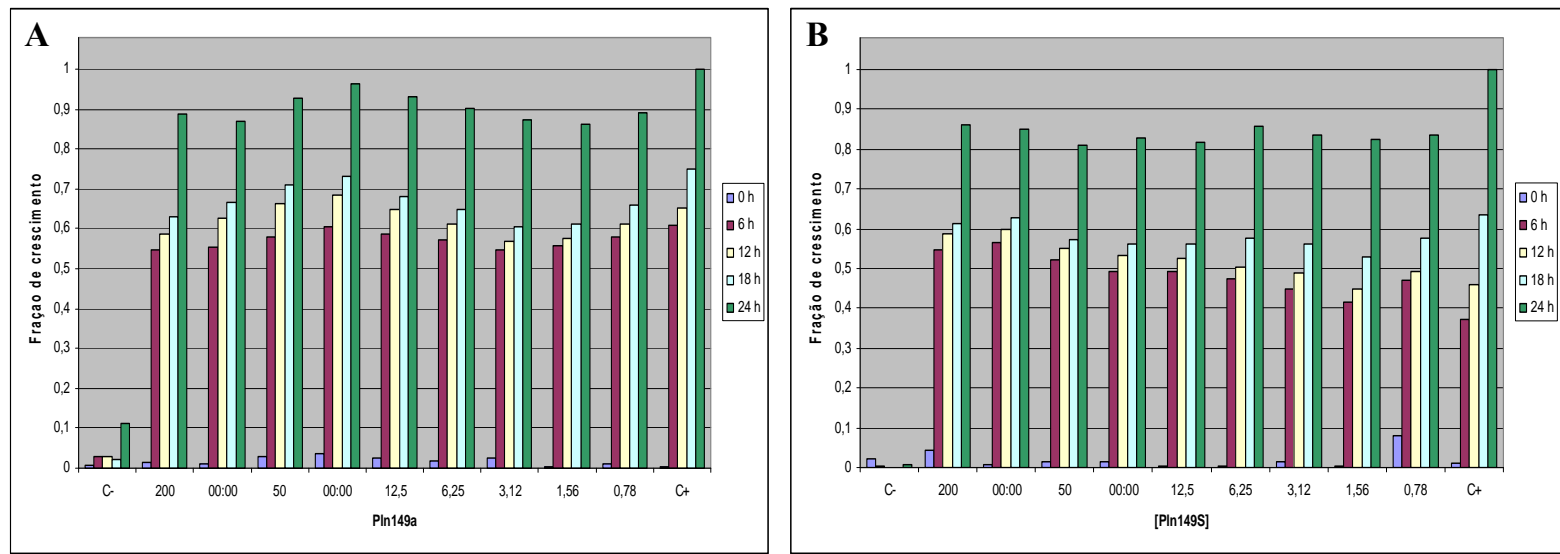

Figura 19 - Curvas de crescimento de C.albicans. Ensaio realizado na presença de diferentes concentrações dos peptídeos. (A) Pln149a e (B) Pln149S incubados com o microrganismo por $24 \mathrm{~h}$.

Do mesmo modo, o ensaio de inibição de Lactobacillus L18 para ambos Pln149a e Pln149S, mostrados na Figura 20, revelam o baixo efeito tóxico destes peptídeos para frente a estas células, pois um crescimento acima de $50 \%$ da bactéria foi observado para a concentração de $200 \mu \mathrm{M}$ do AMP, após 24 h de incubação. Para concentrações inferiores (diluições seguintes), um crescimento normal da bactéria foi observado.
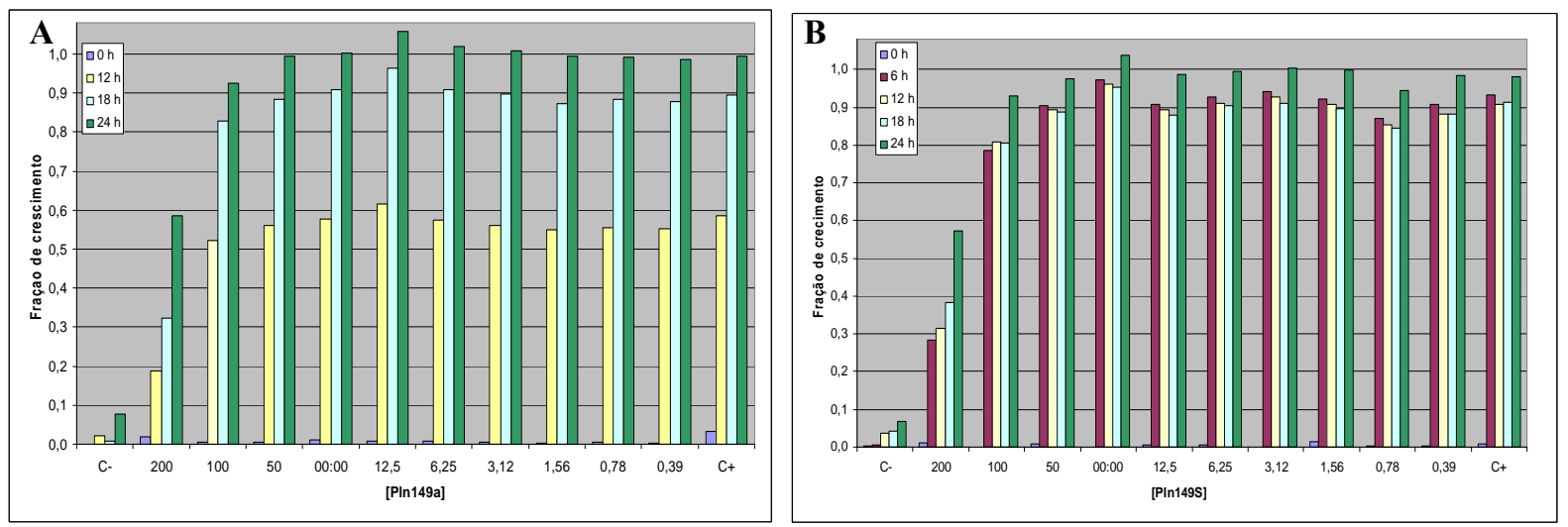

Figura 20 - Curvas de crescimento de Lactobacillus L18. Ensaio realizado na presença de diferentes concentrações dos peptídeos. (A) Pln149a e (B) Pln149S apresentam baixo efeito inibitório para o crescimento destas células.

O resultado do ensaio de inibição de Staphylococcus aureus ATCC 25923 e Pseudomonas aeruginosa ATCC 9027 pela ação dos outros peptídeos análogos a Pln149a também foi realizado, e os resultados estão descritos a seguir. É interessante observar que, mesmo com a redução do tamanho do peptídeo Pln149, os quatro análogos ainda preservaram a sua propriedade inibitória contra essas duas cepas bacterianas. No entanto apresentaram valores mais elevados para as MICs. 
$\mathrm{Na}$ Figura 21, estão mostrados os ensaio para a determinação das $\mathrm{As} \mathrm{MIC}_{50}$ de Pln149(6-22), Ac-Pln149(6-22), Noctil-Pln149(6-22) e Fmoc-Pln149(6-22) contra S. aureus, que foram de $78 \mu \mathrm{M}, 78 \mu \mathrm{M}, 10 \mu \mathrm{M}$ e $38 \mu \mathrm{M}$, respectivamente.
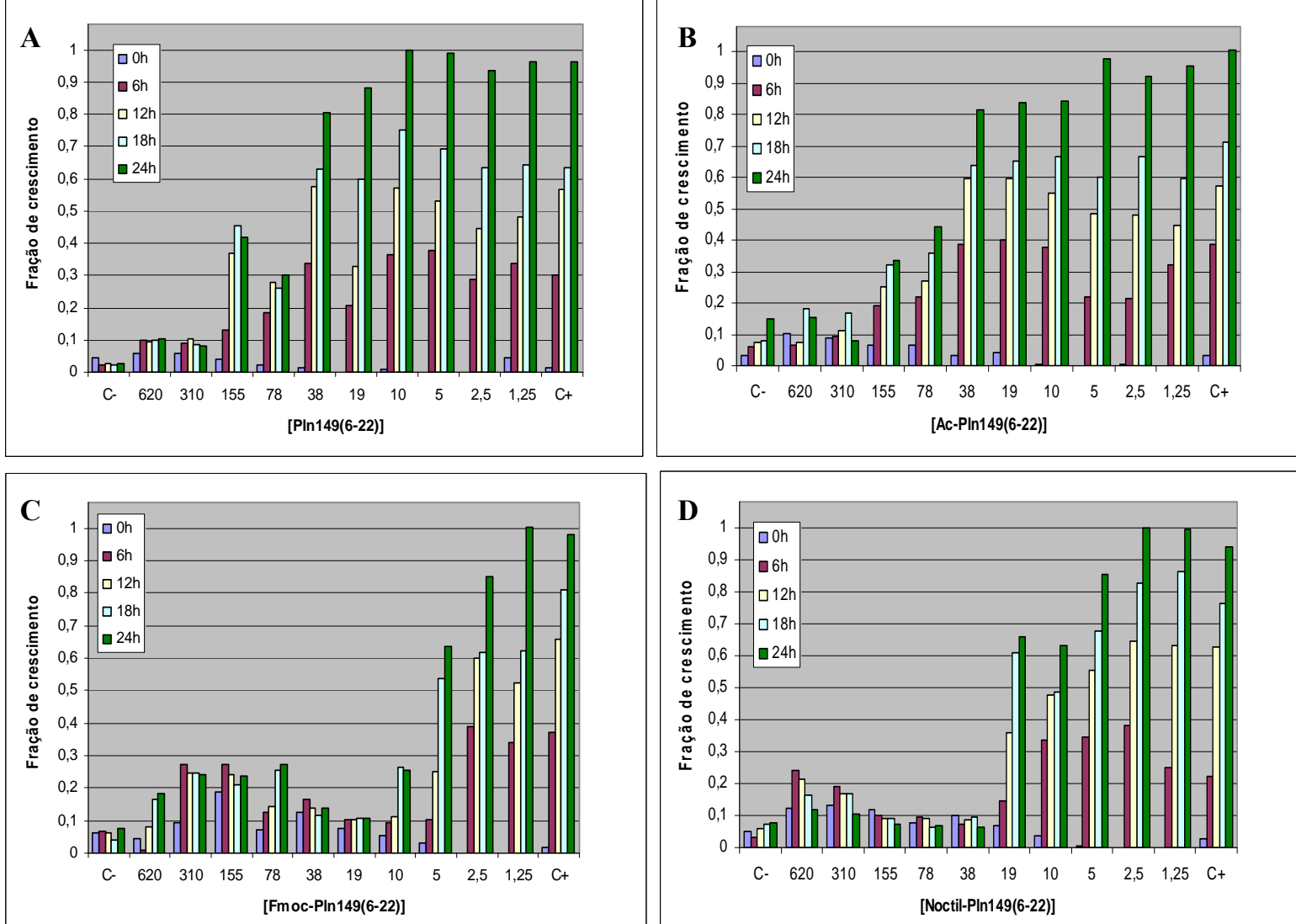

Figura 21 - Curvas de crescimento de $S$. aureus. Ensaio realizado na presença de diferentes concentrações dos peptídeos análogos do grupo II. (A) Pln149(6-22), (B) Ac- Pln149(6-22), (C) Noctil- Pln149(6-22) e (D) Fmoc-Pln149(6-22).

Na Figura 22 estão as curvas de inibição do crescimento de Pseudomonas aeruginosa para os análogos do grupo II. Neste ensaio, as $\mathrm{MIC}_{50}$ de $\mathrm{Pln} 149$ (6-22), Ac-Pln149(6-22), Noctil-Pln149(6-22) e Fmoc-Pln149(6-22) foram determinadas de 155, 155, 155 e $19 \mu \mathrm{M}$, respectivamente. 

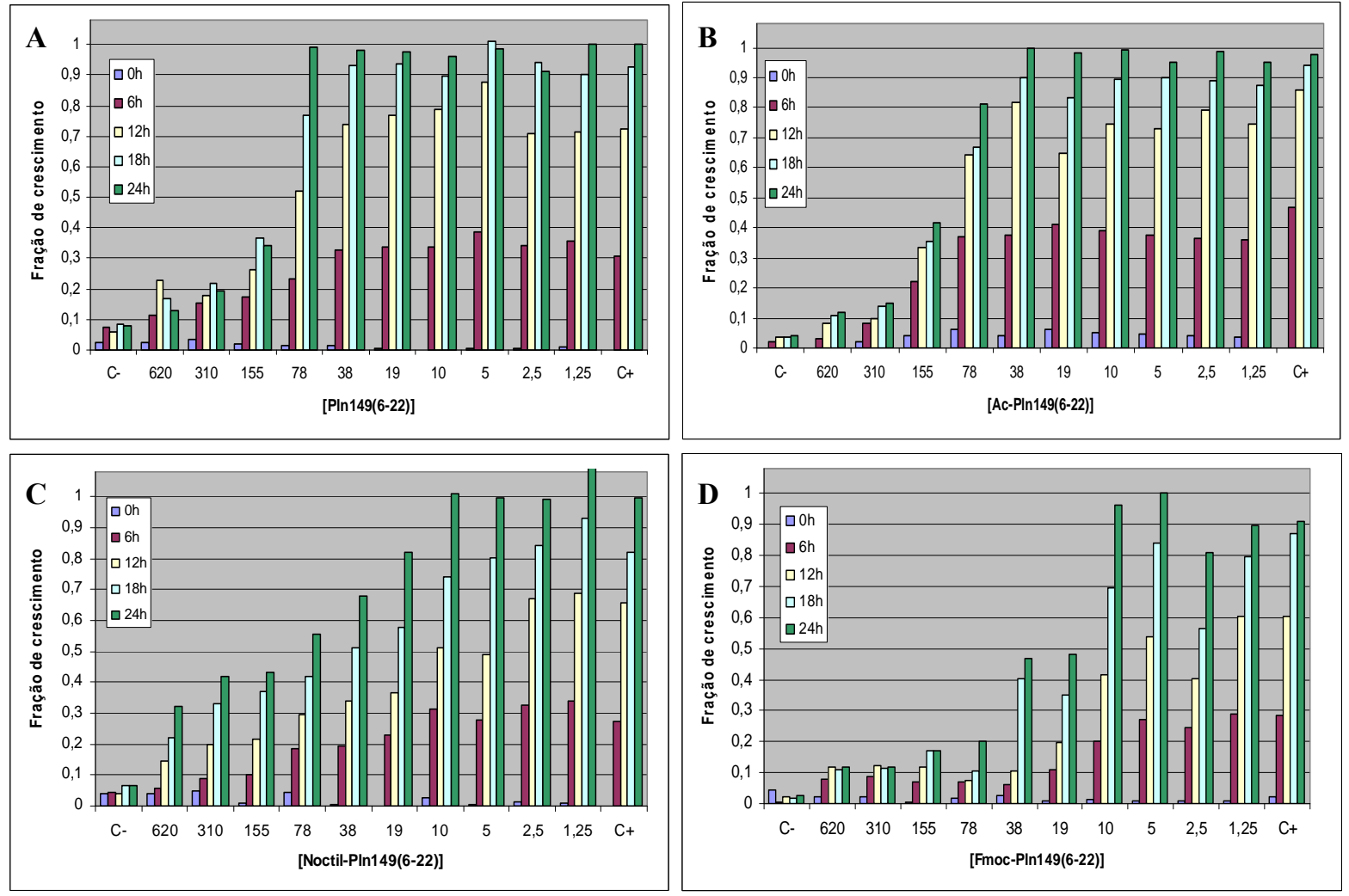

Figura 22 - Curvas de crescimento de P. aeruginosa. Ensaio realizado na presença de diferentes concentrações dos peptídeos análogos do grupo II. (A) Pln149(6-22), (B) Ac-Pln149(6-22) (C) Noctil- Pln149(622) e (D) Fmoc-Pln149(6-22).

O incremento na atividade antimicrobiana observado para o análogo-Fmoc frente aos demais análogos pode ser atribuído ao efeito lítico que o grupo hidrofóbico inserido na sua porção N-terminal causa nas membranas celulares. A adição deste grupo aumenta muito o caráter hidrofóbico do peptídeo. Além do aumento na inibição do crescimento bacteriano, este análogo também teve sua atividade hemolítica elevada (observado na seção 3.2.10.1). Similar comportamento já foi observado para outros AMPs que tiveram seu momento hidrofóbico aumentado (93).

O subcultivo de cada um dos poços deste ensaio (Figura 23) evidenciou uma diferença marcante entre a ação de Pln149a e estes análogos. Essa diferença está no mecanismo de ação entre os peptídeos Pln149a e Pln149(6-22), onde o primeiro mostrou-se bactericida, e este último promoveu uma inibição apenas basteriostática tanto contra $S$. aureus como para $P$. aeruginosa. Nesta figura, pode-se notar o crescimento de colônias bacterianas para os poços onde havia ocorrido inibição do crescimento bacteriano por valores maiores que $90 \%$, tanto para S.aureus, como para P.aeruginosa, isto mostra que apesar da inibição do crescimento destas células, elas permaneceram viáveis, e voltaram a crescer na placa do subcultivo. 


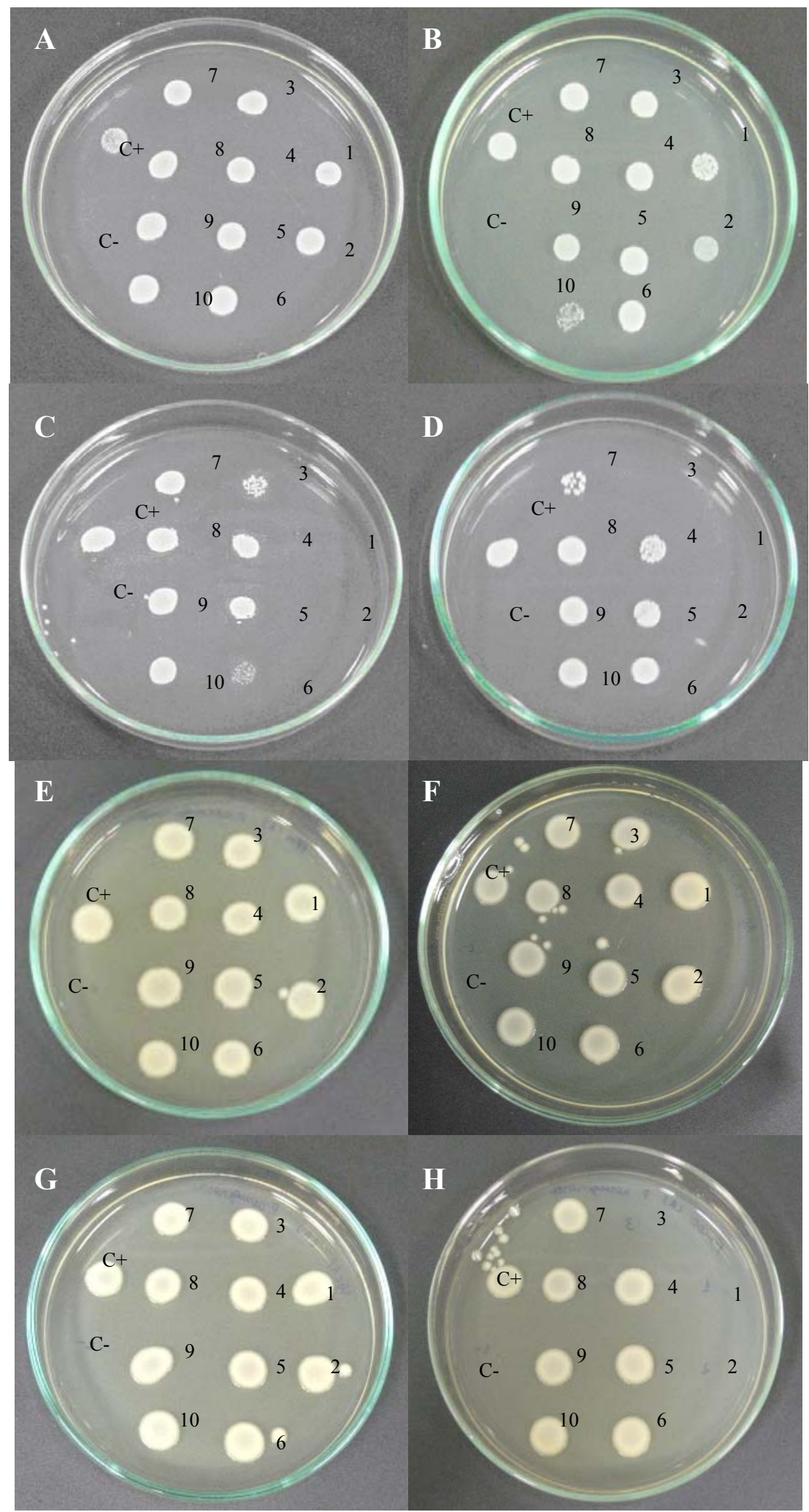

Figura 23 - Subcultivo dos poços do ensaio de MIC. Ensaio realizado contra S.aureus para (A) Pln149(6-22), (B) Ac- Pln149(6-22), (C) Noctil-Pln149(6-22) e (D) Fmoc Pln149(6-22) e contra P.aeruginosa para (E) Pln149(6-22), (F) Ac- Pln149(6-22), (G) Noctil-Pln149(6-22) e (H) Fmoc Pln149(6-22).

Tal diferença no mecanismo de ação de Pln149a e Pln149S comparado com o mecanismo dos peptídeos do grupo II pode ser atribuída à ausência dos resíduos da porção N- 
terminal (YSLQM) nestes últimos, uma vez que esta região deve ser a responsável pela penetração do AMP entre cadeias acil-graxas dos fosfolipídios, promovendo a lise e morte das células. Além disso, os outros análogos apresentaram valores da $\mathrm{MIC}_{50}$ inferiores aos de Pln149a, sugerindo, mais uma vez a importância da participação do segmento N-terminal de Pln149 em sua atividade lítica frente às em membranas biológicas.

\subsection{3 - Atividade contra Saccharomices cerevisiae}

O peptídeo Pln149a também mostrou inibir o crescimento de células de Saccharomyces cerevisiae em meio YPD por até $16 \mathrm{~h}$, de acordo com o decréscimo de $82 \%$ da turbidez em $600 \mathrm{~nm}$ no ensaio de inibição comparado com a cultura controle. Mesmo após a incubação por 24 h, pôde-se notar uma redução do crescimento de 47\% (Figura 24), sugerindo a provável resistência do peptídeo à ação proteolítica desta levedura no meio de cultura, mesmo após $24 \mathrm{~h}$ de incubação.

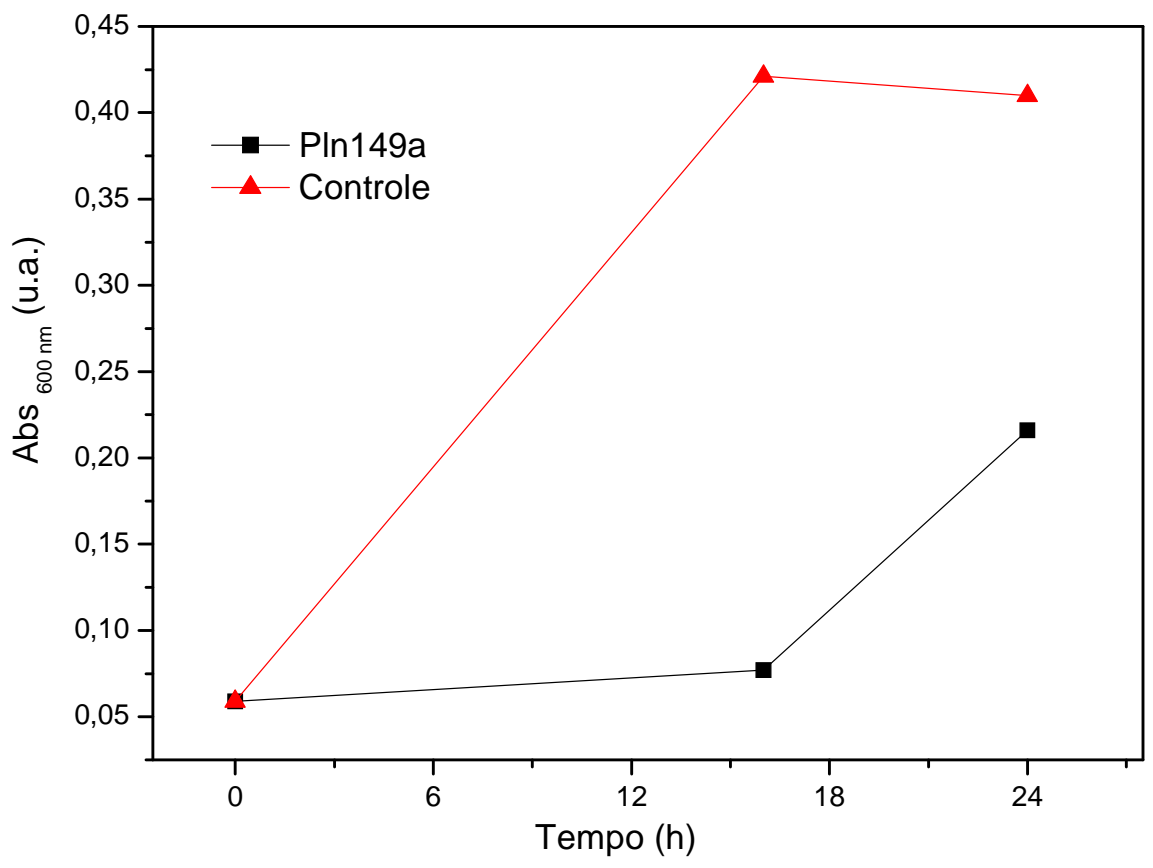

Figura 24 - Ensaio de inibição do crescimento de Saccharomyces cerevisiae. Realizado em meio de cultura YPD líquido, monitorando o crescimento por medidas da absorbância em $600 \mathrm{~nm}$, por 24 horas. 
Uma vez constatada a ação inibidora do peptídeo sobre S.cerevisiae, partiu-se para monitorar as possíveis alterações morfológicas que Pln149a pudesse causar nessas leveduras durante sua ação antimicrobiana, pela técnica de microscopia eletrônica de varredura.

\section{4.3.1 - Microscopia Eletrônica de Varredura}

As imagens tomadas pela técnica de MEV auxiliaram na visualização do efeito do peptídeo Pln149a sobre as células de S.cerevisiae, mostrando mostraram que nas alíquotas em que a levedura foi incubada juntamente com o peptídeo, poucas células intactas foram notadas sobre a superfície da membrana, quando comparamos com o número de células crescidas na ausência do peptídeo. Este número de células intactas foi diminuindo ao longo do tempo de incubação com o peptídeo, no qual após 24 h de incubação, raramente foram observadas células da levedura com a aparência normal.

Conforme pode ser visto na Figura 25A, logo nas alíquotas com tempo de crescimento de 6 horas, as células do controle apresentam crescimento normal com um aspecto túrgido, enquanto as células crescidas na presença do peptídeo, mostraram algumas diferenças morfológicas bruscas em sua superfície (Figura 25B). Estas alterações podem indicar que Pln149a conseguiu alcançar a membrana plasmática da levedura e se acumular nesta superfície, possívelmente promovendo o vazamento do conteúdo citoplasmático, bem como a formação estruturas de diferentes aspectos morfológicos e até de formato multiglobular na superfície das células (Figura 25C), tais estruturas são provenientes dos lipídios removidos da membrana de S.cerevisiae. Conforme já dito, ao longo do tempo, para as alíquotas tomadas em 12 e $24 \mathrm{~h}$ de incubação, essas diferenças foram se acentuando cada vez mais nas células que restaram, indicando que o peptídeo conseguiu atravessar a barreira física definida pela parede celular da levedura e interagir com os fosfolipídios da membrana celular da célula. Nesta interação, Pln149a desempenhou seu papel lítico, rompendo as bicamadas lipídicas nas células da levedura. 

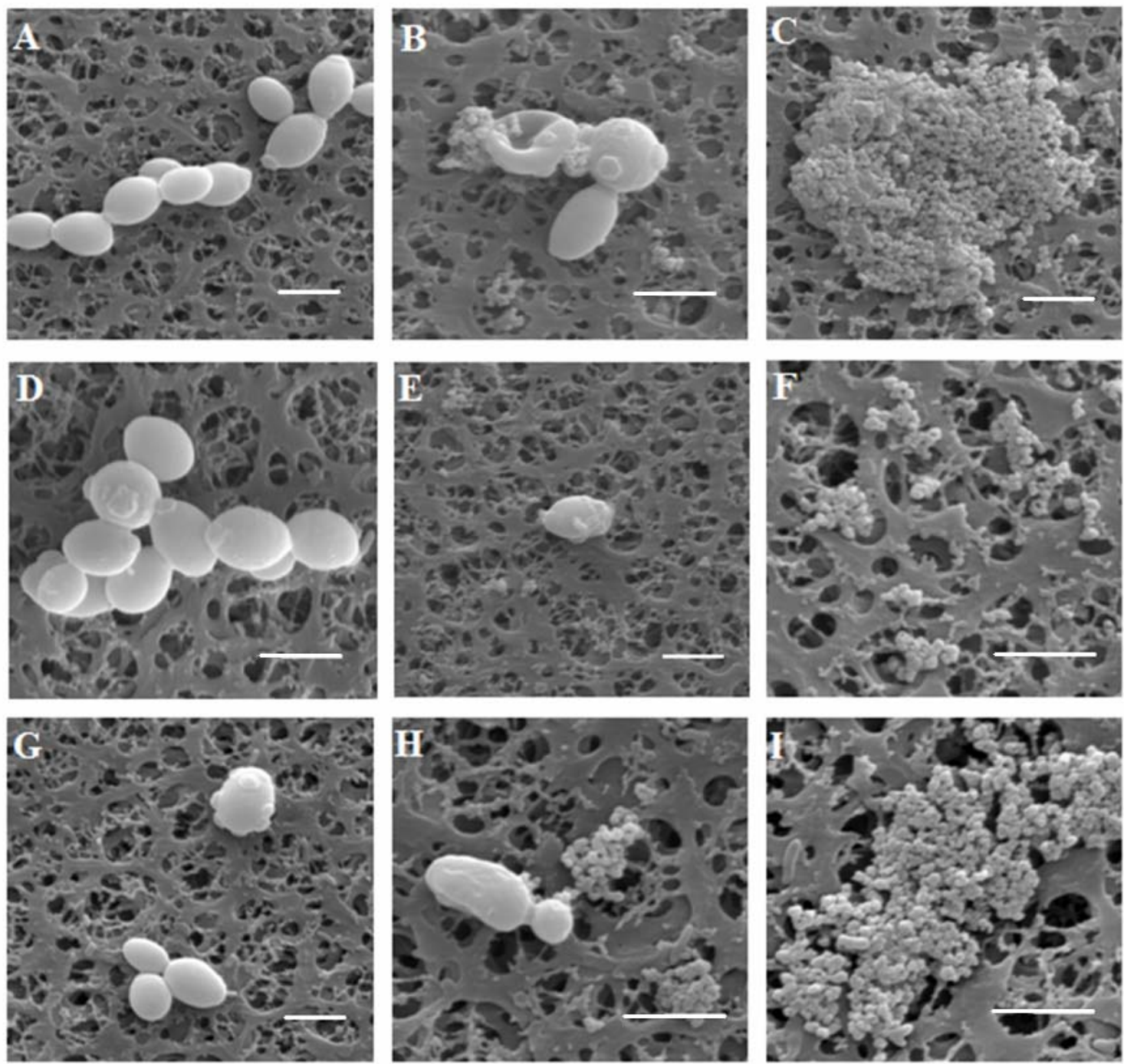

Figura 25 - Imagens de microscopia eletrônica de varredura sobre células de S.cerevisiae crescidas na ausência e na presença de PIn149a. Controles: A, D e G, com 6, 12 e 24 horas de crescimento, respectivamente. Em B e C, E e F, H e I, estão as imagens com 6, 12 e 24 horas de incubação com Pln149a. As barras correspondem a $5 \mu \mathrm{m}$.

A escolha da levedura de S.cerevisiae para realizar as medidas de MEV foi baseada em varias vantagens que estas células nos oferecem; tais como, serem amplamente utilizadas como modelo experimental eucariótico em estudos biológicos básicos e aplicados (94-96); ser constituída de uma única célula, geralmente oval ou esférica de tamanho fácil de ser visualizado; desempenham um importante papel nos processos biotecnológicos; possuem ampla aplicação na indústria alimentícia (fabricação de pão, cerveja, vinho e também como probióticos para animais e humanos); alem de ser uma levedura não-patogênica de fácil cultivo em laboratório. 


\section{4.4 - Células Tumorais}

A fim de avaliar a viabilidade das células de câncer de próstata da linhagem DU-145 após incubação com os peptídeos, a absorbância da cultura foi monitorada em $595 \mathrm{~nm}$, a fim de detectar o MTT (3-(4,5-dimethylthiazol-2-yl)-2,5-difeniltetrazolium bromide) metabolizado na mitocôndria das células viáveis. Como detecção de toxicidade, um controle positivo foi empregado utilizando a mitomycina (molécula tóxica a estas células). Os ensaios com Pln149a e os demais peptídeos análogos mostraram que não há feito citotóxico contra estas células quando os peptídeos estão em concentrações na ordem de nanomolares (Figura 26A). Enquanto que, nas concentrações mais elevadas (de 1 a $20 \mu \mathrm{M}$ ), foi possível observar uma significativa diminuição no número de células viáveis no final do ensaio, conforme mostrado na Figura 26B.
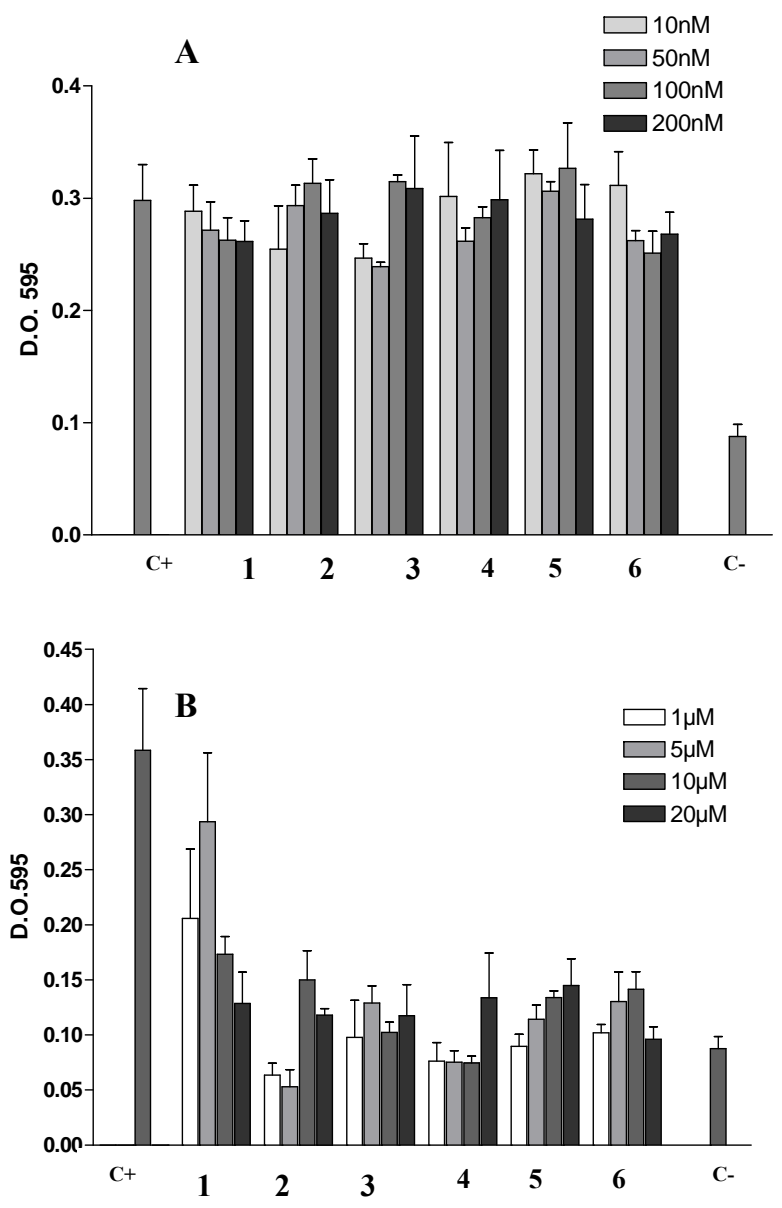

Figura 26 - Ensaio de citotoxicidade em células de câncer de próstata da linhagem DU-145. C $+=$ meio de cultura; C-=mitomicina; $1=$ Pln149a; 2=Pln149S; 3= Pln149(6-22); 4=Ac-Pln149(6-22); 5= FmocPln149(6-22); 6= Noctil-Pln149(6-22). 


\subsection{Espectroscopia de dicroísmo circular (CD)}

\subsubsection{Peptídeos em solução aquosa}

Os espectros de CD no UV-distante de Pln149a e cada uma das moléculas sintetizadas registrados em água em tampão Hepes $10 \mathrm{mM}$ (pH 7.4) são caracterizados pela presença de apenas um mínimo negativo centrado em torno de $198 \mathrm{~nm}$. Este perfil é típico para proteínas e peptídeos do tipo $\beta_{\text {III }}$, que são descritos na literatura por conterem uma alta fração de elementos em estruturas não-ordenadas e apresentarem ausência de estrutura secundária do tipo helicoidal ( $\alpha$-hélices), conforme mostrado na Figura 27. Dessa forma, observa-se que, em solução aquosa, estes peptídeos assumem predominantemente estrutura secundária do tipo desordenada.

O baixo grau de ordenamento estrutural destes peptídeos em solução aquosa, é uma característica compartilhada com uma classe de proteínas conhecida como proteínas desordenadas (97), que apresenta alta flexibilidade estrutural devido à presença de grandes segmentos em estrutura randômica, o que permite o estabelecimento de ligações com um número grande de diferentes alvos. Este artifício é proposto como a alternativa usada por muitas proteínas virais a fim de expandir sua funcionalidade sem um simultâneo aumento no tamanho do genoma.

O cálculo das frações de estrutura secundária, realizado para a Pln149a utilizando os programas ContinLL, SELCON3 e CDSSTR, resultaram nos valores médios de $43 \%$ em estruturas desordenadas, $24 \%$ em voltas- $\beta$ e $28 \%$ de estruturas- $\beta$. A desconvolução dos espectros dos peptídeos análogos foram muito semelhantes ao da Pln149a, a analise dos seus conteúdos em estrutura secundária, com base no pacote CDPro realizadas com a base de dados contendo 56 proteínas, estão na Tabela 8. 

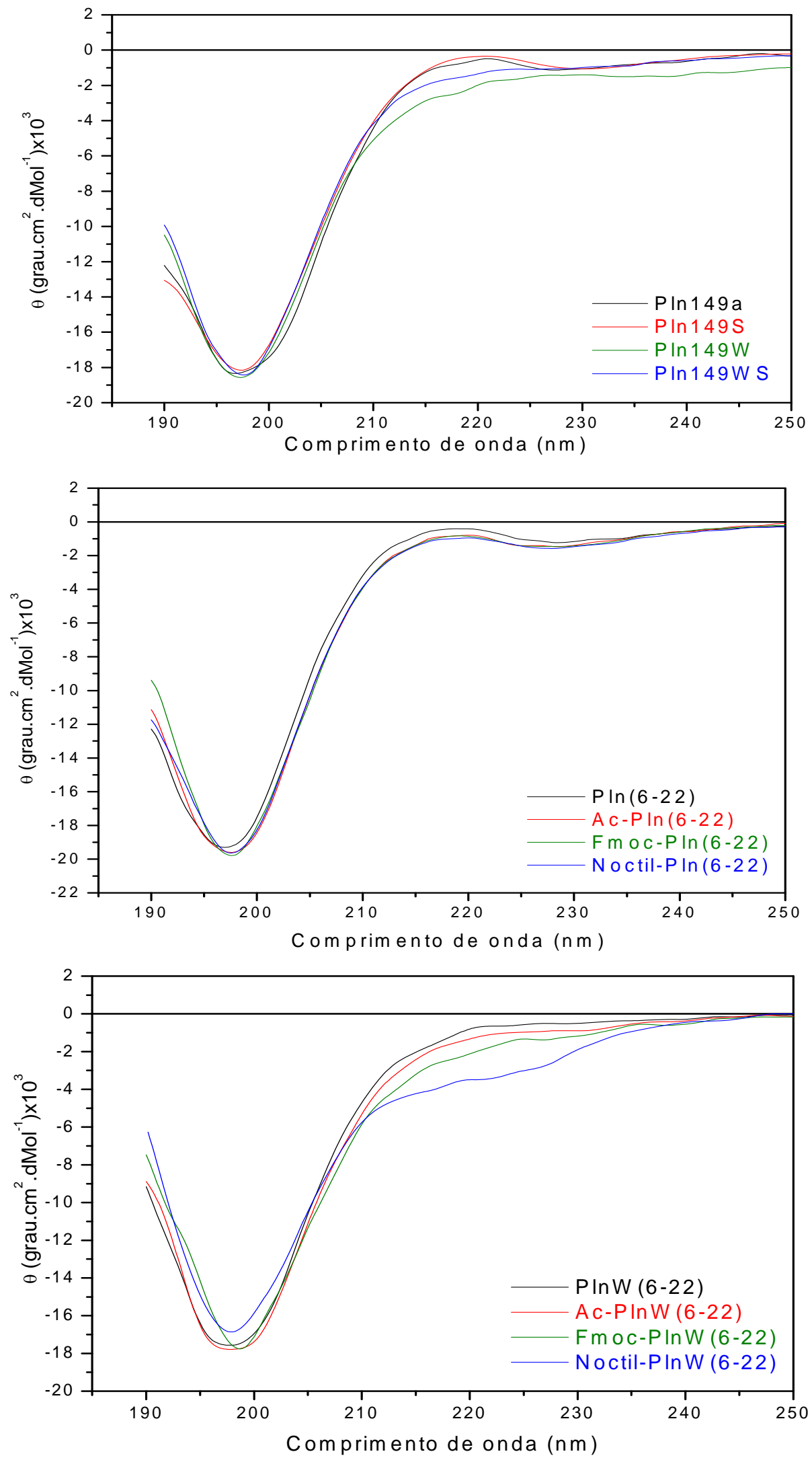

Figura 27 - Espectro de CD no UV distante de PIn149a e dos peptídeos modificados. As amostras $(0.2$ $\mathrm{mg} / \mathrm{mL}$ ) foram analisadas em água, com uma média de 16 varreduras, a $25{ }^{\circ} \mathrm{C}$, numa cubeta retangular de caminho óptico de $1 \mathrm{~mm}$. 
Tabela 8 - Conteúdos de estrutura secundária dos peptídeos em solução aquosa. n.d. = não determinado

\begin{tabular}{|c|c|c|c|}
\hline Peptídeo & Continll & Selcon3 & CDSSTR \\
\hline \multirow[t]{4}{*}{$\mathrm{Pln} 149 \mathrm{a}$} & $\alpha$-hélice: 6\% & $\alpha$-hélice: 8\% & $\alpha$-hélice: $2 \%$ \\
\hline & Estruturas- $\beta$ : $25 \%$ & Estruturas- $\beta$ : $25 \%$ & Estruturas- $\beta$ : $34 \%$ \\
\hline & Voltas: $25 \%$ & Voltas: $24 \%$ & Voltas: $22 \%$ \\
\hline & Desordenada: $44 \%$ & Desordenada: $43 \%$ & Desordenada: $42 \%$ \\
\hline \multirow[t]{4}{*}{ Pln149S } & $\alpha$-hélice: 7\% & $\alpha$-hélice: 7\% & $\alpha$-hélice: $2 \%$ \\
\hline & Estruturas- $\beta$ : $25 \%$ & Estruturas $-\beta: 25 \%$ & Estruturas- $\beta$ : $33 \%$ \\
\hline & Voltas: $24 \%$ & Voltas: $24 \%$ & Voltas: $25 \%$ \\
\hline & Desordenada: $44 \%$ & Desordenada: $44 \%$ & Desordenada: $4 \odot \%$ \\
\hline \multirow[t]{4}{*}{$P \ln 149 W$} & $\alpha$-hélice: 6\% & $\alpha$-hélice:6\% & $\alpha$-hélice: $2 \%$ \\
\hline & Estruturas- $\beta$ : $24 \%$ & Estruturas- $\beta: 26 \%$ & Estruturas- $\beta$ : $32 \%$ \\
\hline & Voltas: $25 \%$ & Voltas: $24 \%$ & Voltas: $26 \%$ \\
\hline & Desordenada: $45 \%$ & Desordenada: $44 \%$ & Desordenada: $4 \odot \%$ \\
\hline \multirow[t]{4}{*}{ Pln149WS } & $\alpha$-hélice: 6\% & n.d. & $\alpha$-hélice: 2\% \\
\hline & Estruturas- $\beta$ : $28 \%$ & & Estruturas- $\beta$ : $33 \%$ \\
\hline & Voltas: $23 \%$ & & Voltas: $24 \%$ \\
\hline & Desordenada: $43 \%$ & & Desordenada: $41 \%$ \\
\hline \multirow[t]{4}{*}{$P \ln 149(6-22)$} & $\alpha$-hélice: $7 \%$ & n.d. & $\alpha$-hélice: $1 \%$ \\
\hline & Estruturas- $\beta$ : $25 \%$ & & Estruturas- $\beta$ : $34 \%$ \\
\hline & Voltas: $23 \%$ & & Voltas: $24 \%$ \\
\hline & Desordenada: $45 \%$ & & Desordenada: $41 \%$ \\
\hline \multirow[t]{4}{*}{ Ac-Pln149(6-22) } & $\alpha$-hélice: $6 \%$ & n.d. & $\alpha$-hélice: 2\% \\
\hline & Estruturas- $\beta$ : $24 \%$ & & Estruturas- $\beta$ : $35 \%$ \\
\hline & Voltas: $24 \%$ & & Voltas: $24 \%$ \\
\hline & Desordenada: $46 \%$ & & Desordenada: $39 \%$ \\
\hline \multirow[t]{4}{*}{ Noctil-Pln149(6-22) } & $\alpha$-hélice: 7\% & $\alpha$-hélice: 9\% & $\alpha$-hélice: $1 \%$ \\
\hline & Estruturas- $\beta$ : $23 \%$ & Estruturas- $\beta$ : $26 \%$ & Estruturas- $\beta$ : $34 \%$ \\
\hline & Voltas: $24 \%$ & Voltas: $23 \%$ & Voltas: $24 \%$ \\
\hline & Desordenada: $46 \%$ & Desordenada: $42 \%$ & Desordenada: $41 \%$ \\
\hline \multirow[t]{4}{*}{ Fmoc-Pln149(6-22) } & $\alpha$-hélice: 7\% & n.d. & $\alpha$-hélice: $2 \%$ \\
\hline & Estruturas- $\beta$ : $26 \%$ & & Estruturas- $\beta$ : $35 \%$ \\
\hline & Voltas: $23 \%$ & & Voltas: $24 \%$ \\
\hline & Desordenada: $44 \%$ & & Desordenada: $39 \%$ \\
\hline \multirow[t]{4}{*}{ Pln149W(6-22) } & $\alpha$-hélice: 6\% & $\alpha$-hélice: 9\% & $\alpha$-hélice: 2\% \\
\hline & Estruturas- $\beta$ : $28 \%$ & Estruturas- $\beta: 30 \%$ & Estruturas- $\beta$ : $34 \%$ \\
\hline & Voltas: $23 \%$ & Voltas: $22 \%$ & Voltas: $24 \%$ \\
\hline & Desordenada: $43 \%$ & Desordenada: $39 \%$ & Desordenada: $40 \%$ \\
\hline \multirow[t]{4}{*}{ Ac-Pln149W(6-22) } & $\alpha$-hélice: $7 \%$ & n.d. & $\alpha$-hélice: $2 \%$ \\
\hline & Estruturas- $\beta$ : $28 \%$ & & Estruturas- $\beta$ : $33 \%$ \\
\hline & Voltas: $23 \%$ & & Voltas: $24 \%$ \\
\hline & Desordenada: $42 \%$ & & Desordenada: $41 \%$ \\
\hline \multirow[t]{4}{*}{ Noctil-Pln149W(6-22) } & $\alpha$-hélice: 8\% & $\alpha$-hélice: 7\% & $\alpha$-hélice: 6\% \\
\hline & Estruturas- $\beta$ : $23 \%$ & Estruturas- $\beta$ : $27 \%$ & Estruturas- $\beta$ : $31 \%$ \\
\hline & Voltas: $25 \%$ & Voltas: $22 \%$ & Voltas: $26 \%$ \\
\hline & Desordenada: $44 \%$ & Desordenada: $44 \%$ & Desordenada: $37 \%$ \\
\hline \multirow[t]{4}{*}{ Fmoc-Pln149W(6-22) } & $\alpha$-hélice: 7\% & $\alpha$-hélice: 9\% & $\alpha$-hélice: $3 \%$ \\
\hline & Estruturas- $\beta$ : $29 \%$ & Estruturas- $\beta$ : $29 \%$ & Estruturas- $\beta$ : $33 \%$ \\
\hline & Voltas: $23 \%$ & Voltas: $22 \%$ & Voltas: $24 \%$ \\
\hline & Desordenada: $41 \%$ & Desordenada: $40 \%$ & Desordenada: $40 \%$ \\
\hline
\end{tabular}




\subsubsection{Presença de Metanol}

Estudando o efeito da composição do solvente sobre a estrutura do peptídeo Pln149a pela técnica de $\mathrm{CD}$, observamos que as adições de 5, 10 e 20\% de metanol não causaram mudanças significativas no perfil do espectro de Pln149a em solução aquosa (Figura 28A). Todavia, quando o peptídeo foi incubado com concentrações mais altas de metanol (a partir de $40 \%$, mas acentuando-se com $80 \%$ e $90 \%$ ), diferenças marcantes puderam ser observadas nesses espectros. A primeira delas foi o aumento da intensidade da banda em 222 à medida que se aumentou a concentração de metanol, refletindo o aumento do conteúdo helicoidal na estrutura secundária de Pln149a (Figura 28B). Outra diferença foi o deslocamento da banda que anteriormente estava centrada em $198 \mathrm{~nm}$ para a região de $208 \mathrm{~nm}$, também característica do conteúdo helicoidal que foi induzido no peptídeo.

Nas altas concentrações de metanol, o espectro de CD de Pln149a apresentou-se inteiramente com as bandas características de elementos em $\alpha$-hélice, sendo os dois mínimos já citados (em 222 e $208 \mathrm{~nm}$ ) e um máximo positivo em torno de $196 \mathrm{~nm}$.

Este mesmo comportamento é observado em dermaseptinas isoladas de Phyllomedusa oreades e Phyllomedusa distincta quando na presença de TFE. Além disso, também é conhecido que a adição de detergentes aniônicos, tais como o SDS, acima da concentração micelar critica (CMC), faz com que o espectro de CD de tais AMPs sofra um aumento característico do conteúdo de estruturas helicoidais (98).

A indução de elementos helicoidais na estrutura secundária dos peptídeos promovida pela incubação com metanol pode ser explicada pelo aumento do caráter apolar do meio, uma vez que as ligações de hidrogênio intramoleculares (que ajudam a estabilizar a estrutura helicoidal) têm uma propensão muito maior de se formarem quando a molécula é colocada em meios (solventes) com baixa capacidade de formar ligações de hidrogênio. 

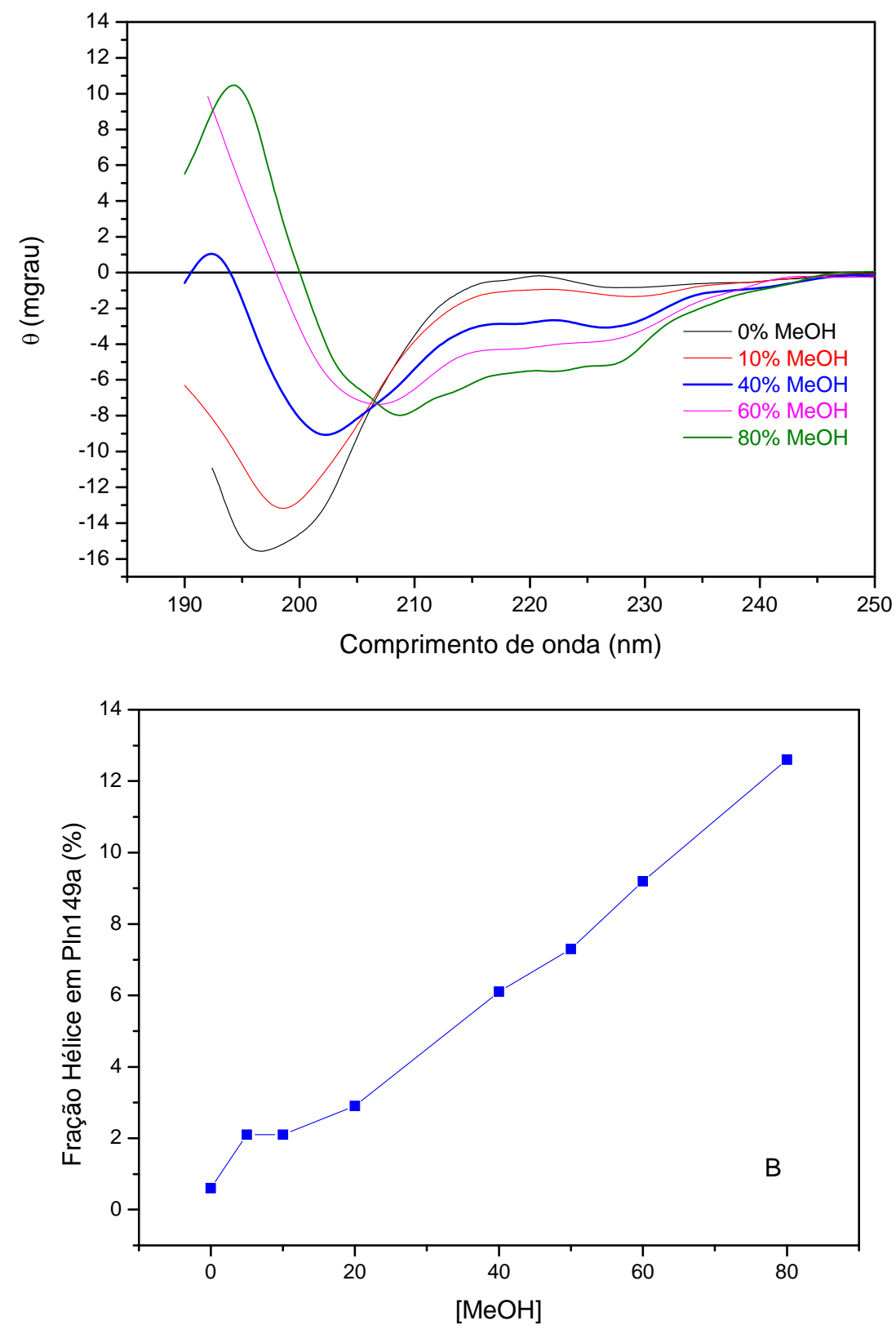

Figura 28 - Espectros de CD de PIn149a com diferentes composições de metanol. (A) Os espectros de Pln149a incubados com $0,10,40,60$ e 80\% de metanol mostram a indução de um conteúdo helicoidal no peptídeo. (B) A fração helicoidal em Pln149a é proporcional ao aumento da concentração de metanol no meio.

\section{5.3 Presença de Carboidratos}

O espectro de CD de Pln149a na presença dos diferentes carboidratos (glicose, galactose, manose, maltose, sacarose, $\alpha$-metil-manosídeo, N-acetil-galactosamina, carragenana e galactomanana) não apresentou nenhuma diferença significativa do espectro do peptídeo em solução aquosa (Figura 29), preservando a banda característica de elementos em estrutura 
randômica observada por volta de $198 \mathrm{~nm}$, mostrando que o peptídeo não sofreu nenhuma mudança conformacional brusca na presença destes carboidratos. Isso pode indicar uma interação que não seja capaz de induzir uma maior estruturação do peptídeo, ou então, a ausência de interação entre as duas moléculas.

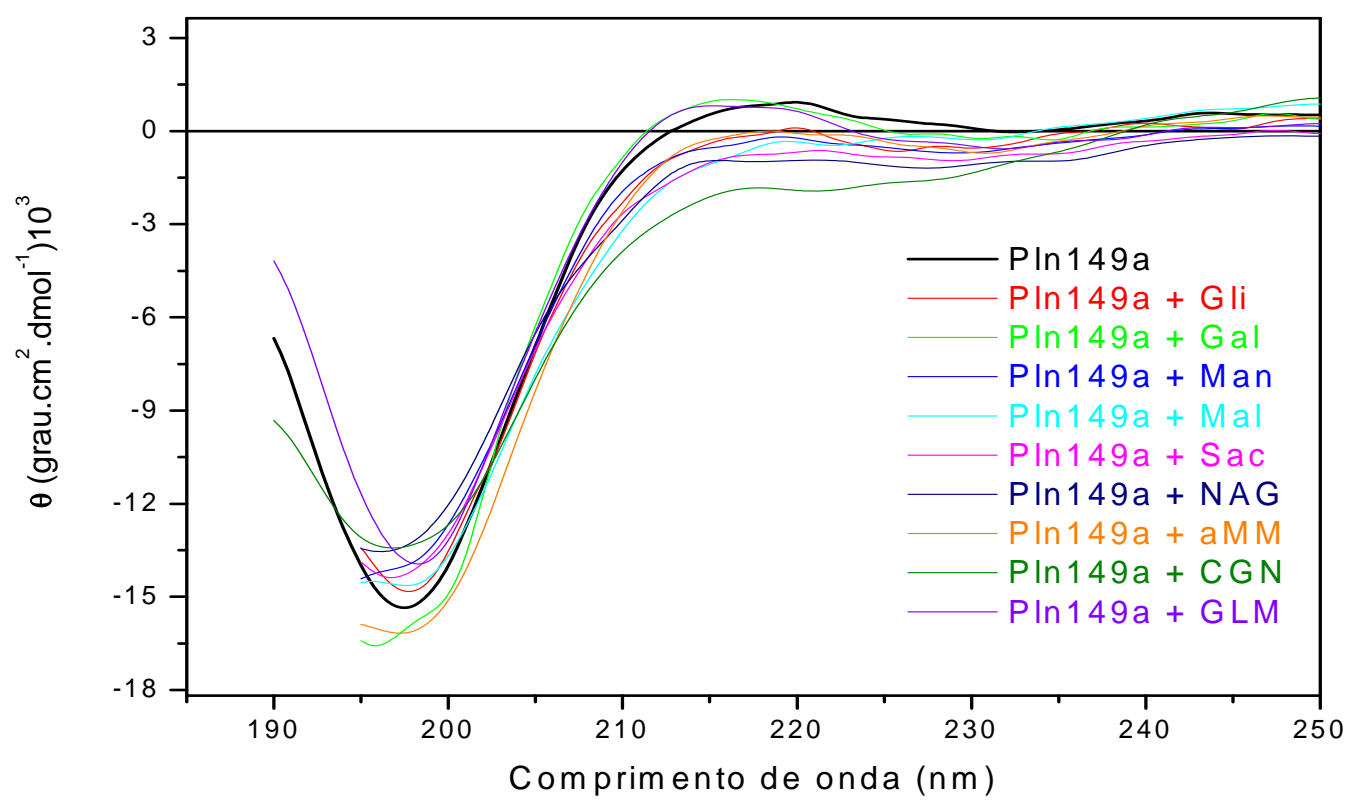

Figura 29 - Pln149a na presença de diferentes carboidratos. O espectro de CD de Pln149a $(0.2 \mathrm{mg} / \mathrm{mL})$ foi tomado a $25^{\circ} \mathrm{C}$, numa média de 8 varreduras. Todos os carboidratos foram utilizados numa concentração de $0.1 \mathrm{M}$ e seus respectivos espectros de CD foram subtraídos do peptídeo. Abreviaturas: Gli: glicose, Gal: galactose, Man: manose, Mal: maltose, Sac: Sacarose, NAG: Nacetil-glicosamina, aMM: $\alpha$-metil-manosideo, CGN: carragenana, GLM: galactomanana.

\section{5.4 Presença de vesículas fosfolipídicas}

A interação de Pln149a com modelos de membrana constituídos de bicamadas fosfolipídicas foi também investigada pela técnica de dicroísmo circular. A preferência na utilização dos sistemas modelo de membrana se deu em vista a alta complexidade das membranas biológicas naturais, que dificultariam o estudo de eventos independentes e controlados. Além da obtenção não-trivial das biomembranas naturais que contrastam com a facilidade de construção destes sistemas biomiméticos, onde é possível utilizar fosfolipídios com propriedades ácidas, neutras, além da presença de colesterol e marcadores específicos. Tais vantagens são responsáveis pela grande utilização de modelos de membrana nos diferentes estudos em que são empregados, onde as interações moleculares dos peptídeos com 
lipídios são passíveis de serem estudadas por diferentes técnicas físicas, tais como as espectroscopias de emissão de fluorescência, de absorção eletrônica (UV-Visível), de dicroísmo circular, as diferentes modalidades de microscopia, calorimetria, ressonância plasmônica de superfície e ressonância magnética nuclear.

A Figura 30 mostra os espectros do peptídeo em solução aquosa e na presença das LUVs de DPPG, DPPC, POPG, DLPC, DPPE, DMPE, DSPE e DPPS a $25^{\circ} \mathrm{C}$. Nela, observase que não ocorre nenhuma mudança conformacional durante a interação de Pln149a com lipossomos zwitteriônicos, tais como as vesículas constituídas por fosfolipídios da série PC e PE.

No entanto, realizando o mesmo experimento com vesículas de DPPG e POPG, o peptídeo que em solução aquosa apresentava predominantemente estrutura desordenada passou por uma mudança conformacional, sofrendo a indução de um elemento helicoidal em sua estrutura secundária, devido ao espectro típico de proteínas com hélice- $\alpha$.

Mais uma vez, a transição de estrutura desordenada para hélice- $\alpha$ na estrutura secundaria do peptídeo devido a sua interação com superfícies negativamente carregada é observada em muitos AMPs, tais como as dermaseptinas de anfíbios (98), parasina I e peptídeos análogos (99) interagindo com estruturas micelares do detergente negativamente carregado SDS.

A flexibilidade estrutural do AMP é um aspecto importante na ação do peptídeo, uma vez que costuma ocorrer uma transição conformacional entre a estrutura do peptídeo em solução e o peptídeo ligado à membrana plasmática.

A bicamada fosfolipídica, componente essencial a todas as biomembranas, é uma estrutura anfipática, apresentando tanto domínios hidrofílicos como hidrofóbicos. A rede de cargas de uma biomembrana é determinada basicamente pela sua composição fosfolipídica e por sua arquitetura, e isso explica o motivo das biomembranas dos organismos procariotos serem significativamente distintas das células eucarióticas. Lipídios do tipo fosfatidilcolina (PC) e fosfatidiletanolamina (PE), por exemplo, não apresentam uma rede de cargas líquida, formando bicamadas enriquecidas de fosfolipídios zwitteriônicos. A camada externa das membranas de células de mamíferos é composta majoritariamente por fosfolípidos zwitterionicos, para os quais os AMPs mostram baixa afinidade. A presença de colesterol também contribui para uma menor interação das membranas eucarióticas com esses peptídeos. 

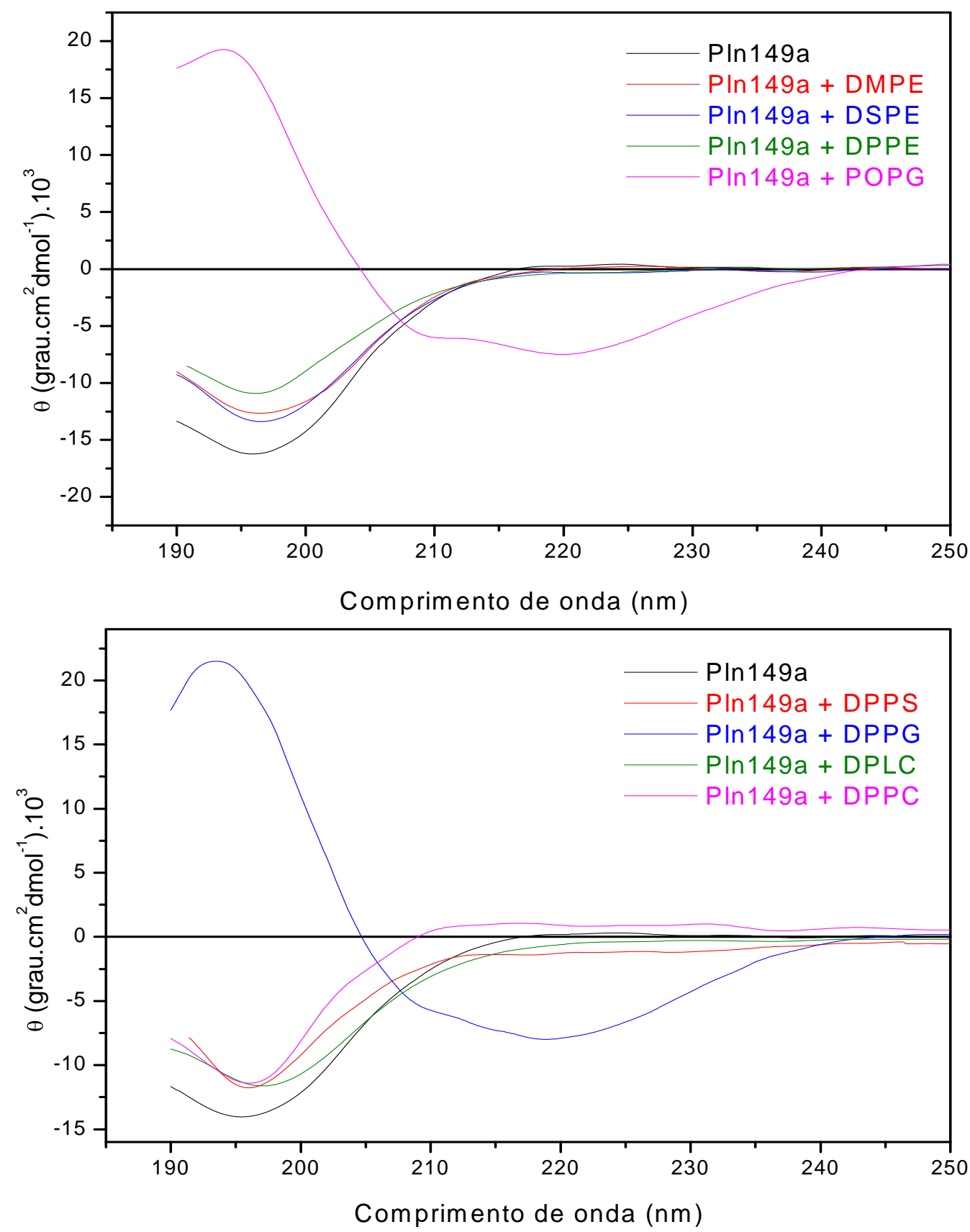

Figura 30 - Espectro de CD da interação de PIn149a com diferentes LUVs. Os espectros foram tomados numa cubeta retangular de caminho óptico de $1 \mathrm{~mm}$, com uma média de 16 varreduras. O peptídeo $(0.2 \mathrm{mg} / \mathrm{mL})$ foi incubado com as LUVs de DPPG, DPPC, DLPC, DPPE, DMPE, DSPE e DPPS.

Ao contrário, os fosfolipídios hidroxilados, tais como o fosfatidilglicerol (PG), mantêm uma rede de cargas negativas em condições fisiológicas. Deste modo, membranas celulares compostas predominantemente de PG tendem a ser altamente eletronegativas, estas composições são encontradas em muitas bactérias patogênicas (84), onde os peptídeos catiônicos ligam-se preferencialmente com ajuda de interações eletrostáticas. 
O valor médio dos três programas de desconvolução para o cálculo das frações de estrutura secundária de Pln149a incubada com LUVs de DPPC mostram 41\% elementos desordenados, $24 \%$ de voltas e $31 \%$ elementos- $\beta$, enquanto que para as vesículas de DPPG obteve-se $37 \%$ de $\alpha$-hélices, $24 \%$ de estrutura- $\beta, 17 \%$ de voltas- $\beta$ e $22 \%$ de estruturas não ordenadas. Estes valores indicam que cerca $51 \%$ dos elementos em estrutura não-ordenada do Pln149a em solução aquosa sofreu mudança conformacional ao interagir com vesículas de DPPG para se organizar em estrutura helicoidal, além da contribuição também de $11 \%$ das demais frações que também sofreram esta indução.

A hélice que se forma em Pln149a da interação com LUVs de DPPG deve se estender entre os resíduos de aminoácido 10-19, conforme predito pelo modelo (44). Nesta região do peptídeo, uma rede de cargas positivas é formada no lado polar da hélice devido à presença de resíduos positivamente carregados (K11, K14, K15, K18 e K19), o que pode criar um ambiente favorável para interação com espécies negativas. Deste modo, acredita-se que a primeira etapa da interação entre o AMP e as membranas lipídicas do microrganismo seja a estabilização da estrutura helicoidal por meio de interações eletrostática, pois o AMP tem carga líquida positiva em $\mathrm{pH}$ fisiológico e a monocamada externa da membrana citoplasmática de bactérias tem carga liquida negativa. Esse aspecto é importante para a seletividade do AMP, pois o potencial negativo da membrana atua como agente concentrador de peptídeos no entorno da membrana.

Mais uma vez, de modo semelhante aos peptídeos análogos de Pln149, as proteínas desordenadas são geralmente ricas em resíduos carregados, apresentando grandes áreas de contato para interação com outras proteínas e com membrana. A grande densidade de cargas que elas apresentam atua para desestabilizar uma estrutura mais compacta que poderia ser formada nestas proteínas em solução (100). Deste modo, a ligação de uma proteína desordenada ao seu alvo se dá sob uma condição entropicamente desfavorável, pois ocorre o enovelamento da proteína $(\Delta \mathrm{S}<0)$. No entanto, tais proteínas adquirem uma energia livre de ligação $\left(\Delta \mathrm{G}_{\text {bind }}\right)$ favorável pelo alto número de interações eletrostáticas que realizam com a molécula alvo, o que favorece muito a entalpia de ligação ( $\Delta \mathrm{H}$ altamente negativo) de modo a compensar o termo entrópico.

Após a ligação do peptídeo à membrana, ocorrem eventos subseqüentes que causarão a permeabilização e a translocação da membrana microbianas, mas estes mecanismos ainda não estão totalmente esclarecidos e podem variar para diferentes AMPs (84). 
Também foram investigadas pela técnica de $\mathrm{CD}$, as interações de cada um dos outros peptídeos análogos a Pln149a (do grupo I, II), com as LUVs de DPPG e DPPC para determinar como estas modificações afetam a formação da hélice.

Todos os espectros foram tomados nas mesmas condições descritas para Pln149a, e de modo semelhante, não mostraram sofrer nenhuma mudança conformacional na presença de vesículas fosfolipídicas de DPPC, preservando o perfil típico do espectro do peptídeo livre em solução aquosa (Figura 31).
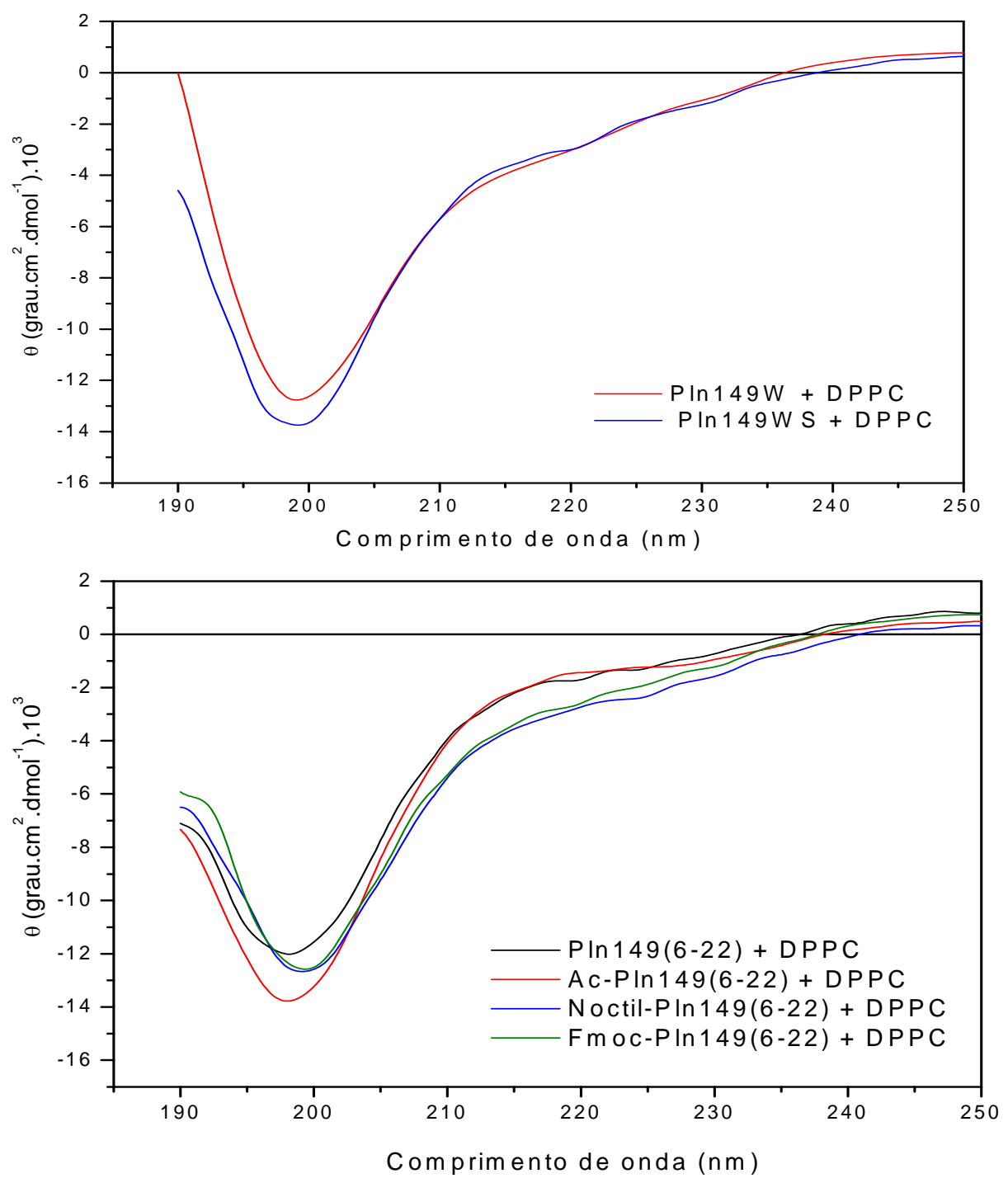

Figura 31 - Espectro de CD da interação dos peptídeos análogos de Pln149 com LUVs de DPPC. Os espectros dos peptídeos análogos a Pln149 quando incubados com vesículas zwiteriônicas não mostram alteração do perfil típico de estrutura randômica que estes peptídeos apresentaram em solução aquosa.

No entanto, na presença de vesículas aniônicas, a indução helicoidal foi observada em todos os outros peptídeos análogos estudados, conforme mostrado na Figura 32. Portanto, as 
modificações inseridas no N-terminal dos análogos não causaram graves perturbações sobre a estrutura secundária do peptídeo, nem dificultaram sua interação com as biomembranas negativas. Nesta figura, observa-se ainda que nos espectros dos análogos cujo pentapeptídeo YSLQM foi removido da porção N-terminal dos peptídeos (análogos do grupo II), houve uma diminuição da intensidade da elipticidade em $222 \mathrm{~nm}$. Desta forma, pode-se inferir que, apesar da participação do pentapeptídeo não ser predita na hélice que se instala na estrutura secundaria de $\mathrm{Pln} 149 \mathrm{a}$, a presença destes 5 resíduos na porção $\mathrm{N}$-terminal da molécula também afeta o conteúdo helicoidal do peptídeo.

A desconvolução dos espectros de Pln149(6-22) e dos demais peptídeos do grupo II na presença das LUVs de DPPG mostram as frações de 22\% de $\alpha$-hélices, $29 \%$ de estrutura- $\beta$, $23 \%$ de voltas- $\beta$ e $26 \%$ de estruturas não ordenadas. Portanto, pode observar que há uma diferença de 16\% do conteúdo helicoidal que é induzido em Pln149a, concordando com ao diminuição da intensidade da banda em $222 \mathrm{~nm}$ para os peptídeos do grupo II.

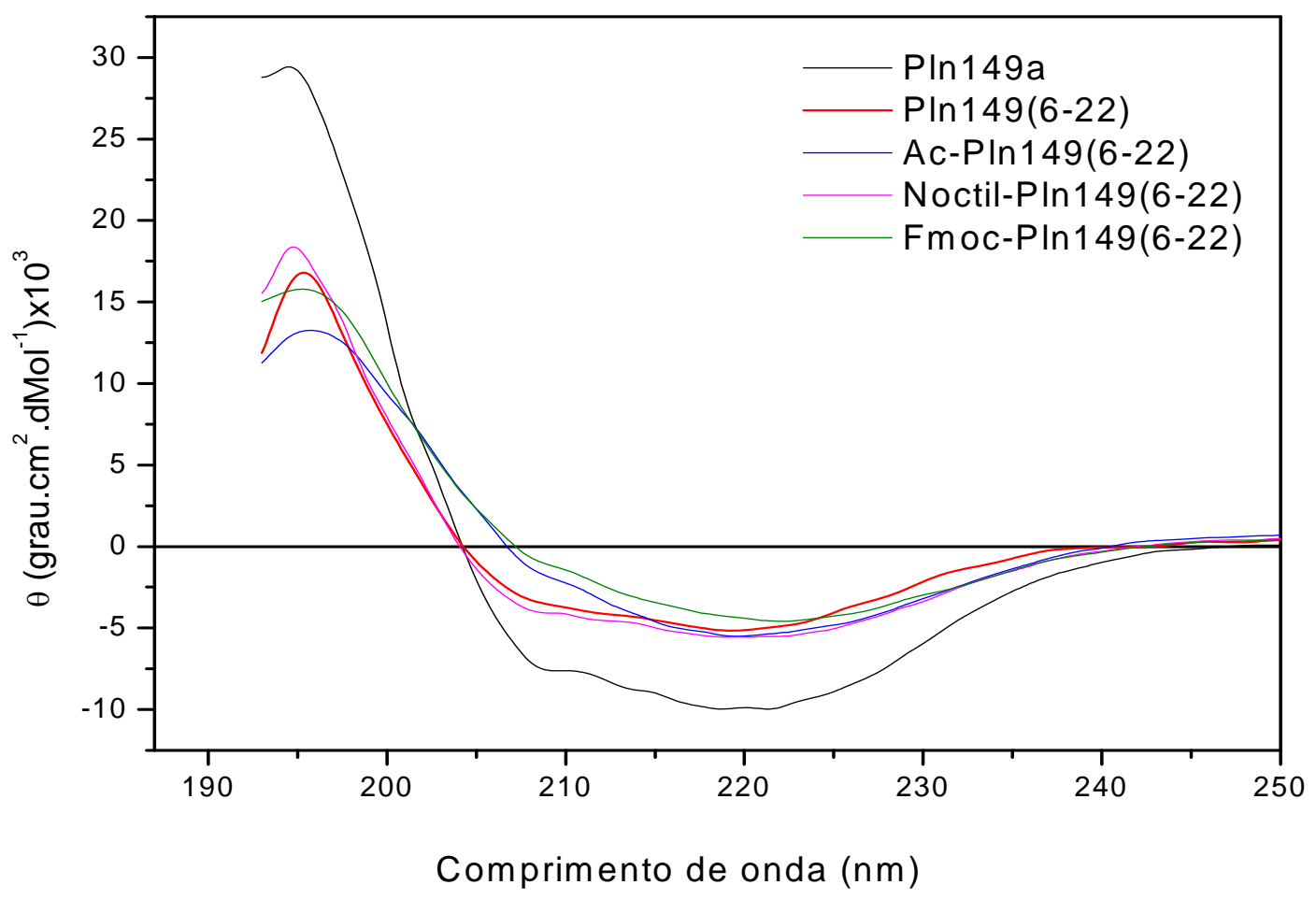

Figura 32 - Espectro de CD da interação dos peptídeos análogos de Pln149 com LUVs de DPPG. Os espectros foram tomados a $25^{\circ} \mathrm{C}$. Uma indução helicoidal é observada decorrente desta interação.

Uma das primeiras observações a respeito de interações peptídeo-lipídio foi que a ligação da cadeia polipeptídica nas membranas lipídicas é geralmente acompanhada pela formação de estrutura secundária organizada no peptídeo. O processo referido como partição, 
ligação e enovelamento surge da necessidade de evitar a exposição dos aminoácidos polares da cadeia principal do peptídeo para o interior da bicamada lipídica, o que minimizaria o número de ligações estabelecidas entre essas duas espécies (3).

\subsubsection{Ensaio frente a variações de pH e força iônica}

A incubação de Pln149a em diferentes valores de $\mathrm{pH}$ (no intervalo de 3.0 a 11) não afetou o grau de desordem do peptídeo em solução, conforme pode ser visto pela Figura 33A, na qual o mesmo perfil de peptídeo em estrutura randômica é observado em todo o intervalo de $\mathrm{pH}$ testado.

Um comportamento dependente do $\mathrm{pH}$ foi observado quando Pln149a foi incubado com vesículas de DPPG, de acordo com os espectros da Figura 33B. Na qual vemos a ocorrência da indução de hélice em Pln149a no intervalo de pH 5.0 a 9.0, enquanto, nos extremos valores ácidos e básicos (pHs 3.0 e 11.0, respectivamente) o peptídeo permanece com estrutura randômica em solução.

Esse efeito pode ser explicado em função da diminuição da atração eletrostática entre o peptídeo e a superfície do lipossomo, devido a modificação das cargas dos grupos carregados tanto do peptídeo quanto das cabeças polares do DPPG nestes valores de $\mathrm{pH}$. Pois em pH 3.0, as hidroxilas do DPPG encontram-se protonadas, diminuindo seu caráter eletronegativo. Já no valor de pH 11, o peptídeo se encontra numa solução acima do seu ponto isoelétrico, fazendo com seu caráter positivo diminua. Em ambos os casos, haverá menor interação entre as duas espécies em solução.

Estudos do mecanismo de ação com lactocinas revelaram que a atividade bactericida estava confinada ao pH 6.0 e valores ligeiramente menores (22). Em geral, a atividade antimicrobiana dos AMPs são maiores em pHs ácidos devido ao seu caráter catiônico, pois o efeito do pH tem um papel importante na determinação da carga efetiva do peptídeo, e esta última é um dos fatores mais importantes para a atividade do AMP. 

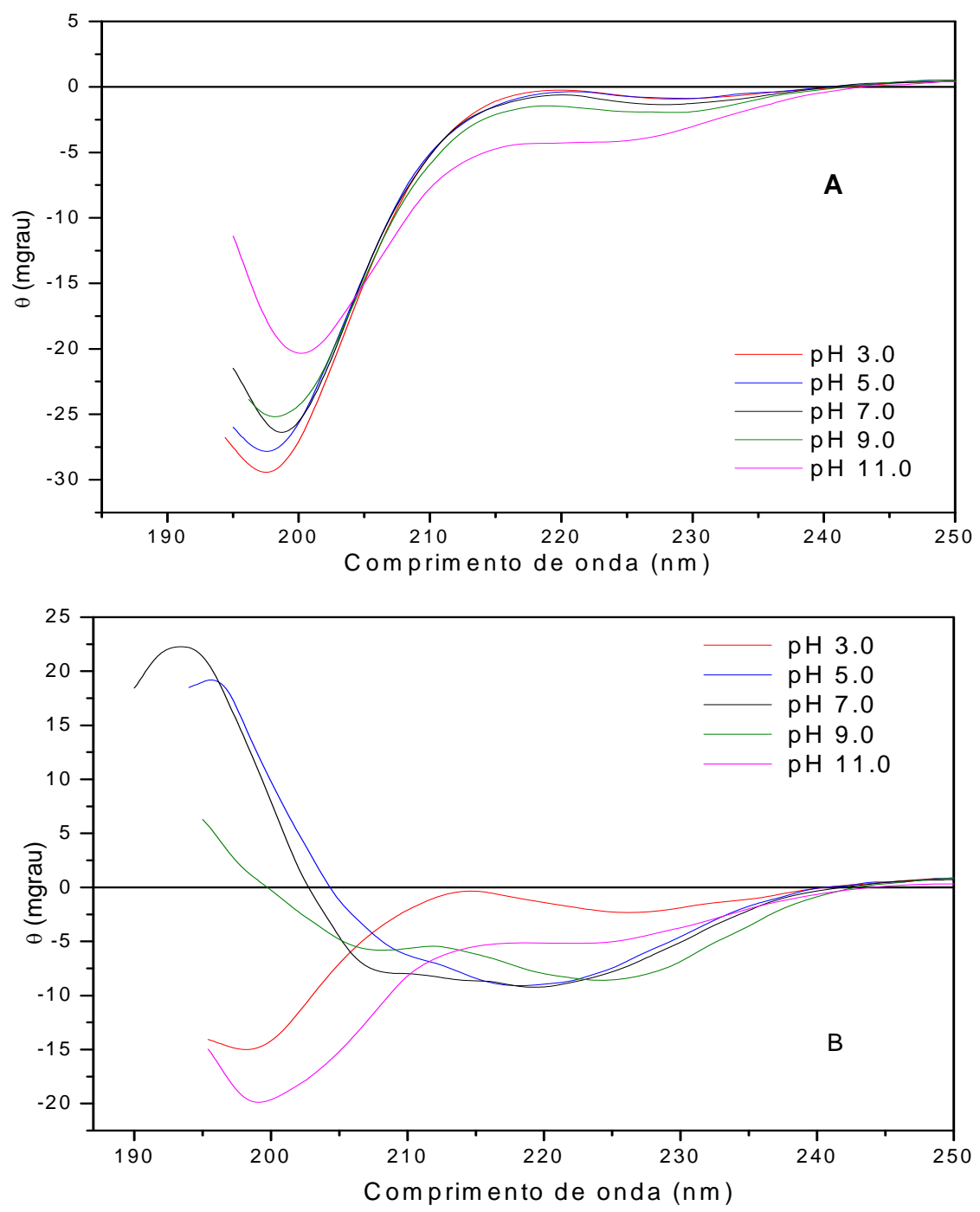

Figura 33 - Tratamento de pH em Pln149a antes e durante sua interação com LUVs de DPPG. (A) Pln149a $(0.2 \mathrm{mg} / \mathrm{mL})$ incubado em soluções com diferentes pHs, e (B) na presença de LUVs de DPPG nestas mesmas condições.

Da mesma forma, os espectros de $\mathrm{CD}$ da incubação do peptídeo em soluções com diferentes concentrações salinas na presença de vesículas negativamente carregadas mostram um forte efeito sobre a indução helicoidal do peptídeo. Inicialmente, conforme pode ser visto na Figura 34A, na ausência das vesículas fosfolipídicas, as diferentes concentrações de $\mathrm{NaCl}$ em todo o intervalo testado (de $50 \mathrm{mM}$ a $2 \mathrm{M}$ ) não alteraram o típico do espectro de peptideo em conformação randômica.

Nas soluções de menor força iônica $(0,50$ e $100 \mathrm{mM}$ de $\mathrm{NaCl})$ nota-se a ocorrência da indução helicoidal, com as bandas típicas desta estrutura, conforme já descrito anteriormente. No entanto, uma vez na presença de soluções contendo concentrações a partir das de $250 \mathrm{mM}$ de $\mathrm{NaCl}$, a interação deste AMP com as LUVs de DPPG foi afetada, de modo que a forma do espectro do peptídeo começou a ser alterada, com a diminuição da intensidade da banda em 
$222 \mathrm{~nm}$, e o deslocamento do mínimo de 208nm para $198 \mathrm{~nm}$ junto com o aumento da intensidade desta banda negativa.

Tal comportamento foi intensificado na presença de $500 \mathrm{mM}$ de $\mathrm{NaCl}$ na solução. E, por fim, para as soluções de mais alta força iônica (1 e 2 M de sal), o espectro de Pln149a se mostra inteiramente com a banda típica de estrutura randômica, sugerindo a ausência de interação entre o peptídeo e a vesícula nesta condição.

Este efeito pode ser explicado pela presença de grandes quantidades dos íons $\mathrm{Na}^{+} \mathrm{e} \mathrm{Cl}^{-}$ nas soluções mais concentradas. Estes íons atuam estabilizando as cargas negativas das cabeças polares do fosfolipídio e ao mesmo tempo as cargas positivas dos resíduos de Lys de Pln149a., e isto interações minimiza a atração eletrostática inicial entre essas duas espécies em solução.
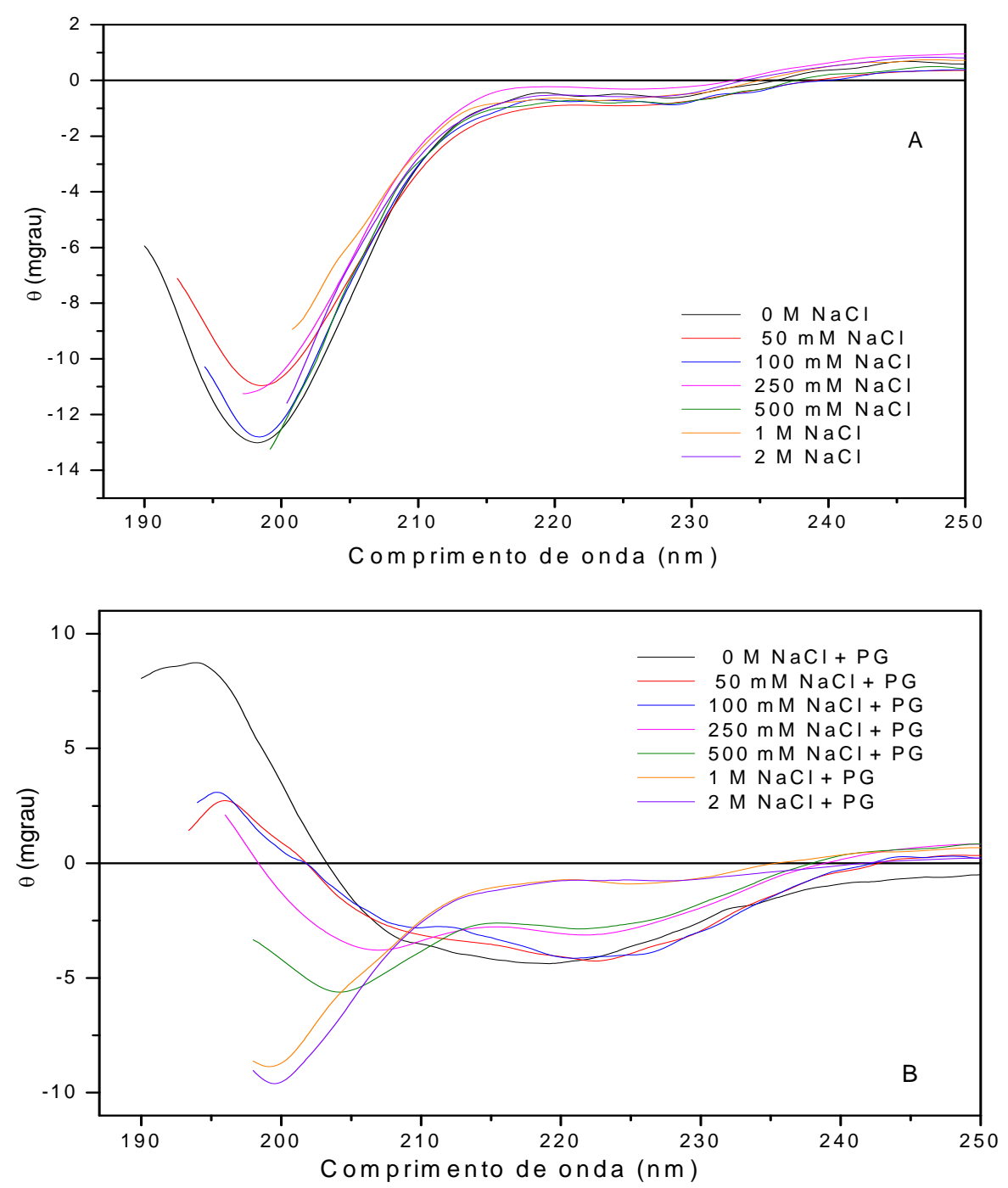

Figura 34 - Espectros de CD de PIn149a frente a variações de força iônica. (A) antes e (B) após sua interação com LUVs de DPPG. Os espectros foram tomados a $25^{\circ} \mathrm{C}$, com uma média de 16 varreduras, numa cubeta cilíndrica de caminho óptico de $1 \mathrm{~mm}$. Peptídeos $(0.15 \mathrm{mg} / \mathrm{mL})$ foram incubados as LUVs de DPPG. 


\subsubsection{Vesículas mistas}

Os espectros de CD de Pln149a nas vesículas de DPPC, DPPG e vesículas mistas de diferentes composições de DPPC/DPPG, mostrados na Figura 35, revelam que a indução de estrutura helicoidal na estrutura secundaria do peptídeo apresenta dependência com o aumento da densidade de cargas negativas (provenientes da cabeça polar do DPPG) na superfície dos lipossomos.

Além disso, pode-se notar que os espectros de Pln149a na presença de vesículas de DPPG/DPPC na razão 1:1 são muito semelhantes ao espectro da razão 1:3 e ao de DPPG puro, o que sugere que as contribuições eletrostáticas que favorecem a formação da hélice em Pln149a já são quase totalmente supridas na presença de $50 \%$ de cargas negativas no lipossomo, não havendo mudanças conformacionais significativas no peptídeo com o aumento da quantidade de DPPG no lipossomo após este valor.

Um comportamento semelhante foi verificado para o peptídeo da porção N-terminal de RGS4, no qual os espectros do peptídeo com lipossomos mistos contendo mais de $20 \%$ de DPPG é idêntico aqueles com maior quantidade e até 100\% do fosfolipídio negativo (101).

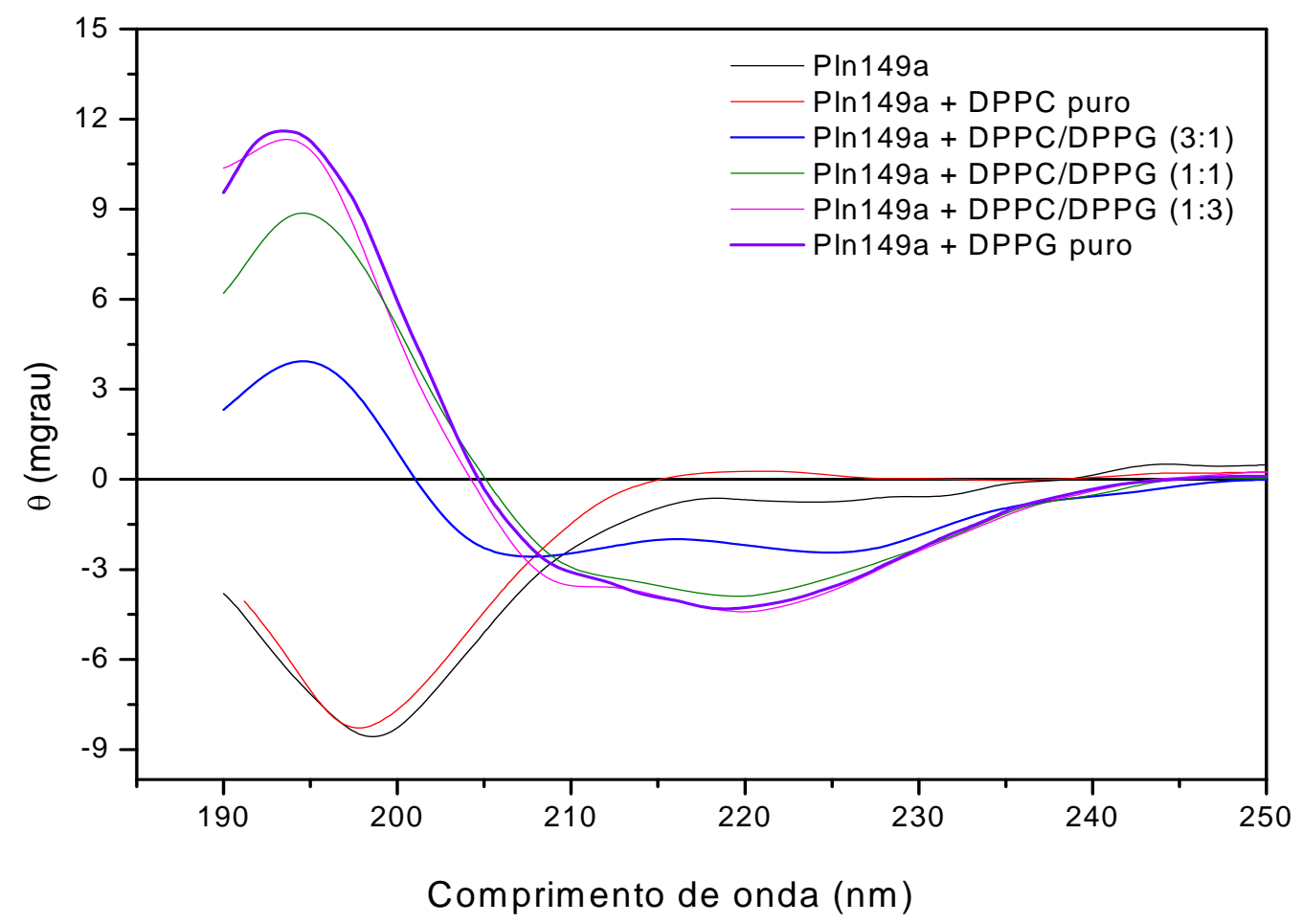

Figura 35 - Pln149a na presença de vesículas mistas de DPPC/DPPG em diferentes razões molares. O peptídeo $(0.2 \mathrm{mg} / \mathrm{mL})$ mostrou uma indução helicoidal proporcional à densidade de cargas negativas na superfície do lipossomo. 
Do mesmo modo que observado para o análogo Pln149a, os espectros de Pln149S também apresentam uma indução de estrutura helicoidal que se acentua conforme o aumento da composição de DPPG nas vesículas. Entretanto, o espectro de CD do peptídeo na presença de 50\% de DPPG, se assemelha mais ao espectro de CD em que Pln149S está na presença de $25 \%$ deste mesmo fosfolipídio. De modo que, se pode inferir que as contribuições eletrostáticas ainda não foram totalmente supridas para a interação de Pln149a com 50\% de fosfolipídios negativos na superfície do lipossomo, e há uma indução helicoidal mais significativa para porcentagens de DPPG acima de 50\% para este peptídeo, conforme pode ser observado na Figura 36.

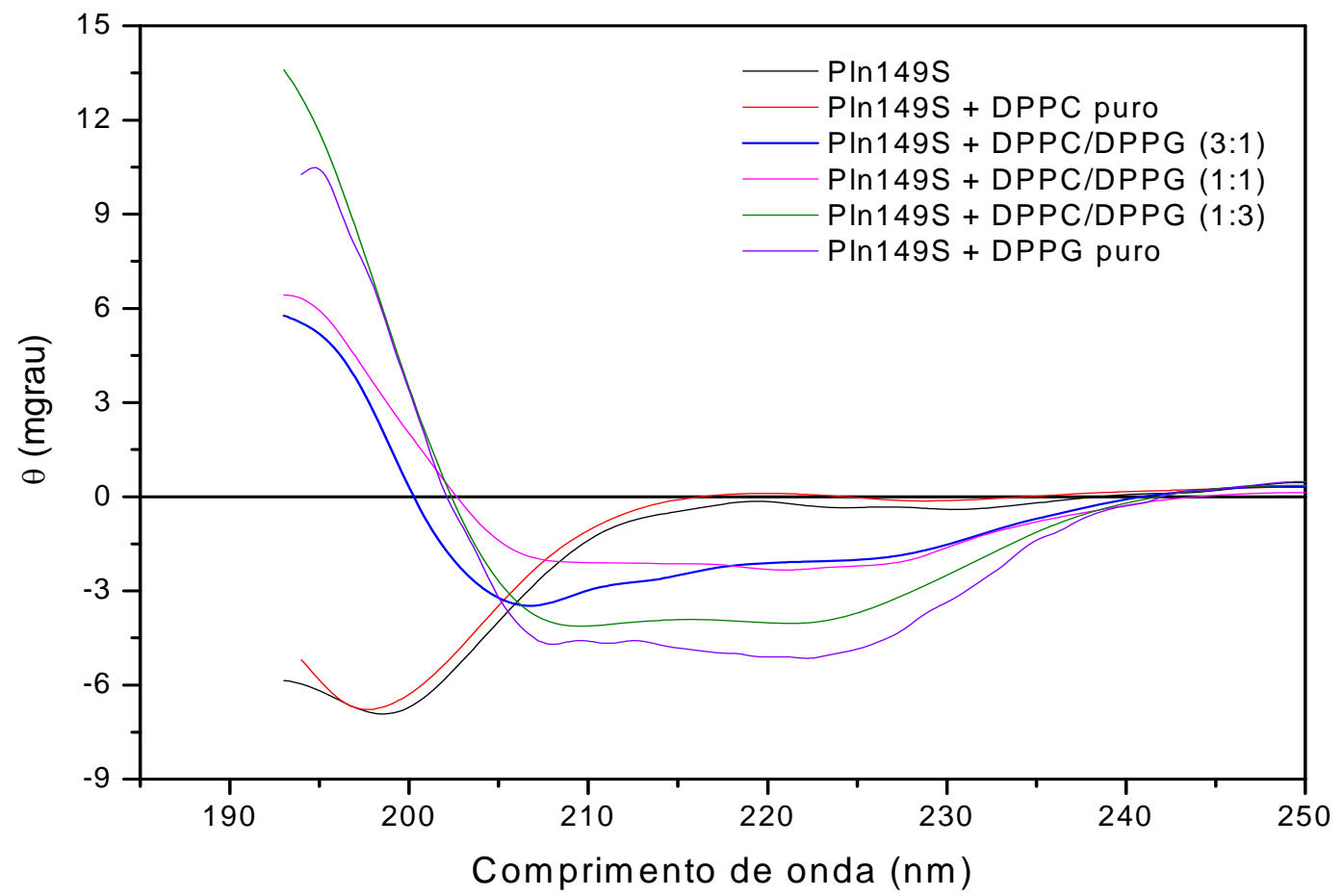

Figura 36 - Pln149S na presença de vesículas mistas de DPPC/DPPG em diferentes razões molares. Pln149S $(0.2 \mathrm{mg} / \mathrm{mL})$ também, mostrou uma indução helicoidal proporcional à densidade de cargas negativas no lipossomo, porém com menor intensidade do que observado para Pln149a.

O cálculo da fração helicoidal confirma as observações acima citadas, onde se pode notar a indução helicoidal na estrutura secundária dos peptídeos quando em presença de vesículas contendo fosfolipídios negativamente carregados, e o aumento e o aumento desta indução com o aumento da fração de DPPG na vesícula. Nota-se ainda, a sutil diferença no conteúdo de hélice em Pln149S e Pln149a, de acordo com a Tabela 9. 
Tabela 9 - Fração helicoidal de PIn149a e PIn149S com LUVs mistas de DPPG/DPPG

\begin{tabular}{rcc}
\hline & \multicolumn{2}{c}{ Fração de Hélice (\%) } \\
\hline Pln149a & Pln149S \\
\hline Solução aquosa & 1.0 & 0.8 \\
DPPC puro & 0.70 & 0.40 \\
DPPC/DPPG (3:1) & 7.9 & 6.7 \\
DPPC/DPPG (1:1) & 13 & 7.0 \\
DPPC/DPPG (1:3) & 14 & 12 \\
DPPG puro & 14 & 14 \\
\hline
\end{tabular}

Desta forma, do mesmo modo que observado para os peptídeos análogos do grupo II, onde a retirada do pentapeptídeo YSLQM do N-terminal da molécula afetou o conteúdo helicoidal induzido na cadeia polipeptídica, nota-se aqui, que a substituição de apenas um resíduo, no caso a Tyr da posição 1 por uma Ser, também está de acorda com esses resultados. Assim sendo, nota-se que além da que interação carga-carga que deve se estabelecer entre um AMP e a célula alvo durante sua atração eletrostática inicial, outro aspecto importante para a ação bactericida do AMP é o seu momento hidrofóbico, que define quão anfipático ele é. Essa propriedade depende das hidrofobicidades de cada um dos resíduos de aminoácidos na cadeia polipeptídica e é definida pela soma vetorial destas grandezas.

\subsubsection{Membranas de Leishmania}

A inibição do crescimento de células de Leishmania já foi reportada em alguns AMPs. Dois exemplos são as magaininas, peptídeos helicoidais expressos na pele de anfíbios, e as catelicidinas, que são $\beta$-peptídeos de mamíferos, ambos são capazes de promover a morte deste protozoário patogênico em concentrações fisiológicas via distintos mecanismos de ação.

A fim de monitorar a interação de Pln149a com vesículas constituídas pelos fosfolipídios que compõem a membrana plasmática de Leishmania, estudos de CD foram realizados e estão mostrados na Figura 37. Nela, podemos observar que, mesmo em contato com as vesículas constituídas com os fosfolipídios da membrana deste protozoário, Pln149a permanece com o perfil típico do espectro do peptídeo em solução aquosa, mostrando uma 
prevalência de conteúdo randômico em sua estrutura secundária. Tal ensaio sugere que Pln149a não foi atraído pelos componentes fosfolipídicos da membrana do protozoário, o que resulta na ausência de interação entre os dois. Desta forma, o AMP não deve promover a lise celular deste microrganismo.

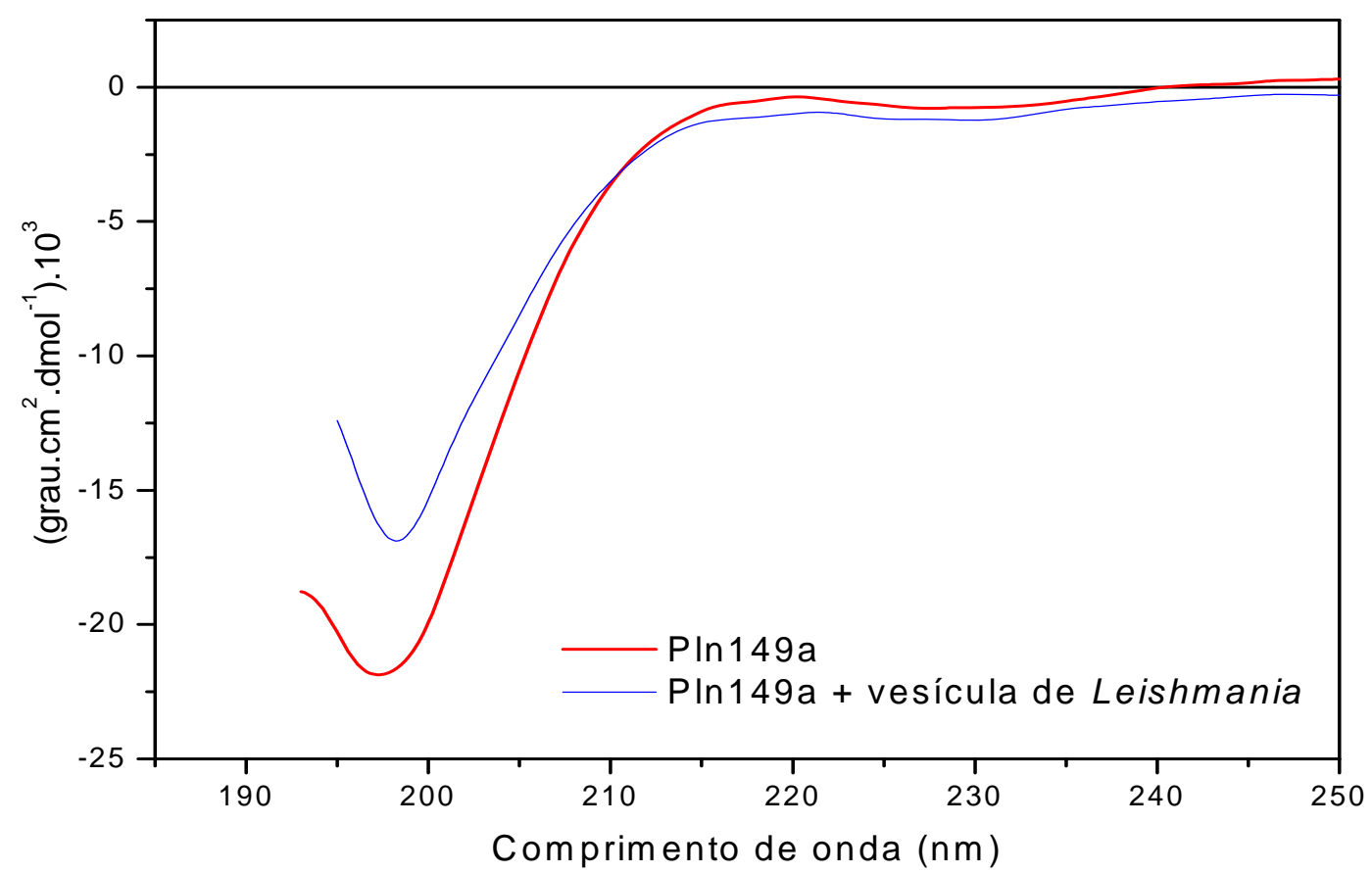

Figura 37 - Espectro de CD de PIn149a na presença de vesículas de Leishmania. O perfil do espectro de Pln149a não mostrou sofrer mudança conformacional devido o contato com tais vesículas.

\section{5.6 Dependência com a concentração de peptídeo}

A auto-associação de alguns AMPs pode ser estimulada com o aumento da concentração do peptídeo em solução. Estudos de CD com melitina e seus análogos mostraram que sua auto-associação é do modo concentração-dependente, no qual a intensidade das bandas em 222 e $208 \mathrm{~nm}$ aumentavam proporcionalmente a concentração do peptídeo em solução (13). Outro AMP, o AS-48, também apresenta associação influenciada pela concentração da bacteriocina, com a formação de oligômeros e dímeros em concentrações acima de $0.5 \mathrm{mg} / \mathrm{mL}$, mas que eram facilmente dissociados em monômeros com a diluição da solução (102).

A investigação da dependência da estrutura secundária de Pln149a com a concentração do peptídeo em solução aquosa, mostrada na Figura 38, revela que o conteúdo de estrutura 
secundária deste AMP não sofre nenhuma modificação em conseqüência do aumento da concentração do peptídeo em solução. Isto mostra que Pln149a não deva se auto-associar organizando em estruturas diméricas/oligoméricas a partir de uma concentração crítica.

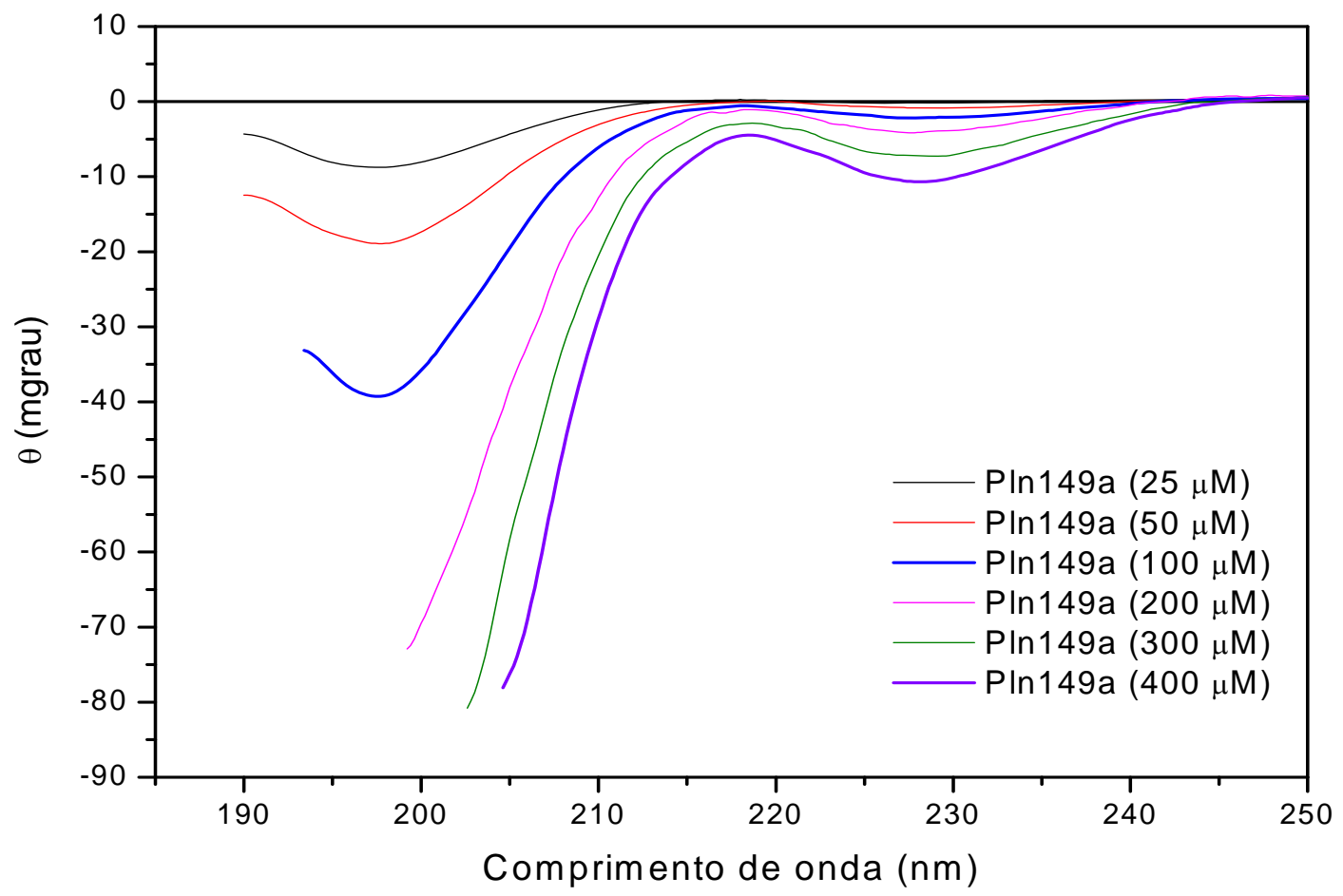

Figura 38 - Espectro de CD de Pln149a em diferentes concentrações. Os espectros de Pln149a nestas condições não mostram alteração conformacional em conseqüência do aumento da concentração do peptídeo.

Alguns investigadores sugerem que a auto-associação do peptídeo seja uma das diferenças notada logo nos primeiros passos dos mecanismos de ação já conhecidos para os AMPs permeabilizarem a membrana bacteriana através da formação de poros transmembrânicos. No modelo do poro barrel-stave, por exemplo, o passo inicial requer que o peptídeo monomérico interaja entre si e se associe em unidades oligoméricas para a formação do poro (25) antes da inserção nas membranas negativamente carregadas das bactérias. Desta forma, os oligômeros de AMPs atravessam a membrana celular do microrganismo, alinhando sua parte hidrofóbica em contato com às cadeias acil-graxas dos fosfolipídios, enquanto sua porção hidrofílica fica voltada para o lado interno do canal. Esta organização dos peptídeos forma canais que lembram um barril de tábuas, que dá o nome ao modelo: barrel-stave. O poro, então, atua como um canal de condutância que perturba o potencial transmembrânico e o gradiente de íons pelo vazamento dos componentes celulares internos, seguido da morte celular. 
O modelo do poro toroidal também compartilha características comuns com o modelo do barrel-stave. A diferença, no entanto, está no tipo do poro formado pelo AMP que, neste modelo, consiste na sua organização em uma monocamada peptídica que estabelece conexões entre os lipídeos internos e externos do canal.

Já no modelo do carpete, os peptídeos inicialmente se ligam a superfície externa da membrana celular do microrganismo e a cobrem como um carpete. A interação inicial com a membrana é eletrostaticamente dirigida. Na segunda etapa, após uma concentração limite na membrana ser atingida, os AMPs causam a permeação da membrana atuando como detergentes. Este modelo ainda sugere que a membrana se rompa em pedaços, o que conduz à lise da célula microbiana, de modo que os poros são formados por unidades micelares.

\section{6 Espectroscopia de fluorescência}

\subsubsection{Peptídeos em solução aquosa}

Os espectros de emissão de fluorescência intrínseca de Pln149a em água, mostrado na Figura 39, apresentam máximo de emissão de fluorescência $\left(\lambda_{\text {máx }}\right)$ centrado em $305 \mathrm{~nm}$. Vale lembrar que este peptídeo não contém resíduos de $W$ em sua seqüência, desta forma a excitação se deu em $275 \mathrm{~nm}$.

Os espectros de emissão de fluorescência dos peptídeos Pln149W e Pln149WS em solução aquosa quando excitados em 280 e $295 \mathrm{~nm}$ apresentam máximo de emissão centrado em $355 \mathrm{~nm}$, revelando que a micro vizinhança do resíduo aromático Trp está exposta ao solvente (em face a um ambiente polar), uma vez que este valor é esperado para a emissão deste resíduo livre em solução aquosa.

Do mesmo modo, os peptídeos análogos Pln149W(6-22), Ac-Pln149W(6-22) e Noctil$\mathrm{Pln} 149 \mathrm{~W}(6-22)$, que apresentam um resíduo de $\mathrm{W}$ em sua seqüência, mostram também um espectro com $\lambda_{\text {máx }}$ centrado em $355 \mathrm{~nm}$. Tal resultado concorda com os dados de CD que mostram que os peptídeos em solução aquosa se organizam em conformação randômica, de modo a deixar o resíduo de $\mathrm{W}$ em contato com o ambiente aquoso. 

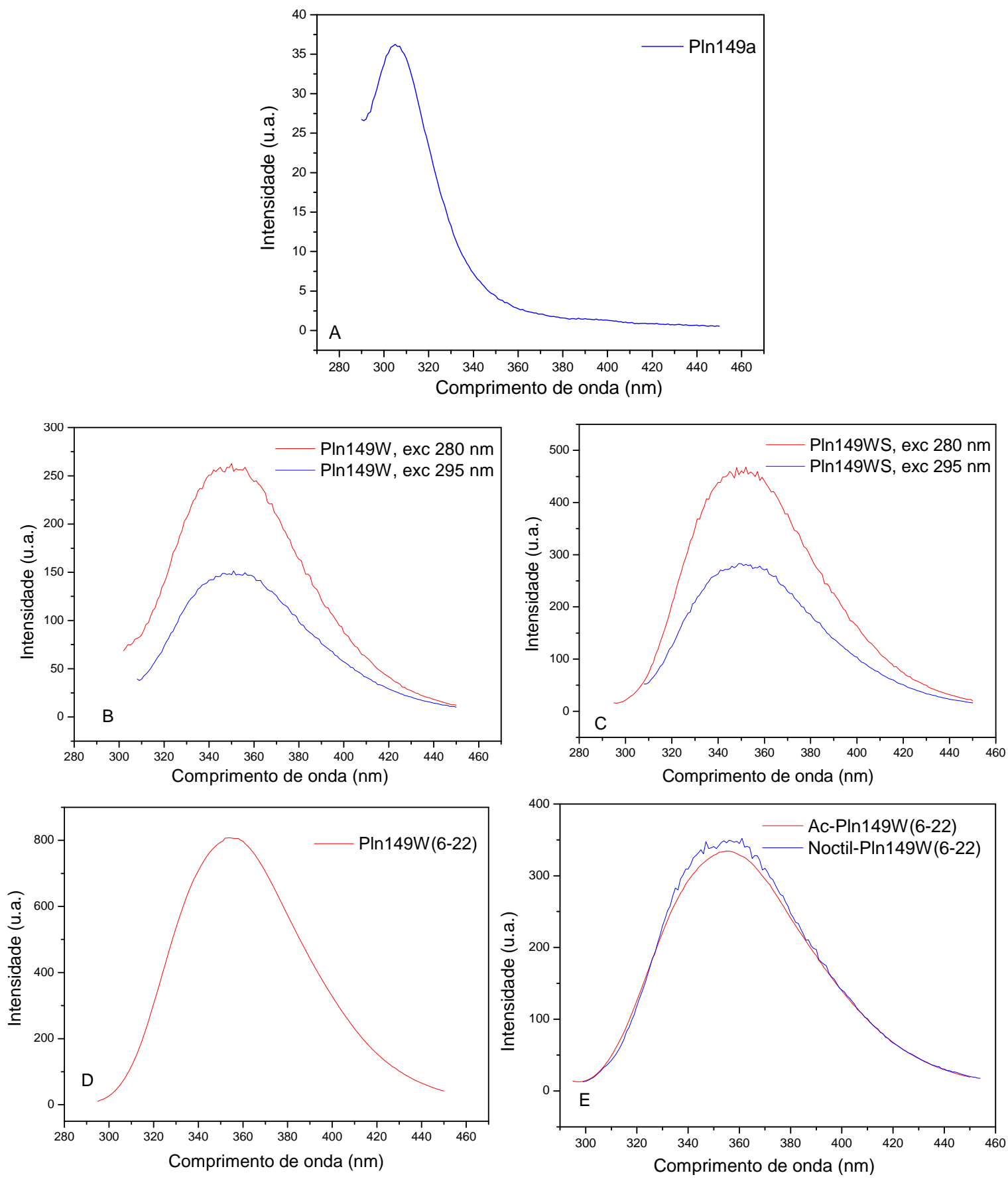

Figura 39 - Espectros de emissão de fluorescência de PIn149a e formas modificadas. (A) Pln149a foi excitada em $275 \mathrm{~nm}$ e os espectros foram tomados em água. (B) Pln149W, (C) Pln149WS (D) Pln149W(6-22), (E) Ac-Pln149W(6-22) e Noctil-Pln149(6-22) foram excitadas em $280 \mathrm{~nm}$. Os espectros foram tomados a $25^{\circ} \mathrm{C}$, com as amostras numa concentração de $0.07 \mathrm{mg} / \mathrm{mL}$. 


\subsubsection{Ionização do estado excitado da Tyr}

A Figura 40 mostra os espectros de emissão do resíduo de Tyr do peptídeo Pln149a, quando este foi incubado sempre no mesmo $\mathrm{pH}$ ( $\mathrm{pH}$ 7.4), mas sob concentrações crescentes do íon fosfato. Nela, não foi possível notar a emissão da forma tirosinato, mas nota-se o decréscimo da intensidade da emissão de fluorescência de Pln149a à medida em que a concentração do íon fosfato aumenta na solução.

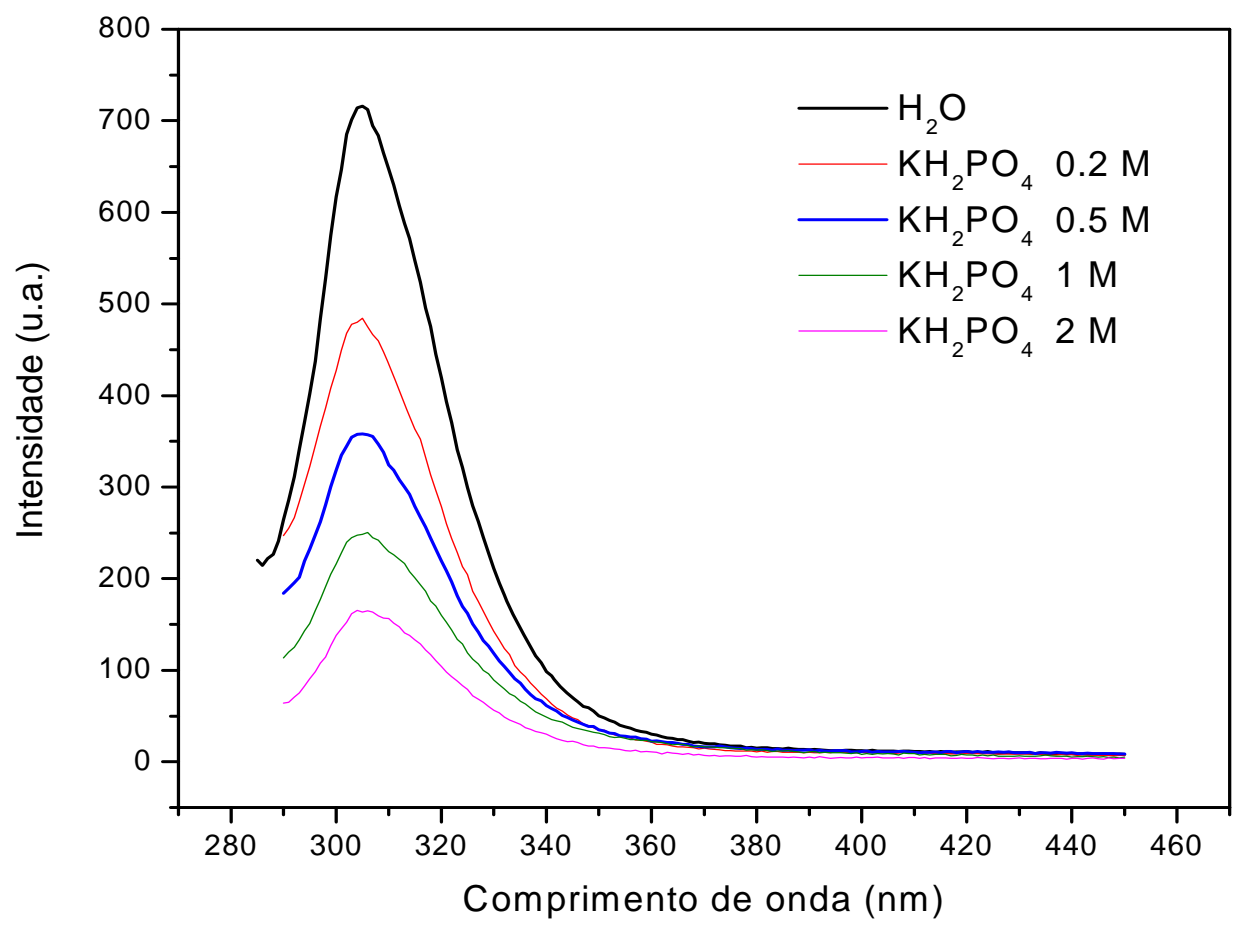

Figura 40 - Espectros de emissão de fluorescência de Pln149a em concentrações crescentes de $\mathrm{KH}_{2} \mathrm{PO}_{4}$. Os espectros de Pln149a foram tomados em cada condição, com excitação em $275 \mathrm{~nm}$.

Este decréscimo da intensidade ocorre pois o íon fosfato atua como uma base fraca que pode remover o próton do grupo fenólico ionizado da Tyr. Deste modo, o fosfato se comporta como um supressor colisional, e assim, quanto maior a fração de Pln149a ionizado, maior será a supressão, resultando numa menor intensidade de fluorescência.

A ionização do estado excitado ocorre porque o $\mathrm{pK}_{\mathrm{A}}$ da hidroxila do grupo fenólico decresce de 10.3 no estado fundamental para cerca de 4.0 no estado excitado. O ponto importante a se observar é que o grupo fenólico da Tyr pode se ionizar mesmo em $\mathrm{pH}$ neutros, deste modo, a emissão do tirosinato pode ser monitorada nestas condições, particularmente se o solvente contém aceitadores de prótons, ou seja, se contém determinadas concentrações de 
base que interaja com o estado excitado, tais como o íon acetato/fosfato, e se a Tyr está exposta para a fase aquosa.

\subsubsection{Presença de vesículas}

A interação de Pln149a com diferentes vesículas fosfolipídicas foi monitorada devido a presença do resíduo de Tyr neste peptídeo. No entanto, devido as características deste resíduo, nota-se pela Figura 41, que o posicionamento do $\lambda_{\text {máx }}$ para as diferentes vesículas permanece inalterado em torno de $305 \mathrm{~nm}$ na presença de todos os fosfolipídios investigados.

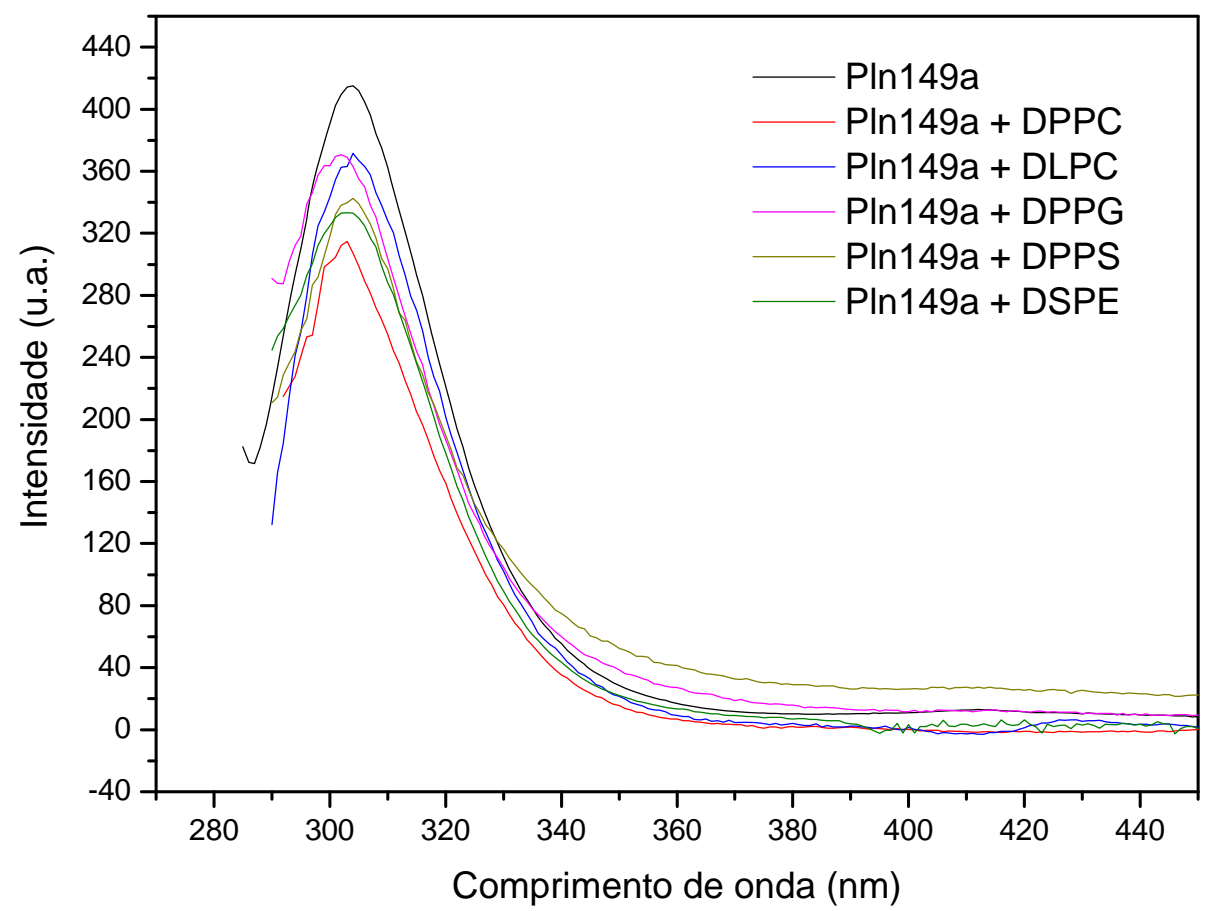

Figura 41 - Espectro de emissão de fluorescência da interação de Pln149a com LUVs. Os espectros foram tomados a $25^{\circ} \mathrm{C}$ com Pln149a $(0.07 \mathrm{mg} / \mathrm{mL})$ incubados com cada vesicula.

Os peptídeos análogos a Pln149a contendo o resíduo de $\mathrm{W}$ incorporados em sua sequencia foram monitorados quanto a emissão de fluorescência quando na presença de vesículas de DPPC e DPPG. Pela Figura 42, pode-se notar na presença das LUVs de DPPC não houve alteração do posicionamento do $\lambda_{\text {máx }}$ do espectro dos peptídeos. No entanto, durante a interação com as LUVs de DPPG, nota-se o deslocamento para o azul (blue shift) do 
$\lambda_{\text {máx }}$, indicando que a microvizinhança do resíduo de $\mathrm{W}$ foi alojada num ambiente mais apolar, concordando mais uma vez com os dados de CD, que mostram a indução helicoidal no peptídeo. De fato, o interior de uma hélice representa um meio que a cadeia lateral do resíduo aromático pode ocupar e se proteger de interações com a solução.
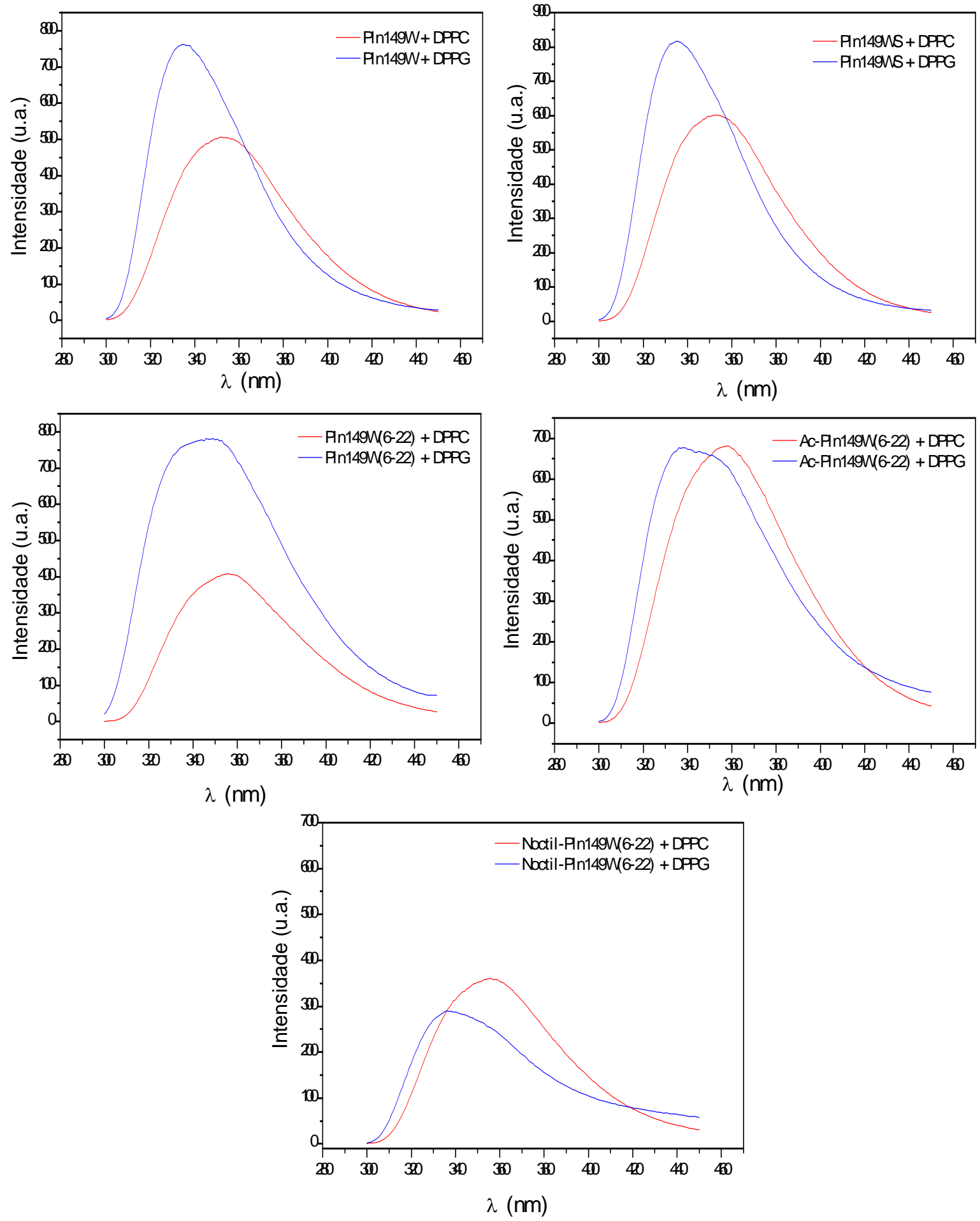

Figura 42 - Espectros de fluorescência da interação dos peptídeos análogos a Pln149a com LUVs de DPPC e DPPG. Os espectros foram tomados a $25{ }^{\circ} \mathrm{C}$ com os peptídeos na presença de cada uma destas vesículas. 


\subsubsection{Ensaios de Leakage}

Nesse ensaio, se avaliou a capacidade da molécula de DPX de suprimir a fluorescência do ANTS pelo processo de transferência colisional. As duas moléculas foram encapsuladas juntas no interior de lipossomos, numa concentração relativamente alta. Nestas condições, o sinal de ANTS registrado no fluorímetro $\left(F_{0}\right)$ foi mínimo ( $\sim 6$ u.a) devido à forte supressão sofrida pela pelo DPX, conforme visto na Figura 43.

A adição de determinadas quantidades de Pln149a favoreceu a permeabilização dos lipossomos, resultando na saída dos dois compostos do interior das vesículas, de forma que ambos se separassem na solução externa. Quando se diluíram no meio, ocorreu o desaparecimento da supressão de DPX sobre o ANTS, resultando no aumento do sinal de fluorescência, que se acentuou com o aumento da quantidade de peptídeo adicionada.

Ao adicionarmos o detergente Triton X-100, se dá a ruptura máxima dos lipossomos, com o vazamento total dos conteúdos internos dos lipossomos. Desta forma, temos um aumento significativo da quantidade de ANTS livre, que nos dá o sinal máximo de fluorescência $\left(F_{100}\right)$, por volta de 32 u.a.

Na Figura 43 A e B, estão mostradas as porcentagens de liberação dos conteúdos vesiculares em lipossomos de DPPG (leakage), calculadas segundo a equação (3) descrita na seção materiais e métodos, para a ação do peptídeo Pln149a e Pln149S, respectivamente. Nela, observa-se a liberação de pequenas quantidades da sondas já a partir da concentração de $1 \mu \mathrm{M}$ de Pln149a, enquanto para Pln149S, apenas com $2 \mu \mathrm{M}$ que se inicia a permeabilização dos lipossomos. Nota-se ainda, um aumento da porcentagem de liberação de ANS em comportamento quase linear até a concentração de $4 \mu \mathrm{M}$. Para concentrações mais altas, um significativo aumento no sinal de fluorescência é observado tanto para Pln149a como Pln149S. Concentrações mais elevadas dos dois peptídeos já atingem valores de $100 \%$ de leakage nos primeiros instantes de incubação com os lipossomos. 

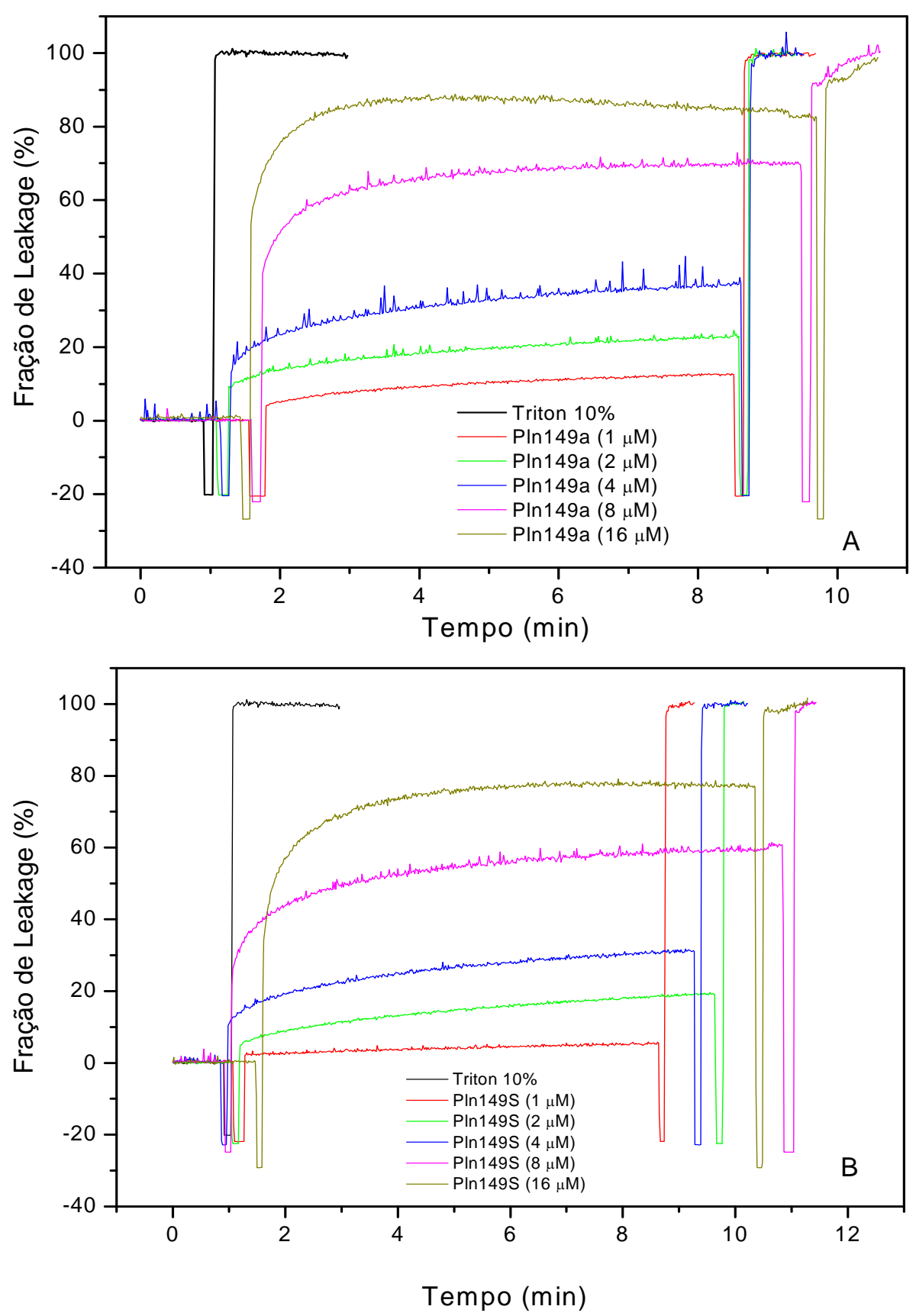

Figura 43 - Liberação dos conteúdos vesiculares em lipossomos de DPPG. A adição de diferentes quantidades de Pln149a (A) e Pln149S (B) perturba a integridade dos lipossomos de DPPG.

A curva de liberação dos conteúdos vesiculares dos dois peptídeos, após 500s de interação com os lipossomos, está apresentada na Figura 44. Nela, é possível comparar a ação dos dois peptídeos sobre as vesículas de DPPG, e observar a sutil diferença nas atividades entre esses peptídeos, na qual se vê que Pln149a teve maior efeito lítico sobre as LUVs de DPPG do que Pln149S, tal efeito se acentua a partir de concentrações acima de $4 \mu \mathrm{M}$. Esta diferença pode ser comparada, e está de acordo com àquela observada nos experimentos de 
CD, onde se observa maiores mudanças conformacionais na estrutura de Pln149a após interagir com DPPG.

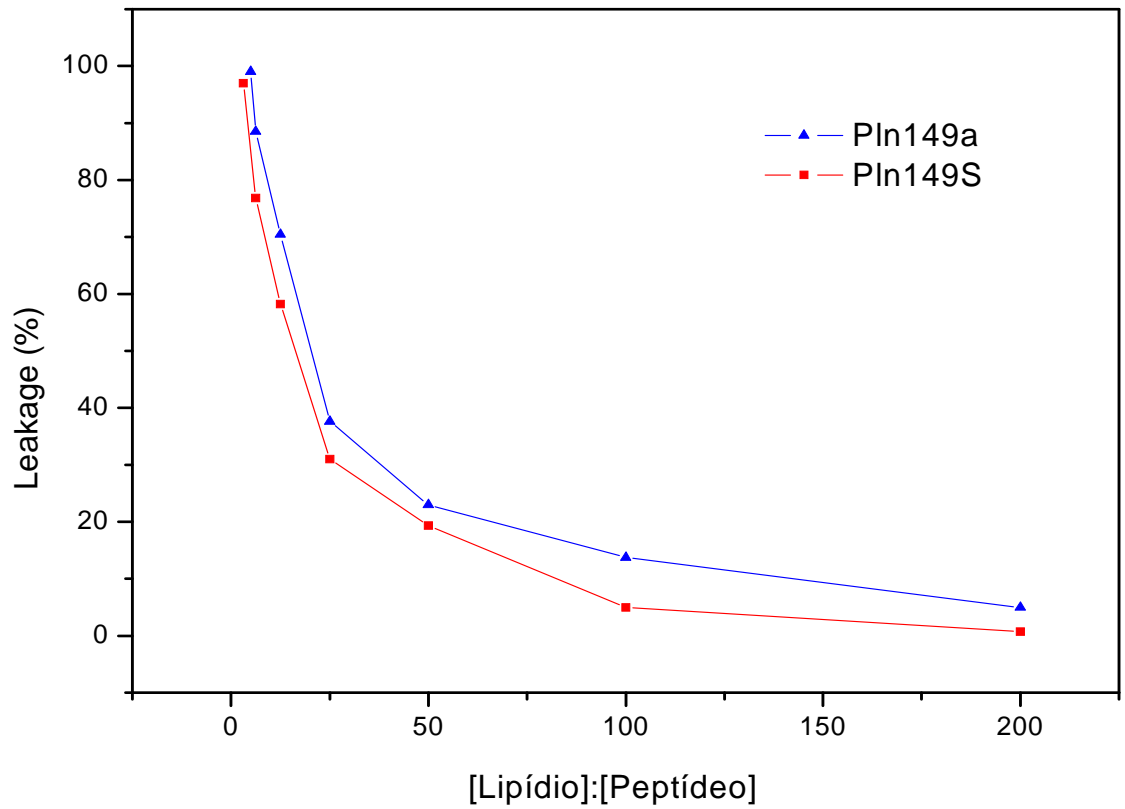

Figura 44: Comparação da fração de ANS liberado pelos lipossomos de DPPG pela ação de PIn149a e PIn149S. Uma sutil diferença no conteúdo do vazamento provocado pela adição dos dois peptídeos pode ser notada.

A fim de comparar o efeito de permeabilização de lipossomos, mas de também levar em conta o grau de fluidez/empacotamento da membrana, o mesmo experimento foi realizado com os peptídeos Pln149a e Pln149S para vesículas fosfolipídicas de POPG (palmitoilleoilfosfatidilglicerol). Tal fosfolipídio, além de apresentar uma cabeça polar negativamente carregada, que é essencial para a interação dos peptídeos, apresenta um dos seus ácidos graxos com uma insaturação na cadeia alifática, o que resulta numa temperatura de transição de fase de gel para líquido-cristalino por volta de $20^{\circ} \mathrm{C}$, valor que está muito mais abaixo do que o esperado para a transição do DPPG (por volta de $40^{\circ} \mathrm{C}$ ).

Desta maneira, como observado na Figura 33, a quantidades de peptídeo necessárias para promover a rupturas destes lipossomos foi bem menor do que para as vesículas de DPPG, chegando a obter $100 \%$ de leakage para uma concentração de $1.5 \mu \mathrm{M}$ de Pln149a. A maior eficácia dos peptídeos frente a estes lipossomos pode ser explicada em termos das forças não covalentes estabelecidas entre os fosfolipídios que formam a estrutura de vesículas. Devido ao menor grau de empacotamento das moléculas de POPG, as interações de Van de Waals que se estabelecem entre elas são menos favorecidas, aumentando, portanto, o grau de fluidez da membrana, uma vez que uma menor quantidade de energia será necessária para que 
se estabeleça uma transição de fase ou para desestruturar as mono/bicamadas formadas por elas. Já nas estruturas formadas por fosfolipídios saturados como o DPPG, temos um melhor empacotamento das cadeias acil graxas, resultando num maior efeito destas interações fracas, que aumentam a rigidez da bicamada.

Ainda na Figura 45, estão as curvas do leakage de Pln149a (A) e Pln149S (B), no qual o maior efeito lítico de Pln149a também é notado quando comparado como efeito de Pln149S.
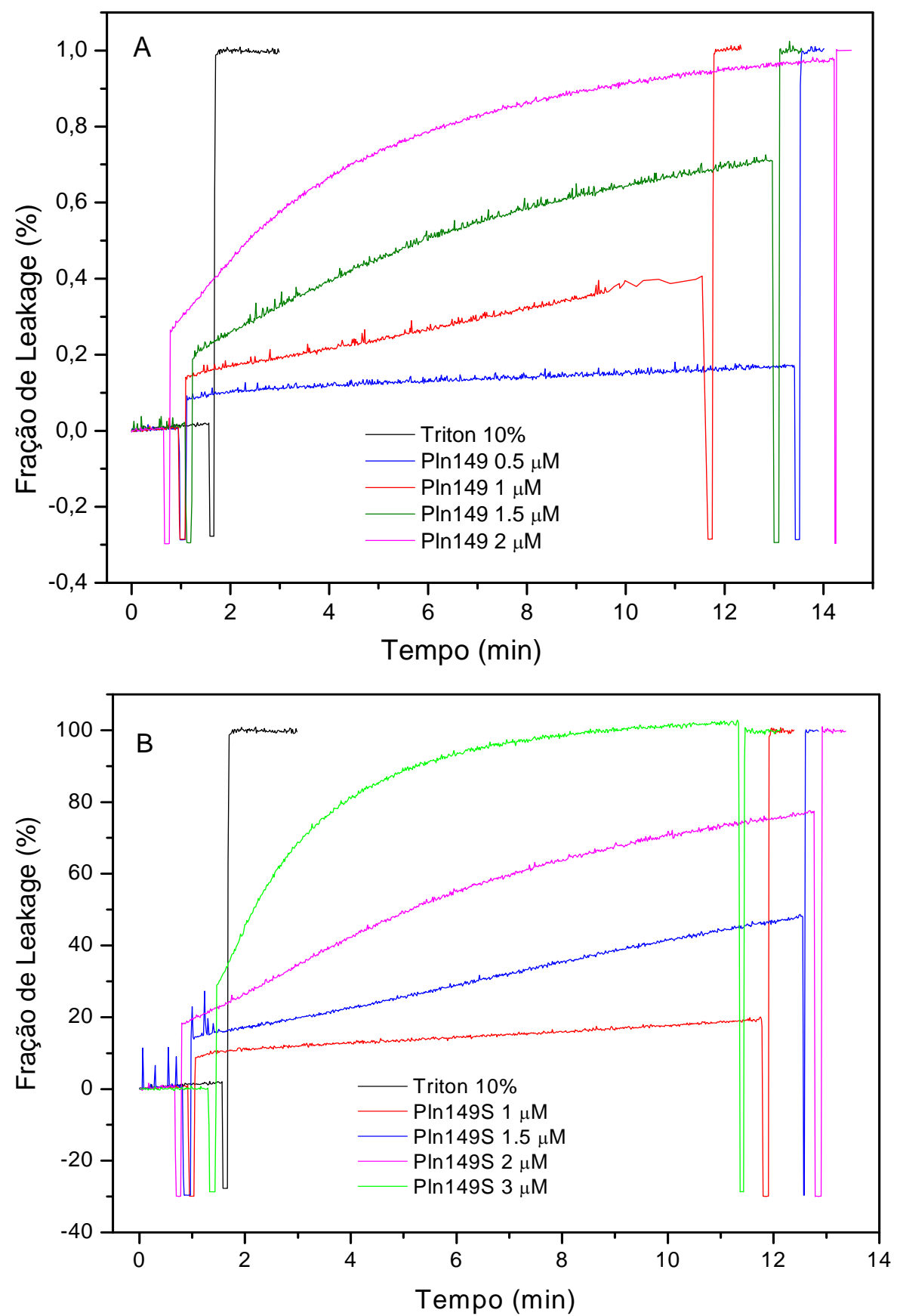

Figura 45 - Liberação dos conteúdos vesiculares em lipossomos de POPG. A adição de de Pln149a (A) e Pln149S (B) perturbam a integridade dos lipossomos de POPG em pequenas concentrações do peptídeo. 
As curvas de liberação de ANS para vesículas de POPG pela ação de Pln149a e Pln149S após $500 \mathrm{~s}$ de incubação com os peptídeos também foram plotadas, e estão mostrados na Figura 46.

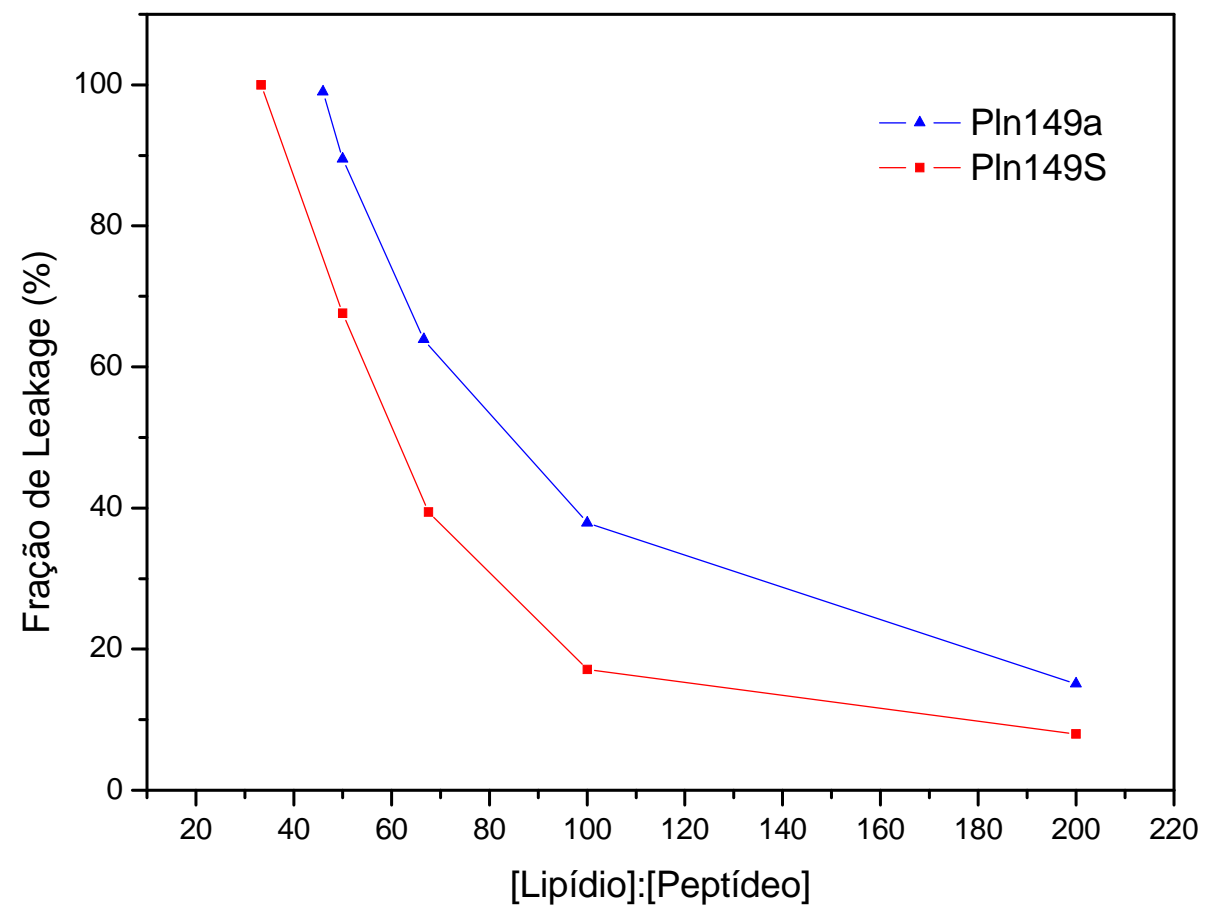

Figura 46 - Fração de ANS liberado pelos lipossomos de POPG pela ação dos peptídeos. A diferença no conteúdo do vazamento provocado pela adição dos dois peptídeos também é evidenciada nestes lipossomos.

Uma alíquota de vesículas mistas de DPPC/DPPG (1:1) também foi preparada contendo a sonda encapsulada em seu interior a fim de se comparar a liberação dos conteúdos vesiculares de Pln149a nesta condição com o vazamento promovido nas vesículas de DPPG puro. Neste experimento, mostrado na Figura 47, não foi detectado um vazamento significativo da sonda para concentrações inferiores a $4 \mu \mathrm{M}$ de Pln149a. O início do vazamento só foi promovido a partir de $8 \mu \mathrm{M}$ do peptídeo, com um baixo valor de leakage, por volta de $9 \%$. Nota-se ainda que, a partir da concentração de $16 \mu \mathrm{M}$ não houve um aumento significativo da quantidade de sonda liberada à medida que se aumentou a concentração do peptídeo, atingindo um valor de leakage de $20 \%$, bem inferior ao comparado com o da adição de Triton X-100. 


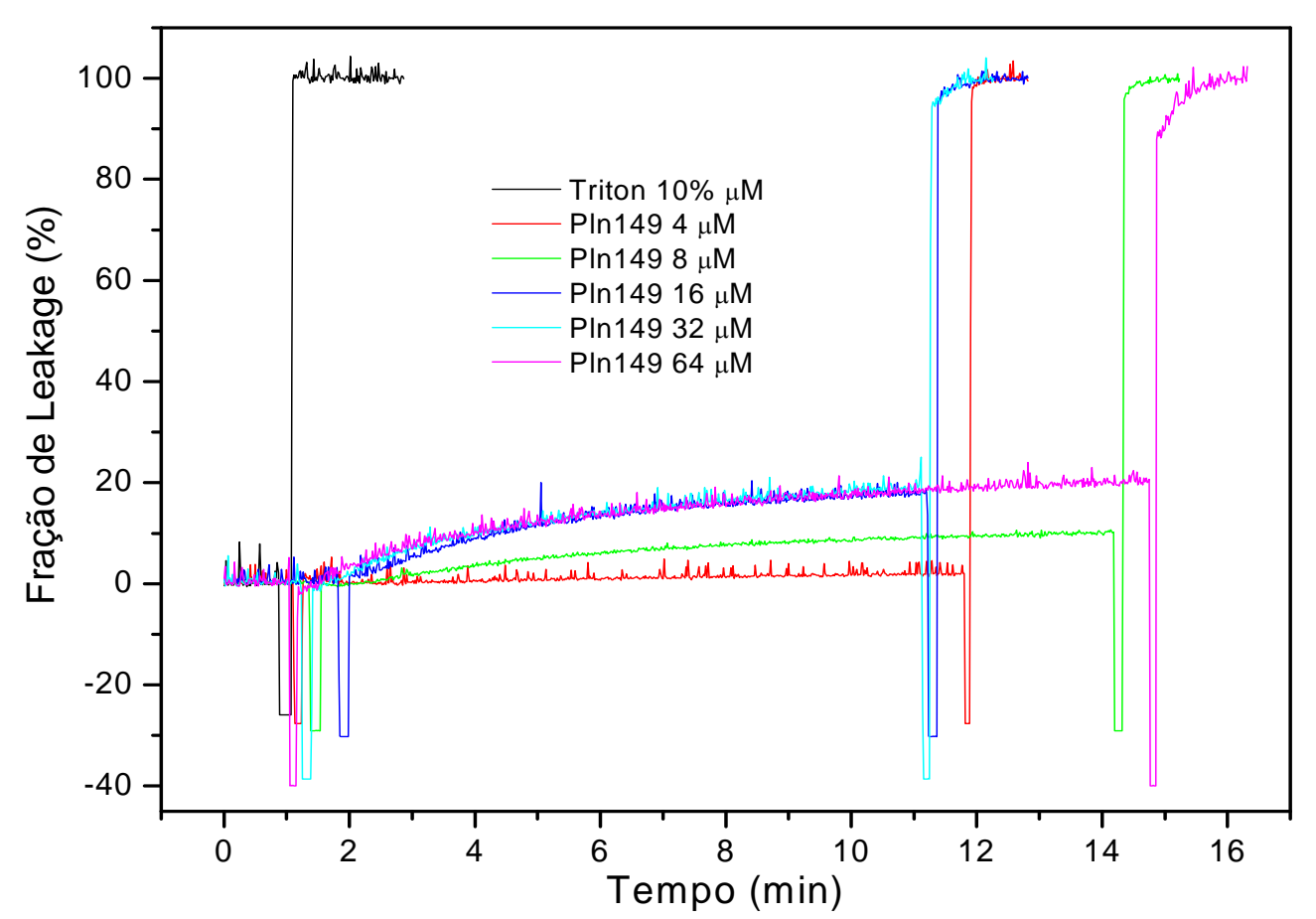

Figura 47 - Liberação dos conteúdos vesiculares em vesículas mistas de DPPC/DPPG (1:1) pela ação de Pln149a.

Essa diferença no efeito perante as vesículas de DPPG puro comparado com o das vesículas mistas, onde temos, por exemplo, em $8 \mu \mathrm{M}$ do peptídeo, um vazamento de $70 \%$ para os lipossomos de DPPG contra apenas 9\% nas vesículas mistas, confirma mais uma vez a especificidade do peptídeo para interagir com fosfolipídios negativamente carregados, promovendo a desorganização de bicamadas formada por essas moléculas. As porcentagens de leakage nessas ultimas vesículas, estão mostrados na Figura 48. 


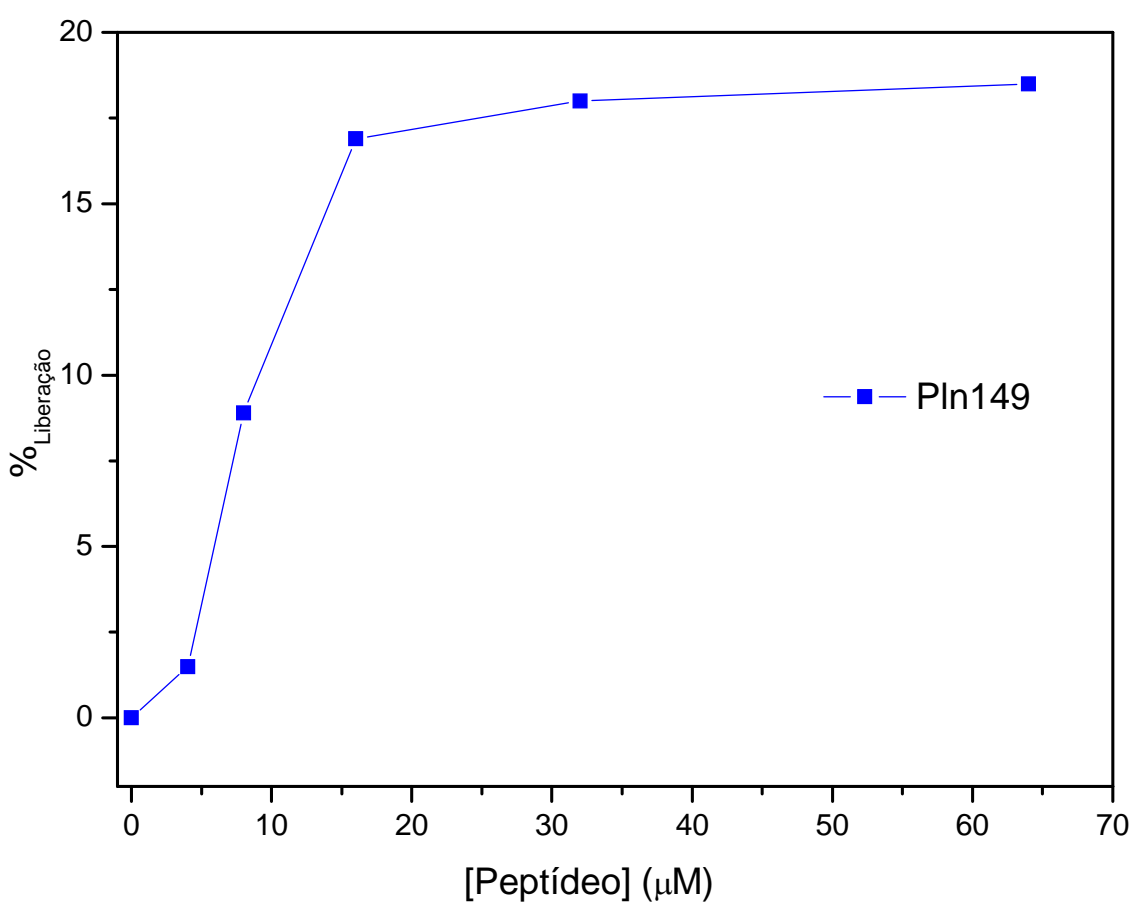

Figura 48 - Leakage em lipossomos de DPPG/DPPC (1:1) pela ação de Pln149a.

\subsubsection{Titulação do triptofano}

A ligação dos peptídeos análogos a Plantaricina149 às vesículas fosfolipídicas foi investigada por experimentos de emissão de fluorescência intrínseca do resíduo de Trp incorporado na seqüência peptídica de Pln149W e Pln149WS. Tal ensaio foi realizando monitorando o rendimento quântico e o comprimento de emissão máxima destes peptídeos na ausência e na presença de diferentes razões lipídio/peptídeo.

Pela Figura 49, pode-se observar que os dois peptídeos apresentam $\lambda_{\max }$ centrado em $350 \mathrm{~nm}$ quando em tampão Hepes, indicando, a alta exposição do Trp ao ambiente aquoso. No entanto, um blue shift por volta de $10 \mathrm{~nm}$ foi observado no espectro de emissão de ambos os peptídeos quando em contato com as LUVs de DPPG, em conseqüência das interações eletrostáticas que se estabelecem entre os peptídeos e os fosfolipídios, que faz com que o microambiente do resíduo de $\mathrm{W}$ fique em face de um ambiente menos polar (mais hidrofóbico). Este deslocamento é observado em todas as razões peptídeo/lipídio testadas, que passam a apresentar $\lambda_{\max }$ centrado em $340 \mathrm{~nm}$. 

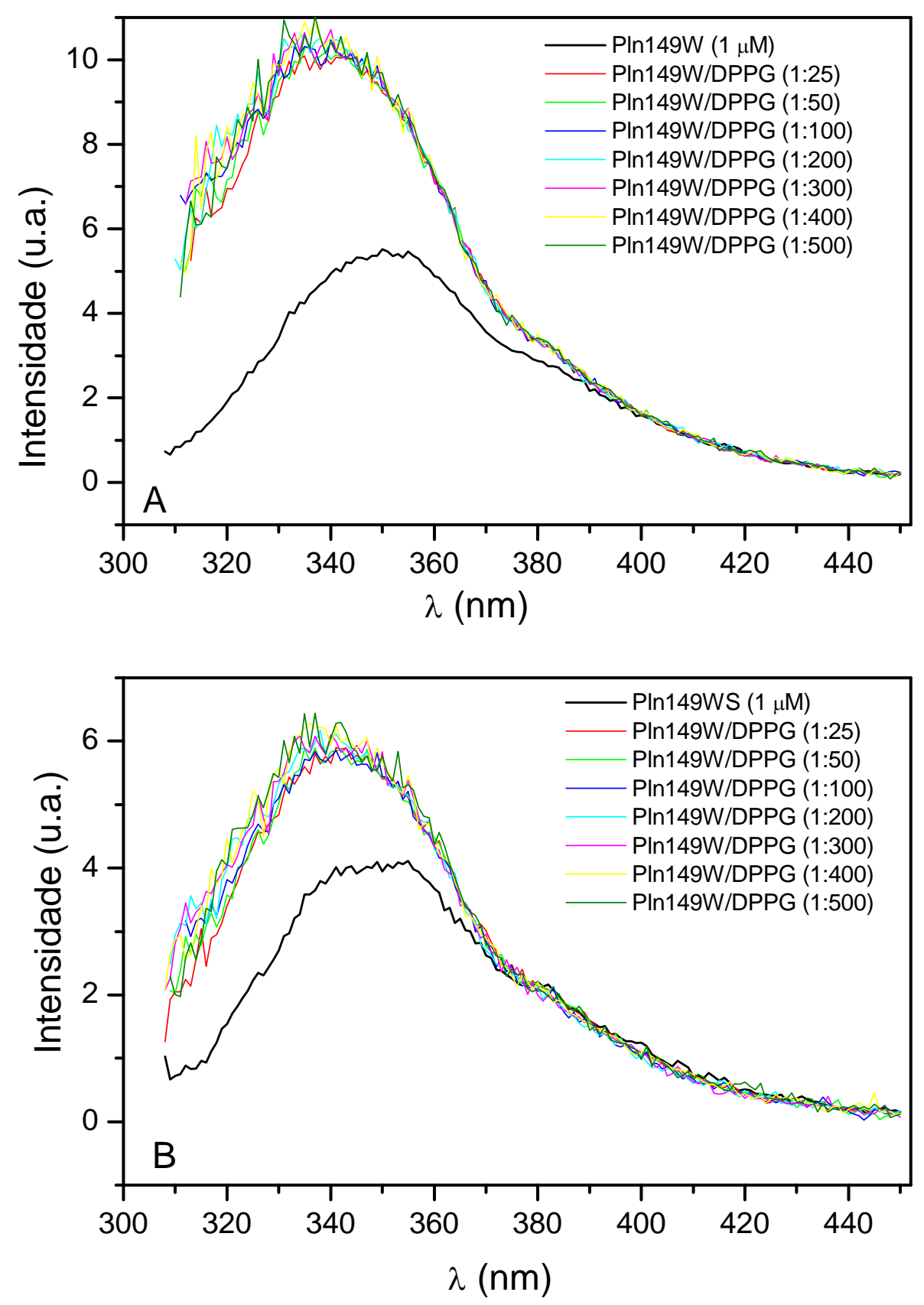

Figura 49 - Espectros de fluorescência de PIn149W (A) e PIn149WS (B) na ausência e na presença de LUVs de DPPG. Um deslocamento para o azul (blue shift) de $10 \mathrm{~nm}$ é observado.

Os dados das titulações de Pln149W e Pln149WS em $350 \mathrm{~nm}$ foram usados para construir as curvas da Figura 50 (A e B, respectivamente), que ajustadas com uma equação hiperbólica nos forneceram os valores das constantes de dissociação $\left(\mathrm{K}_{\mathrm{D}}\right)$ de $57.1 \mathrm{nM}$ para Pln149W e 146 nM para Pln149WS quando ligadas às vesículas de DPPG.

Os valores destas constantes na ordem de nanomolares refletem alta afinidade de Pln149a e seus peptídeos análogos para se ligar a essas vesículas negativas. Além disso, a diferença nos valores $K_{D}$ (quase três vezes maior para Pln149WS) mostra outra vez se que a 
interação do peptídeo contendo a Tyr no N-terminal do peptídeo (Pln149W) é mais intensa que a do peptídeo substituído por Ser (Pln149WS).
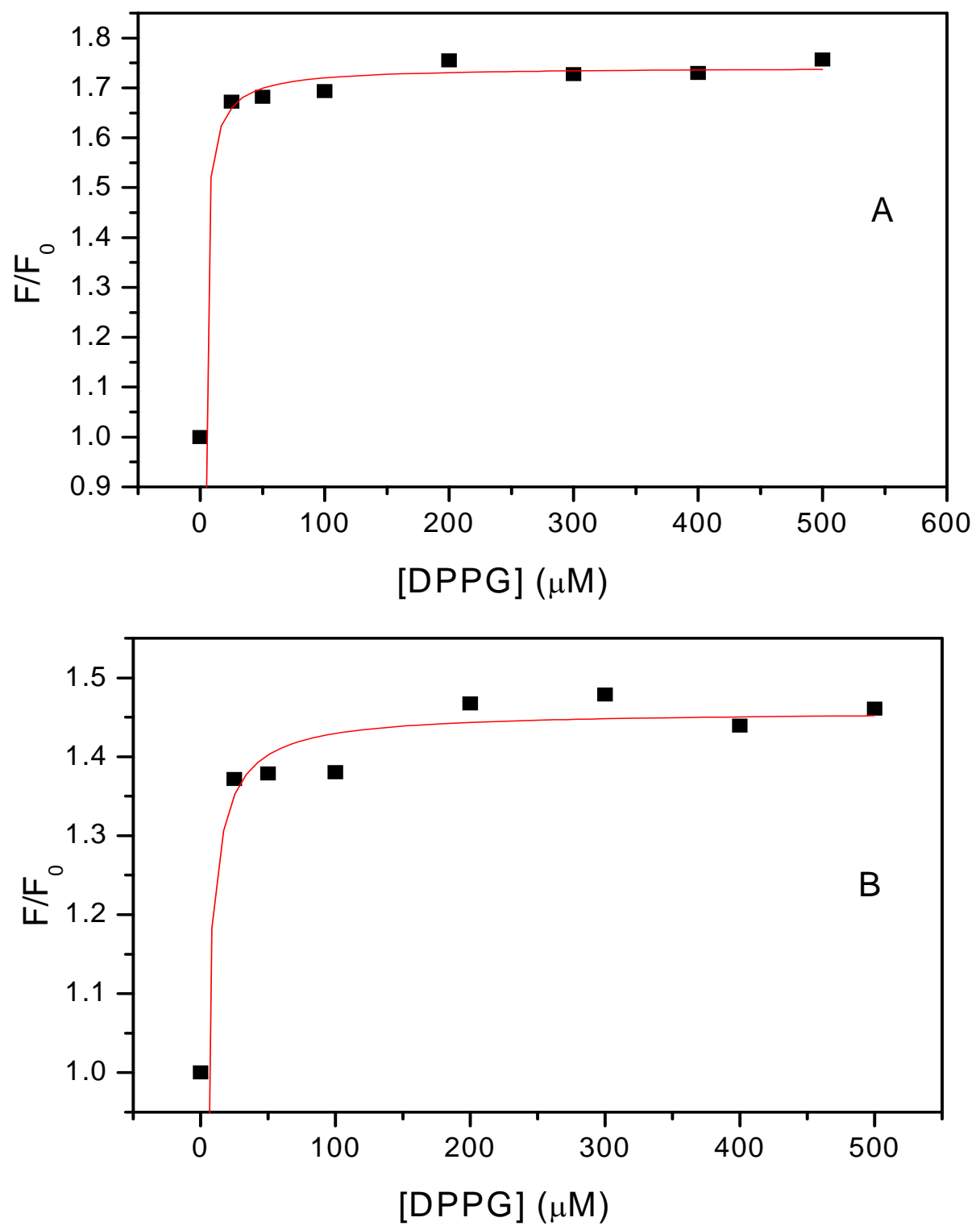

Figura 50 - Ajuste experimental das emissões dos peptídeos em 350 nm. (A) Pln149W e (B) Pln149WS, foram titulados com vesículas de DPPG.

Tais resultados, nos sugerem a importância entálpica não somente da formação de ligações de hidrogênio e/ou ligações iônicas entre o peptídeo e as vesículas, mas também no papel dos resíduos mais apolares que contribuem com outros tipos de ligações não covalentes, tais como as de van der Waals durante a interações peptídeo-lipídio.

As interações que regem a ligação de um peptídeo a uma vesícula é um processo de adsorção física que pode ser dividido em pelo menos três etapas moleculares (103). Tal como visto para a interação de $\mathrm{Pln} 149 \mathrm{a}$, a primeira etapa do processo é uma atração eletrostática do 
peptídeo catiônico para a superfície da vesícula. Na segunda etapa, Pln149a é adsorvido na região dos grupos polares. Essa penetração de Pln149a parece ser dirigida entalpicamente por forças de van der Waals. Alem disso, forças entrópicas, como o efeito hidrofóbico, também contribuem energeticamente para esta penetração.

Se observarmos a estrutura primaria de Plantaricina 149, nota-se que a região Nterminal da molécula é a mais apolar, de acordo com o diagrama de hidrofilicidade da molécula (Figura 51). É de se esperar, portanto, que as maiores contribuições tanto das forcas de van der Waals como a do efeito hidrofóbico venham desta região da molécula. Deste modo, a substituição do resíduo de Tyr por um resíduo de Ser no N-terminal do peptídeo (como ocorre em Pln149WS), faz com que o caráter apolar desta região seja reduzido, tornando mais fraca as contribuições energéticas vindas por interações hidrofóbicas. Isso torna menos eficaz o processo de penetração/adsorção do peptídeo nas vesículas lipídicas.

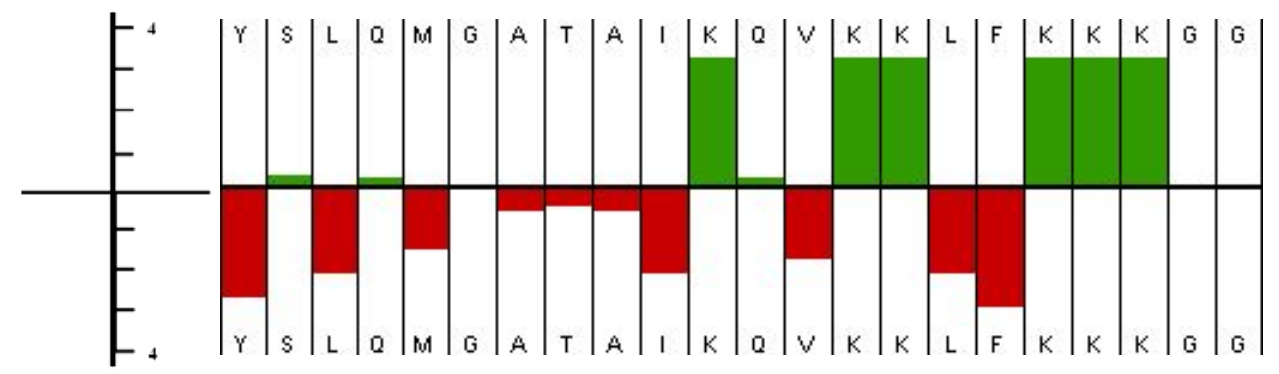

Figura 51 - Diagrama de Hidrofilicidade de PIn149a. Os resíduos hidrofílicos estão mostrados em verde, e resíduos hidrofóbicos, em vermelho. A altura das colunas reflete o quão hidrofílico/hidrofóbico são os resíduos. Figura gerada no site Peptide Property Calculator Innovagen.

Na terceira etapa acontece a inserção de Pln149a na vesícula, que é acompanhada por uma mudança conformacional do peptídeo, onde uma hélice anfipática é induzida na região dos resíduos de Lys. Essa transição para a estrutura helicoidal foi vista claramente nos experimentos de CD.

Através do cálculo da fração de peptídeo ligada à superfície dos lipossomos também se pode observar a alta afinidade destes peptídeos pelos fosfolipídios negativos, uma vez que logo na primeira titulação dos lipossomos, houve uma fração por volta de $80 \%$ de peptídeos ligados para as vesículas de DPPG. A quantidade de peptídeo ligado aos lipossomos aumenta de acordo com o aumento da quantidade de lipídios na solução até atingir valores por volta de 99\% do peptídeo ligado. Os valores obtidos para todas as razões ensaiadas para as vesículas de DPPG estão na Tabela 10. 
Tabela 10: Fração de peptídeo ligada à superfície dos lipossomos de DPPG

\begin{tabular}{ccc}
\hline Razão peptídeo/lipídio & Pln149W (\%) & Pln149WS(\%) \\
\hline $1: 25$ & 88.8 & 75.6 \\
$1: 50$ & 94.1 & 86.1 \\
$1: 100$ & 96.9 & 92.5 \\
$1: 200$ & 98.4 & 96.1 \\
$1: 300$ & 99.0 & 97.4 \\
$1: 400$ & 99.2 & 98.0 \\
$1: 500$ & 99.4 & 98.4 \\
\hline
\end{tabular}

\section{7 Estudos de predição de hélice}

As projeções dos peptídeos análogos a Pln149 em estruturas helicoidais estão mostradas na Figura 52. Nela, podemos observar que há uma notável distribuição preferencial dos resíduos de aminoácidos de modo a formar uma estrutura helicoidal anfipática, onde um dos lados da hélice apresenta caráter mais hidrofóbico, devido a presença majoritária dos resíduos apolares tais como Leu, Ala, Val, Phe, Ile, já o outro lado dessa estrutura, alojam-se os resíduos positivamente carregados de Lys, conferindo a esta região um caráter polar.

No entanto, conforme visto pelas técnicas espectroscópicas anteriormente, este elemento helicoidal não se estabelece na estrutura secundaria dos peptídeos quando estes estão em solução aquosa, mas somente na presença de superfícies negativamente carregadas. Essa característica de formar moléculas anfipáticas em projeções helicoidas, notada em todos os análogos a Pln149 sintetizados, é uma característica típica do grupo de peptídeos antimicrobianos que formam $\alpha$-hélices ao interagirem com seus alvos, como, por exemplo, as cecropinas de insetos e as magaininas isoladas na pele de anfíbios (16).

Os elementos de estrutura secundária com natureza anfipática do peptídeo podem se inserir na membrana celular do microrganismo com as cadeias laterais dos aminoácidos hidrofóbicos embebidas na região das caudas hidrocarbônicas dos lipídios da membrana, e com as cadeias laterais polares dos resíduos de aminoácidos voltadas para o contato com a água. Portanto, inicialmente, grande parte dos AMPs se acomoda paralelamente à superfície da membrana. 


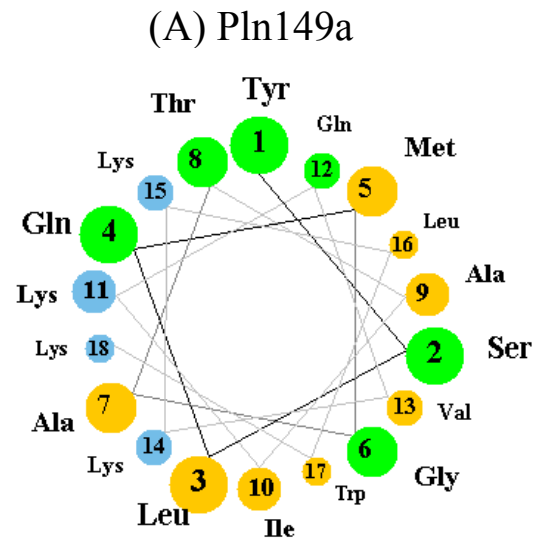

(B) $P \ln 149 \mathrm{~S}$

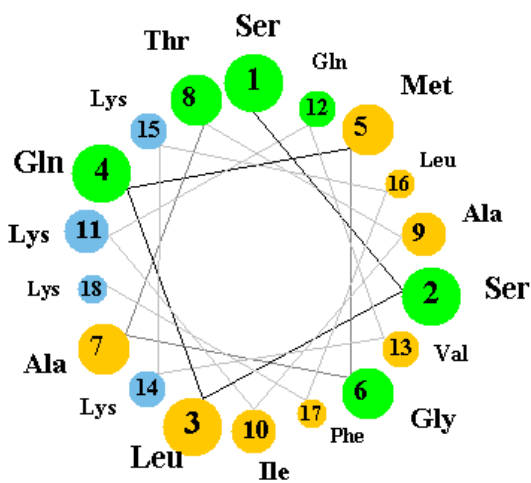

(C) Pln149W

(D) Pln149WS
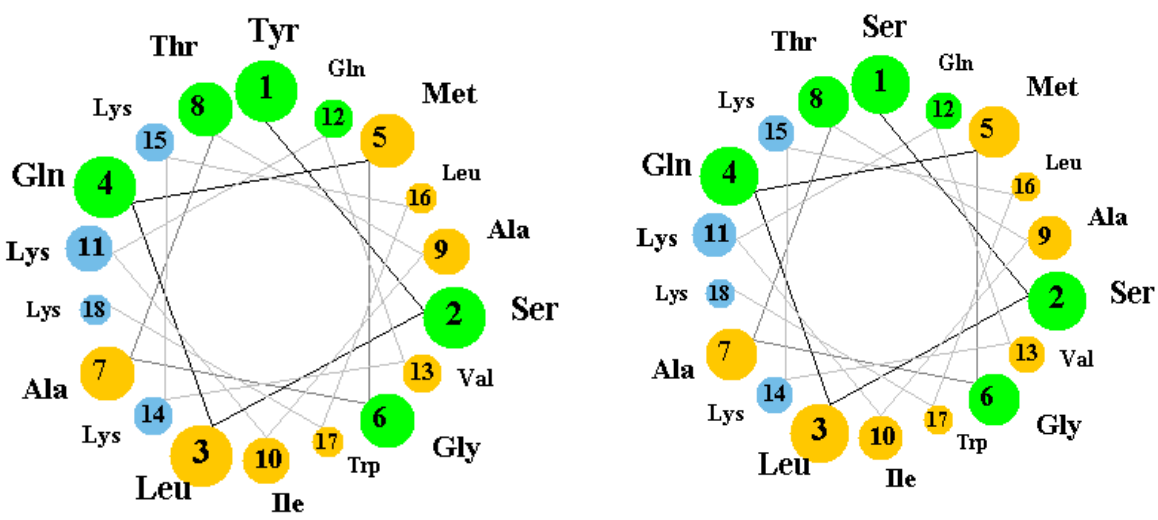

(E) $P \ln 149(6-22)$

(F) $\mathrm{P} \ln 149 \mathrm{~W}(6-22)$
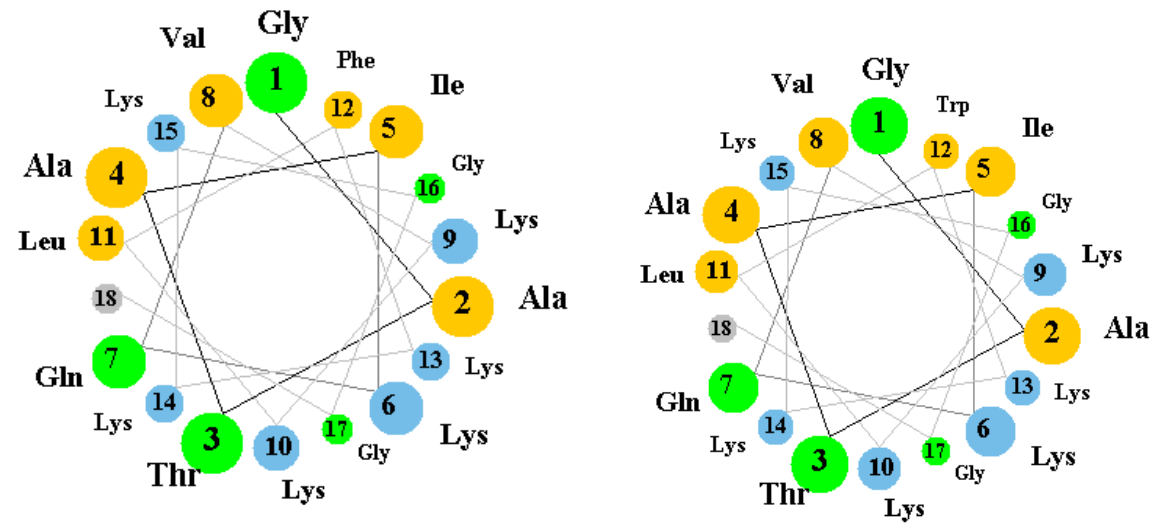

Figura 52 - Projeções helicoidais dos peptídeos sintetizados. As hélices apresentam uma tendência anfipática, onde os resíduos hidrofóbicos estão representados em amarelo, os resíduos carregados são indicados em azul e os não polares, em verde. 


\subsection{Estudos de Tensão Superficial e Elasticidade}

\subsubsection{Peptídeo}

Durante o intervalo de tempo monitorado, pôde-se observar que o peptídeo Pln149a não apresentou atividade superficial sozinho em solução aquosa, mostrado na Figura 53, na qual o valor de tensão superficial monitorado corresponde ao valor de tensão superficial esperado para a água, por volta de $72.8 \mathrm{mN} / \mathrm{m}$.

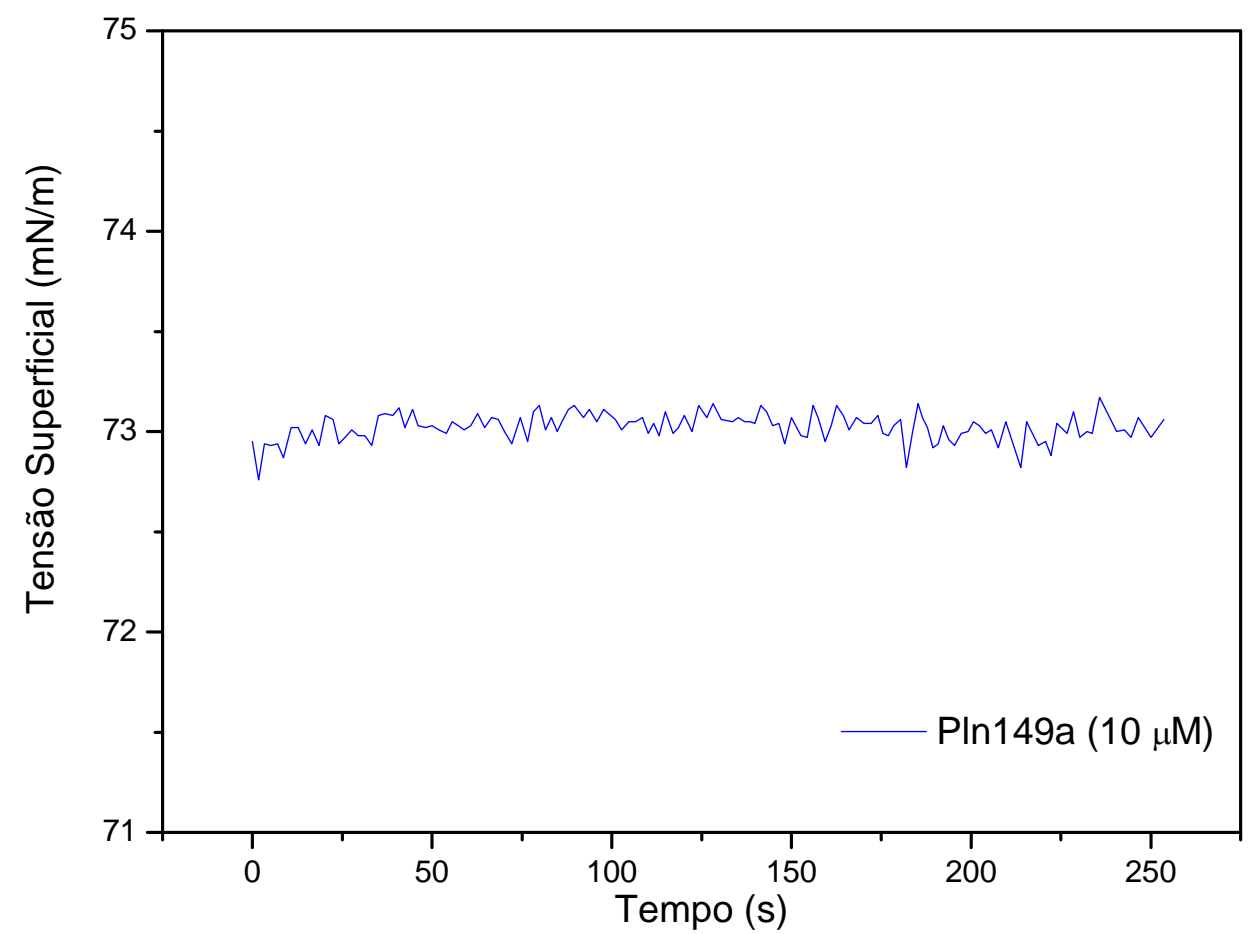

Figura 53 - Medida da tensão superficial de PIn149a em solução aquosa. As propriedades superficiais de Pln149a $(25 \mu \mathrm{g} / \mathrm{mL})$ em água foram monitoradas, observando-se que o peptídeo sozinho não altera a tensão superficial de uma solução aquosa.

\section{8.2 Monocamadas}

A utilização do sistema constituído pelas monocamadas fosfolipídicas nos permitiram estudar as interações dos peptídeos e a penetração destas cadeias nestes modelos simples de membrana. Neste sistema, os fosfolipídios foram espalhados na superfície de uma gota e se 
distribuíram de modo a formar uma monocamada na interface ar-água, acomodando a parte apolar da molécula para o ar.

A investigação das propriedades superficiais de Pln149a na presença de monocamadas de DPPG revelou uma notável diminuição nos valores de tensão superficial nas diferentes concentrações do peptídeo. As curvas da cinética de adsorção do peptídeo sobre as monocamadas de DPPG estão mostradas na Figura 54. Nela, pode-se notar que no intervalo das concentrações de 0.1 a $2 \mu \mathrm{M}$ de Pln149a, a tensão superficial da gota decaiu lenta e quase linearmente, não alcançando o equilíbrio durante o intervalo de tempo monitorado (7 min). Já para as concentrações mais elevadas (4 e $8 \mu \mathrm{M})$, observou-se uma queda mais rápida da tensão superficial nos instantes iniciais, e logo em seguida, as curvas mostraram uma tendência de atingir um valor constante.

Além disso, pode-se notar a diminuição da tensão superficial nas curvas de 0.1 a $2.0 \mu \mathrm{M}$ de $\mathrm{P} \ln 149 \mathrm{a}$ à medida que se aumentou a concentração do peptídeo na solução. Esse efeito foi observado até este valor de $2.0 \mu \mathrm{M}$. Mas, a partir desta concentração, os valores da tensão superficial começaram a aumentar, sugerindo uma mudança brusca no grau de empacotamento das moléculas na monocamada para os valores mais altos da concentração de $\mathrm{P} \ln 149 \mathrm{a}(4$ e $8 \mu \mathrm{M})$.

A incorporação de Pln149a entre os lipídios força um novo empacotamento desta monocamada, provocando um stress nela que perturba este sistema e o torna mais energeticamente desfavorecido. Desta forma, a monocamada suporta esta perturbação até uma concentração limite do peptídeo. A partir deste ponto, qualquer incremento na concentração do peptídeo faz com que a propriedade da monocamada de atuar como uma barreira seja perdida. 


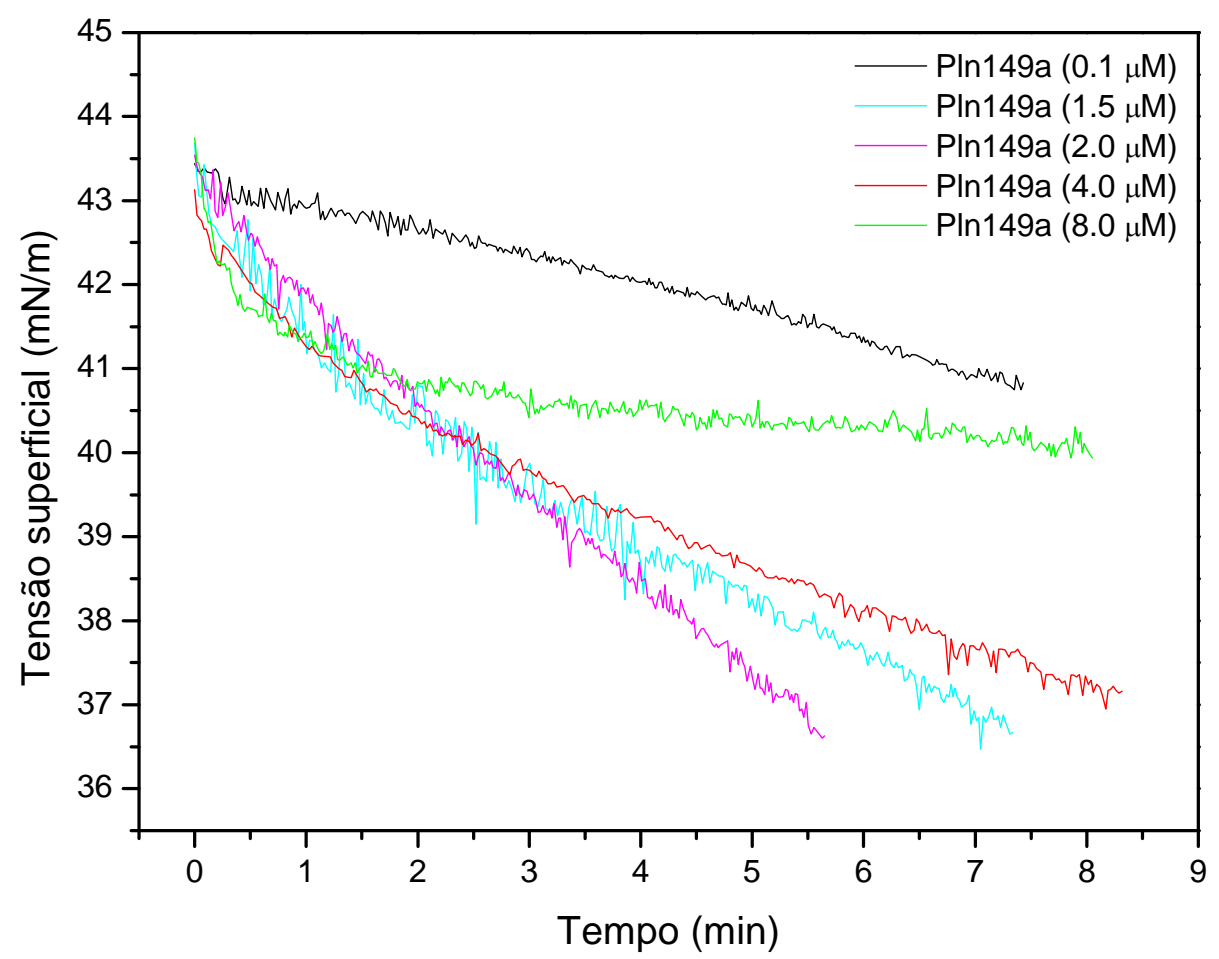

Figura 54 - Medidas da tensão superficial de Pln149a em monocamadas de DPPG. Uma monocamada de DPPG foi depositada sobre uma gota da solução de Pln149a em diferentes concentrações e monitorada o comportamento da tensão superficial da gota.

Os valores de elasticidade superficial $(\varepsilon)$ calculado para as deformações provocadas nas monocamadas de DPPG sugerem que Pln149a apresenta um comportamento dependente da concentração do peptídeo em solução aquosa.

O valor da elasticidade superficial para uma monocamada somente de DPPG foi determinado de $228 \mathrm{mN} / \mathrm{m}$. No entanto, ao adicionarmos pequenas quantidades de Pln149a $(0.1 \mu \mathrm{M})$ para interagir com essa monocamada, observou-se uma grande diminuição deste valor para aproximadamente $100 \mathrm{mN} / \mathrm{m}$. Tal mudança se deve a reorganização da monocamada fosfolipídica devido à presença de pequenas quantidades do peptídeo, que interagem inicialmente com as cargas negativas presentes em DPPG e se acomodam entre as cabeças polares dos fosfolipídios, na interface da monocamada.

Conforme se aumentou a quantidade de peptídeo na solução aquosa (até uma concentração de $2 \mu \mathrm{M}$ ) notou-se também o aumento do valor da pressão superficial inicial, devido ao empacotamento da nova monocamada, que agora era formada pelos fosfolipídios juntamente com o peptídeo, que agora já “sentem” o efeito do empacotamento.

O maior valor de pressão superficial é atingido em $2.5 \mu \mathrm{M}$ do peptídeo. Para este valor, a monocamada está altamente organizada e compacta, de modo que um pequeno 
aumento na concentração do peptídeo resultou numa abrupta queda no valor de pressão superficial, sugerindo a ruptura da monocamada de DPPG, conforme mostrado na Figura 55.

Tal resultado também está de acordo com o obtido nos ensaios de leakage em vesículas de DPPG. Como observado, notou-se um aumento significativo no rompimento dos lipossomos ao passarmos da concentração de 4 para $8 \mu \mathrm{M}$ de Pln149a. Uma vez que nos lipossomos temos uma bicamada fosfolipídica, e que a ruptura da estrutura organizada de uma monocamada de DPPG ocorre em concentrações do peptídeo acima de $2.5 \mu \mathrm{M}$, seriam necessário por volta de $5 \mu \mathrm{M}$ do peptídeo para um vazamento mais efetivo do lipossomo. Este valor está na região onde foi observado o maior vazamento dos lipossomos.

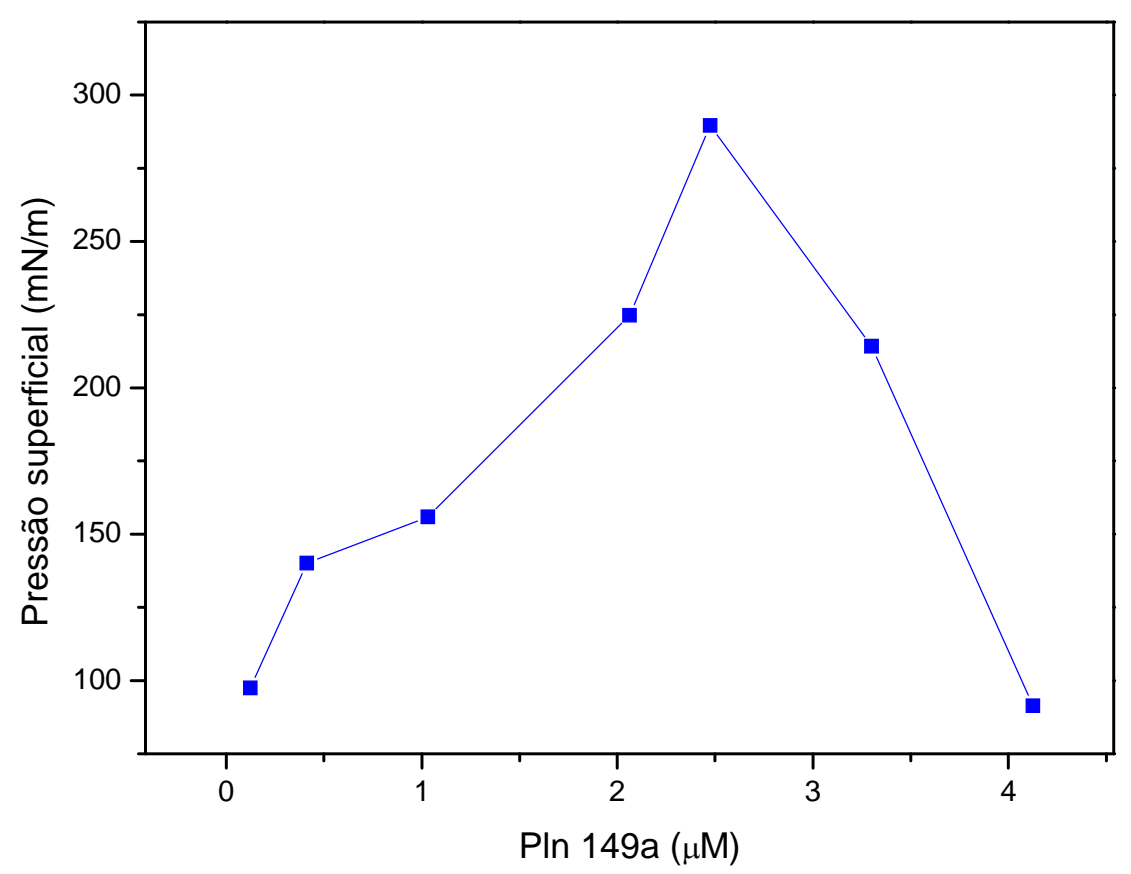

Figura 55 - Comportamento dos valores da elasticidade superficial de Pln149a em monocamadas de DPPG. Um valor crítico para a concentração de Pln149a é observado para a perturbação da integridade dos lipossomos, a partir deste valor, a monocamada se rompe.

Desta maneira, os resultados dos experimentos tanto em mono, como em bicamadas, nos indicam que o peptídeo Pln149a, mais do que ser atraído por efeito eletrostático para a superfície logo acima das cabeças polares de DPPG, deve se ligar à interface das cabeças polares dos fosfolipídios de DPPG, permanecendo envolvido entre elas (104), o que explica as diferenças nos valores de pressão superficial das monocamadas e os vazamentos das sondas dos lipossomos, que culmina com a ruptura destas estruturas. 


\subsubsection{Monocamadas Mistas}

A Figura 56A mostra a cinética de adsorção de Pln149a $(2.5 \mu \mathrm{M})$ nas monocamadas mistas DPPC/DPPG, na qual vemos a diminuição mais acentuada nos valores de tensão superficial para as monocamadas com menor quantidade de DPPG. Este efeito cinético pode refletir a rápida saturação da ligação do peptídeo nestas monocamadas, devido à alta afinidade do peptídeo pelos lipídeos negativos disponíveis.

Dessa forma, ao observar os valores de elasticidade superficial dessas monocamadas na ausência e na presença de Pln149a (Figura 56B) notamos então, maiores alterações no grau de empacotamento das monocamadas a medida que se aumenta a quantidade de DPPG, culminando com a monocamada pura de DPPG, onde ocorre a ruptura da monocamada nessa concentração de peptídeo, conforme discutido anteriormente (Figura 56C).
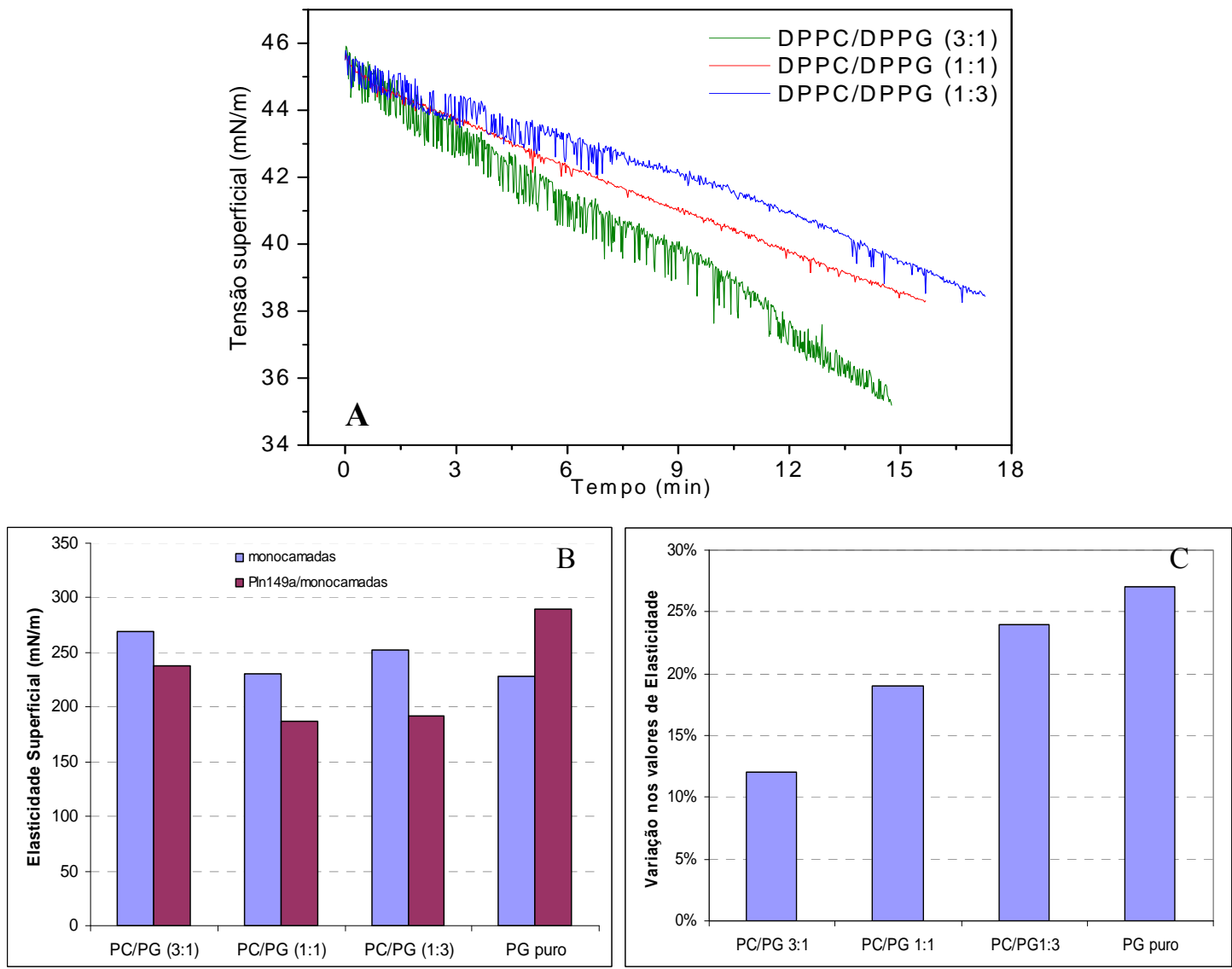

Figura 56 - Cinética de adsorção de Pln149a em monocamadas mistas de DPPC/DPPG (A), valores da elasticidade superficial (B) e variação dos valores de elasticidade superficial (C). A incorporação de $P \ln 149$ a é dependente da densidade de cargas negativas na monocamada. A variação dos valores de elasticidade superficial se deu devido a incorporação de Pln149a na monocamada. 


\subsection{Estudos de Ressonância Plasmônica de Superfície}

\subsubsection{Sensorchip HPA}

A aplicação dos lipossomos sobre a superfície do sensorchip HPA resultou na reconstrução destas estruturas, fazendo com que os fosfolipídios passassem a se re-organizam numa monocamada sobre a superfície do sensorchip. Tal processo foi medido pelo sensorgrama mostrado na Figura 57, que resultou num ganho final de cerca de 1180 unidades de ressonância (RU). Este ganho representa a quantidade de fosfolipídios que foram imobilizados na cela, uma vez que o sinal monitorado corresponde à diferença em RU entre a cela controle e a cela que recebeu a injeção dos lipossomos.

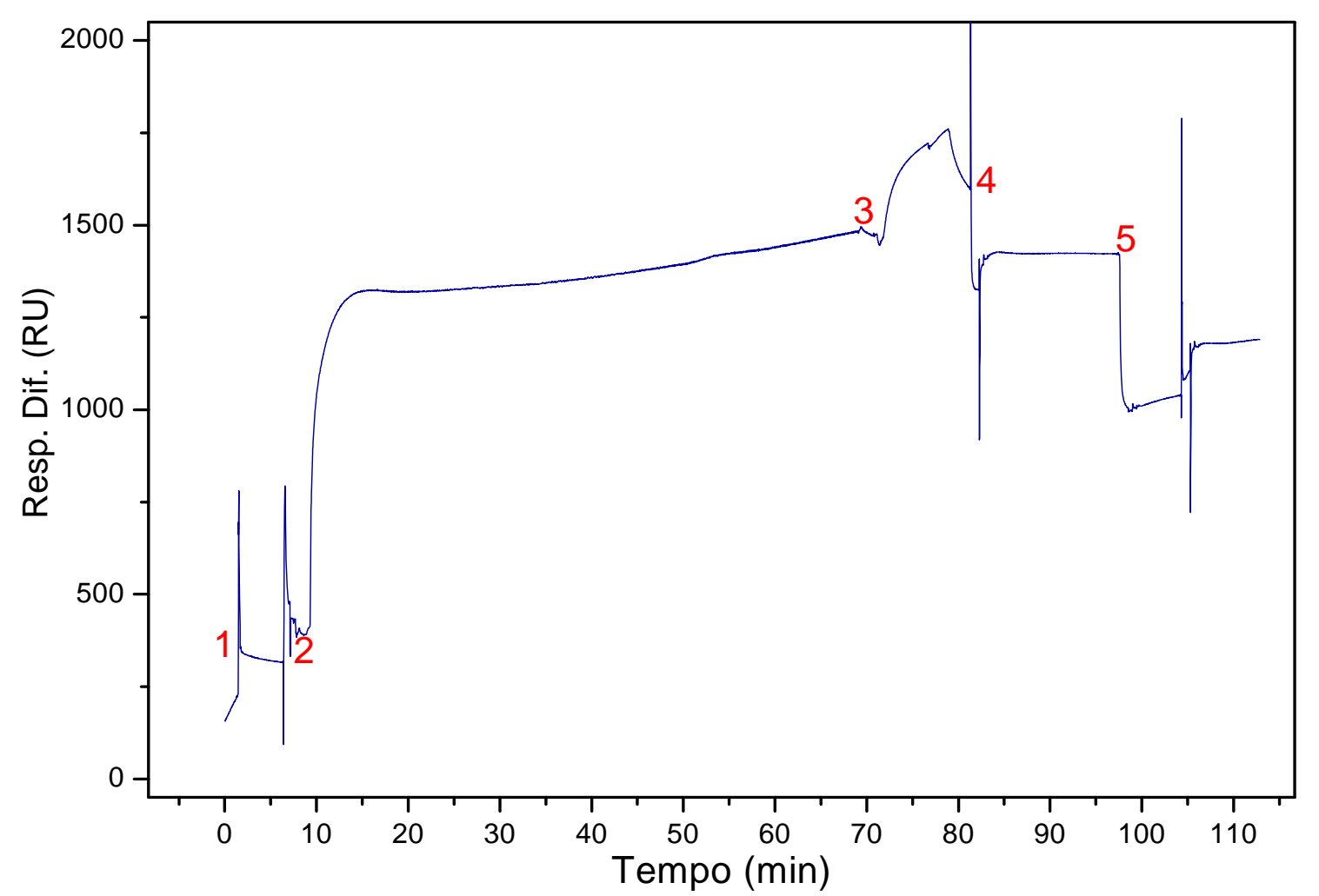

Figura 57 - Sensorgrama da imobilização de uma monocamada de DPPG sobre o sensorchip HPA. Os números em vermelho indicam o inicio de cada etapa, que foram: 1) início da injeção de OGP (40 $\mathrm{mM}$ ), sob um fluxo de $5 \mu \mathrm{l} / \mathrm{min}$; 2) injeção de vesículas de DPPG (1 mM), sob um fluxo de 1 $\mu \mathrm{l} / \mathrm{min}$, 3) aumento do fluxo para $100 \mu \mathrm{L} / \mathrm{min}$; 4) inicio da injeção de $\mathrm{NaOH}$ (4 mM), sob um fluxo de $5 \mu \mathrm{l} / \mathrm{min} ; 5)$ injeção de BSA $(1.5 \mu \mathrm{M})$. 
Uma vez imobilizada a monocamada de DPPG sobre a superfície do chip, esperou-se a estabilização da linha de base (durante 30 minutos de fluxo do tampão de corrida) para realizar os ensaios de interação da Pln149a com a monocamada de DPPG, realizando injeções de diferentes concentrações do peptídeo. Por este ensaio, mostrado na Figura 58, observou-se que o ganho em RU é proporcional ao aumento da concentração do peptídeo, o que representa um aumento na quantidade de peptídeo adsorvido na monocamada lipídica. Além disso, notase que Pln149a promoveu a ruptura da monocamada de DPPG imobilizada sobre o chip, devido à queda na medida em RU ainda durante a fase de associação (intervalo de 0 a 600s) (105).

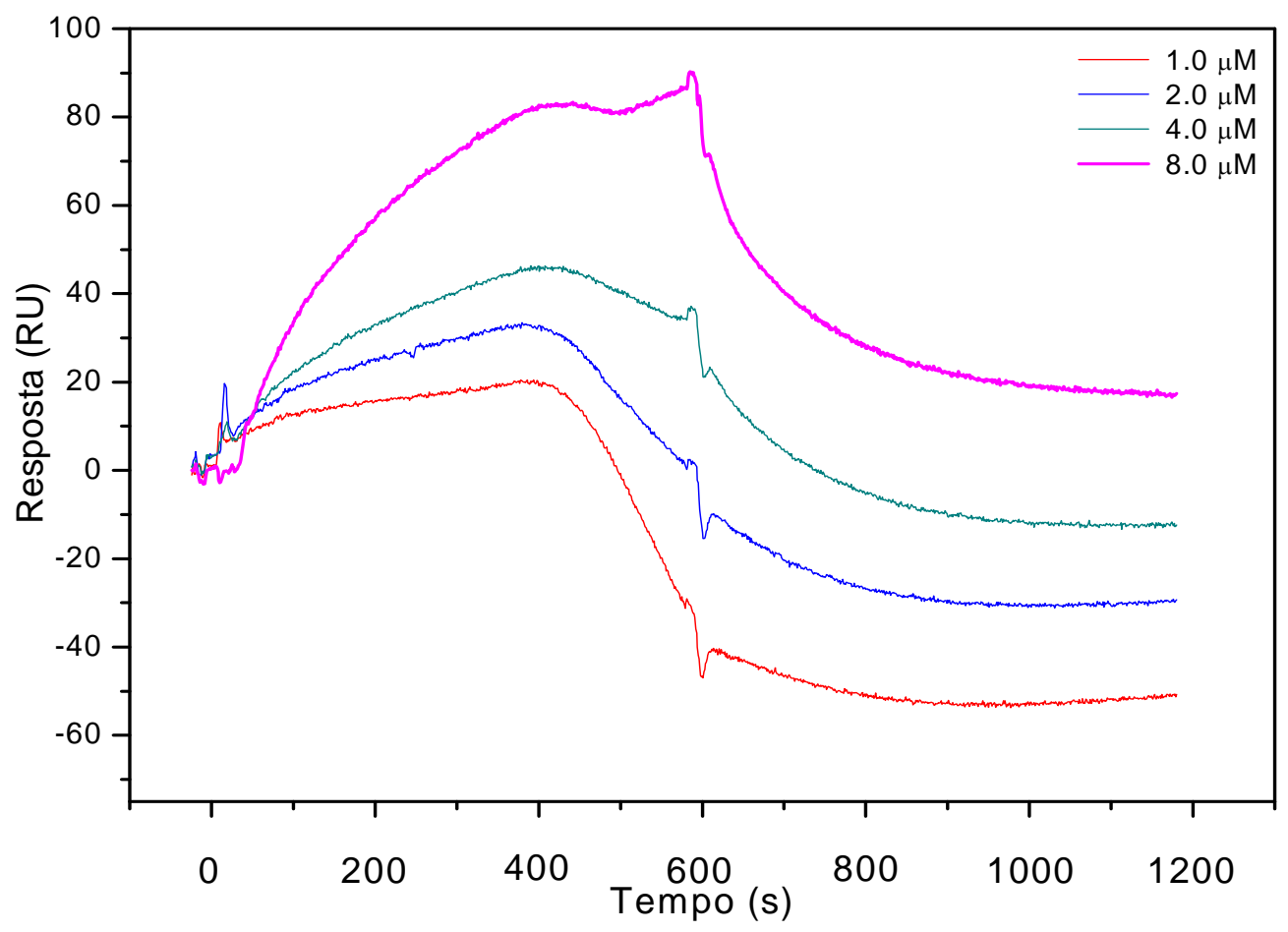

Figura 58 - Sensorgramas da interação de Pln149a com monocamada de DPPG. Diferentes concentrações de Pln149a $(1.0$ a $8.0 \mu \mathrm{M})$ foram injetadas sobre a monocamada de DPPG reconstruída sobre o chip HPA, sob um fluxo de $20 \mu \mathrm{L} / \mathrm{min}$ no tampão Hepes.

\subsubsection{Sensorchip L1}

Neste ensaio, a adsorção de lipossomos na superfície do sensorchip L1 foi monitorada, resultando num ganho final por volta de 6000 RU (Figura 59), cerca de 6 vezes maior do que a obtida na imobilização de DPPG na superfície do chip HPA. Tal aumento se justifica pela imobilização de lipossomos sobre a superfície do sensorchip, que representam uma bicamada lipídica. 


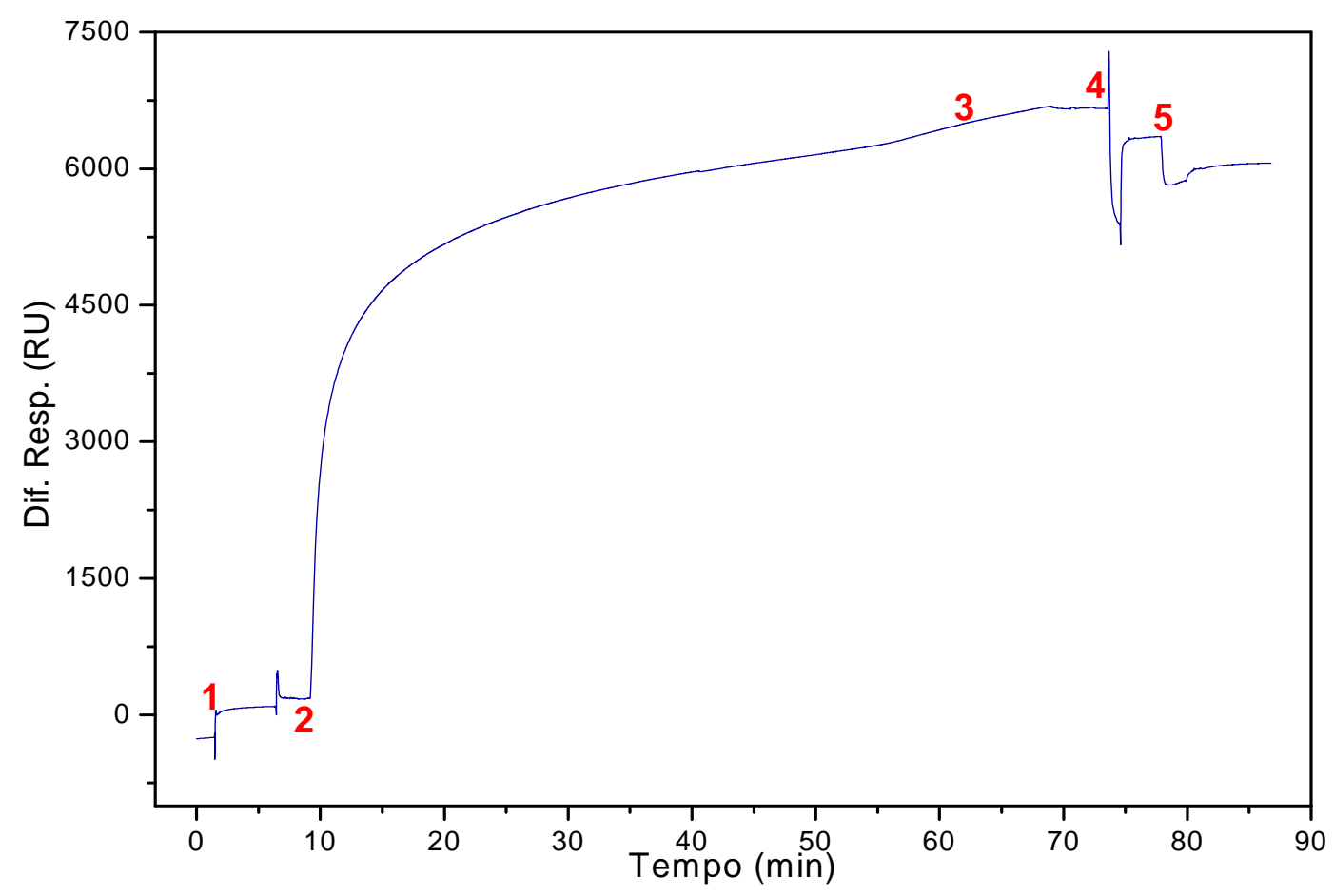

Figura 59 - Sensorgrama da imobilização de uma bicamada de DPPG sobre o sensorchip L1. Os números em vermelho indicam o inicio de cada etapa, que foram: 1) início da injeção de OGP (40 mM), sob um fluxo de $5 \mu \mathrm{l} / \mathrm{min}$; 2) injeção de vesículas de DPPG (1 mM), sob um fluxo de $1 \mu \mathrm{l} / \mathrm{min}, 3)$ aumento do fluxo para $100 \mu \mathrm{L} / \mathrm{min}$; 4) inicio da injeção de $\mathrm{NaOH}(4 \mathrm{mM})$, sob um fluxo de 5 $\mu \mathrm{l} / \mathrm{min}$; 5) injeção de BSA $(1.5 \mu \mathrm{M})$.

Após estabilização da linha de base, por volta de $30 \mathrm{~min}$, iniciaram-se os ensaios da interação da Pln149a com a dupla camada de DPPG, realizando injeções do peptídeo sobre a superfície da bicamada, das quais foram obtidos os sensorgramas mostrados na Figura 60.

Nestas medidas, a interação Pln149a-lipossomo em concentrações mais altas do peptídeo, também resultou na ruptura dos lipossomos imobilizados, vista pelo decréscimo em unidades de ressonância durante a fase de associação, o que sugere a remoção de complexos peptídeo-lipídio da superfície do sensorchip. Tal observação concorda com as estruturas micelares que são formadas pela ação de peptídeos antimicrobianos que desempenham seu mecanismo ação pelo modelo do carpete. 


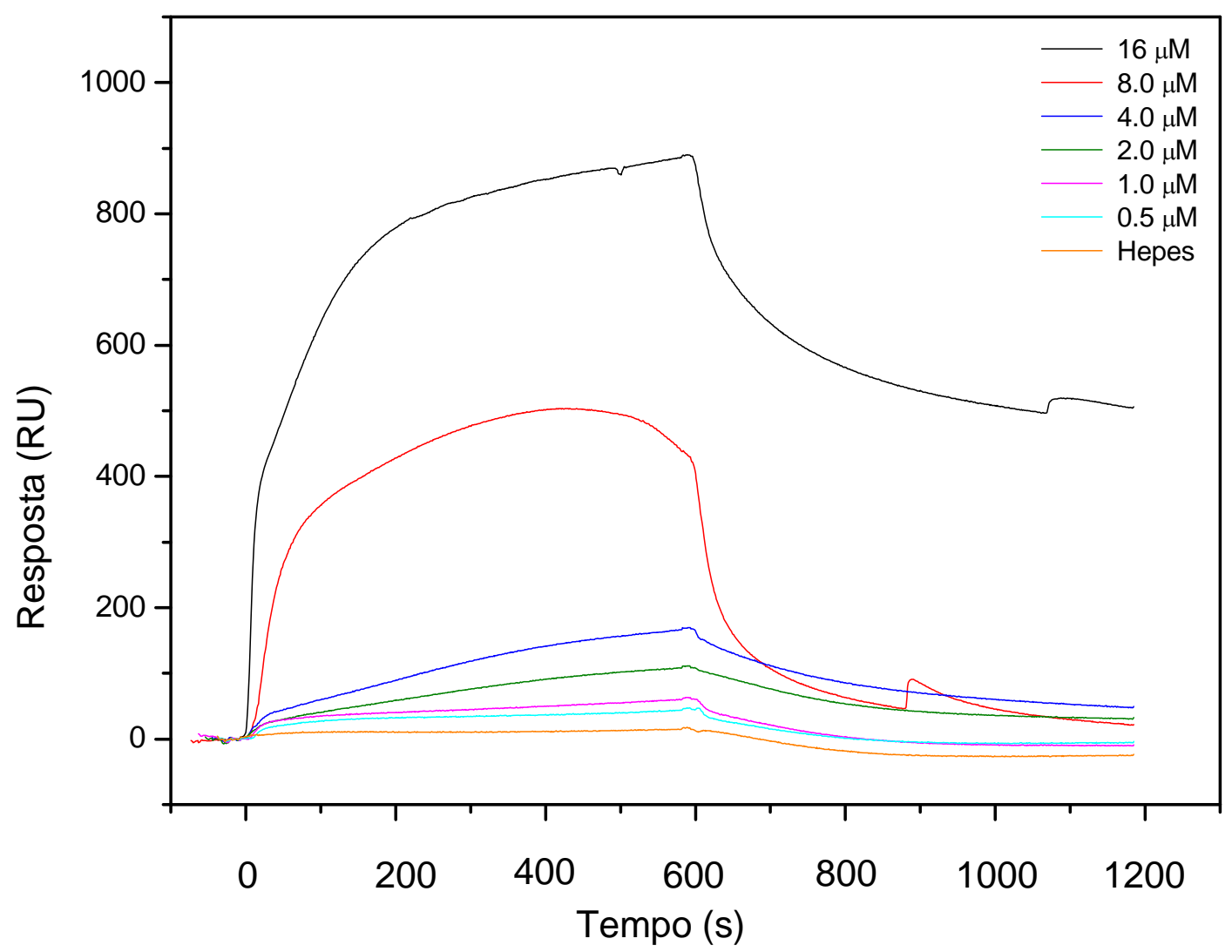

Figura 60 - Sensorgramas da interação de Pln149a com a bicamada de DPPG. Pln149a $(0.5$ a $16 \mu \mathrm{M})$ foi injetada sobre a bicamada de DPPG reconstruída na superfície do chip L1, sob um fluxo de 20 $\mu \mathrm{L} /$ min no tampão Hepes.

Observa-se ainda uma maior adsorção de Pln149a na superfície gerada no sensorchip L1. Isto possivelmente se dá em função da capacidade que o peptídeo encontra nesta superfície para penetrar na bicamada, uma vez que em HPA sua inserção é limitada devido a ligação covalente dos grupos alcanotióis do chip.

Análises quantitativas dos ensaios de SPR, realizadas com o Software BIAevaluation 4.1, tanto para os ensaios realizados no sensorchip HPA, como para os ensaios com o L1, apresentaram altos valores de erros associados às constantes cinéticas (constantes e taxas de associação e dissociação), devido ao fato das curvas experimentais não serem bem ajustadas pelas curvas teóricas calculadas pelo programa (mesmo para concentrações mais baixas do peptídeo). 


\subsection{Ensaios de calorimetria}

\subsubsection{Calorimetria de Varredura Diferencial (DSC)}

Assim como descrito na literatura (106), as vesículas fosfolipídicas puras se caracterizam por apresentar uma transição entre o estado ordenado de gel e a forma desorganizada de cristal-líquido. A transição de fase das vesículas de DPPG em tampão Hepes $5 \mathrm{mM}$ (pH 7.4) ocorreu por volta de $41^{\circ} \mathrm{C}$, conforme observado na Figura 61. Essa transição de fase é um processo endotérmico em que nos termogramas obtidos, pode ser observada como um pico agudo, uma vez que o processo é dito cooperativo, de modo que todas as moléculas passam pela mudança de fase na temperatura de transição (Tm).

As medidas de DSC realizadas permitiram a monitorar as Tm durante a interação de Pln149a e Pln149S com as vesículas negativas de DPPG, e também a dependência dessas temperaturas com as diferentes razões molares de peptídeo/lipídio. Com as curvas de aquecimento foram calculadas as entalpias de transição $(\Delta \mathrm{H})$, através da integração do pico de transição entre os peptídeos e as vesículas em estudo.

Não foi observada uma alteração significativa nos valores de Tm das vesículas de DPPG quando incubadas com as diferentes concentrações dos dois peptídeos, permanecendo por volta dos $41^{\circ} \mathrm{C}$. Os valores de Tm em cada curva estão na Tabela 12.

Além disso, nota-se também um pequeno alargamento do pico de transição nas curvas em que se adicionou o peptídeo na cela do calorímetro. Os valores de $\Delta \mathbf{T}_{\mathbf{1} / \mathbf{2}}$ na Tabela 11 confirmam este aumento, e mostram que há um comportamento crescente para as razões molares de valor até de 125:1. 

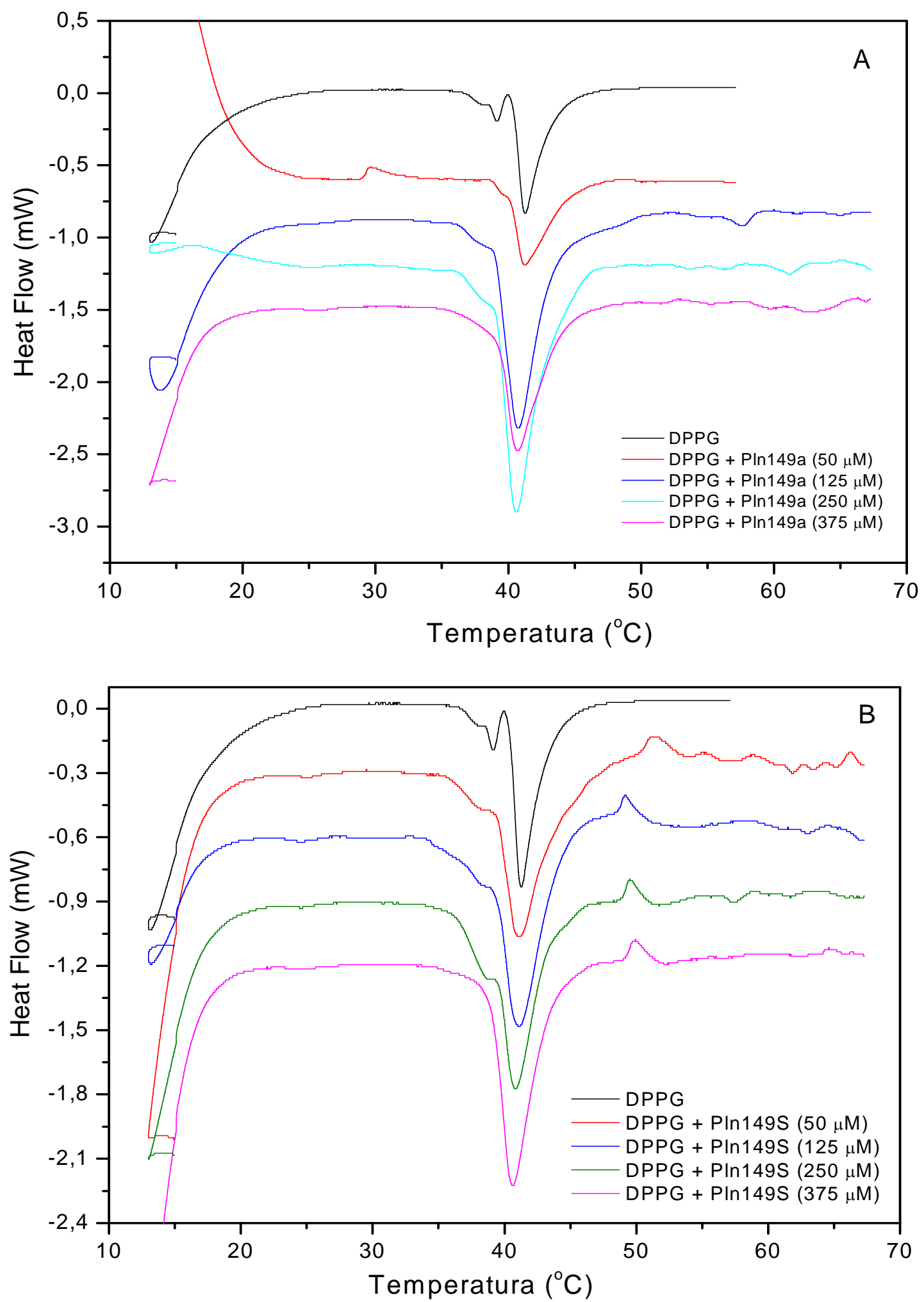

Figura 61 - Curvas termodinâmicas da interação de PIn149a (A) e PIn149S (B) com vesículas de DPPG nas diferentes razões molares. A transição de fase das LUVs de DPPG em tampão Hepes apresenta $\mathrm{Tm}$ centrado em $41^{\circ} \mathrm{C}$. 
Tabela 11: Parâmetros termodinâmicos da interação dos peptídeos com DPPG

\begin{tabular}{rccccc}
\hline & {$[$ Peptídeo] } & $\mathbf{T m}\left({ }^{\mathbf{0}} \mathbf{C}\right)$ & $\Delta_{\mathbf{1} / \mathbf{2}}\left({ }^{\mathbf{O}} \mathbf{C}\right)$ & $\Delta \mathbf{H}(\mathbf{k J} / \mathbf{m o l})$ & $-\boldsymbol{\Delta} \mathbf{T}(\mathbf{K})$ \\
\hline DPPG & 0 & 41.3 & 2.0 & 30.4 & 0.000 \\
Pln149a & 5 & 41.2 & 2.1 & 30.5 & 0.031 \\
& 50 & 41.2 & 2.5 & 35.4 & 0.032 \\
& 125 & 40.8 & 3.2 & 69.7 & 0.509 \\
& 250 & 40.6 & 2.6 & 76.8 & 0.662 \\
& 375 & 40.7 & 3.1 & 50.0 & 0.573 \\
DPPG & 0 & 41.3 & 2.0 & 30.4 & 0.000 \\
Pln149S & 50 & 41.1 & 3.2 & 48.0 & 0.127 \\
& 125 & 40.8 & 3.5 & 53.2 & 0.483 \\
& 250 & 40.6 & 3.2 & 46.5 & 0.637 \\
& 375 & 40.8 & 2.8 & 46.2 & 0.420 \\
\hline
\end{tabular}

Segundo a classificação de Papahadjopoulos (107), existem três modelos genéricos de interação entre moléculas e modelos de membrana. O primeiro deles trata da interação de moléculas hidrofílicas aos lipossomos, neste caso há um aumento na entalpia de transição $\Delta \mathrm{H}$ e pode também ocorrer o aumento do Tm das vesículas. Deste modo, as interações que se produzem com as moléculas de fosfolipídios são puramente eletrostáticas, e os efeitos que se produzem nas vesículas são mínimos e superficiais, não havendo a penetração da molécula para dentro do lipossomo.

O segundo modelo descreve a interação de moléculas anfipáticas que interagem com a vesícula e consegue produzir deformações nela, mas também que não chegam a penetrar na bicamada. A principal diferença ao grupo anterior é que estas moléculas produzem uma diminuição do Tm e também de $\Delta \mathrm{H}$.

Já o terceiro modelo, diz respeito a interação de substancias hidrofóbicas e lipossolúveis com os lipossomos, e não há influencia das cargas eletrostáticas. As moléculas conseguem penetrar na bicamada e facilitam a transição fosfolipídica do estado gel para líquido cristalino, produzindo a diminuição da entalpia $\Delta \mathrm{H}$, e mantendo inalterado o valor de Tm das vesiculas.

Conforme já, discutido anteriormente a interação de Pln149a e Pln149S com os lipossomos envolve etapas que descrevem tanto a interação eletrostática, que deve ocorrer na superfície dos lipossomos, como também a penetração do peptídeo, que provoca a lise da bicamada. Além disso, a hélice que é induzida no peptídeo é uma molécula anfipática. Desta 
forma, Pln149a apresenta características típicas dos três modelos sugeridos, e vemos na Tabela 11 ocorrer uma diminuição discreta dos valores de Tm juntamente com o aumento dos valores de $\Delta \mathrm{H}$, sugerindo que o peptídeo desempenhe sua ação frente as vesículas com etapas provenientes de cada um destes modelos.

Além disso, as curvas de DSC obtidas para Pln149a e Pln149S não apresentam um comportamento regular/linear para as altas relações molares de peptídeo/lipídio testadas (250$500 \mu \mathrm{M})$. Não foi possível observar uma tendência de alargamento das larguras de meia altura dos picos, e/ou alteração significativa dos valores de Tm ou então diminuição dos valores de entalpias.

A limitação para a detecção de sinal deste calorímetro fez com que fossem necessárias altas concentrações de lipídio $(6 \mathrm{mM})$ para monitorar a transição de fase das vesículas. Desta forma, altas concentrações de cada um dos peptídeos (da ordem de $100 \mu \mathrm{M}$ ) eram utilizadas em cada curva.

Deste modo, para a determinação do coeficiente de partição ( K ) dos peptídeos nestas vesículas, foi um empregado um tratamento semelhante ao adotado por Castillo et al (108), onde as curvas de aquecimento das moléculas de surfactantes catiônicos derivados de Arg apresentam um comportamento linear apenas nos valores mais baixos de concentração testados ( 0 a 5 mol\%), e este intervalo foi usada para estimar $\mathrm{K}$ dos peptídeos em estudo.

$\mathrm{Na}$ Figura 62 foram plotadas as dependências dos parâmetros $\mathrm{Tm}$ e $\Delta H$ com a concentração do peptídeo (em mol\%). Destas curvas, selecionaram-se os intervalos de 0-4\% mol de Pn149a e de 0-2\% mol de Pln149S, que representam a região com maior tendência linear destas curvas. Usando estes intervalos, foram plotados os valores de $-\Delta \mathrm{T}$ pela concentração do peptídeo, e pela inclinação da reta, pode-se estimar o valor de $\mathrm{K}$. 

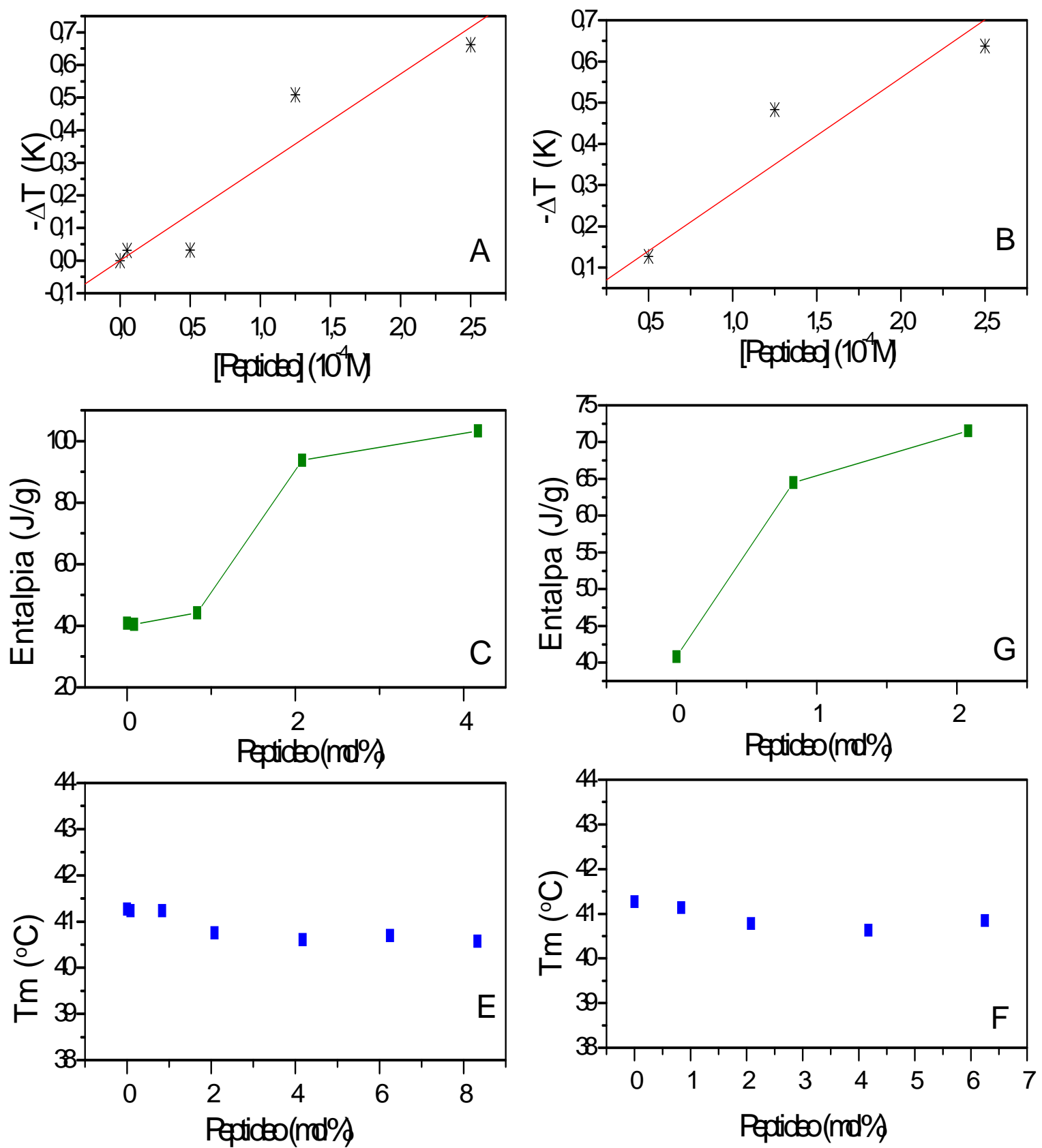

Figura 62 - Dependência dos parâmetros termodinâmicos de $-\Delta T, \Delta H$ e $T$ m das vesiculas fosfolipídicas de DPPG. Tais curvas correspondem a adição de diferentes quantidades de Pln149a (A, C, e E) e Pln149S (B, D e F).

Os valores de $\mathrm{K}_{\text {Pln149a }}$ e K Pln149S foram determinados de $1,61.10^{4}$ e $1,52.10^{4}$,

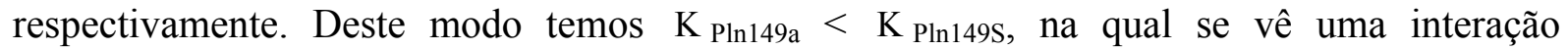
ligeiramente mais forte para $P \ln 149$ a. Esta sutil diferença nos valores destas constantes está de acordo com os resultados anteriores de CD, ITC e Leakage devido a interação do peptídeo Pln149S com os lipossomos ser mais fraca pela diminuição do caráter apolar da molécula na região N-terminal. 


\subsection{2 - Calorimetria de Titulação Isotérmica (ITC)}

Experimentos de ITC foram usados neste trabalho a fim de nos fornecer parâmetros termodinâmicos de interesse tais como a entalpia de reação da interação de Pln149a e Pln149S com os lipossomos de DPPG.

No primeiro experimento, no qual a cela do calorímetro foi preenchida com a suspensão de vesículas lipídicas de concentração definida e pequenas alíquotas $(10 \mu \mathrm{L})$ da solução de Pln149a foram injetadas na cela, determinou-se a entalpia de ligação $\Delta H$. O peptídeo foi diluído por volta de 100 vezes ao injetá-lo na cela que possui volume de $1.4 \mathrm{~mL}$, fazendo com que atingisse concentração por volta de $0.5 \mu \mathrm{M}$, e a razão lipídio/peptídeo na cela foi da ordem de 20 mil. Sob estas condições, o lipídio na cela permaneceu em excesso perante o peptídeo durante toda a titulação. Como a afinidade do peptídeo ao lipídio é muito alta, podemos assumir que todo peptídeo estava susceptível a se ligar quase completamente à superfície das vesículas .

Conforme pode ser visto na Figura 63A que essa titulação se trata de uma reação exotérmica, onde cada injeção promove a liberação do calor de reação $\Delta \mathrm{h}$, com as intensidades dos picos variando em torno de $-0.475 \mu \mathrm{cal} / \mathrm{s}$ nestas 4 titulações, sendo que os calores das injeções consecutivas foram praticamente idênticos. $\mathrm{O}$ calor de cada injeção $\Delta \mathrm{h}$, vista em Figura.63B, foi determinado pela integração de cada pico, logo após a subtração do calor de diluição, determinado num experimento controle separado, onde se injetou apenas o peptídeo no tampão. Desta forma, a ligação de Pln149a em vesículas de DPPG apresenta uma entalpia de ligação $(\Delta \mathrm{H})$ média de $-17.2 \mathrm{kcal} / \mathrm{mol}$.

A ligação de alguns AMPs em modelos de membrana também apresenta variações entalpicas desta mesma ordem de grandeza. Por exemplo a interação do AMP M2a, da classe das magaininas, com vesículas de POPC é acompanhada por uma variação exotérmica de $18.4 \mathrm{kcal} / \mathrm{mol}$ (15). Já a titulação do peptídeo $\beta \mathrm{AP}(1-40)$ em vesículas de POPC/POPG (75/25 mol/mol) produz a liberação de $-14 \mathrm{kcal} / \mathrm{mol}$ (109). A variação do calor determinada durante a ligação de um AMP nos lipossomos reflete o processo global da interação lipídioproteína. Desta forma, o calor liberado da ligação contém contribuições tanto da interação de lipídio-peptídeo como também das alterações resultantes da mudança do conteúdo de estrutural do peptídeo. 


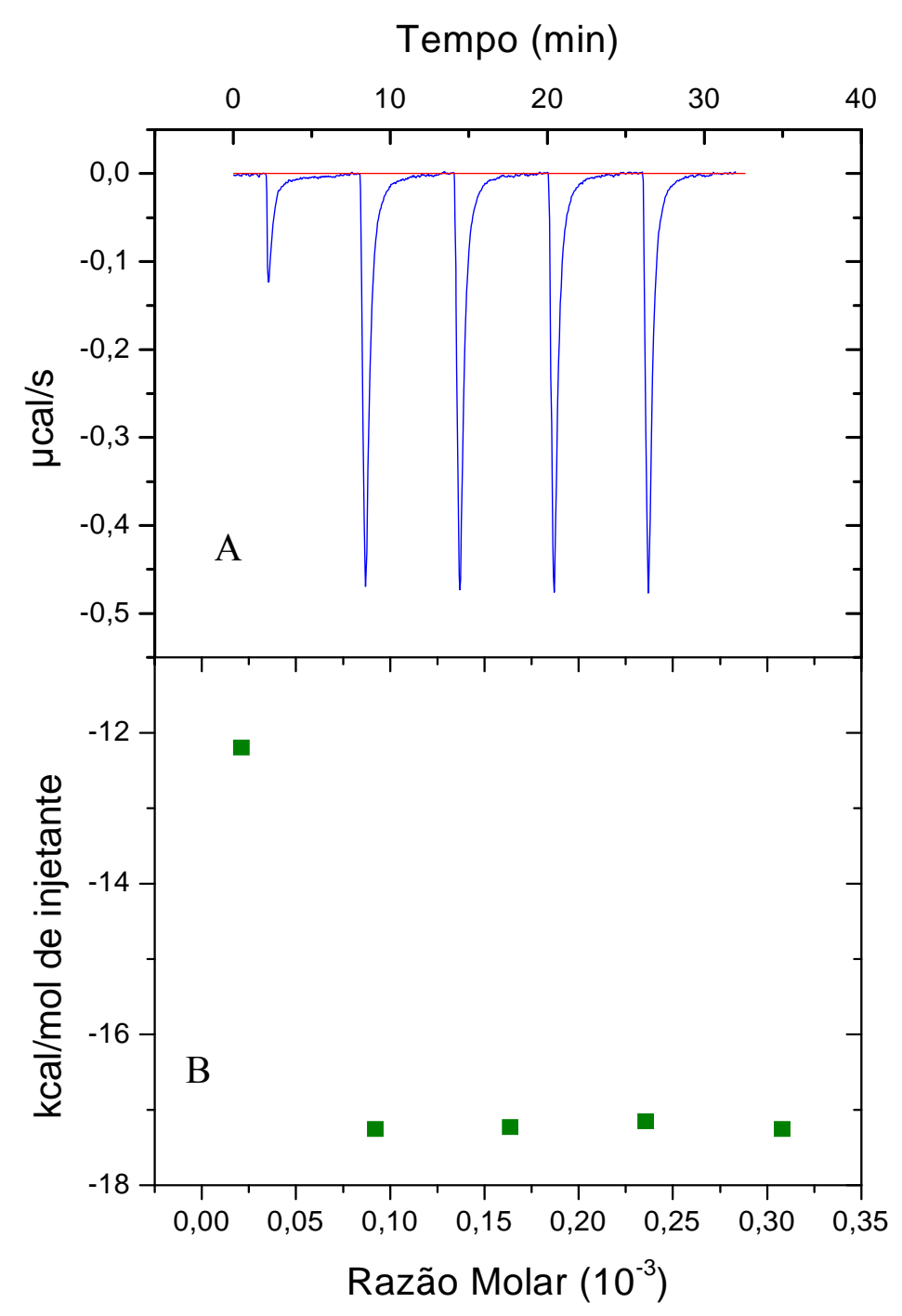

Figura 63 - Medida da entalpia de ligação de PIn149a nas vesículas de DPPG . (A) Curva calorimétrica para a injeção de $10 \mu \mathrm{L}$ de Pln149a $(100 \mu \mathrm{M})$ na cela do calorímetro contendo vesículas de DPPG (10 $\mathrm{mM})$, a $25^{\circ} \mathrm{C}$. (B) Calor de reação por injeção $\Delta \mathrm{h}$, adquirido pela integração da área sob a curva mostrada em A.

No segundo ensaio, a titulação de Pln149S em vesículas de DPPG também mostrou se tratar de uma reação exotérmica, conforme pode ser visto na Figura 64, na qual a intensidade dos picos ficou em torno de $-0.300 \mu \mathrm{cal} / \mathrm{s}$, e a integração cada injeção mostrou que a entalpia de ligação $(\Delta \mathrm{H})$ média de Pln149S em vesículas de DPPG a liberação de $-10.6 \mathrm{kcal} / \mathrm{mol}$

De frente a estes valores, onde temos $\Delta \mathrm{H}_{\mathrm{Pln} 149 \mathrm{a}}>\Delta \mathrm{H}_{\mathrm{Pln} 149 \mathrm{~s}}$, é possível observar mais uma vez que a substituição da Tyr no N-terminal de Pln149 afetou a sua interação com as vesículas, pois tal resíduo tem um papel importante na contribuição entálpica durante a interação, onde foi visto uma diminuição de $38 \%$ da entalpia de ligação para o peptídeo em que a substituição aconteceu. 
O resíduo de tirosina dentro de uma cadeia polipeptídica se associa fortemente aos fosfolipídios quando na presença dos sistemas modelos de membrana (110,111). Em proteínas de membrana, por exemplo, este resíduo apresenta uma distribuição preferencial na estrutura tridimensional da proteína, alojando-se principalmente nas regiões que fazem fronteiras com os segmentos transmembrânicos (112,113), na interface lipídio-aquosa. Portanto, sua substituição em Pln149S enfraquece as interações que são estabelecidas entre o peptídeo nesta interface onde ele deve se localizar.

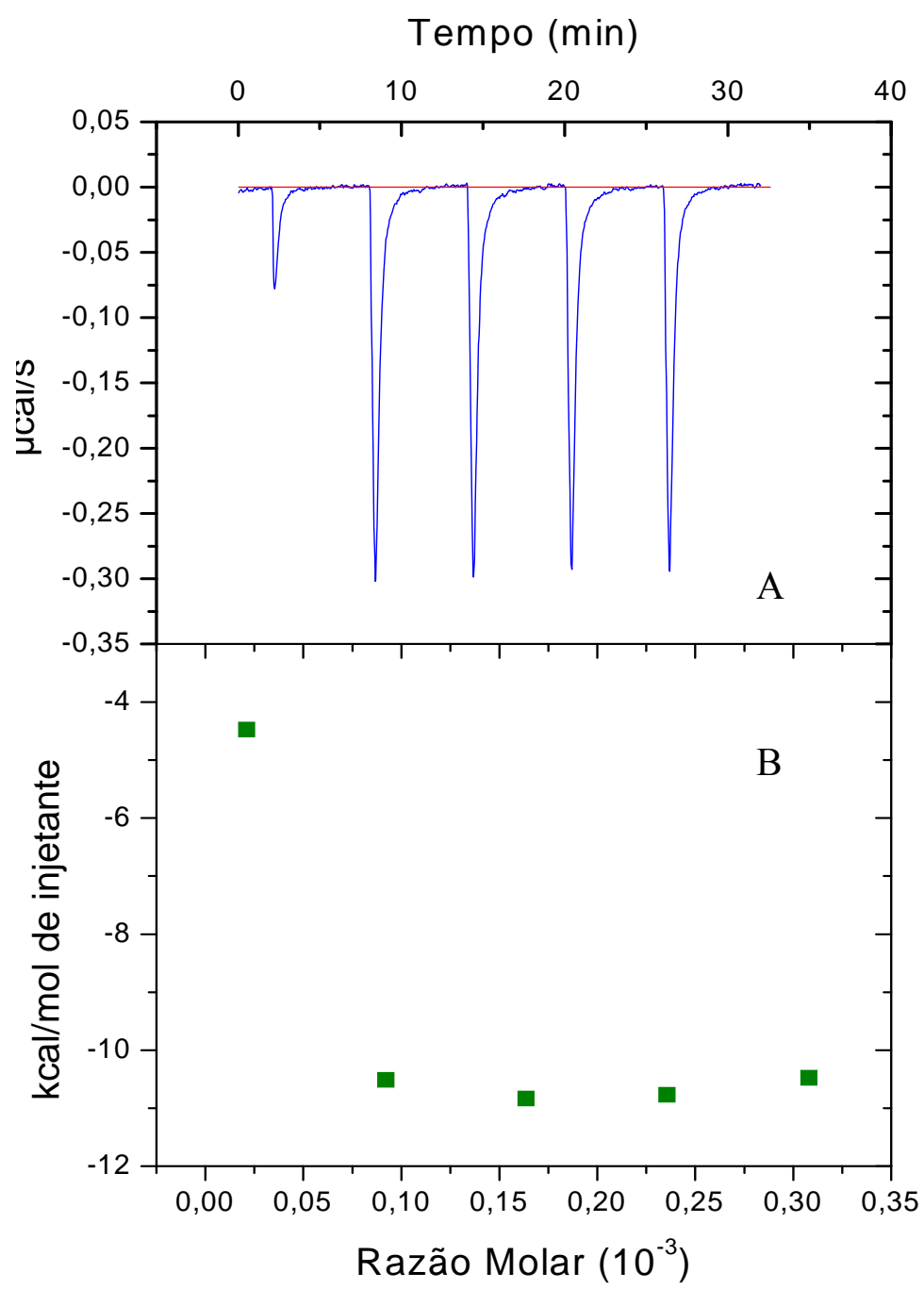

Figura 64 - Medida da entalpia de ligação de Pln149S nas vesículas de DPPG . (A) Curva calorimétrica para a injeção de $10 \mu \mathrm{L}$ de Pln149S $(100 \mu \mathrm{M})$ na cela do calorímetro contendo vesículas de DPPG (10 $\mathrm{mM}$ ), a $25^{\circ} \mathrm{C}$. (B) Calor de reação por injeção $\Delta \mathrm{h}$, adquirido pela integração da área sob a curva mostrada em A. 



\section{CONCLUSÕES}

Neste trabalho, foram realizadas a síntese química e a purificação de peptídeos com atividade antimicrobiana que apresentam estrutura primária análoga ao da Plantaricina149. Todos os peptídeos foram sintetizados, purificados e caracterizados com sucesso.

Por meio de ensaios de inibição do crescimento de microorganismos pôde-se observar a ação lítica destes análogos sobre bactérias Gram-positivas, Gram-negativas, incluindo outra cepa patogênica importante, a Pseudomonas aeruginosa. E ainda leveduras, na qual a atividade sobre S. cerevisiae pode sugerir uma adicional aplicação de Plantaricina149 na industria alimentícia como um processo não-enzimático/não-mecânico para romper as células desta levedura.

Foram também realizadas a investigação das propriedades físico-químicas e o estudo estrutural destes peptídeos com diferentes sistemas modelos de membrana, a fim de sugerir um modelo que descrevesse o mecanismo de ação de tal peptídeo frente aos microrganismos estudados. A seqüência primária de Pln149 apresenta duas regiões distintas, uma mais apolar no lado N-terminal da molécula, e outra positivamente carregada na extemidade C-terminal, conforme mostrado na Figura 65. Ao interagir com membranas fosfolipídicas que apresentam densidade de cargas negativa, a região C-terminal do peptídeo se organiza numa estrutura helicoidal que estabelece contatos eletrostáticos fundamentais entre a hélice anfipática e os fosfolipídios da membrana celular do microrganismo. Esta interação eletrostática também guia o acúmulo de peptídeo em determinadas regiões da membrana celular do microrganismo. Mas, além desses contatos, a interação de Pln149a com as membranas é também um processo dirigido pelas interações hidrofóbicas dos resíduos apolares do N-terminal do peptídeo que devem se alojar na interface lipídica e colaboram no processo de ruptura das biomembranas.

\section{YSLQMGATAIKQVKKLFKKKG G}

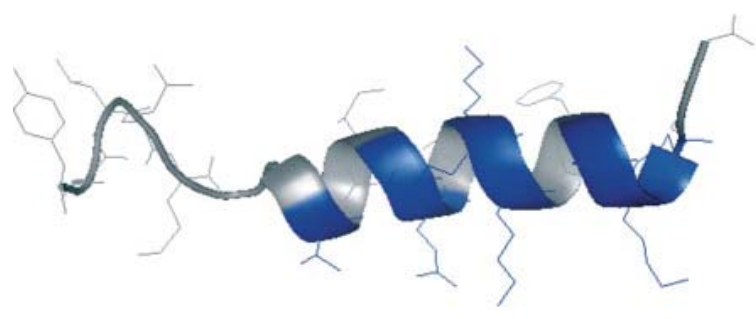

Figura 65 - Modelo criado para a estrutura tridimensional de Pln149a. Resíduos carregados em azul e resíduos hidrofóbicos em verde. Figura retirada de Muller et al (44) 
O modelo proposto para a ação de Pln149 sobre as biomembranas, mostrado na Figura 66, diz que, inicialmente, Pln149a apresenta-se em estrutura randômica em solução aquosa (1), mas é eletrostaticamente atraído para a superfície negativa, induzindo uma $\alpha$-hélice anfipática em sua estrutura (2). O empacotamento da superfície da monocamada é gradualmente alterado para acomodar cada vez mais Pln149a da solução (3), resultando na ruptura da estrutura lipídica (4).

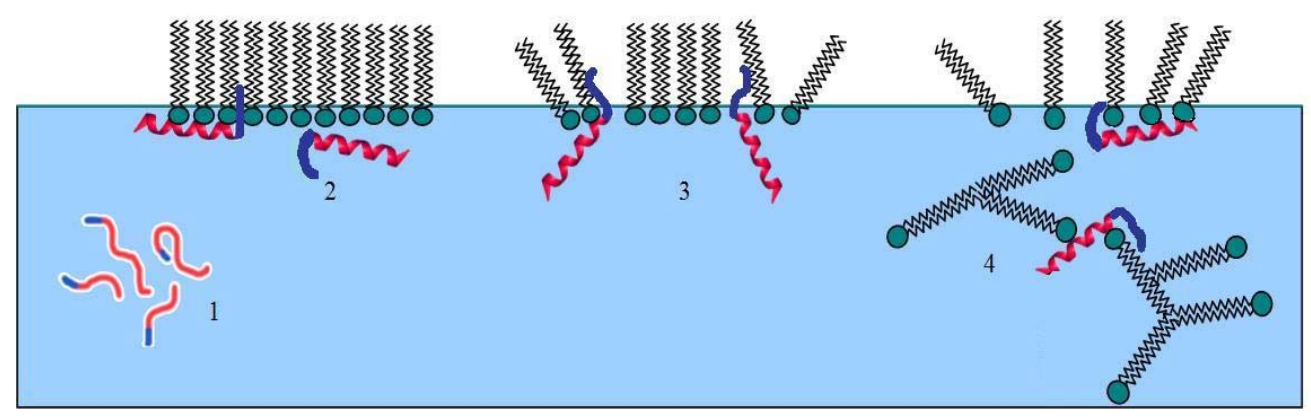

Figura 66 - Modelo proposto para o mecanismo de ação de Pln149a durante sua interação com fosfolipídios negativos. (1) O peptídeo em solução aquosa encontra-se altamente desordenado, mas (2) na presença de uma superfície fosfolipídica com densidade de cargas negativas ele é fortemente atraído e se acumula nestas regiões. Nesta interação, ocorre estruturação do peptídeo em elemento de estrutura secundaria helicoidal. (3) A região N-terminal do peptídeo, em função do seu caráter hidrofóbico, além de contribuir para a manutenção da estrutura helicoidal, estabelece interações hidrofóbicas com a interface lipídica dos fosfolipídios (4) A partir de uma determinada concentração de Pln149a ligado à superfície, o grau de empacotamento dos fosfolipídios da membrana é alterado fortemente, promovendo a lise celular.

Na luta contra o quadro de multiresistência bacteriana, apesar do grande destaque dos AMPs, deve-se também ressaltar que algumas cepas já desenvolveram resistência a toxicidade de alguns peptídeos. No entanto, devido ao grande interesse nestas moléculas, existe um grande numero de novos AMPS que apresentam uma extraordinária atividade e seletividade contra bactérias, o que faz deles candidatos promissores a novos antibióticos. Além disso, na literatura, já se encontram casos onde são reportadas atividade antiviral (115) e anticâncer (116), abrindo cada vez mais aplicações adicionais para esta classe de moléculas. 


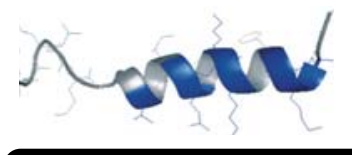

REFERÊNCIAS 



\section{REFERÊNCIAS}

1 WONG, J. Dr. Alexander Fleming and the discovery of penicillin. Primary Care Update for OB/GYNS, v. 10, n. 3, p.124-126, 2003.

2 MAINOUS III, A. G.; POMEROY, C. Management of antimicrobial peptides in infectious diseases: impact of antibiotic resistance. New Jersey: Humana Press, 2001.

3 TOKE, O. . Antimicrobial peptides: new candidates in the fight against bacterial infections. Biopolymers, v.80, n. 6, p.:717-735, 2005.

4 CEROVSKY, V.; SLANINOVA, J.; FUCIK, V. New potent antimicrobial peptides from the venom of Polistinae wasps and their analogs. Peptides, v. 29, n. 6, p. 992-1003, 2008.

5 LEHNINGER, A. L.; NELSON, D. L.; COX, M. M. Princípios de bioquímica. 4a ed. São Paulo: Sarvier, 2006.

6 JENSSEN, H.; HAMILL, P.; HANCOCK, R.E.W. Peptide Antimicrobial Agents. Clinical Microbiology Reviews, v. 19, n. 3, p. 491-511, 2006.

7 MARSHALL, S.H.; ARENAS, G. Antimicrobial peptides: a natural alternative to chemical antibiotics and a potential for applied biotechnology. Electronic Journal of Biotechnology, v. 6, n. 3, p.271-284, 2003.

8 RILEY, M.A.; WERTZ, J.E. Bacteriocin diversity: ecological and evolutionary perspectives. Biochimie, v. 84, n. 5-6, p. 357-364, 2002.

9 BOMAN, H. G. Peptide antibiotics and their role in innate immunity. Annual Reviews of Immunology, v. 13, p. 61-92, 1995.

10 RAMAMOORTHY, A. Biomembranes - Preface. Biochimica et Biophysica Acta, v. 1758, n. 9, p. $1177,2006$. 
11 WANG, Z. WANG, G. APD: the antimicrobial peptide database. Nucleic Acids Res, v. 32, n. SI, p.D590-D592, 2004. DOI: 10.1093/nar/gkh025.

12 LEE, J.Y.; BOMAN, A.; CHUANXIN, S.; ANDERSSON, M.; JORNVALL, H.; MUTT, V., BOMAN, H.G. Antibacterial peptides from pig intestine: isolation of a mammalian cecropin. Proceedings of the National Academy of Sciences of the United States of America, v. 86, n. 23, p. 9159-9162, 1989.

13 ASTHANA, N.; YADAV, S.P.; GHOSH,J.K. Dissection of antibacterial and toxic activity of melittin. A leucine zipper motif plays a crucial role in determining its hemolytic activity but not antibacterial activity. The Journal of Biological Chemistry, v. 279, n. 53, p. 55042-55050, 2004.

14 WENK, M.R.; SEELIG, J. Magainin 2 amide interaction with lipid membranes: calorimetric detection of peptide binding and pore formation, Biochemistry, v. 37, n.11, p. 3909-3916, 1998.

15 WIEPRECHT; T.; APOSTOLOV, O.; SEELIG, J. Binding of the antibacterial peptide magainin 2 amide to small and large unilamellar vesicles. Biophysical Chemistry, v. 85, n. 2-3, p. 187-198, 2000.

16 MATSUZAKI, K. Why and how are peptide-lipid interactions utilized for self-defense? Magainins and tachyplesins as archetypes. Biochimica et Biophysica Acta, v. 1462, n. 1-2, p. 1$10,1999$.

17 DIAMOND, G.; ZASLOFF, M.; ECK, H.; BRASSEUR, M; MALOY, W.L.; BEVINS, C.L. Tracheal antimicrobial peptide, a cysteine-rich peptide from mammalian tracheal mucosa: peptide isolation and cloning of a cDNA. Proceedings of the National Academy of Sciences of the United States of America, v. 88, n. 9, p. 3952-3956, 1991.

18 SELSTED, M.E.; BROWN; D.M.; DELANGE, R.J.; LEHRER, R.I Primary structures of MCP-1 and MCP-2, natural peptide antibiotics of rabbit lung macrophages. Journal of. Biological Chemistry, v. 258, n. 23, p. 4485-4489, 1983.

19 ZHAO, H.; SOOD, R.; JUTILA, A.; BOSE, S.; FIMLAND, G.; NISSEN-MEYER, J.; KINNUNEN, P.K.J. Interaction of the antimicrobial peptide pheromone plantaricin A with model membranes: implications for a novel mechanism of action. Biochimica et Biophysica Acta, v. 1758, n. 9, p. 1461-1474, 2006. 
20 KAVANAGH, K.; DOWD, S. Histatins: antimicrobial peptides with therapeutic potential. Journal of Pharmacy and Pharmacology, v. 56, n. 3, p. 285-289, 2004.

21 RAY, B.; DAESCHEL, M. Food biopreservatives of microbial origin. Boca Ratón: CRC Press, Boca, 1992.

22 ABEE, T., KROCKEL, L., HILL, C. Bacteriocins: modes of action and potentials in food preservation and control of food poisoning. International Journal of Food Microbiology, v.28, n. 2, p. 169-85, 1995.

23 ROLLER, S. The biotechnological development of new food preservatives. Biotechnology Genetical Engeneering, v. 9, p. 183-206, 1991.

24 CLEVELAND, J.; MONTVILLE, T.J.; NES, I.F.; CHIKINDAS, M.L. Bacteriocins: safe, natural antimicrobials for food preservation. International Journal of Food Microbiology, v. 71, n. 1, p. 1-20, 2001.

25 STRAUS, S.K.; HANCOCK, R.E.W. Mode of action of the new antibiotic for Gram-positive pathogens daptomycin: comparison with cationic antimicrobial peptides and lipopeptides. Biochimica et Biophysica Acta, v. 1758, n. 9, p. 1215-1223, 2006.

26 ROSA, C.M.; FRANCO, B.D.G.M. bacteriocinas de bactérias lácticas. ConSCIENTIAE SAÚDE, v. 1, p. 9-15, 2002.

27 BLONDELLE, S.E.; PÉREZ-PAYÁ H. "Synthetic combinatorial libraries: Novel discovery Strategy for identification of antimicrobial agents. In: Antimicrobial agents and Chemotherapy, v. 40, n. 5, p.1067-1071, 1996.

28 BAUER R.; DICKS, L.M.T. Mode of action of lipid II-targeting lantibiotics. International Journal of Food Microbiology, v. 101, n. 2, p. 201-216, 2005.

29 EIJSINK,V.G.H.; SKEIE, M.; MIDDELHOVEN, H.P.; BRURBERG, M.B.; NES, I.F. Comparative studies of class IIa bacteriocins of Lactic acid bacteria. Applied Environmental Microbiology, v. 64, n. 9, p. 3275-3281, 1998. 
30 SITARAM, N.; NAGARAJ, R. Interaction of antimicrobial peptides with biological and model membranes: structural and charge requirements for activity. Biochimica et Biophysica Acta, v. 1462, n. 1-2, p. 29-54, 1999.

31 LA ROCCA, P.; SHAI, Y.; SANSOM, M.S.P. Peptide-bilayer interactions: simulations of dermaseptin B, an antimicrobial peptide. Biophysical Chemistry, v. 76, n. 2, p. 145-159, 1999.

32 OREN, Z.; RAMESH, J.; AVRAHAMI, D.; SURYAPRAKASH, N.; SHAI, N.; SHAI, Y.; JELINEK, R. Structures and mode of membrane interaction of a short $\alpha$-helical lytic peptide and its diastereomer determined by NMR, FTIR, and fluorescence spectroscopy. European Journal of Biochemistry, v. 269, n. 16, p. 3869-3880, 2002.

33 KLAENHAMMER, T.R. Bacteriocins of lactic acid bacteria. Biochemie, v. 70, n. 3, p. 337349, 1998.

34 PIARD, J.C.; DESMAZEAUD, M. Inhibiting factors produced by lactic acid bacteria: 2Bacteriocins and other antibacterial substances. Le Lait, v. 72, n. 2, p.113-142, 1992.

35 McKAY, L.L.; BALDWIN, K.A. Aplications for biotechnology: present and future improvements in lactic acid bacteria: A review. Federation of European Microbiological Societies Microbiology Reviews, v. 7, n. 1-2, p. 3-14, 1990.

36 DE VUYST, L.; VANDAMME, E.J. Bacteriocins of Lactic Acid Bacteria. London: Blackie Academic \& Professional, 1994. p. 409.

37 KELLY, W.J.; ASMUNDSON, R.V.; HUANG, C.M. Characterization of plantaricin kw30, a bacteriocin produced by Lactobacillus plantarum. Journal of Applied Bacteriology, v. 81, n. 6, p. 657-662, 1996.

38 NICOLAS, P.; MOR, A. Peptides as weapons against microorganisms in the chemical defense system of vertebrates. Annual Reviews of Microbiology, v. 49, p. 277-304, 1995.

39 HANCOCK, R.E.W.; FALLA, T.J.; BROWN, M. Cationic bactericidal peptides. In: POOLE, R.K. Advances in Microbial Physiology. London: Academic Press, v. 37, p. 136-175, 1995. 
40 NES, I.F., DIEP, D.B., HAVARSTEIN, L.S., BRURBERG, M.B., EIJSINK, V.G.H; HOLO $\mathrm{H}$. Biosynthesis of bacteriocins in lactic acid bacteria. Antonie van Leeuwenhoek International Journal of General and Molecular Microbiology, v. 70, n. 2-4, p. 113-128, 1996.

41 KATO, T.; MATSUDA, T.; OGAWA, E.; OGAWA, H.; KATO, H.; DOI, U.; NAKAMURA, R. Plantaricin-149 a bacteriocin produced by Lactobacillus plantarum NRIC 149. Journal of Fermentation and Bioengineering, v. 77, n. 3, p. 277-282, 1994.

42 VERELlEN, T.LJ.; BRUGGEMAN, G.; VAN REENEN, C.A.; DICKS, L.M.T.; VANDAMME, E.J. Fermentation optimization of plantaricin 423, a bacteriocin produced by Lactobacillus plantarum 423. Journal of Fermentation and Bioengineering. v. 86, n. 2, p. 174179, 1998.

43 KRISTIANSEN, P.E.; FIMLAND, G.; MANTZILAS, D.; NISSEN-MEYER,J. Structure and mode of action of the membrane-permeabilizing antimicrobial peptide pheromone plantaricin A. Journal of Biological Chemistry, v. 280, n. 24, p. 22945-22950, 2005.

44 MÜlLER, D.M.; CARRASCO, M.S.; SIMONETTA, A.C.; BELTRAMINI, L.M.; TONARELLI, G.G. A synthetic analog of Plantaricin 149 inhibiting food-borne pathogenic bacteria: evidence for $\mathbf{a}$-helical conformation involved in bacteria-membrane interaction. Journal of Peptide Science, v. 13, n. 3, p. 171-178, 2007.

45 MERRIFIELD, R.B. Solid phase peptide synthesis.1. Synthesis of a tetrapeptide. Journal of the American Chemical Society, v. 85, n. 14, p. 2149-2154, 1963.

46 ATHERTON, E.; SHEPPARD, R.C. Solid Phase Peptide Synthesis: a practical approach. Oxford, England: IRL Press, 1989. 203 p.

47 MOORE, M.L.; GRANT, G.A. Peptide design considerations. In GRANT, G. A. Synthetic peptides: a user's guide. New York: Oxford University Press, 2. ed. 1992. p. 9-43.

48 KAISER, E.; COLESCOTT, R.L.; BOSSINGER, C.D.; COOK, P.I. Color test for detection of free terminal amino groups in the solid-phase synthesis of peptides. Analytical Biochemistry, v. 34, n. 2, p. 595-598, 1970.

49 WALSH, K.A; PARMELEE, L.H.D.C.; TITANI,. K. Advances in protein sequencing. Annual Review of Biochemistry, v. 50, p. 261-284, 1981. 
50 ASMS - THE AMERICAN SOCIETY FOR MASS SPECTROMETRY. What is Mass Spectrometry? 3.ed, Los Catos-CA: Edt. Tech. Graphics, 1998. 25 p.

51 NETO, J.G.A.B. Deconvolução de padrões isotopoméricos obtidos de espectros de massa de baixa resolução para obtenção de padrões isotópicos elementares. São Paulo, 2002. 176p. Tese (Doutorado) - Instituto de Química, Universidade de São Paulo. 2002.

52 GASTEIGER, E.; GATTIKER, A.; HOOGLAND, C.; IVANYI, I.; APPEL, R.D.; BAIROCH, A. ExPASy: the proteomics server for in-depth protein knowledge and analysis . Nucleic Acids Research, v. 31, n. 13, p. 3784-3788, 2003.

53 BJEllQViSt, B.; HUGHES, G.J.; PASQUAlI, C.H.; PAQUET, N.; RAVIER, F.; SANCHEZ, J.; FRUTIGER, S.; HOCHSTRASSER, D.F. The focusing positions of polypeptides in immobilized $\mathrm{pH}$ gradients can be predicted from their amino acid sequences. Electrophoresis, v. 14, n. 10, p. 1023-1031, 1993.

54 OHIRA, T.; KATAYAMA, H.; TOMINAGA, S.; TAKASUKA, T.; NAKATSUJI, T.; SONOBE, H.; AIDA, K.; NAGASAWA, H. Cloning and characterization of a molt-inhibiting hormone-like peptide from the prawn Marsupenaeus japonicus. Peptides, v. 26, n. 2, p. 259-268, 2005.

55 PONTIROLI, A.E. Peptide hormones: review of current and emerging uses by nasal delivery. Advanced Drug Delivery Reviews, v. 29, n. 1-2, p. 81-87, 1998.

56 VANDINGENEN, A.; HENS, K.; BAGGERMAN, G.; MACOURS, N.; SCHOOFS, L.; LOOF, A.D.; HUYBRECHTS, R. Isolation and characterization of an angiotensin converting enzyme substrate from vitellogenic ovaries of Neobellieria bullata. Peptides, v. 23, n. 10, p. 1853-1863, 2002.

57 KULKARNI, M.M.; MCMASTER, W.R.; KAMYSZ, W.; MCGWIRE, B.S. Antimicrobial peptide-induced apoptotic death of Leishmania results from calcium-dependent, caspaseindependent mitochondrial toxicity. Journal of Biological Chemistry, v. 284, n. 23, p. 154961504, 2009.

58 POPE, M.E.; SOSTE, M.V.; EYFORD, B.A.; ANDERSON, N.L.; PEARSON, T.W. Antipeptide antibody screening: Selection of high affinity monoclonal reagents by a refined surface plasmon resonance technique. Journal of Immunological Methods, v. 341, n. 1-2, p. 86-96, 2009. 
59 RIBEIRO, S.F.F.; CARVALHO, A.O.. CUNHA, M.D.; RODRIGUES, R.; CRUZ, L.P.; MELO, V.M.M.. VASCONCELOS, I.M.; MELO, E.J.T.; GOMES, V.M. Isolation and characterization of novel peptides from chilli pepper seeds: Antimicrobial activities against pathogenic yeasts. Toxicon, v. 50, n. 5, p. 600-611, 2007.

60 CASTRO, M.S.; FERREIRA, T.C.G.; CILLI, E.M.; CRUSCA JR., E.; MENDES-GIANNINI, M.J.S.; SEBBEN, A.; RICART, C.A.O.; SOUSA, M.V.; FONTES, W. Hylin a1, the first cytolytic peptide isolated from the arboreal South American frog Hypsiboas albopunctatus ("spotted treefrog"). Peptides, v. 30, n. 2, p. 291-296, 2009.

61 BAUER, A.W., KIRBY, W.M.M., SHERRIS, J.C.; TURCK, M. Antibiotic susceptibility testing by a standardized single disc method. American Journal of Clinical Pathology, v. 45, n. 4, p. 493-496, 1966.

62 NATIONAL COMMITTEE FOR CLINICAL LABORATORY STANDARDS. Performance. Standards for Antimicrobial Susceptibility Testing. 4th ed, Wayne, PA: NCCLS; 1999.

63 CAMPBEL, I.D.; DWEK, R.A. Biological Spectroscopy. California: Benjamin Cummings Publish Co. Inc., 1984. 404p.

64 RANJBAR, B.; GILL, P. Circular dichroism techniques: biomolecular and nanostructural analyses- a review. Chemical Biology \& Drug Design, v. 74, n. 2, p.101-120, 2009.

65 NAKANISHI, K; BEROVA, N. WOODY, R.W. Circular Dichroism - principles and applications. New York: VCH publishers, 1994. 570p.

66 KELLY, S.M., PRICE, N.C. The application of circular dichroism to studies of protein folding and unfolding. Biochimica et Biophysica Acta, v. 1338, n. 2, p. 161-185, 1997.

67 SREERAMA, N. VENYAMINOV, S.Y.; WOODY, R.W. Estimation of the number of $\alpha-$ helical and $\beta$-strand segments in proteins using CD spectroscopy. Protein Science, v. 8, n. 2, p. 370-380, 1999.

68 SREERAMA, N., WOODY, R.W. Estimation of protein secondary structure from circular dichroism spectra: comparison of CONTIN, SELCON, and CDSSTR methods with and expanded reference set. Analytical Biochemistry, v. 287, n. 2, p. 252-260, 2000. 
69 SREERAMA, N., VENYAMINOV, S.Y., WOODY, R.W. Analysis of protein circular dichroism spectra based on the tertiary structure classification. Analytical Biochemistry, v. 299, $\mathrm{n}$. 2, p. 271-274, 2001.

70 COMPTON, L.A.; JOHNSON, WC Jr. Analysis of protein circular dichroism spectra for secondary structures using a simple matrix multiplication. Analytical Biochemistry, v. 155, n. 1, p. 155-167, 1986.

71 PANCOSKA, P.; KEIDERLING, T.A. Systematic comparison of statistical analysis of electronic and vibrational circular dichroism for secondary structure prediction of selected proteins. Biochemistry, v. 30, n. 28, p. 6885-6895, 1991.

72 YANG, J.T.; WU, C.S.C. ; MARTINEZ, H.M. Calculation of protein conformation from circular dichroism. Methods in Enzymology, v. 130, p. 208-269, 1986.

73 CHEN, Y.H.; YANG, J.T.; CHAU, K.H. Determination of the helix and beta form of proteins in aqueous solution by circular dichroism. Biochemistry, v. 13, n. 16, p. 3350-3359, 1974.

74 LAKOWICZ, J. R. Principles of Fluorescence Spectroscopy. New York: Edt. Plenum Publishers, 2.ed. 1999.

75 LADOKHIN, A.S.; JAYASINGHE, S.; WHITE, S.H. How to measure and analyze tryptophan fluorescence in membranes properly, and why bother? Analytical Biochemistry, v.285, n. 2, p. 235-245, 2000.

76 McClARE, C.W. An accurate and convenient organic phosphorus assay. Analytical Biochemistry, v. 39, n. 2, p. 527-530, 1971.

77 CHRISTIAENS, B.; SYMOENS, S.; VERHEYDEN, S.; ENGELBORGHS, Y.; JOLIOT, A.; PROCHIANTZ, A.; VANDEKERCKHOVE, J.; ROSSENEU, M.; VANLOO, B.; VANDERHEYDEN, S. Tryptophan fluorescence study of the interaction of penetratin peptides with model membranes. European Journal of Biochemistry, v. 269, n.12, p.2918-2926, 2002.

78 DAVIES, J.T., RIDEAL, E.K. Interfacial phenomena. New York: Academic Press, 1963. 
79 MARSH, D. Lateral pressure in membranes. Biochimica et Biophysica Acta, v. 1286, n. 3, p.183-223, 1996.

80 WILSON, W.D. Analyzing biomolecular interactions. Science, v. 295, n. 5562, p. 2103-2105, 2002.

81 BIACORE X Booklet: getting started. Version AA. [S.1]: Bioacore AB, 2002. 52 p.

82 HALL, K.; MOZSOLITS, H.; AGUILAR, M.I. Surface plasmon resonance analysis of antimicrobial peptidc membrane interactions: affinity \& mechanism of action. Letters in Peptide Science, v. 10, n. 5-6, p. 475-485, 2003.

83 XIE, W.; KANIA-KORWEL, I.; BUMMER, P.M.; LEHMLER, D.H.J. Effect of potassium perfluorooctanesulfonate, perfluorooctanoate and octanesulfonate on the phase transition of dipalmitoylphosphatidylcholine (DPPC) bilayers. Biochimica et Biophysica Acta (BBA) Biomembranes, v.1768, n. 5, p.1299-1308, 2007.

84 OREN, Z.; SHAI, Y. Mode of action of linear amphipathic $\alpha$-helical antimicrobial peptides. Peptide Science, v. 47, n. 6, p. 451-463, 1999.

85 BESSALLE, R.; HAAS, H.; GORIA, A.; SHALIT, I.; FRIDKIN, M. Augmentation of the antibacterial activity of magainin by positive-charge chain extension. Antimicrobial Agents Chemotherapy, v. 36, n. 2, p. 313-317, 1992

86 DATHE, M.; NIKOLENKO, H.; MEYER, J.; BEYERMANN, M.; BIENERT, M. Optimization of the antimicrobial activity of magainin peptides by modification of charge. Federation of European Biochemical Societies Letters, v. 501, n. 2, p. 146-150, 2001.

87 LOPES, J.L.S.; NOBRE, T.M.; SIANO, A.; HUMPOLA, V.; BOSSOLAN, N.R.S.; ZANIQUELLI, M.E.D.; TONARELLI, G.; BELTRAMINI, L.M. Disruption of Saccharomyces cerevisiae by Plantaricin 149 and investigation of its mechanism of action with biomembrane model systems. Biochimica et Biophysica Acta - Biomembranes, v. 1788, n. 10, p. 2252-2258, 2009.

88 OTVOS L JR, SNYDER C, CONDIE B, BULET P, WADE J. D. Chimeric antimicrobial peptides exhibit multiple modes of action. International Journal of Peptide Research and Therapeutics, v.11, n. 1, p. 29-42, 2005. 
89 ZELEZETSKY I, PACOR S, PAG U, PAPO N, SHAI Y, SAHL HG, TOSSI A. Controlled alteration of the shape and conformational stability of alpha-helical cell-lytic peptides: effect on mode of action and cell specificity. Biochemistry Journal, v. 390, n. 1, p. 177-188, 2005.

90 BLONDELLE, S.E.; LOHNER, K.; AGUILAR, M.I. Lipid-induced conformation and lipidbinding properties of cytolytic and antimicrobial peptides: determination and biological specifity. Biochimica et Biophysica Acta, v. 1462, n. 1-2, p. 89-108, 1999.

91 PARK, J.M.; JUNG, J.E.; LEE, B.J. Antimicrobial peptides from the skin of a Korean frog, Rana rugosa. Biochemical and Biophysical Research Communication, v. 205, n. 1, p. 948-954, 1994.

92 ROLLINS-SMITH, L.A.; REINERT, L.K.; O’LEARY, C.J.; HOUSTON, L.E.; WOODHAMS, D.C. Antimicrobial peptide defenses in amphibian skin. Integrative and Comparative Biology, v. 45, n. 1, p. 137-142, 2005.

93 YEAMAN MR, YOUNT NY. Mechanisms of antimicrobial peptide action and resistance. Pharmacological Reviews, v. 55, n. 1, p. 27-55, 2003.

94 SUN, Z.J.; LI, S.Y.; LV, G.J.; ZHU, J.; YU, W.T.; WANG, MA, W.; X. Metabolic response of different osmo-sensitive Sacchromyces cerevisiae to ACA microcapsule. Enzyme and Microbial Technology, v.42, n. 7, p. 576-582, 2008.

95 BHARATHAM, K.; BHARATHAM, N.; PARK, K.H.; LEE, K.W. Binding mode analyses and pharmacophore model development for sulfonamide chalcone derivatives, a new class of $\alpha$ glucosidase inhibitors. Journal of Molecular Graphics and Modelling, v. 26, n. 8, p. 1202-1212, 2008 .

96 CHUPAKHINA, S.; KOTTKE, V. Using a yeast cell layer as a secondary membrane in microfiltration. Desalination, v. 224, n. 1-3, p. 18-22, 2008.

97 RADIVOJAC, P.; et al. Intrinsic disorder and functional proteomics. Biophysical Journal, v. 92, n. 5, p. 1439-1456, 2007. 
98 LEITE, J.R.S.A.; G.D.; BRAND, L.P.; SILVA, KÜCKELHAUS, S.A.S.; BENTO, W.R.C.; ARAÚJO, A.L.T.; MARTINS, G.R.; LAZZARI, A.M.; BLOCH JR, C. Dermaseptins from Phyllomedusa oreades and Phyllomedusa distincta: secondary structure, antimicrobial activity, and mammalian cell toxicity. Comparative Biochemistry and Physiology, Part A, v. 151, n. 3, p. 336-343, 2008.

99 KOO, Y.S.; KIM, J.M.; PARK, I.Y.; YU, B.J.; JANG, S.A; KIM, K.S.; PARK, C.B.; CHO, J.H.; KIM, S.C. Structure-activity relations of parasin I, a histone H2A-derived antimicrobial peptide. Peptides, v. 29, n. 7, p. 1102-1108, 2008.

100 HANSEN, J.C.; LU, X.; ROSS, E.D.; WOODY, R.W. Intrinsic protein disorder, amino acid composition, and histone terminal domains. Journal of Biological Chemistry, v. 281, n. 4, p. 1853-1856, 2006.

101 BERNSTEIN, L.S.; GRILLO, A.A.; LORANGER, S.S.; LINDER, M.E. RGS4 binds to membranes through an amphipathic $\alpha$-helix. The Journal of Biological Chemistry, v. 275, n. 24, p. 18520-18526, 2000.

102 ABRIOUEL, H.; VALDIVIA, E.; GÁlVEZ, A.; MAQUEDA, M. Influence of physicochemical factors on the oligomerization and biological activity of bacteriocin AS-48. Current Microbiology. v. 42, n. 2, p. 89-95, 2001.

103 SEELIG, J. Thermodynamics of lipid-peptide interactions. Biochimica et Biophysica Acta, v. 166, n. 1-2, p. 40-50, 2004.

104 EPAND, R.M. Role of membrane lipids in modulating the activity of membrane-bound enzymes. In: YEAGLE, P.L. The structure of biological membrane. London: CRC Press, 1991. 2.ed. p. 573-601

105 MOZSOLITS, H.; AGUILAR, M.I. Surface plasmon resonance Spectroscopy: an emerging tool for the study of peptide-membrane interactions. Peptide Science, v. 66, n. 1, p. 3-18, 2002.

106 LEWIS, R.N.A.H.; McELHANEY, R.N. The Mesomorphic Phase Behavior of Lipid Bilayers. In: YEAGLE, P.L. The structure of biological membranes. London: CRC Press, 2.ed, p. 53-120, 2005. 
107 PAPAHADJOPOULOS, D.; MOSCARELLO, M.; EYLAR, E.H.; ISAC, T. Effects of protein on thermotropic phase transition of phospholipd membranes. Biochimica et Biophysica Acta, v. 401, n. 3, p. 317-335, 1975.

108 CASTILlO, J.A.; PINAZO, A.; CARILlA, J.; INFANTE, M.R.; ALSINA, M.A.; HARO, I.; CLAPÉS, P. Interaction of antimicrobial arginine-based cationic surfactants with liposomes and lipid monolayers. Langmuir, v. 20, n. 8, p 3379-3387, 2004.

109 TERZI, E.; HOLZEMANN, G.; SEELIG, J. Self-association of b-amyloid peptide (1-40) in solution and binding to lipid membranes. Journal of Molecular Biology, v. 252, n. 5, p. 633-642, 1995.

110 ULMSCHNEIDER, M.B.; SANSOM, M.S. Amino acid distributions in integral membrane protein structures. Biochimica et Biophysica Acta, v. 1512, n. 1, p. 1-14, 2001.

111 SANDERSON, J.M.; WHELAN, E.J. Characterization of the interactions of aromatic amino acids with diacetyl phosphatidylcholine. Physical Chemistry Chemical Physics, v. 6, p.10121017, 2004.

112 LANDOLT-MARTICORENA, C.; WILLIAMS, K.A.; DEBER, C.M.; REITHMEIER, R.A. Non-random distribution of amino acids in the transmembrane segments of human type I single span membrane proteins. Journal of Molecular Biology, v. 229, n. 3, p. 602-608, 1993.

113 SANDERSON, J.M. Peptide-lipid interactions: insights and perspectives. Organic and Biomolecular Chemistry, v. 3, n. 2, p. 201-212, 2005.

114 SEELIG, J. Titration calorimetry of lipid-peptide interactions. Biochimica et Biophysica Acta, v. 1331, n. 1, p.103-116, 1997.

115 CARRIEL-GOMES, M.C.; KRATZ, J.M.; BARRACCO, M.A.; BACHÉRE, E.; BARARDI, C.R.M.; SIMÕES, C.M.O. In vitro antiviral activity of antimicrobial peptides against herpes simplex virus 1, adenovirus, and rotavirus. Memorias do Instituto Oswaldo Cruz, v.102, n. 4, p. 469-472. 2007.

116 HOSKIN, D.W.; RAMAMOORTHY, A. Studies on anticancer activities of antimicrobial peptides. Biochimica et Biophysica Acta, v. 1778, n. 2, p. 357-375, 2008. 


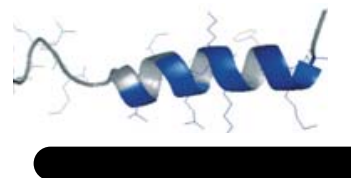

ANEXOS 



\section{ANEXOS}

Em anexo a esta tese, seguem os artigos científicos publicado/em fase de publicação, referentes à pesquisa desenvolvida neste doutoramento. São eles:

1) LOPES, JOSÉ LUIZ S.; NOBRE, T.M. ; SIANO, A.; HUMPOLA, V.; BOSSOLAN, N.R.S.; ZANIQUELLI, M.E.D.; TONARELLI, G.; BELTRAMINI, L.M. Disruption of Saccharomyces cerevisiae by Plantaricin 149 and investigation of its mechanism of action with biomembrane model systems. Biochimica et Biophysica Acta - Biomembranes, v. 1788, n. 10, p. 2252-2258, 2009.

2) LOPES, JOSÉ LUIZ S.; MELO, HISSA, D.C.; V.M.M.; TONARELLI, G.; BELTRAMINI, L.M. Effect of Plantaricin149a and four analog peptides on Staphylococcus aureus ATCC 25923 and Pseudomonas aeruginosa ATCC 9027. Submetido à revista Peptides em Janeiro de 2010.

Um terceiro artigo, envolvendo os resultados decorrentes desta tese, encontra-se em fase de redação, e deverá ser submetido à publicação brevemente, trata-se de:

3) LOPES, JOSÉ LUIZ S.; NOBRE, T.M.; GÓMARA, M.J.; HARO, I.; TONARELLI, G.; BELTRAMINI, L.M. A single amino acid replacement modifies Plantaricin149 lytic action on biomembranes. 


\title{
Disruption of Saccharomyces cerevisiae by Plantaricin 149 and investigation of its mechanism of action with biomembrane model systems
}

\author{
José Luiz S. Lopes a , Thatyane M. Nobre a Álvaro Siano ${ }^{\text {b }}$, Verónica Humpola ${ }^{\text {b }}$, Nelma R.S. Bossolan ${ }^{\text {a }}$, \\ Maria. E.D. Zaniquelli ${ }^{c}$, Georgina Tonarelli ${ }^{\mathrm{b}}$, Leila M. Beltramini ${ }^{\mathrm{a}, *}$ \\ a Biofísica Molecular Sergio Mascarenhas, Instituto de Física de São Carlos, Universidade de São Paulo, São Carlos, SP, Brazil \\ b Depto. de Química Orgánica, Universidad Nacional del Litoral, Santa Fe, Argentina \\ c Laboratório de Físico-Química de Superfícies, FFCLRP, Universidade de São Paulo, SP, Brazil
}

\section{A R T I C L E I N F O}

\section{Article history:}

Received 5 May 2009

Received in revised form 18 June 2009

Accepted 29 June 2009

Available online 23 July 2009

\section{Keywords}

Antimicrobial peptide

Mechanism of antimicrobial activity

Peptide-lipid interaction

Surface elasticity

Saccharomyces cerevisiae inhibition

\begin{abstract}
A B S T R A C T
The action of a synthetic antimicrobial peptide analog of Plantaricin 149 (Pln149a) against Saccharomyces cerevisiae and its interaction with biomembrane model systems were investigated. Pln149a was shown to inhibit S. cerevisiae growth by more than $80 \%$ in YPD medium, causing morphological changes in the yeast wall and remaining active and resistant to the yeast proteases even after $24 \mathrm{~h}$ of incubation. Different membrane model systems and carbohydrates were employed to better describe the Pln149a interaction with cellular components using circular dichroism and fluorescence spectroscopies, adsorption kinetics and surface elasticity in Langmuir monolayers. These assays showed that Pln149a does not interact with either mono/polysaccharides or zwitterionic LUVs, but is strongly adsorbed to and incorporated into negatively charged surfaces, causing a conformational change in its secondary structure from random-coil to helix upon adsorption. From the concurrent analysis of Pln149a adsorption kinetics and dilatational surface elasticity data, we determined that $2.5 \mu \mathrm{M}$ is the critical concentration at which Pln149a will disrupt a negative DPPG monolayer. Furthermore, Pln149a exhibited a carpet-like mechanism of action, in which the peptide initially binds to the membrane, covering its surface and acquiring a helical structure that remains associated to the negatively charged phospholipids. After this electrostatic interaction, another peptide region causes a strain in the membrane, promoting its disruption.
\end{abstract}

(C) 2009 Elsevier B.V. All rights reserved.

\section{Introduction}

The huge increase in the number of antibiotic-resistant bacteria calls for the development of new compounds and classes of antimicrobial agents. Antimicrobial peptides (AMPs) are natural antimicrobial compounds that have been extensively studied and suggested as a potential tool for overcoming microbial resistance to conventional antibiotics. Particular attention has been given to their application in both the food industry [1,2] and pharmaceuticals [3], since AMPs seem to play important roles as natural food preservatives and as the first line of defense in many organisms [4].

Lactic acid bacteria produce a large variety of bacteriocins, proteinaceous compounds with bactericidal activity against a limited range of microorganisms $[5,6]$. These compounds are being extensively studied, since most of them are small molecules that can be easily obtained through chemical synthesis, and their applications have been widely tested [7].

\footnotetext{
* Corresponding author. Depto. Física e Informática, Instituto de Física de São Carlos, Universidade de São Paulo, Av. Trabalhador SaoCarlense, 400, São Carlos, SP, Brazil. Tel.: +5516 33739875; fax: +55 1633715381 .

E-mail address: leila@ifsc.usp.br (L.M. Beltramini).
}

Plantaricin 149 (Pln149), YSLQMGATAIKQVKKLFKKKGG, is a cationic antimicrobial peptide produced by Lactobacillus plantarum NRIC 149 [8] that has been identified as a bacteriocin and presents a narrow inhibitory spectrum that includes genera, species and subspecies of lactic acid bacteria. A synthetic C-terminal amide analog (Pln149a) [9] was shown to inhibit Listeria and Staphylococcus strains. Pln149a is also quite soluble in physiologic conditions and presented high yield in manual syntheses.

The interaction of antimicrobial peptides and cell membrane models is widely studied in the literature [10], and three different mechanisms of action have been established: barrel-stave, when the peptide recognizes the membrane and oligomerizes in order to form pores across the membrane; carpet, in which electrostatic interactions between the peptide and membrane result in local peptide accumulation, disrupting the cell membrane; and toroidal, which involves other membrane-dependent processes, such as translocation of cytotoxic peptides across the membrane [11].

Previous studies have described the inhibitory activity of Pln149a against Listeria and Staphylococcus strains and its interaction with AOT (sodium-bis-(2-ethylhexyl)-sulfosuccinate) reverse micelles as a model for cell membranes [9]. In the present work, these studies have been extended to elucidate the mechanism by which Pln149a 
carries out its activity in membrane system models and its action against a unicellular fungus, a different class of microorganism with a known cellular wall composition.

Based on the its vast usage in the food and pharmaceutical industries, Saccharomyces cerevisiae was selected as a yeast model to evaluate the inhibitory growth action of Pln149a and its ability to lyse the cellular wall. The lysis of yeast cellular walls has biotechnological applications in several areas, such as the preparation of protoplasts for genetic improvement in yeast, the treatment of cellular residual yeast mass from fermentation industries (particularly S. cerevisiae), the extraction of proteins, enzymes and pigments, the acquisition of functional carbohydrates from the cellular wall (glucan and mannan) and the preparation of animal ration. Generally, the lysis is done with enzymes and/or mechanical rupture of the cells. Neither process is very economical, since they demand high amounts of enzymes (lipolytic and glycolytic) and/or mechanical energy [12]. The possibility of using an antimicrobial peptide like Pln149a to increase the efficiency and to reduce the cost of this process offers new opportunities for the application of this peptide that was once expected to be a food-borne pathogenic antibacterial agent [9].

In this sense, this study also focuses on the growth inhibition promoted by Pln149a on S. cerevisiae cultures, using scanning electronic microscopy to check the peptide's action on the yeast. In parallel, a series of model systems were used to simulate the outer leaflet of cell membranes to investigate the interaction of Pln149a with different phospholipids in both monolayers and vesicles. Additionally, interactions with different membrane and cell wall components were also investigated with circular dichroism and fluorescence spectroscopies in order to observe the surface properties of the lipid-water interface and the structural changes of the peptide.

\section{Materials and methods}

\subsection{Materials}

Reagents and solvents used in synthesis, purification and measurements were P.A. grade. All phospholipids were purchased from Avanti Polar Lipids.

\subsection{Peptide synthesis and purification}

Plantaricin 149 analog (Pln149a) was manually synthesized on solid phase by Fmoc chemistry, using Rink Amide (4- $\left(2^{\prime}, 4^{\prime}-\right.$ dimethoxyphenyl-Fmoc-aminomethyl phenoxy) resin to prepare the C-terminal peptide amide. N-Fmoc-protected amino acids were from NovaBiochem. Couplings were performed by TBTU $\left[\mathrm{N}, \mathrm{N}, \mathrm{N}^{\prime}, \mathrm{N}^{\prime}-\right.$ Tetramethyl-O-(Benzotriazol-1-yl) Uronium Tetrafluoroborate], HOBT (N-Hydroxybenzotriazole) and DIPEA (N,N-Diisopropylethylamine); deblockings were done with piperidine $20 \%$ in DMF, and a mixture of TFA/TIS/EDT $/ \mathrm{H}_{2} \mathrm{O}$ (94: 2.5: 1: 2.5) ( $\left./ \mathrm{v}\right)$ was used for the final cleavage of the peptide from the resin. After $3 \mathrm{~h}$, the crude peptide was precipitated in cold diethyl ether, centrifuged and lyophilized. The peptide purification was carried out by dissolving the crude Pln149a ( $3 \mathrm{mg} / \mathrm{mL}$ ) in $\mathrm{H}_{2} \mathrm{O}(0.1 \% \mathrm{TFA})$ and performing a reverse phase chromatography on a YMC-Pack Polymer $C_{18}(250 \times 4.6 \mathrm{~mm}, 6 \mu \mathrm{m})$ column in an ÄKTA purifier system (GE Healthcare), monitoring absorbance at $220 \mathrm{~nm}$. The column was previously equilibrated with $\mathrm{H}_{2} \mathrm{O}$ (TFA $0.1 \%$ ) and eluted using a linear gradient from 0 to $70 \%$ of acetonitrile $90 \%$ in $\mathrm{H}_{2} \mathrm{O}$ (TFA $0.1 \%$ ) over $40 \mathrm{~min}$, at a $1 \mathrm{~mL} / \mathrm{min}$ flow rate.

\subsection{Liposome preparation}

Large unilamellar vesicles (LUVs) of 1,2-Dipalmitoyl-sn-Glycero-3[Phospho-rac-(1-glycerol)] (DPPG), 1,2-Dipalmitoyl-sn-Glycero-3[Phospho-L-Serine] (DPPS), 1,2-Dipalmitoyl-sn-Glycero-3-Phosphocholine (DPPC), 1,2-Dipalmitoyl-sn-Glycero-3-Phosphoethanolamine
(DPPE), 1,2-Dilauroyl-sn-Glycero-3-Phosphocholine (DLPC), 1,2Dimyristoyl-sn-Glycero-3-Phosphocholine (DMPC) and 1,2-Distearoylsn-Glycero-3-Phosphoethanolamine (DSPE) were prepared by dissolving each lipid in chloroform (except for DPPG, which was dissolved in a chloroform/methanol 4:1 (v/v) mixture), then the solvent was slowly evaporated under a $\mathrm{N}_{2}$ stream, yielding a dry lipid film that was subsequently submitted to a SpeedVac system for $2 \mathrm{~h}$. The dry lipids were hydrated in MilliQ water, then vortexed at temperatures above the gel/liquid-crystalline phase transition temperature of the phospholipids $\left(41^{\circ} \mathrm{C}, 41{ }^{\circ} \mathrm{C}, 63{ }^{\circ} \mathrm{C}, 54{ }^{\circ} \mathrm{C}, 2{ }^{\circ} \mathrm{C},-1{ }^{\circ} \mathrm{C}\right.$ and $74{ }^{\circ} \mathrm{C}$ for DPPG, DPPC, DPPE, DPPS, DMPC, DLPC and DSPE, respectively), and finally the multilamellar vesicles were extruded through a polycarbonate filter 11 times to yield LUVs with an average diameter of $100 \mathrm{~nm}$.

\subsection{Far-UV circular dichroism (CD) and secondary structural content of Pln149a}

The CD spectrum of Pln149a $(0.1 \mathrm{mg} / \mathrm{mL})$ in MilliQ water was recorded from 190 to $250 \mathrm{~nm}$ on a JASCO J-715 spectropolarimeter (Jasco Instruments, Tokyo, Japan) as an average of 16 scans, using a $0.1-\mathrm{cm}$ path length cylindrical quartz cuvette at $25^{\circ} \mathrm{C}$. The $\mathrm{CD}$ spectra of Pln149a incubated with each different LUV were also recorded under the conditions described above. Incubation was performed in a 1:20 peptide/lipid ratio.

The estimation of secondary structure elements in the peptide structure was performed by CD spectrum deconvolution using CDPro package [13], containing the ContinLL, Selcon3 and CDSSTR programs. Additionally, the formalism of Chen et al. [14] was used to estimate the helicoidal content $\left(f_{\text {helix }}\right)$ based on both the ellipticity at $222 \mathrm{~nm}$ $\left(\theta_{222} \mathrm{~nm}\right)$ and the number of amino acid residues $(n)$, as in Eq. (1):

$f_{\text {helix }}=\frac{\left[\theta_{222 \mathrm{~nm}}\right]}{-39,500 \cdot(1-2.57 / n)}$.

\subsection{Steady-state fluorescence}

The fluorescence emission spectra of Pln149a were obtained in an ISS K2 spectrofluorimeter (ISS Fluorescence, Analytical and Biomedical Instruments, Illinois, USA), at $25{ }^{\circ} \mathrm{C}$ using a circulating water bath (Fisher Scientific) around a $1-\mathrm{cm}$ path length rectangular quartz cuvette. Pln149a $(0.1 \mathrm{mg} / \mathrm{mL}$ in MilliQ water) was excited at $274 \mathrm{~nm}$ and the emission spectra were recorded from 290 to $450 \mathrm{~nm}$. Reference spectra were recorded and subtracted after each measurement.

\subsection{Surface tension and dilatational surface elasticity measurements}

The kinetics of Pln149a adsorption on DPPG monolayers were examined with surface tension measurements using the axisymmetric drop shape analysis method (OCA-20 from Dataphysics Instruments GmvH, Germany), with the oscillating drop accessory ODG-20, as previously described $[15,16]$. DPPG solution $(0.1 \mathrm{mM})$ was prepared in chloroform and methanol (4:1, v/v) and was gently spread on the surface of a Pln149a solution drop (from 0.125 to $8.25 \mu \mathrm{M}$ ) to generate a lipid monolayer. The drop was expanded up to $30 \mathrm{mN} \mathrm{m}^{-1}$, corresponding to biomembrane surface packing [17]. Subsequent changes in surface pressure due to peptide adsorption were plotted against time. The dynamic dilatational surface elasticity data were obtained after the surface tension reached equilibrium, using a periodic drop oscillation of $0.1 \mathrm{~mm}$ amplitude (relative area variation $\Delta A / A$ of $5.5 \%$ ) and $1.0 \mathrm{~Hz}$ frequency. The viscous effect (imaginary elasticity) of the surface elasticity was estimated from the phase angle. 


\subsection{Yeast growth inhibition assays}

Cultures of $S$. cerevisiae were grown overnight in yeast extract peptone dextrose medium (YEPD). Ten microliters of this saturated culture was used to inoculate $5 \mathrm{~mL}$ of YEPD medium in the presence of Pln149a $(80 \mu \mathrm{M})$. A control culture was grown in the absence of the peptide. Cultures were grown at $30{ }^{\circ} \mathrm{C}$ and $200 \mathrm{rpm}$; turbidity at $600 \mathrm{~nm}$ was monitored at 16 and $24 \mathrm{~h}$.

\subsection{Scanning electron microscopy (SEM)}

Cultures of $S$. cerevisiae were grown in YEPD culture medium in the presence and in the absence of Pln149a ( $1 \mathrm{mg} / \mathrm{mL})$. Different aliquots of these cultures were taken at 6,12 and $24 \mathrm{~h}$ of incubation and observed by SEM. Aliquots of the culture $(200 \mu \mathrm{L})$ were filtered through a cellulose-acetate membrane $(0.45 \mu \mathrm{m})$ that was washed with $0.9 \% \mathrm{NaCl}$ to remove sample excess, and further fixed in $2.5 \%$ glutaraldehyde for $12 \mathrm{~h}$, followed by washes with $100-\mathrm{mM}$ sodium phosphate ( $\mathrm{pH} 7.4$ ) and dehydration in a series of 50, 70, 80, 90, 95 and $100 \%$ ethanol. Critical point drying was promoted with HMDS (hexamethyldisilazane). Specimens on stubs were coated with gold and examined at $25 \mathrm{kV}$ in a Zeiss-DSM 960 scanning electron microscope (Oberkochen, Germany).

\section{Results and discussion}

\subsection{Pln149a synthesis and purification}

Peptide synthesis produces enough amounts of peptide to be used in the investigation of its mechanism of action and activity against microorganisms and biomembrane model systems.

After manual synthesis, the peptidyl-resin cleavage had an $85 \%$ yield of the crude peptide, according to the resin capacity. On the $\mathrm{C}_{18}$ purification, the major peptide fraction (78\% of the crude peptide) eluted at $38 \%$ of the acetonitrile gradient, as in Muller et al. [9], corresponding to purified Pln149a that was further used for structural characterization.

\subsection{Pln149a action against S. cerevisiae}

Pln149a was shown to inhibit S. cerevisiae growth by $82 \%$ in YPD medium for up to $16 \mathrm{~h}$, according to the turbidity decrease at $600 \mathrm{~nm}$ in comparison to control culture. Even after incubation for $24 \mathrm{~h}$, a $47 \%$ growth reduction was observed, showing that the peptide remained active and suggesting its probable resistance to the proteolytic action of yeast proteases present in the culture medium after $24 \mathrm{~h}$ of incubation.
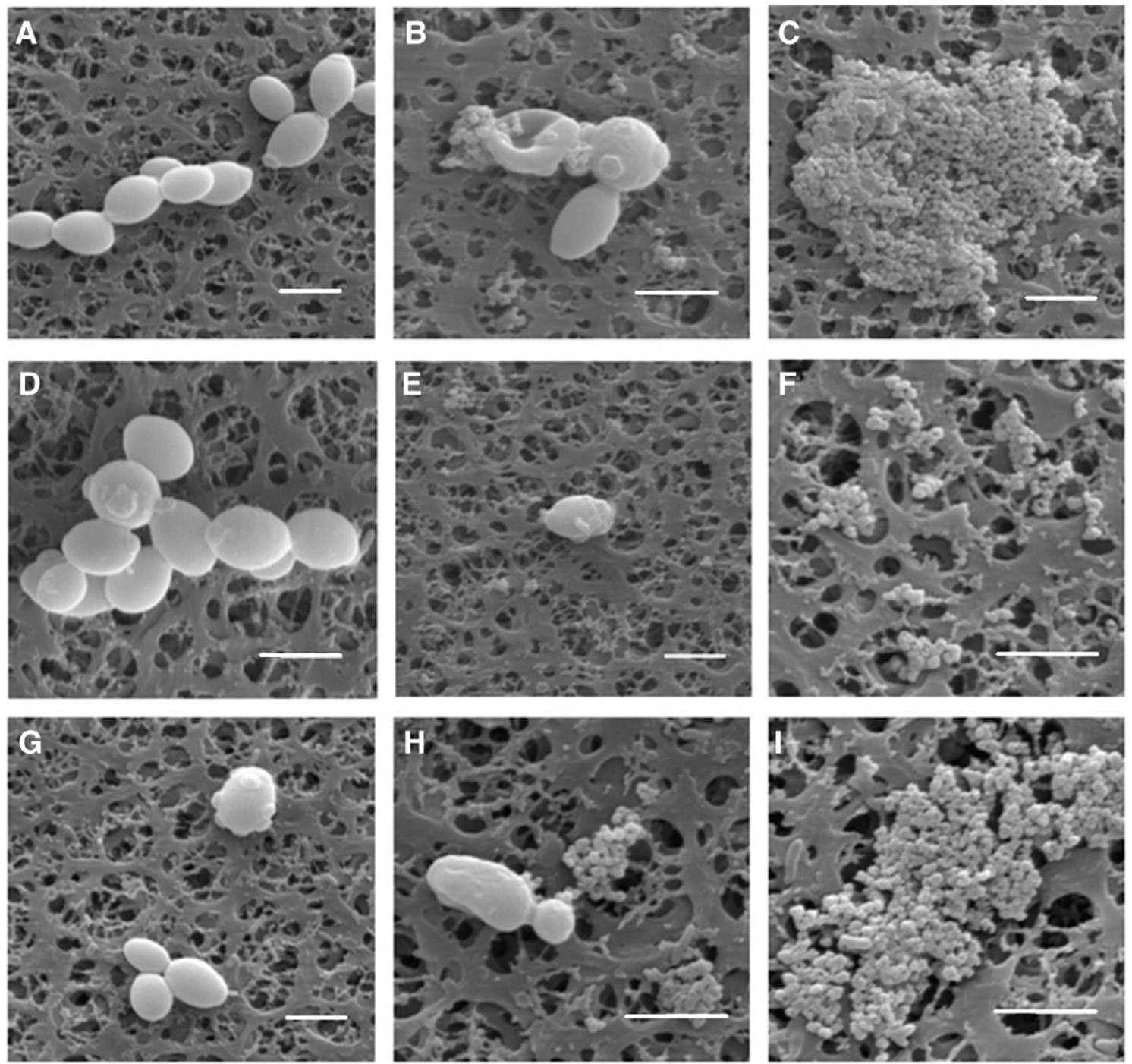

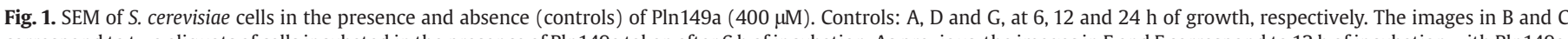

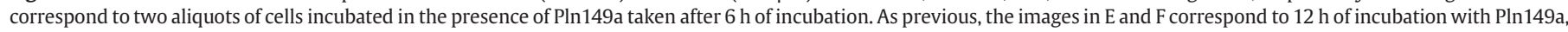
and images $\mathrm{H}$ and $\mathrm{I}$ correspond to $24 \mathrm{~h}$ of incubation. Bars $=5 \mu \mathrm{m}$. 
Fig. 1 presents SEM images of S. cerevisiae cultures exposed to Pln149a and also control cultures. The action on S. cerevisiae cells was observed over a period ranging from 6 to $24 \mathrm{~h}$ of incubation. Morphological changes in the yeast cell wall could be observed in the culture with Pln149a even after 6 h of exposure. Additionally, intact cells were rarely observed after $12 \mathrm{~h}$ of incubation, suggesting a strong action of the peptide against the yeast cells. However, although many antimicrobial peptides act at the cell membrane level [18], it remains unclear if this is the case for Pln149a. Also, it not known with which cellular component it interacts, since the mechanism through which many of the $\alpha$-helical antimicrobial peptides (AMPs) cause cell death does not involve binding to specific receptors [19].

The observed inhibition of $S$. cerevisiae growth created interest in studying the Pln149a mechanism of action, since the mechanism proposed for Pln149a on bacteria (carpet mechanism) [9] does not explain how Pln149a would act on yeast cell walls. The S. cerevisiae cell wall has external and internal layers constituted of three principal components: glucan, mannan and chitin [12], and the bacterial cell surface is composed of negatively charged components, such as lipopolysaccharide and teichoic acids. Thus, because the electrostatic interaction between cationic AMPs and the negatively charged bacterial cell surface should play an important role in their antibacterial activity [20], we first investigated Pln149a interaction with some mono- and polysaccharides that present similar properties to those of the S. cerevisiae cell wall.

\subsection{Circular dichroism}

No conformational changes in Pln149a CD spectra were observed when incubated with a neutrally charged galactomannan, a negatively charged carrageenan, or the neutral monosaccharide $\mathrm{N}$-acetylgalactosamine, which suggests that Pln149a does not interact with these polysaccharides or simple neutral monosaccharides (data not shown). Therefore, the peptide passes through the S. cerevisiae cell wall in a permeable way and interacts with the phospholipids from the plasma membrane, thus promoting a subsequent disruption of the yeast cell wall. Using different membrane models (constructed with the lipids DPPG, DPPC, DLPC, DMPC, DPPE, DSPE and DPPS), the interaction between Pln149a and the model systems has been investigated by $\mathrm{CD}$ and fluorescence spectroscopies.

Pln149a in aqueous medium shows an unordered structure in its CD spectrum (Fig. 2), with a minimum at $197 \mathrm{~nm}$ as well as many other small peptides in aqueous solution [21-23]. No conformational changes were seen for this spectrum when the peptide was observed in the presence of zwitterionic phosphocoline (DPPC) and phosphoethanolamine (DPPE) vesicles. Only in the presence of the negatively charged DPPG liposomes did Pln149a present differences in its native $\mathrm{CD}$ spectrum. This interaction induced conformational changes in the Pln149a secondary structure that are compatible with the presence of a helical element, assigned to the two negative minima at $222 \mathrm{~nm}$ and $208 \mathrm{~nm}$ and the positive maximum at $196 \mathrm{~nm}$. This result can be attributed to the negative surface of the DPPG vesicles, which provided a region where all the six basic Lys residues could be electrostatically stabilized, resulting in a strong interaction between them.

The interaction of Pln149a with the DPPS liposomes also produced no alterations in the peptide $C D$ spectrum, and it can be assumed that this phospholipid did not provide a suitable environment for the interaction of this cationic peptide. The negative regions of the serine group (the carboxylate-end and phosphate groups) had a negative surface density, decreased by the presence of the positive ammonium-end group located on the same serine of the same phosphate head.

Pln149a CD spectra in aqueous solution and in the presence of the different vesicles were used to estimate the percentage of helix structure, using a reference set of 43 proteins [13]. From the CD spectra deconvolution and quantification, the helical induction of Pln149a structure in the presence of DPPG vesicles was determined to be $16 \%$, with a $57 \%$ reduction of the unordered structure. This result agrees with that calculated from the formalism of Chen, where $18 \%$ helicity was estimated for Pln149a interacting with DPPG LUVs.

A coil-to-helix conformational change can also be seen in the structure of other antimicrobial peptides, either from amphibians [22, 24] or from bacteria, like Plantaricin A [10]. These are all positively charged peptides that undergo a helical induction when interacting with anionic species.

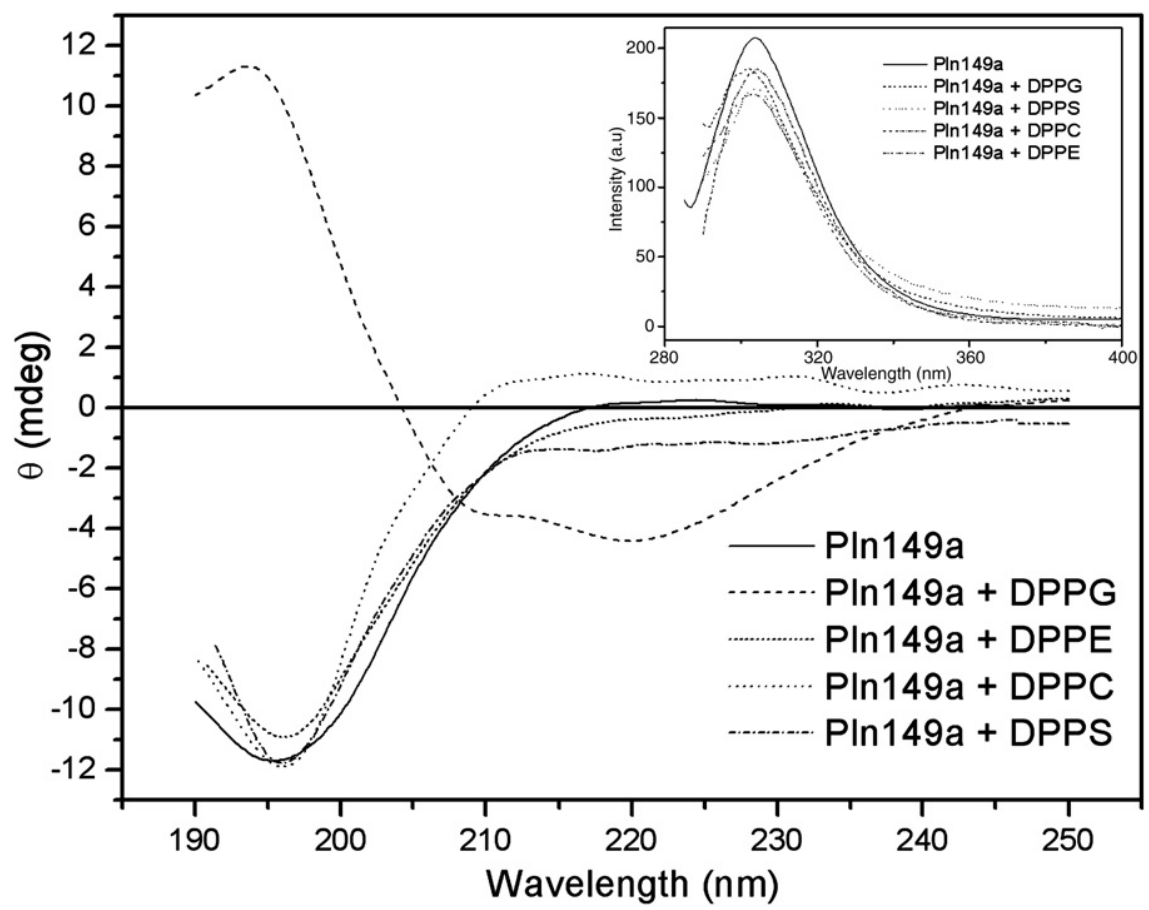

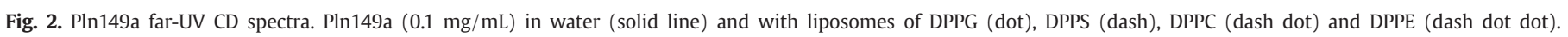
Measurements were taken from 190 to $250 \mathrm{~nm}$ as the average of 16 scans, at $25{ }^{\circ} \mathrm{C}$ and using a $0.1-\mathrm{cm}$ path length quartz cuvette. 
The cationic character of Pln149a and the formation of an amphipathic $\alpha$-helix structure when binding to negative phospholipids (like DPPG) have been shown to be compatible with the carpet mechanism, proposed by Shai [25], for linear amphipathic $\alpha$-helical peptides. The amphipathic helix generates a polar side with a positive net charge (due to Pln149a basic residues) that permits interactions with negative species, and a more apolar environment on the other helix side, where the hydrophobic residues of Pln149a can interact favorably with the membrane aliphatic chains.

The static fluorescence spectra of Pln149a measured after excitation at $275 \mathrm{~nm}$, in aqueous solution and in the presence of the vesicles, revealed the same $\lambda \max$ at $303 \mathrm{~nm}$ seen for Tyr residue emission when exposed to the aqueous phase [26], which can be attributed to the N-terminal position of this aromatic residue in the peptide. A small decrease in fluorescence intensity was observed in the presence of the phospholipid vesicles. Nevertheless, it was more likely due to quenching caused by changes in the chemical environment (from water to high density) than to the peptide interaction, since it was noted for all liposomes tested (Fig. 2 , inserted box).

\subsection{Surface activity}

From Fig. 3 it is apparent that Pln149a caused no surface tension $(\gamma)$ variation when spread on pure water subphase, even for the highest concentration studied, $8.12 \mu \mathrm{M}$. This means that the peptide did not present surface activity at the bare air-water interface in the concentration range studied here. However, the kinetics of adsorption of the peptide in the monolayer showed an induced surface activity promoted by the presence of DPPG (Fig. 3). Furthermore, the curves indicated a behavior dependent on the peptide concentration. From 0.125 to $2.06 \mu \mathrm{M}$, the adsorption kinetics presented similar behavior, accentuated by the increasing peptide concentration. The curves are characterized by a continuous decrease in the surface tension, but the trend expected for a diffusion mechanism and the equilibrium of adsorption are not reached in $500 \mathrm{~s}$. On the other hand, the curves corresponding to 4.12 and $8.25 \mu \mathrm{M}$ of Pln149a showed different behavior. Although the surface tension variation in the initial stages was faster than the result for smaller concentrations, a steady state $\left(\gamma_{\mathrm{eq}}\right)$ was apparently reached in these cases. Moreover, the $\gamma_{\mathrm{eq}}$ values were increased as much as the concentration. This behavior was not the one expected for a simple increase in the surface density with spread concentration, which should promote a higher decrease in surface tension. Thus, to better understand the interaction of Pln149a

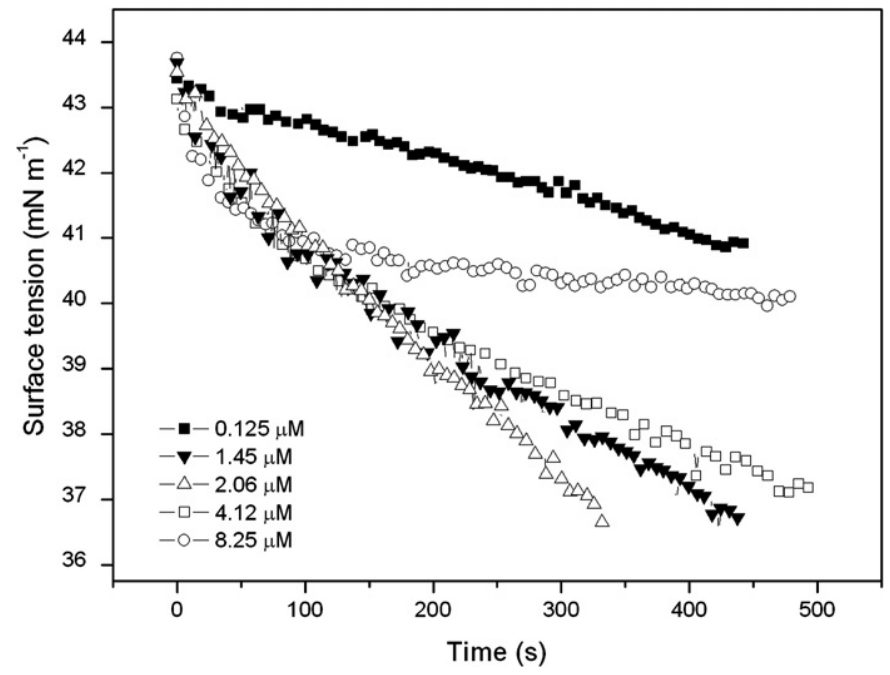

Fig. 3. Adsorption kinetics of Pln149a. Peptide concentration ranging from 0.125 to $8.25 \mu \mathrm{M}$ on DPPG monolayers.

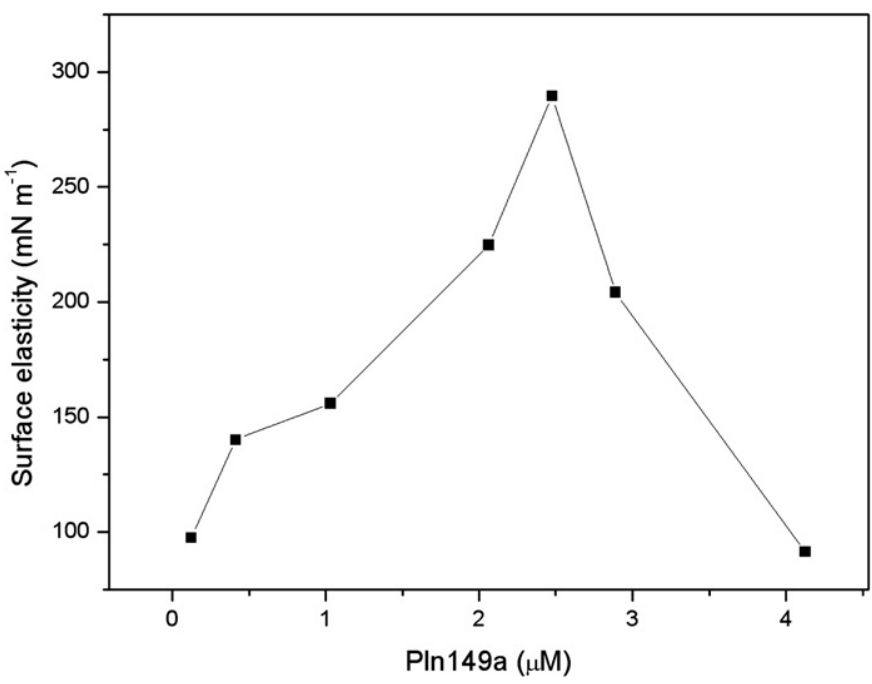

Fig. 4. Dilational surface elasticity for Pln149a/DPPG mixed monolayers. Measurements were taken at a frequency of $1 \mathrm{~Hz}$, relative area deformation of $5.5 \%$ and temperature of $25{ }^{\circ} \mathrm{C}$.

with the biomembrane model system, the DPPG monolayer, dilational surface elasticity $(E)$ measurements were performed.

Fig. 4 presents the $E$ data for DPPG monolayers in the presence of different Pln149a concentrations in the subphase. For pure lipid, the obtained $E$ value was $228.3 \mathrm{mN} \mathrm{m}^{-1}$. Thus Pln149a decreased the $E$ values, compared to DPPG monolayer formed at the air-water interface when present in concentrations below $2.06 \mu \mathrm{M}$. Similar results were observed for the AMP PGLa [27], where the structure and bending rigidity of DPPG monolayers formed at the liquid-liquid interface in the presence of the antimicrobial peptide were investigated and it was concluded that the peptide acts as a plasticizer for the membrane. However, the authors did not investigate the effect of peptide concentration for that system.

Coming back to Fig. 4, although for up to $1.65 \mu \mathrm{M}$ of Pln149a, $E$ increased only slightly and seemed to reach a plateau, a steep increase was observed above $2.5 \mu \mathrm{M}$. This change in behavior with concentration agrees with the adsorption kinetics data, for which a change was also reported above $2.06 \mu \mathrm{M}$. At $2.5 \mu \mathrm{M}$, a maximum was reached, surpassing the value for pure DPPG monolayer. After this point, an inversion in the behavior of the system was observed, and $E$ values started to decrease, indicating an increase in the fluidity of the model membrane.

Different studies in the literature have reported the effect of an antimicrobial peptide on membrane fluidity. It has been observed that oleuropein [28] expands different lipid monolayers, including polar lipids extracted from $E$. coli, suggesting that it is incorporated into the lipid monolayer. This assumption is corroborated by the surface elasticity data that presented lower values for the peptide. Another antimicrobial peptide, dicynthaurin [29], expands the DPPG monolayer because it accumulates on the monolayer. Furthermore, the presence of cynthaurin destabilizes the membrane model even at higher surface pressure values $\left(30 \mathrm{mN} \mathrm{m}^{-1}\right)$ [17], as confirmed by GIXD and epifluorescence microscopy, and the fluidization of the condensed chain lattice suggests that the peptide is able to expand the bacterial membrane, which would be relevant for the in vivo mode of action.

In Fig. 5, a model of the interaction between Pln149a and the DPPG monolayer, showing the induction of structural changes in the peptide structure, followed by the monolayer disruption is proposed. Firstly, the disordered structure-like peptide in bulk solution is electrostatic attracted to the charged phospholipids, promoting a peptide accumulation on the monolayer surface. The amphipathic peptide remains associated with the negatively phospholipids by its hydrophilic region 


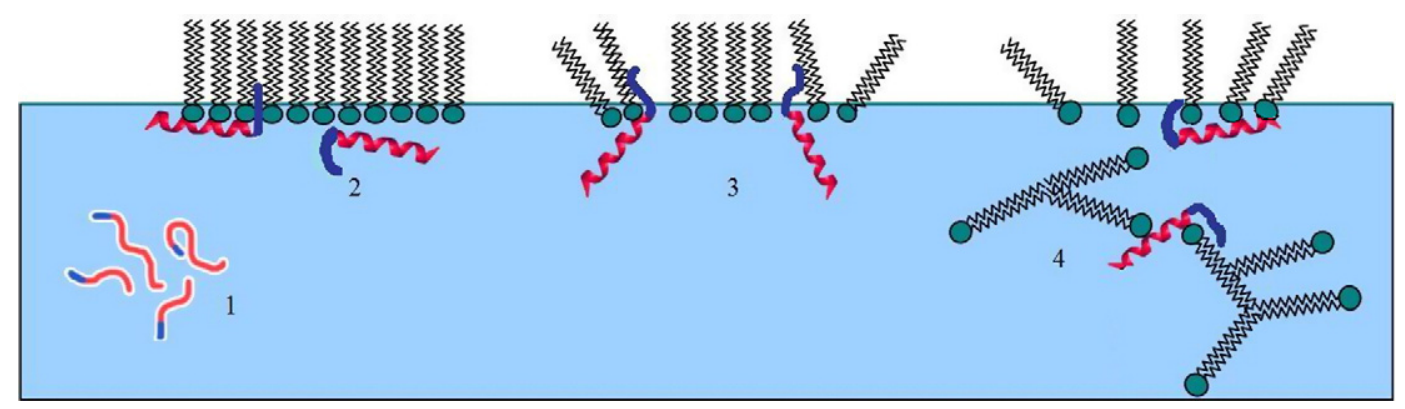

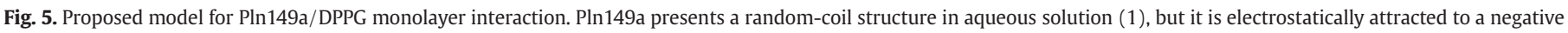

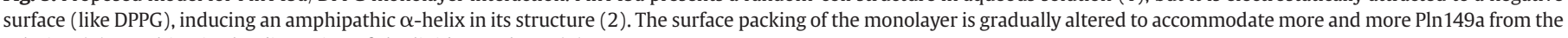
solution (3), resulting in the disruption of the lipid monolayer (4).

and, at the same time, the N-terminal residues (its more hydrophobic region) is inserted among the acyl chains of the phospholipids, altering the surface packing of the monolayer and promoting its disruption.

\section{Conclusions}

The observed action of Pln149a against S. cerevisiae suggests additional potential applications for this peptide in the food industry or as a non-enzymatic/non-mechanical process for disrupting cells.

Only the negatively charged DPPG was able to induce structural changes in Pln149a, as shown by the CD spectra changes recorded for DPPG LUVs in the presence of Pln149a. In contrast, the spectra recorded for the unordered Pln149a in solution and for liposomes prepared with DPPS, DPPE and DPPC were quite similar. Therefore, stabilization of the helix induced on PIn149a structure appears to be an important step of the "binding" that occurs by electrostatic interactions between the positively charged residues of the peptide and the anionic phospholipid heads. In addition, it can be assumed that the helical form imposed on the Pln149a structure is proportional to the driving forces that generate the attraction between these two species. That is, the interaction depends on both the electrical charge density of the phospholipids and the special features of Pln149a segments, such as the positive charge distribution and likelihood of hydrophobic portions being hidden inside the loops of the helix.

Analyzing the surface data, some important observations can be made about the mechanism of interaction between the peptide and the monolayer. Pln149a initially interacts with DPPG, adsorbing and accumulating at the lipid-air interface, as can be seen from the adsorption kinetics. This process becomes more effective as the concentration of peptide increases. On the other hand, the surface elasticity decreases, most likely because small amounts of peptide change the surface packing of the monolayer, resulting in a mixed and more fluid monolayer than that of pure DPPG. In fact, insertions of the peptide within the polar head group region should require space, disturbing the acyl chain packing.

However, increasing the peptide concentration produces a system with an elevated dilational elasticity modulus. This finding can only be explained if we assume that the manner in which the peptide interacts with the monolayer changes. If we examine the CD data for DPPG liposomes in the presence of Pln149a, we might assume that above a certain concentration the electrostatic interaction operates cooperatively, inducing a helix structure in the peptide that remains below the head groups, shielding the electrical charge of the negatively charged head groups and bringing them closer. This picture explains the elevated $E$ values measured for higher Pln149a concentrations. However, there is a limit for this kind of interaction, because above $2.5 \mu \mathrm{M}$ the steep decrease in $E$ is attributed to a disruption in the monolayer by a solubilization mechanism.

A similar mechanism probably takes place on the yeast cells (as observed in Fig. 1), in which the yeast membrane cell disruption leads away the wall cell disorganization, generating the aggregated (probably membrane and wall cells) and/or deformed cells (as in boxes $C, F$ and $G$ ).

In summary, all the results taken together have led us to conclude that Pln149a is an amphipathic $\alpha$-helical antimicrobial peptide that initially binds to the surface of negatively charged membranes, ultimately covering it in a carpet-like manner. Once the critical concentration of Pln149a is reached (close to $2.5 \mu \mathrm{M}$ ), the lipid layer is disrupted.

To better describe the mechanism of action of Pln149 in biologic membranes, its action against different classes of microorganisms, as well studies of other Pln149-derived peptides, with the aim of obtaining a peptide with potential activity are in current investigation in our group.

\section{Acknowledgments}

We are grateful for the financial support of the Brazilian agencies FAPESP and CNPq and the ANPCyT agency from Argentina.

\section{References}

[1] L. De Vuyst, E.J. Vandamme, Bacteriocins of lactic acid bacteria, Blackie Academic and Professional, London (1994) 409.

[2] B. Ray, M. Daesche, Food Biopreservatives of Microbial Origin, CRC Press, Boca Ratón, Florida, USA, 1992.

[3] M.A. Daw, F.R. Falkiner, Bacteriocins: nature, structure, functions, Micron. 27 (6) (1996) 467-479.

[4] H.G. Boman, Peptide antibiotics and their role in innate immunity, Annu. Rev. Immunol. 13 (1995) 61-92.

[5] J.R. Tagg, A.S. Dajani, L.W. Wannamaker, Bacteriocins of Gram-positive bacteria, Bacteriol. Rev. 40 (1976) 722-756.

[6] T.R. Klaenhammer, Bacteriocins of lactic acid bacteria, Biochimie 70 (1988) 337-349.

[7] L.L. Mackay, K.A. Baldwin, Applications for biotechnology: present and future improvements in lactic acid bacteria: a review, FEMS Microbiol. 87 (1990) 3-14.

[8] T. Kato, T. Matsuda, E. Ogawa, H. Ogawa, H. Kato, U. Doi, R. Nakamura, Plantaricin149, a bacteriocin produced by Lactobacillus plantarum NRIC 149, J. Fermentation Bioeng. 77 (3) (1994) 277-282.

[9] D.M. Müller, M.S. Carrasco, A.C. Simonetta, L.M. Beltramini, G.G. Tonarelli, A synthetic analog of plantaricin 149 inhibiting food-borne pathogenic bacteria: evidence for $\alpha$-helical conformation involved in bacteria-membrane interaction, J. Peptide Sci. 13 (3) (2007) 171-178.

[10] H. Zhao, R. Sood, A. Jutila, S. Bose, G. Fimland, J. Nissen-Meyer, P.K. Kinnunen, Interaction of the antimicrobial peptide pheromone Plantaricin A with model membranes: implications for a novel mechanism of action, Biochim. Biophys. Acta 1758 (9) (2006) 1461-1474.

[11] T.L. Orsolya, C. Lynette, S. Jacob, Peptide antibiotics in action: investigation of polypeptide chains in insoluble environments by rotational-echo double resonance, Biochim. Biophys. Acta 1758 (9) (2006) 1314-1329.

[12] J.B. Hunter, J.A. Asenjo, A structured mechanistic model of the kinetics of enzymatic lysis and disruption of yeast cells, Biotechnol. Bioeng. 31 (1988) 929-944.

[13] N. Sreerama, S.Y. Venyaminov, R.W. Woody, Estimation of protein secondary structure from circular dichroism spectra: inclusion of denatured proteins with native proteins in the analysis, Anal. Biochem. 287 (2) (2000) 243-251.

[14] Y.H. Chen, J.T. Yang, K.H. Chau, Determination of the helix and beta form of proteins in aqueous solution by circular dichroism, Biochemistry 13 (16) (1974) 3350-3359. 
[15] L. Caseli, D.C. Masui, R.P.M. Furriel, F.A. Leone, M.E.D. Zaniquelli, Adsorption kinetics and dilatational rheological studies for the soluble and anchored forms of alkaline phosphatase at the air/water interface, J. Braz. Chem. Soc. 16 (5) (2005) 969-977.

[16] T.M. Nobre, K. Wong, M.E.D. Zaniquelli, Equilibrium and dynamic aspects of dodecyltrimethylammonium bromide adsorption at the air/water interface in the presence of $\lambda$-carrageenan, J. Colloid Interface Sci. 305 (2007) 142-149.

[17] D. Marsh, Lateral pressure in biomembranes, Biochim. Biophys. Acta 1286 (1996) $183-223$.

[18] R. Maget-Dana, The monolayer technique: a potent tool for studying the interfacial properties of antimicrobial and membrane-lytic peptides and their interactions with lipid membranes, Biochim. Biophys. Acta 1462 (1999) 109-140.

[19] M.R. Yeaman, N.Y. Yount, Mechanisms of antimicrobial peptide action and resistance, Pharmacol. Rev. 55 (2003) 27-55.

[20] K. Matsuzaki, Why and how are peptide-lipid interactions utilized for selfdefense? Magainins and tachyplesins as archetypes, Biochim. Biophys. Acta 1462 (1999) 1-10.

[21] H. Sato, J.B. Feix, Peptide-membrane interactions and mechanisms of membrane destruction by amphipathic $\alpha$-helical antimicrobial peptides, Biochim. Biophys. Acta 1758 (2006) 1245-1256.

[22] J.RS.A. Leite, G.D. Brand, L.P. Silva, S.A.S. Kückelhaus, W.R.C. Bento, A.L.T. Araújo, G. R. Martins, A.M. Lazzari, C. Bloch Jr., Dermaseptins from Phyllomedusa oreades and
Phyllomedusa distincta: secondary structure, antimicrobial activity, and mammalian cell toxicity, Comp. Biochem. Physiol. A 151 (3) (2008) 336-343.

[23] Y.S. Koo, J.M. Kim, I.Y. Park, B.J. Yu, S.A. Jang, K.S. Kim, C.B. Park, J.H. Cho, S.C. Kim, Structure-activity relations of parasin I, a histone H2A-derived antimicrobial peptide, Peptides 29 (7) (2008) 1102-1108.

[24] M.S. Castro, T.C.G. Ferreira, E.M. Cilli, E. Crusca Jr., M.J.S. Mendes-Giannini, A Sebben, C.A.O. Ricart, M.V. Sousa, W. Fontes, Hylin a1, the first cytolytic peptide isolated from the arboreal South American frog Hypsiboas albopunctatus ("spotted treefrog"), Peptides 30 (2009) 291-296.

[25] Y. Shai, From innate immunity to de-novo designed antimicrobial peptides, Curr. Pharm. Des. 8 (2002) 715-725.

[26] J.R. Lakowicz, Principles of Fluorescence Spectroscopy 2 ed., Plenum Publishers, New York, 1999.

[27] E. Saint Martin, O. Konovalov, J. Daillant, Studies of phospholipid monolayer at liquid/liquid interface in presence of an antimicrobial peptide, Thin Solid Films 515 (2007) 5687-5690.

[28] J. Casas-Sanchez, M.A. Alsina, M.K. Herrlein, C. Mestres, Interaction between the antibacterial compound, oleuropein, and model membranes, Colloid Polym. Sci. 285 (2007) 1351-1360.

[29] M. Majerowicz, A.J. Waring, S. Wen, F. Bringezu, Interaction of the antimicrobial peptide dicynthaurin with membrane phospholipids at the air-liquid interface, J. Phys. Chem. B. 111 (2007) 382-3813. 


\section{Elsevier Editorial System(tm) for Peptides Manuscript Draft}

Manuscript Number:

Title: Effect of Plantaricin149a and four analog peptides on Staphylococcus aureus ATCC 25923 and Pseudomonas aeruginosa ATCC 9027

Article Type: Research Paper

Keywords: antimicrobial activity; antimicrobial peptide; circular dichroism, hemolytic assays

Corresponding Author: Prof. Dra. Leila Maria Beltramini, Ph.D

Corresponding Author's Institution: Universidade de Sao Paulo - IFSC

First Author: Jose Luiz S Lopes, PhD

Order of Authors: Jose Luiz S Lopes, PhD; Denise C Hissa; Vania M Mello; Georgina Tonarelli, Ph.D; Leila Maria Beltramini, Ph.D

Abstract: Plantaricin149 is a linear cationic antimicrobial peptide that interacts with negatively charged phospholipids from cell membrane and promotes the disruption of these organized structures. In this study, four Pln149 analogs modified at their N-terminal were synthesized, the hemolytic effect on red blood cells and antibacterial activity against microorganisms were evaluated and their interaction with liposomes was studied. All the four analogs showed Pln149a like behavior, with the induction of a helical element when binding to negative liposomes, however, with a lower helical content. The $\mathrm{N}$-terminal distinction between these analogs and Pln149a resulted in a different mechanism of action, that was bactericidal to the latter and bacteriostatic to the former, but remained the antibacterial effect against S. aureus and P. aeruginosa for all peptides, with MIC50 values of $19 \mathrm{uM}$ and $155 \mathrm{uM}$, to Pln149a, respectively. In addition, three of the peptides presented no hemolytic effect (less than 5\%) up to the concentration of $0.5 \mathrm{mM}$. The results suggest the lytic activity of Pln149a and its lethal effect on these microorganisms is achieved by contributions from the two regions of the peptide: the ionic contacts of the polar helix, and also the hydrophobic interactions of the apolar residues at the $\mathrm{N}$-terminal.

Suggested Reviewers: Isabel Haro PhD

Department of Peptide \& Protein Chemistry, Spain,, CSIC - IQAC

ihvqpp@iiqab.csic.es

Roger Leblanc PhD

Chemistry Department, University of Miami

rml@miami.edu

Eduardo Maffud Cilli PhD

Departament of Biochemistry, Institute of Chemistry - UNESP

cilli@iq.unesp.br

Antimicrobial Peptide Synthesis and Studies

Opposed Reviewers: 



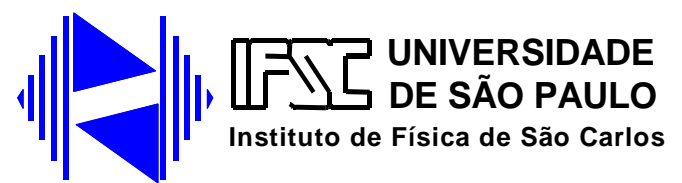

Departamento de Física e Informática

Grupo de Biofísica Molecular Sérgio Mascarenhas

PO Box 369, 13560-970 - São Carlos, SP, BR.

Tel: 5516 3373-9875 Tel/Fax : 5516 3371-5381
CBME

Centro de

Biotecnologia

Molecular Estrutural

http://cbme.if.sc.usp.br

São Carlos, 01/19/2010

Dr. Abba J. Kastin

Editor-in-Chief - Peptides

Pennington Biomedical Research Center

Baton Rouge, LA 70808-4124, USA

Dear Dr. Kastin,

Please find enclosed the electronic file of the manuscript "Effect of Plantaricin149a and four analog peptides on Staphylococcus aureus ATCC 25923 and Pseudomonas aeruginosa ATCC 9027" which describes the antimicrobial activity of the peptide Plantaricina 149 and four modified analogs against pathogenic bacteria cells and their interaction with biomimetic systems. We would like it to be considered for publication in Peptides as a regular paper.

Sincerely Yours,

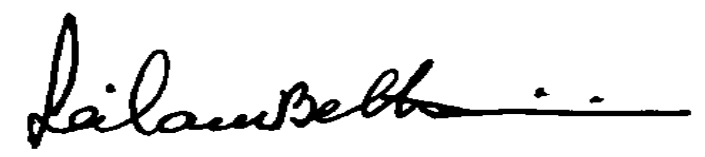

Prof. Leila Maria Beltramini, PhD.

Corresponding author

Instituto de Física de São Carlos - USP

Grupo de Biofísica Molecular "Sérgio Mascarenhas"

Av. Trabalhador São Carlense, 400

Cx. Postal 369 - São Carlos - São Paulo - Brasil

CEP 13560-970

Phone/fax: 55 (16) 3371-5381

leila@if.sc.usp.br 
1

2

3

\section{Effect of Plantaricin149a and four analog peptides on Staphylococcus aureus ATCC 25923 and Pseudomonas aeruginosa ATCC 9027}

José L.S. Lopes ${ }^{\text {a }}$; Denise C. Hissa ${ }^{\text {; }}$ Vânia M.M. Melo ${ }^{\text {b }}$ Georgina Tonarelli ; Leila M.

$$
\text { Beltramini }^{\text {a,* }}
$$

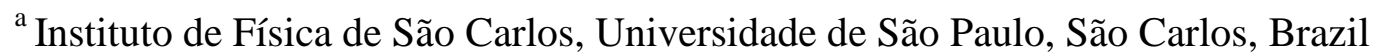

${ }^{\mathrm{b}}$ Depto. Biologia, Universidade Federal do Ceará, Fortaleza, Brazil

${ }^{c}$ Depto. Química Orgánica, Universidad Nacional del Litoral, Santa Fé, Argentina

* Corresponding author: Prof. Dra. Leila Maria Beltramini

Depto. Física e Informática - Grupo de Biofísica Molecular "Sérgio Mascarenhas"

Instituto de Física de São Carlos - Universidade de São Paulo

Av. Trabalhador São-carlense, 400, São Carlos, SP, Brazil

Phone: +55-16-33739875. Fax: +55-16-33715381

leila@ifsc.usp.br

Keywords: antimicrobial activity; antimicrobial peptide; circular dichroism, hemolytic assays 


\begin{abstract}
Plantaricin149 is a linear cationic antimicrobial peptide that interacts with negatively charged phospholipids from cell membrane and promotes the disruption of these organized structures. In this study, four Pln149 analogs modified at their N-terminal were synthesized, the hemolytic effect on red blood cells and antibacterial activity against microorganisms were evaluated and their interaction with liposomes was studied. All the four analogs showed Pln149a like behavior, with the induction of a helical element when binding to negative liposomes, however, with a lower helical content. The N-terminal distinction between these analogs and Pln149a resulted in a different mechanism of action, that was bactericidal to the latter and bacteriostatic to the former, but remained the antibacterial effect against $S$. aureus and $P$. aeruginosa for all peptides, with $\mathrm{MIC}_{50}$ values of $19 \mu \mathrm{M}$ and $155 \mu \mathrm{M}$, to Pln149a, respectively. In addition, three of the peptides presented no hemolytic effect (less than 5\%) up to the concentration of $0.5 \mathrm{mM}$. The results suggest the lytic activity of Pln149a and its lethal effect on these microorganisms is achieved by contributions from the two regions of the peptide: the ionic contacts of the polar helix, and also the hydrophobic interactions of the apolar residues at the N-terminal.
\end{abstract}

\title{
1. Introduction
}

The advent of multidrug resistance bacteria has led to the employment of two or more of the available antibiotics in association with resistant strains [1]. As an alternative to this process [2], antimicrobial peptides were shown to maximize their inhibitory activity to pathogenic microorganisms by the insertion of different modifications on their primary 
structure, like amidation, ciclation and insertion of non-proteic groups on their N-terminals $[3,4]$.

Plantaricin 149 (Pln149, YSLQMGATAIKQVKKLFKKKGG) is a naturally occurring 22-amino acid peptide, isolated from Lactobacillus plantarum NRIC149 [5]. Its amidated analog, Pln149a, is a positively charged linear peptide that presents a narrow spectrum towards Staphylococcus aureus and Listeria monocytogenes and undergoes a helicoidal induction on its secondary structure in an apolar environment or when it interacts with negative biomembranes. In addition, it was also established the action of Pln149a against Saccharomyces cerevisae, showing that the peptide causes morphological changes on the yeast cell, due to its interaction with the membrane cell and subsequent disruption $[6,7]$.

The mechanism of action proposed to Pln149a was the electrostatic attraction of the disordered structure-like peptide in bulk solution to the charged phospholipids, that induces an amphipathic $\alpha$-helix on the peptide structure and promotes its accumulation on the phospholipid surface. The amphipathic helix stretches from residue Ala7 to Lys20, creating a polar side with 5 Lys residues that enables interactions, and an apolar side, due to its hydrophobic residues (Tyr, Leu, Ile, Met, Ala) at the N-terminal that lead the Van de Waals contributions. At this stage, it was suggested that the peptide must remain associated with the negatively phospholipids while its N-terminal residues are inserted on the phospholipids acyl chains, it gradually alters the surface packing of the lipid layer and resulting in the membrane disruption [7]. However, the assumption that the N-terminal of Pln149a also plays a role in the disruption of the membranes must be better explored.

According to this mechanism, one can think that the positive region of Pln149a itself is likely to trigger its antibacterial activity, since the helix stabilization represents a 
fundamental/essential step for the binding. Tonarelli, G., in personal communication, observed that the pentapeptide YSLQM from the N-terminal portion of Pln149 does not present antibacterial properties. In the present work, four novel Pln149a analogs modified at their N-Terminal were synthesized, their antimicrobial and hemolytic activities and the interactions with biomembrane models were investigated. The results showed that the four analogs presented inhibitory activity against Pseudomonas aeruginosa and Staphylococcus aureus growth but with a different mechanism that presented by Pln149a.

\section{Materials and methods}

2.1. Materials - Chemicals were purchased from Sigma-Aldrich (St. Louis, USA), unless stated. All protected amino acids, coupling reagents and polymers were obtained from NovaBiochem (San Diego, USA). Solvents were of P.A. grade and buffers were prepared in MilliQ water and filtered in $0.2 \mu \mathrm{m}$ polycarbonate membranes.

2.2. Peptide Synthesis and Purification - Pln149a was synthesized by Fmoc strategy and purified by Reverse Phase Chromatography as described elsewhere [7]. The four novel Pln149-analogs were synthesized by the same protocol and with the same amino acid sequence as Pln149a, but reducing the peptide size by starting with the Gly at position 6 and ending with the Gly at position 22 (GATAIKQVKKLFKKKGG). Besides the 17amino acid peptide, three other $\mathrm{N}$-terminal modified peptides were synthesized: the first with a simple monosaccharide (acetyl group); the second one with a hydrocarbon chain (Noctyl group); and the last one with a Fmoc group at the N-terminal amino acid residue. The 
four Pln149-analogs were named as Pln149(6-22), Ac-Pln149(6-22), Noctyl-Pln149(6-22) and Fmoc-Pln149(6-22), respectively.

Aliquots of each analog peptide were purified using a GE ÄKTA Purifier System (GE Healthcare) with an YMC-Pack Polimer $\mathrm{C}_{18}$ column $(250$ x $4.6 \mathrm{~mm}, 6 \mu \mathrm{m}$ bead size, Waters, Germany) equilibrated with $0.1 \%$ (v/v) TFA/water (solvent A). Elution was performed at a $1 \mathrm{ml} / \mathrm{min}$ flow rate using a two-step gradient: initially, from $0 \%$ to $70 \%$ solvent B (acetonitrile 90\% in water containing 0.1\% TFA) over $40 \mathrm{~min}$, followed by 70 $100 \%$ of the same solvent over $1 \mathrm{~min}$. Absorbance was monitored at $220 \mathrm{~nm}$. The corresponding fractions of each peptide were collected and lyophilized.

2.3. Peptide Characterization - Mass Spectrometry analyses were performed with Pln149a and all the four derived peptides on an ESI-MS Spectrometer (Micromass, Manchester, UK). Aliquots of each peptide were diluted into a $60 \%$ methanol aqueous solution with $5 \%$ formic acid and directly injected in the spectrometer. Experiments were performed by scanning from a 1000 to $2000 \mathrm{~m} / \mathrm{z}$ ratio.

To check the sequence of synthesis, the primary structure determination of purified Pln149(6-22) was performed by automated Edman degradation on an automatic protein sequencer PPSQ-23A Shimadzu (Kyoto, Japan): Aliquots (200 pmol) of each peptide in $\mathrm{H}_{2} \mathrm{O}$ and Sequa-Brene (hexadimethrine bromide) were applied on a special fiber-glass disk (Wako, Osaka, Japan), previously treated with Sequa-Brene.

2.4. Circular dichroism (CD) analysis - The CD spectra of Pln149a and analog peptides were recorded on a Jasco J-815 CD spectrometer (Tokyo, Japan) from 190 to $250 \mathrm{~nm}$ using 
a $0.1 \mathrm{~cm}$ path length rectangular quartz cuvette, at $25^{\circ} \mathrm{C}$. For each spectrum, the data from eight scans were averaged and the reference spectrum was subtracted. Peptides were diluted in MilliQ water $(0.15 \mathrm{mg} / \mathrm{mL})$ and also in the presence of $1 \mathrm{mM}$ DPPG (dipalmitoyl phosphatidyl glycerol), a negatively charged vesicle prepared as described elsewhere [7].

2.5. Hemolytic activity against human erythrocytes - The present method was based on Tsubery et al. [8]. Briefly, freshly collected human blood of healthy donors was collected and red cells were separated from the plasma by sedimentation, washed three times with PBS (pH 7.4) containing $0.15 \mathrm{M} \mathrm{NaCl}$. Aliquots $(100 \mu \mathrm{L})$ of $1 \%(\mathrm{v} / \mathrm{v})$ suspension erythrocytes were employed to determine the hemolytic effect of Pln149a and Pln149analog peptides in serial dilutions (from 1 to $500 \mu \mathrm{M}$ ). Samples were incubated for $1 \mathrm{~h}$ at $37^{\circ} \mathrm{C}$, centrifuged at $3000 \mathrm{~g}$ and aliquots of supernatant were transferred to a 96-well microplate and evaluated spectrophotometrically at $405 \mathrm{~nm}$ to monitor the release of hemoglobin. Triton X-100 was used as control of $100 \%$ hemolysis and for no hemolisis a PBS solution was used. The hemolysis percentage was calculated using the equation (1):

$$
\%_{\text {hemolisis }}=\frac{\left[A_{\text {Peptide }}-A_{P B S}\right]}{\left[A_{\text {Triton }}-A_{P B S}\right]} \quad \text { equation (1). }
$$

2.6. Antibacterial activity and MIC Determination - Two different assays were employed to investigate Pln149a and analogs antibacterial activity. In the first one, the method of diffusion in agar plates [Bauer et al, 1966] was assayed with Bacillus subtilis ATCC 6633, Enterobacter aerogenes ATCC 13048, Klebisiella pneumonia ATCC 10031, Pseudomonas aeruginosa ATCC 9027, Staphylococcus aureus ATCC 25923, Salmonella choleraesius ATCC 10708, Staphylococcus aureus ATCC 6538, Pichia membranaefaciens, Candida 
tropicalis, Candida albicans 14053, Candida crusei 6258, Lactobacillus sp L1, Lactobacillus sp L9, Lactobacillus sp L15, and Lactobacillus sp L18. Microorganism suspensions in $\mathrm{NaCl} 0.85 \%$ with their absorbance in $600 \mathrm{~nm}$ adjusted to $0.100\left(10^{7}\right.$ UFC/mL) were homogeneously spread on Petri plates with solid culture medium. Aliquots $(15 \mu \mathrm{L})$ of Pln149a $(1 \mathrm{mg} / \mathrm{mL})$ were deposited on discs of paper placed on the plate surface. Plates were incubated at $38^{\circ} \mathrm{C}$ for $24 \mathrm{~h}$. Growth inhibition was evaluated by the formation of inhibition halo around the discs. Additionally, two discs were employed on each plate as controls: a negative one, with antibiotic tetraciclin (TET30), and a positive one, with sterile MilliQ water. The solid culture media used were Lactobacilli to the lactic acid bacteria, Sabouraud to the yeasts, and Mueller Hinton to the bacteria. All these strains were provided by the Microbial Ecology and Biotechnology Lab from Universidade Federal do Ceará, Brazil.

In the second type of experiment, microtiter broth growth inhibition assays were conducted with the reference strains of Staphylococcus aureus (ATCC 25923) and Pseudomonas aeruginosa (ATCC 9027), based on the method described by Hancock [ref Hancock, 1999], with some modifications. The pathogenic bacteria were firstly grown in Mueller-Hinton broth $(5 \mathrm{~mL})$ at $37^{\circ} \mathrm{C}$. When $\mathrm{OD}_{600 \mathrm{~nm}}$ reached 1.0 , the bacterial suspension was diluted in fresh Mueller-Hinton broth and adjusted to $\mathrm{OD}_{600 \mathrm{~nm}} 0.010\left(10^{6} \mathrm{UFC} / \mathrm{mL}\right)$. Growth inhibition assays were carried out by adding sterile Pln149a (100 $\mu \mathrm{L})$ and each of the four derived peptides in PBS (pH 7.4) to a 96-well microtitter plate. Serial dilutions of the peptides (from 620 to $1.2 \mu \mathrm{M}$ ) were incubated with the diluted bacterial suspension 1:1 (v/v) in Mueller-Hinton broth. A positive control was used to incubate the bacterial suspension with PBS and a negative control containing $0.4 \%$ (v/v) formaldehyde. Each 
microplate was incubated for $24 \mathrm{~h}$, at $37^{\circ} \mathrm{C}$ and growth inhibition was analyzed at $600 \mathrm{~nm}$ on a Microplate TP-reader (Thermoplate). Minimal inhibitory concentration $\left(\mathrm{MIC}_{50}\right)$ was considered the lowest concentration that inhibits $50 \%$ bacterial growth. All experiments were performed in duplicate.

Additionally, to verify if the peptides action was either bactericidal or bacteristactic, aliquots $(5 \mu \mathrm{L})$ of each well from the microplate were subcultived in a Petri plate with Mueller-Hinton agar. The plates were incubated at $37^{\circ} \mathrm{C}$ for $24 \mathrm{~h}$ and growth was visually detected.

\section{Results}

\subsection{Peptide synthesis, purification and characterization}

Pln149a and other four analog peptides were synthesized by solid phase method using Fmoc chemistry. A manual synthesis was successfully performed to yield a polypeptide chain corresponding to Pln149 from residue 6 to 22. At this step, the peptidyl-resin was equally subdivided in four parts to generate each Pln149 reduced analog. The first one was cleaved from the resin with no N-terminal insertions, resulting in the analog Pln149(6-22). Three different groups were attached to the N-terminal residue of peptidyl-resin: an acetyl, a N-octyl, and a hydrophobic moiety Fmoc, resulting in the three Pln149 analogs with Nterminal modifications: Ac-Pln149(6-22), Noctyl-Pln149(6-22) and Fmoc-Pln149(6-22), respectively. The sequence, name, and molecular mass of each analog are in Table 1.

The four modified peptides were purified to homogeneity (>98\%) by HPLC. The purification chromatogram profile, showed in Figure 1 (inserts), revealed the efficiency of manual synthesis due to the majoritary peak of each analog and the increase in 
hydrophobicity in the peptides, in wich the analog Pln149(6-22) was eluted at $32 \%$ of $\mathrm{ACN}$, and the other-analogs containing the acetyl, the N-octyl and the Fmoc groups were eluted at positions corresponding to a $43.5,55$, and $58.7 \%$ of $\mathrm{ACN}$, respectively.

The molecular weight of each analog was determined by electrospray mass spectrometry, as shown in Figure 1. The peptides Pln149(6-22), Ac-Pln149(6-22), NoctylPln149(6-22), and Fmoc-Pln149(6-22) presented the following masses 1801, 1843, 1928, and $2024 \mathrm{Da}$, respectively. The correct amino acid sequences were checked by Edman degradation.

\subsection{Circular dichroism (CD) studies}

The shape of CD spectra of all analogs in water was similar to Pln149a [7] and many other linear antimicrobial peptides in aqueous solution [3, 8-10]., showed in Figure 2A. These spectra are typical of disordered secondary structure with minima centered on 198 $\mathrm{nm}$.

Pln149a showed a significant conformational change in the presence of negatively charged biomembrane models (like DPPG vesicles), inducing a helical element on its secondary structure and presenting minima at 222 and $208 \mathrm{~nm}$ and a maximum centered at $196 \mathrm{~nm}$ [7]. The CD spectra of all four analogs were measured when incubated with this negatively charged vesicle, showing the helical conformation as observed to Pln149a, (Figure 2B), and helical antimicrobial peptides [11-13]. However, the helical content induced on these analogs was lower than the observed to Pln149a, indicated by the lower intensity of the band at $222 \mathrm{~nm}$, confirmed by deconvolution with CDPro Package [14].

\subsection{Hemolytic assay}


In this assay, hemolysis was visually detected in positive control right after the addition of $1 \%(\mathrm{v} / \mathrm{v})$ Triton $\mathrm{X}-100$, while sedimentation was observed in the negative control (PBS). Cell sedimentation was also observed in wells corresponding to the Pln149 analogs in the range from 1 to $500 \mu \mathrm{M}$, indicating no hemolytic activity (less than $5 \%$ ) for Pln149(6-22), Ac-Pln149(6-22), and Noctyl-Pln149(6-22), data not shown. The analog Fmoc-Pln149(6-22) presented different behavior: weak hemolytic activity was observed at concentrations below $125 \mu \mathrm{M}$, however, at 250 and $500 \mu \mathrm{M}$, a red solution was observed, indicating 12 and $24.4 \%$ hemolysis, respectively.

\subsection{Antibacterial assay}

The inhibition assay by diffusion on agar plates method was not effective to evaluate Pln149a antimicrobial activity, since no inhibition halo was observed in all strains tested. AMPs can present different diffusion in some culture media, with a medium-dependent antimicrobial activity (MIC) that is generally bigger than the observed in a different medium $[15,16]$. This can be attributed to the decrease of the peptides diffusion coefficient on the medium.

The antibacterial activity of Pln149a and the four N-terminal modified peptides were also directly assessed against Staphylococcus aureus ATCC 25923, and Pseudomonas aeruginosa ATCC 9027, as summarized in Figure 3.

Pln149a showed stronger antimicrobial activities against Staphylococcus. aureus. No bacterial growth was observed in the presence of Pln149a from 78 to $620 \mu \mathrm{M}$. The peptides $\mathrm{MIC}_{50}$ against pathogenic Staphylococcus aureus ATCC 25923 were: Pln149a $19 \mu \mathrm{M}$, Pln149(6-22) $78 \mu \mathrm{M}$, Ac-Pln149(6-22) $78 \mu \mathrm{M}$, Noctyl-Pln149(6-22) $38 \mu \mathrm{M}$, and Fmoc- 
Pln149(6-22) $10 \mu \mathrm{M}$. The $\mathrm{MIC}_{50}$ against $P$. aeruginosa were of $155 \mu \mathrm{M}$ for Pln149a, Pln149(6-22), Ac-Pln149(6-22), and Noctil-Pln149(6-22), and of 19 for Fmoc-Pln149(622), respectively. The inhibitory concentrations where no bacterial growth observed for $P$. aeruginosa were higher than $310 \mu \mathrm{M}$.

Pln149a was proved to be lethal for these two microorganisms, none of the aliquots where inhibition was noted from assay with both strains were capable of resuming growth on agar plates in medium in the absence of Pln149a after $24 \mathrm{~h}$ incubation due to its bactericidal action. However, the four analogs presented a different mechanism of action, promoting a basteriostatic inhibition against $S$. aureus and $P$. aeruginosa in most of the wells where growth inhibition was detected.

\section{Discussion}

In the present study, we have reported the synthesis, purification, and hemolytic properties of four analog peptides of Plantaricin149, and compared their antimicrobial properties with the previously described analog peptide Pln149a.

The analogs Ac-Pln149(6-22), Noctyl-Pln149(6-22), and Fmoc-Pln149(6-22) presented an increase in hydrofobicity compared to Pln149(6-22), that is due to the apolar character in their N-terminal parts. Despite the increase of apolarity, three of these Nterminal modified peptides remained with low level of hemolytic activity. The weak hemolytic effect of Pln149a and analogs in front of the red cell membranes is in agreement with the lack of specificity/binding of Pln149a to zwitterionic phospholipids vesicles. Only the most apolar analog, Fmoc-Pln149(6-22), presented-hemolytic property in concentration higher than $250 \mu \mathrm{M}$. 
The typical conformational CD change from random structure to helical element, observed in the analogs, showed that the electrostatic attraction and the helix stabilization step in the binding of this antimicrobial peptide to the liposomes does still remain on these analog peptides. However, the reduction of Pln149a size, by the removal of its first $5 \mathrm{~N}-$ terminal residues has created a slightly less appropriated molecule to interact with the liposomes, reducing the magnitude of the helical content formed during the binding.

The N-terminal modifications have neither caused severe perturbations on the peptide structure, nor hindered the interaction of these peptides with negative biomembranes. Furthermore, the increment in the antimicrobial activity of the Fmoc-derived peptide was due to the lytic effect induced by this hydrophobic group, as seen at hemolytic assay. The inability of the other N-terminal modifications to alter the peptide activity suggests that replacing the $\mathrm{N}$-terminal region of $\mathrm{P} \ln 149 \mathrm{a}$ for prostetic groups (acetyl and $\mathrm{N}$-octyl) could not completely fulfill the requirements for the lytic properties of Pln149a that is associated to the apolar residues at this region of peptide.

Pln149a antimicrobial activity showed to be more effective against Gram-positive bacteria, a feature that is shared with many amphibian antimicrobial peptides [17] that present lowest MIC values to Staphylococcus, Listeria. The difference in the bacteriocidal/bacteriostatic mechanism of action of Pln149a and Pln149(6-22) can be attributed to the lack of the N-terminal portion in the latter, since this region must be the responsible for the peptide penetration between the phospholipid acyl chains. Besides, all the other analogs presented lower MICs values than Pln149a, confirming the importance of the contribution from the N-terminal segment to Pln149 lytic activity at biologic membranes. 


\section{Acknowledgments}

We are grateful to Prof. H.S.S. Araújo and Prof. J.C. Rosa for primary structure sequencing and mass spectroscopy analysis, respectively. This work was supported by FAPESP (CEPID program), and in part by research grant 573607/2008-7 (INCT, INBEQMeDI program from CNPq, FAPESP and the Ministry of Health).

\section{References}

[1] Toke O. Antimicrobial peptides: new candidates in the fight against bacterial infections. Biopolymers 2005; 80(6):717-735. 
[2] Marshall SH, Arenas G. Antimicrobial peptides: A natural alternative to chemical antibiotics and a potential for applied biotechnology. Electronic Journal of Biotechnology $2003 ; 6(3)$.

[3] Tsuberya H, Ofek I, Cohen S, Fridkin M. N-terminal modifications of Polymyxin B nonapeptide and their effect on antibacterial activity. Peptides 2001; 22: 1675-1681.

[4] Boman HG. Peptide antibiotics and their role in innate immunity. Annu. Rev. Immunol $1995 ; 13: 61-92$.

[5] Kato T, Matsuda T, Ogawa E, Ogawa H, Kato H, Doi U, Nakamura R. Plantaricin-149, a bacteriocin produced by Lactobacillus plantarum NRIC 149. Journal of Fermentation and Bioengineering 1994; 77 (3): 277-282.

[6] Muller DM, Carrasco MS, Simonetta AC, Beltramini LM, Tonarelli GG. A synthetic analog of Plantaricin 149 inhibiting food-borne pathogenic bacteria:evidence for $\boldsymbol{\alpha}$-helical conformation involved in bacteria-membrane interaction. Journal of Peptide Science 2007; 13 (3): 171-178.

[7] Lopes JLS, Nobre TM, Siano A, Humpola V, Bossolan NRS, Zaniquelli MED, Tonarelli G, Beltramini LM. Disruption of Saccharomyces cerevisiae by Plantaricin 149 and investigation of its mechanism of action with biomembrane model systems. Biochimica et Biophysica Acta (BBA) - Biomembranes 2009; 1788 (10): 2252-2258. 
[8] Castro MS, Ferreira TCG, Cilli EM, Crusca Jr E, Mendes-Giannini MJS, Sebben A, Ricart CAO, Sousa MV, Fontes W. Hylin a1, the first cytolytic peptide isolated from the arboreal South American frog Hypsiboas albopunctatus ("spotted treefrog"). Peptides 2009; 30 (2): 291-296.

[9] Leite, JRSA; Brand GD, Silva LP, Kückelhaus SAS, Bento WRC, Araújo ALT, Martins GR, Lazzari AM, Bloch Jr C. Dermaseptins from Phyllomedusa oreades and Phyllomedusa distincta: Secondary structure, antimicrobial activity, and mammalian cell toxicity. Comparative Biochemistry and Physiology- Part A 2008; 151: 336-343.

[10] Koo YS, Kim JM, Park IY, Yu BJ, Jang SA, Kim KS, Park CB, Cho JH, Kim SC. Structure-activity relations of parasin I, a histone H2A-derived antimicrobial peptide. Peptides 2008; 2 (9): 1102-1108.

[11] Zhao H, Sood R, Jutila A, Bose S, Fimland G, Nissen-Meyer J, Kinnunen PK. Interaction of the antimicrobial peptide pheromone Plantaricin A with model membranes: implications for a novel mechanism of action. Biochim Biophys Acta 2006; 1758(9): 146174.

[12] M.R. Yeaman, N.Y. Yount. Mechanisms of antimicrobial peptide action and resistance. Pharmacol Rev 2003; 55: 27-55.

[13] Sato H, Feix JB. Peptide-membrane interactions and mechanisms of membrane destruction by amphipathic $\alpha$-helical antimicrobial peptides. Biochim. Biophys. Acta 2006; 1758: $1245-1256$. 
[14] Sreerama N, Venyaminov SY, Woody RW. Estimation of protein secondary structure from circular dichroism spectra: inclusion of denatured proteins with native proteins in the analysis, Anal. Biochem 2000; 287 (2): 243-251.

[15] Otvos Jr L, Snyder C, Condie B, Bulet P, Wade J. D. Chimeric antimicrobial peptides exhibit multiple modes of action. Int. J. Pept. Res. Ther. 2005; 11: 29-42.

[16]. Zelezetsky I, Pacor S, Pag U, Papo N, Shai Y, Sahl HG, Tossi A. Controlled alteration of the shape and conformational stability of alpha-helical cell-lytic peptides: effect on mode of action and cell specificity. Biochem. J. 2005; 390: 177-188.

[17] Tagg JR, Dajani AS, Wannamaker LW. Bacteriocins of Gram-positive bacteria. Bacteriol. Rev 1976; 40: 722-756. 


\section{FIGURE LEGENDS}

Figure 1 - ESI-MS and reverse phase chromatography profile of Pln149 derived-peptides. Molecular mass of (A) Pln149(6-22), (B) Ac-Pln149(6-22), (C) Noctil-Pln149(6-22), (D) Fmoc-Pln149(6-22) are 1802, 1844, 1928 and 2024 Da, respectively. Inserts: Pln149a analog peptides on $\mathrm{C}_{18}$ column correspond to the majoritary peak. Column was equilibrated with $\mathrm{H}_{2} \mathrm{O}$ (TFA $0.1 \%$ ) and eluted in a gradient of acetonitrile 90\% (TFA $0.1 \%$ ) in 40 minutes (dotted curves), flow rate of $1 \mathrm{~mL} / \mathrm{min}$. The difference in hydrofobicity is a result of the peptide size reduction and the N-terminal modifications.

Figure 2 - Far-UV CD spectra of Pln149 analog peptides. (A) Pln149a (0.1 mg/mL) and the four analogs in aqueous solution. (B) Pln149a $(0.1 \mathrm{mg} / \mathrm{mL})$ and modified analogs in the presence of $1 \mathrm{mM}$ DPPG vesicles. Measurements were taken from 190 to $250 \mathrm{~nm}$ as the average of 8 scans, at $25^{\circ} \mathrm{C}$ and using a $0.1 \mathrm{~cm}$ pathlength quartz cuvette.

Figure 2 - Minimum Inhibitory Concentration (MIC) of Pln149 and analogs against $S$. aureus and $P$. aeruginosa. Pln149a was more effective against $S$. aureus, with the lowest MIC value f $19 \mu \mathrm{M}$, in opposition to $155 \mu \mathrm{M}$ to $P$.aeruginosa. Analogs presented lower MIC values than Pln149a. Error bars were estimated at $5 \%$. 


\section{Figure 1}

Click here to download high resolution image
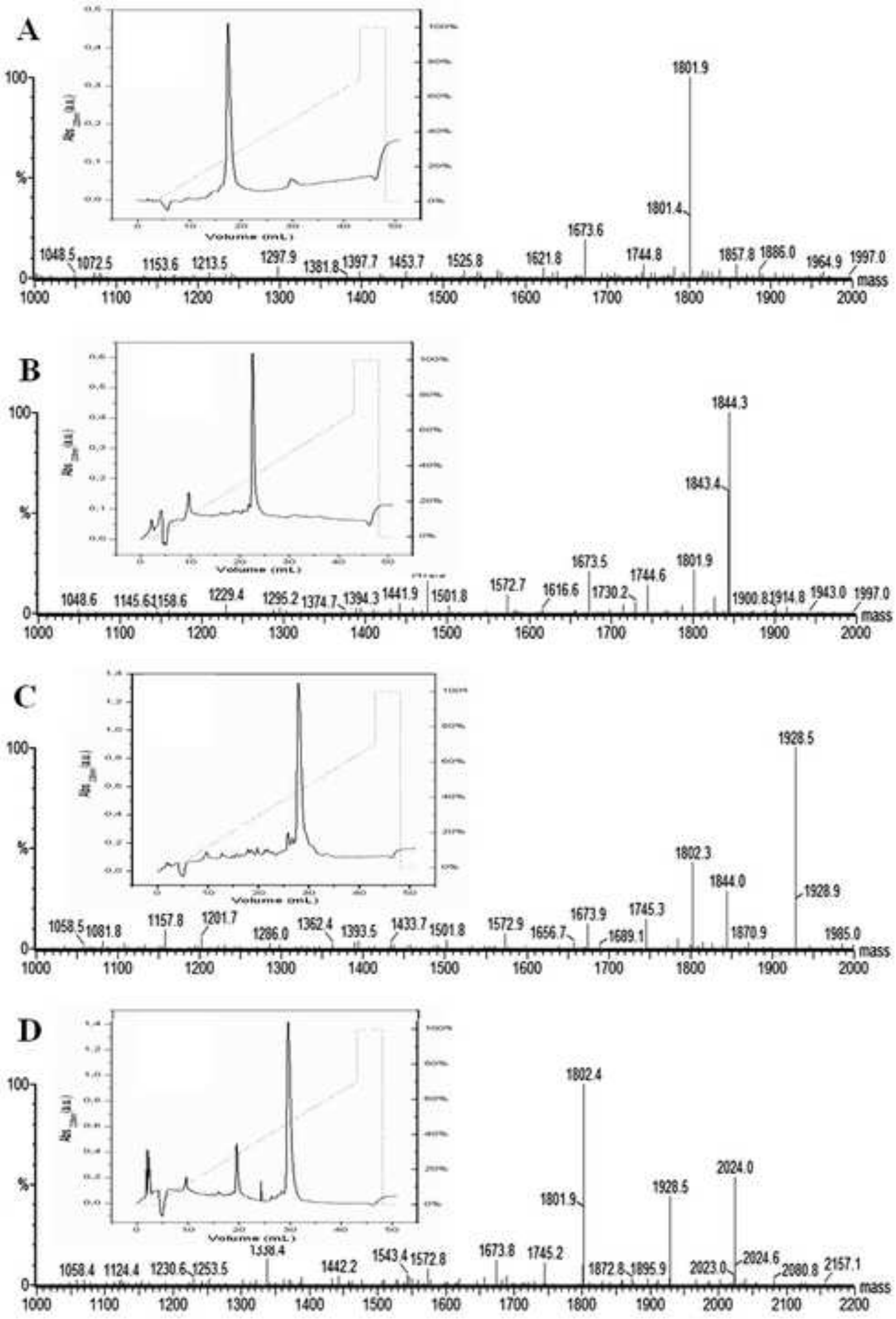
Click here to download high resolution image
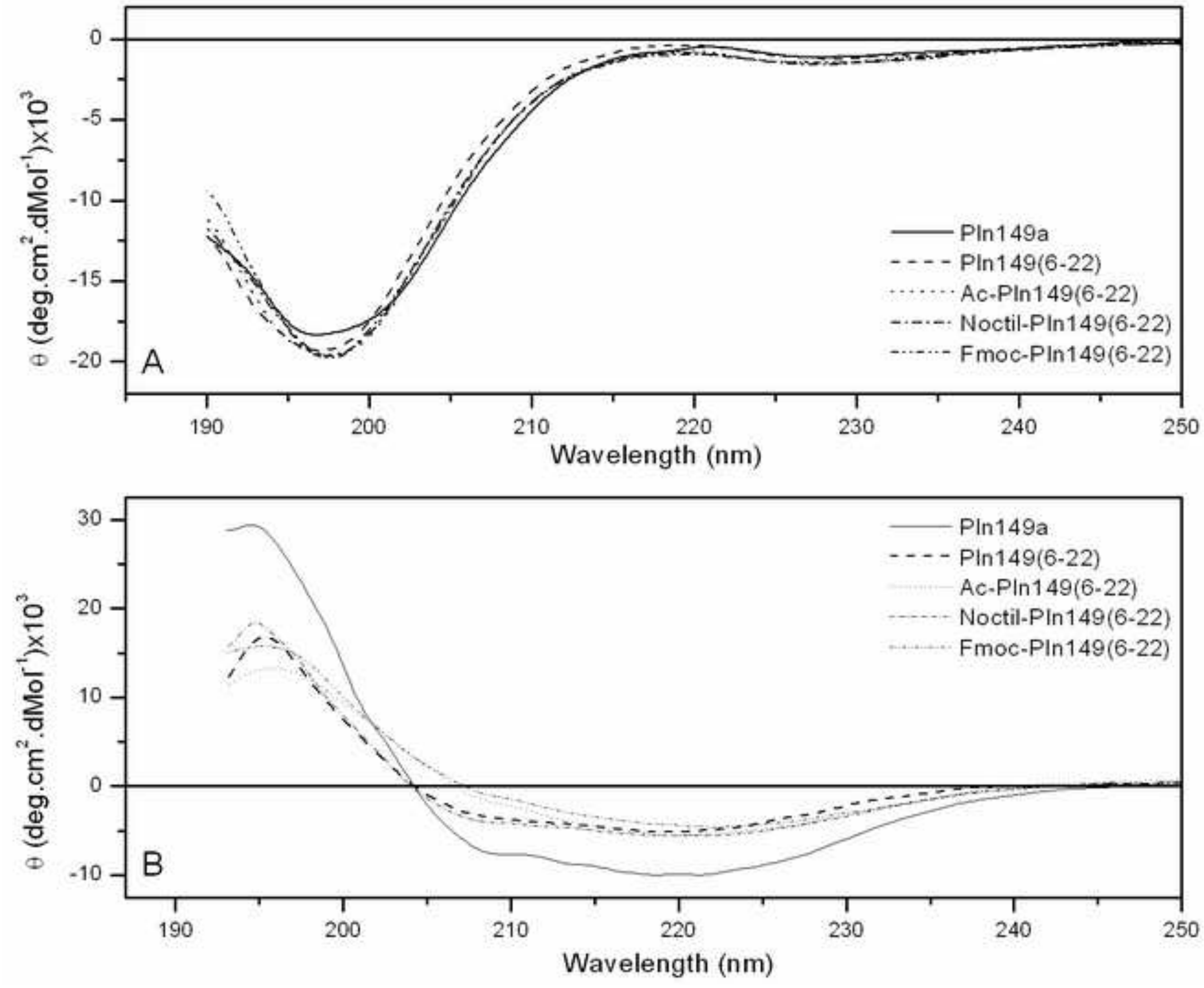


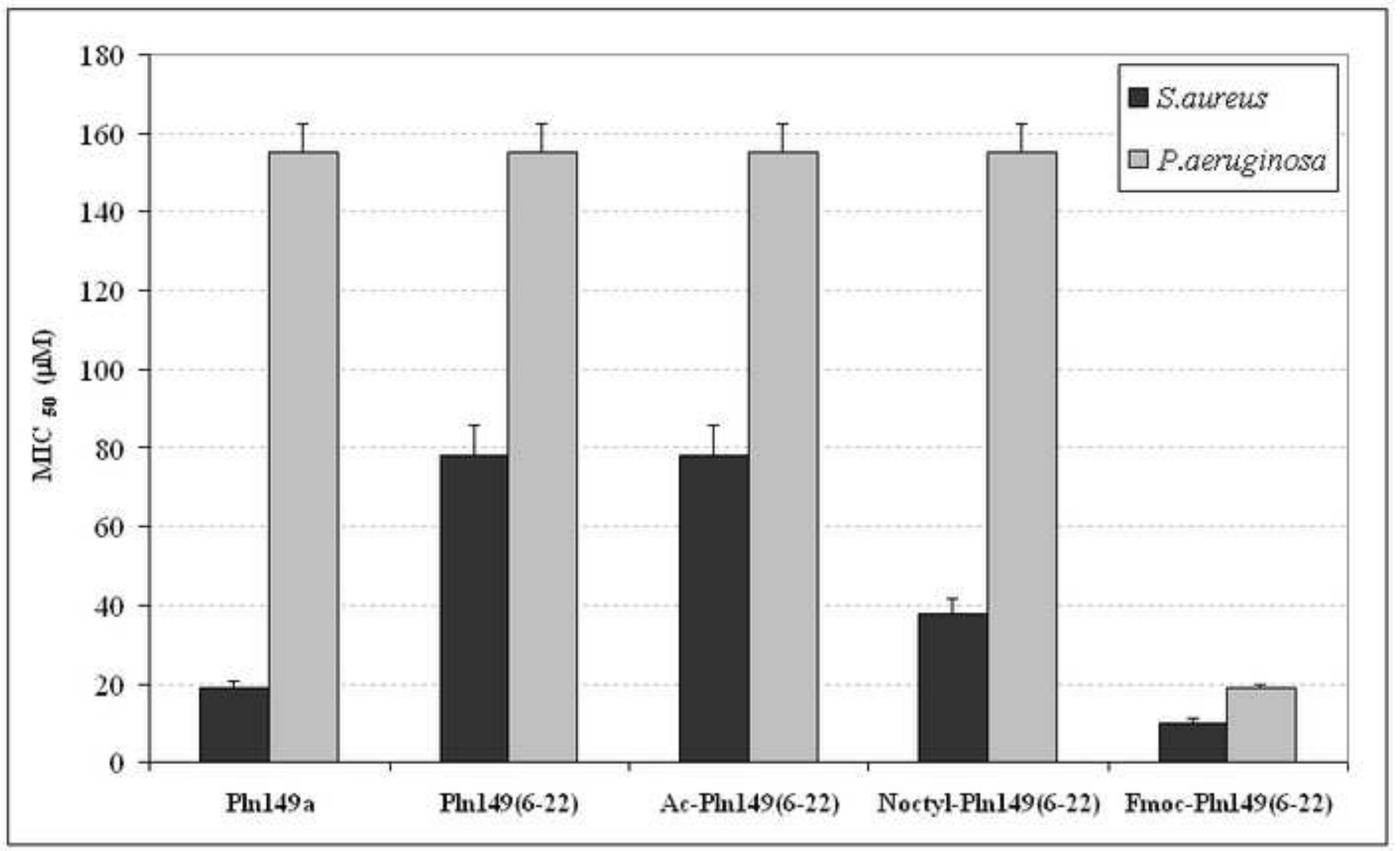


Sequences of Pln149 analogs

\begin{tabular}{lrc}
\hline Peptide & Sequence & MW (Da)* \\
\hline Pln149a & YSLQMGATAIKQVKKLFKKKGG & 2423.7 \\
Pln149(6-22) & GATAIKQVKKLFKKKGG & 1801.3 \\
Ac-Pln149(6-22) & Acetyl-GATAIKQVKKLFKKKGG & 1843.3 \\
Noctyl-Pln149(6-22) & N-octyl-GATAIKQVKKLFKKKGG & 1928.5 \\
Fmoc-Pln149(6-22) & Fmoc-GATAIKQVKKLFKKKGG & 2023.5 \\
\hline
\end{tabular}

${ }^{*} \mathrm{MW}=$ molecular weight determined by mass spectrometry 